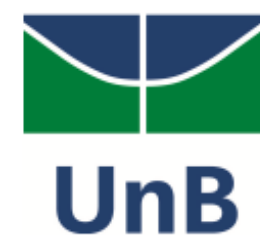

Universidade de Brasília

Faculdade de Arquitetura e Urbanismo - FAU-UnB

Programa de Pós-Graduação em Arquitetura e Urbanismo - PPG-FAU

\title{
AVALIAÇÃO DE TIPOLOGIAS CONSTRUTIVAS NOS CRITÉRIOS DE SUSTENTABILIDADE \\ Estudo de casos - Telhas
}

\section{CRISTINA GALVÃO SCHELB}

BRASÍLIA 


\section{CRISTINA GALVÃO SCHELB}

\section{AVALIAÇÃO DE TIPOLOGIAS CONSTRUTIVAS NOS CRITÉRIOS DE SUSTENTABILIDADE Estudo de casos - Telhas}

Dissertação apresentada como requisito para obtenção do título de Mestre. Curso de Mestrado na área de tecnologia e sustentabilidade. Programa de Pesquisa e Pósgraduação. Faculdade de Arquitetura e Urbanismo. Universidade de Brasília.

Orientador: Prof. Dr. Márcio Augusto Roma Buzar

\section{BRASÍLIA}




\section{UNIVERSIDADE DE BRASÍLIA}

Reitor: Ivan Marques de Toledo Camargo

\section{FACULDADE DE ARQUITETURA E URBANISMO}

Diretor: Professor José Manoel Morales Sánchez

\section{PROGRAMA DE PÓS-GRADUAÇÃO E, ARQUITETURA E URBANISMO}

Coordenador: Professor Doutor Márcio Augusto Roma Buzar

A comissão examinadora, abaixo assinada, aprova a dissertação intitulada:

"AVALIAÇÃO DE TIPOLOGIAS CONSTRUTIVAS NOS CRITÉRIOS DE SUSTENTABILIDADE: Estudo de casos - Telhas", apresentado em sessão pública por CRISTINA GALVÃO SCHELB, aluna do curso de pós-graduação em Arquitetura e Urbanismo - Área de Tecnologia da Faculdade de Arquitetura e Urbanismo de Brasília - UnB, para obtenção do grau de Mestre em Arquitetura e Urbanismo, realizado em 14 de abril 2016.

\section{Membros da Banca Examinadora: \\ Orientador:}

Professor Doutor: Márcio Augusto Roma Buzar

Faculdade de Arquitetura e Urbanismo - FAU - UnB

Examinadores:

Professor Doutor: Márcio Augusto Roma Buzar

Faculdade de Arquitetura e Urbanismo - FAU - UnB

Professor Doutor Evangelos Dimitrios Christakou

Faculdade de Engenharia Civil - ENC - UnB

Professor Doutor Janes Cleiton Alves de Oliveira

Faculdade de Engenharia Civil - ENC - UFG 
AGRADECIMENTOS

Que longa jornada...

Enfim mais um passo.

Obrigada por ser minha âncora. 
"O Homem e suas extensões constituem um sistema inter-relacionado. É um tremendo equívoco pesquisar como se o homem fosse uma coisa, sua casa e suas cidades, sua tecnologia e seu idioma fossem outras distintas."

CIRIOT, Juan E. 


\section{RESUMO}

Essa presente dissertação trata de estudo de avaliação de telhas utilizadas nas edificações brasileiras e seus aspectos sustentáveis e ecológicos. As telhas escolhidas são: telhas fotovoltaicas, telhas de tetra pak, telhas de fibra vegetal, telhas cerâmicas, telhas de garrafa pet, telhas de fibrocimento e telhas de concreto. Foi desenvolvida uma análise dessas telhas através de uma compilação e sobreposição dos selos e certificações ambientais usados no Brasil e em outros países como Estados Unidos e França. Os sistemas de avaliação e certificação da sustentabilidade de edificações tem um papel importante desde o desenvolvimento do projeto até o acabamento final da obra e a manutenção desta durante todo o seu ciclo de vida. Para que uma edificação seja considerada sustentável, devemos avaliar também o potencial do terreno, como o solo, o clima de cada região e sua identidade cultural, assim como a escolha dos materiais a serem utilizados a fim de preservar os recursos naturais e otimizar as práticas de utilização e manutenção do edifício. Desta forma, este trabalho tem como objetivo avaliar estes diferentes tipos de telhas apresentados para que profissionais da área da construção civil e arquitetura possam ter um auxílio quanto à escolha acertada do material mais sustentável.

Palavras-chave: Certificações Ambientais, Selos, Sustentabilidade, Telhas. 


\begin{abstract}
This present dissertation of shingles used in Brazilian's buildings, in their sustainable and ecological aspects. The chosen tiles are photovoltaic tiles, tiles tetra pak, vegetable fiber tiles, ceramic tiles, plastic bottle tiles, cement tiles and concrete tiles. An analysis of these tiles was developed through a compilation and overlap of environmental certifications and seals used in Brazil and other countries like the US and France. Systems assessment and certification of sustainability have an important role since the development of the project until the final finishing of the work and maintaining this throughout their life cycle. For a building to be considerated sustainable, we must also assess the land potential, such as soil, the climate of each region and their cultural identity, as well as the choice of materials to be used in order to conserve natural resources and optimize practices for use and maintenance of the building. Thus, this thesis aims to evaluate these different types of tiles for professionals in the construction industry and architecture area can be an aid as a right choice of more sustainable materials.
\end{abstract}

Keywords: Environmental, Seals, Sustainability, Roofing Tiles and certifications. 


\section{LISTA DE ILUSTRAÇÕES}

Figura 1.1 - As pessoas, os eventos, os acordos e as estratégias que construíram a trajetória global em nome da sustentabilidade................................................................. 26

Figura 1.2 - Vista Interna 1 da residência ecológica em Saplehurst, Grã-Bretanha. 28

Figura 1.3 - Vista Interna 2 da residência ecológica em Saplehurst, Grã-Bretanha. 28

Figura 1.4 - Fachada Frontal da residência ecológica em Saplehurst, Grã-Bretanha. 28

Figura 1.5 - Animação gráfica de urbanismo sustentável....................................... 31

Figura 1.6 - Animação gráfica de urbanismo sustentável........................................ 31

Figura 1.7 - Animação gráfica de urbanismo sustentável........................................... 31

Figura 1.8 - Animação gráfica de edificação sustentável. ........................................ 32

Figura 1.9 - Animação gráfica de edificação sustentável. .............................................. 32

Figura 1.10 - Animação gráfica de edificação sustentável. ........................................ 32

Figura 1.11 - Quadro de prioridades a serem consideradas no desenvolvimento de um projeto. .......................................................................................................................... 33

Figura 1.12 - Projeto residencial do arquiteto colombiano Simon Velez, localizada no sul da Bahia............................................................................................................................... 34

Figura 1.13 - Pigmentos naturais usados nas tintas ecológicas............................... 35

Figura 1.14 - Uso da madeira plástica em fachadas. Projeto de Tatiana Terry e Luciano Alvarez. Residência localizada na Serra Fluminense................................... 36

Figura 1.15 - Uso da madeira plástica em fachadas e deck. Imagem ilustrativa feita pela Madeplast. ................................................................................................................ 36

Figura 2.1 - Representação das trocas de calor de um telhado. ............................... 38

Figura 2.2 - Telha solar fabricada pela empresa Solbravo - Curitiba. .................... 39

Figura 2.3 - Telha solar fabricada pela Tegola Solare .................................................. 40

Figura 2.4 - Camada das embalagens Tetra Pak.......................................................... 41

Figura 2.5 - Telha ecológica Tetra Pak ............................................................................... 41

Figura 2.6 - Telhado de Casa com Telha Tetra Pak................................................ 41 
Figura 2.7 - Telha Tetra Pak/Telha de Fibrocimento- temperatura (conforto térmico) ......................................................................................................... 42

Figura 2.8 - Telha ecológica Onduline. .................................................................. 44

Figura 2.9 - Telha cerâmica Versatex. ............................................................................................ 45

Figura 2.10 - Telha Ecologic Lux. ......................................................................... 45

Figura 2.11 - Vogatex (Eternit) .......................................................................... 47

Figura 2.12 - Canalete 49(Eternit) ............................................................................................... 47

Figura 2.13 - Selo Procel............................................................................................................. 51

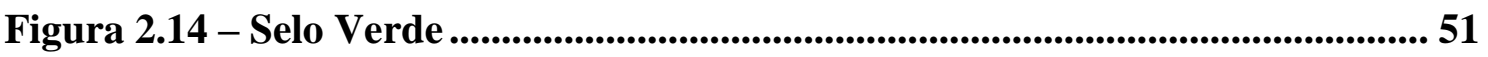

Figura 2.15 - Telhas de Concreto Coloridas............................................................................ 51

Figura 3.1 - Critérios de Avaliação - Resumo GBC/LEED.................................... 66

Figura 3.2 - Tabela de Avaliação de Critérios - LEED for homes. .......................... 68

Figura 3.3 - Critérios de Avaliação - AQUA................................................................. 70

Figura 3.4 - Perfil Mínimo de Desempenho - AQUA...................................................... 71

Figura 3.5 - Logomarca e níveis de graduação dos Selos Casa Azul: níveis ouro, prata e bronze. .............................................................................................................................................. 73

Figura 3.6 - Etiqueta de Eficiência Energética - Edifícios Comerciais, de Serviços e

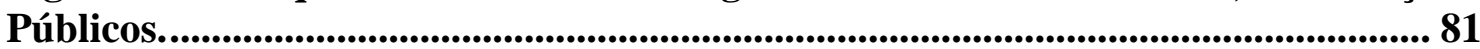

Figura 3.7 - Etiqueta de Eficiência Energética - Unidade Habitacional Autônoma. 81

Figura 3.8 - Equivalente Numérico para cada nível de Eficiência. 86

Figura 3.9 - Classificação do nível de eficiência de acordo com a pontuação obtida. 86

Figura 5.1 - Pontuação na sequência dos produtos na avaliação da sustentabilidade. 116 


\section{LISTA DE TABELAS}

Tabela 2.1 - Tabela - telhas de concreto........................................................................... 48

Tabela 2.2 - Telhas cerâmicas ...................................................................................... 49

Tabela 3.1 - Resumo BREEAM New Construction.................................................. 54

Tabela 3.2 - Categorização dos tipos de LEED no Brasil............................................. 61

Tabela 3.3 - Tipologias e abrangências do LEED Brasil.......................................... 62

Tabela 3.4 - Resumo LEED Referencial Casas................................................................. 63

Tabela 3.5 - Resumo AQUA................................................................................................. 72

Tabela 3.6 - Resumo Selo Casa Azul - Caixa.................................................................... 74

Tabela 3.7 - Tabela Resumo das Categorias, Critérios e Classificação do Selo Casa

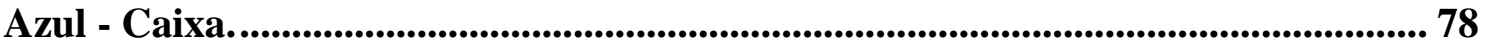

Tabela 3.8 - Tabela Resumo PROCEL Edifica ........................................................... 82

Tabela 4.1 - Comparativo entre o Referencial GBC Brasil Casa e o Selo Casa Azul Caixa (Adaptado de: GBCB, 2012 e JOHN; PRADO, 2010.). .................................. 91

Tabela 4.2 - Interação entre as cinco ferramentas de avaliação da sustentabilidade. 94

Tabela 4.3 - Critérios de Avaliação -Tipos de Telhas. ........................................... 98

Tabela 4.4 - Quadro de Classes e Pontuação....................................................................... 102

Tabela 4.5 - Método simplificado de avaliação de coberturas - tipos de telhas... 103

Tabela 4.6 - Classes das influências sobre o produto e pontuações......................... 104

Tabela 4.7 - Quadro de avaliação. ....................................................................... 106

Tabela 5.1 - Resultados do método de avaliação sustentável em sistemas de

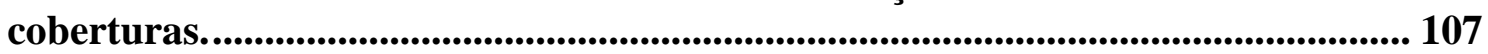

Tabela 5.2 - Resultados - Quadro de Avaliação. ..................................................... 114

Tabela 5.3 - Quadro de Avaliação - resultados em porcentagens........................... 114 


\section{LISTA DE ABREVIATURAS E SIGLAS}

\section{Abreviaturas}

Art.

- Artigo

Kwh

- Kilowatt Hora

$\mathrm{M}^{2}$

- metro quadrado

Siglas

ABNT

- Associação Brasileira de Normas Técnicas

ACVP

- Ciclo de Vida dos Produtos

AQUA

- Alta Qualidade Ambiental

BEPAC

- Building Environmental Performance Assessment Criteria

BREEAM

CCA

- Building Research Establishment Environmental Assessment Methodology

CIB

- Arseniato de Cobre Cromatado

$\mathrm{CFC}$

- Conselho Internacional da Construção

COV's

- Cloro Flúor Carbono

GBC

- Composto Orgânico Volátil

$\mathrm{HCFC}$

- Green Building Challenge

IDHEA

- Hidroclorofluorcarbono

INMETRO

- Instituto para o Desenvolvimento da Habitação Ecológica

LEED

- Instituto Nacional de Metrologia, Qualidade e Tecnologia

PBE

- Leadership in Energy and Environmental Design

PNMCB

- Programa Brasileiro de Etiquetagem de Edifício

PNRS

- Política Nacional de Resíduos Sólidos

PROCEL Edifica

- Política Nacional de Resíduos Sólidos

PVC

- Programa Nacional de Eficiência Energética em Edificações

QAE

- Policloreto de Vinila

$\mathrm{RCC}$

- Qualidade Ambiental do Edifício

SGE

- Resíduos de Construção Civil

$\mathrm{UH}$

- Sistema de Gestão do Empreendimento

WPC

- Unidade Habitacional Autônoma

- Wood Plastic Compositers 


\section{SUMÁRIO}

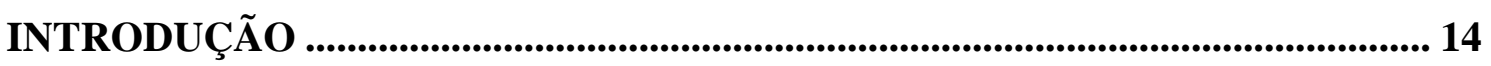

ESTRUTURA DE PESQUISA ..................................................................................... 22

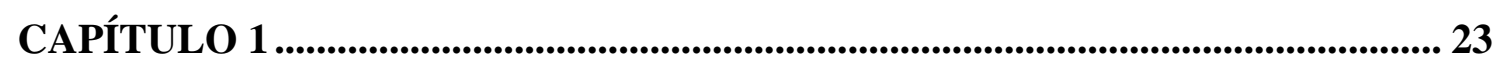

FUNDAMENTAÇÃO E OBJETIVOS: A SUSTENTABILIDADE E A CONSTRUÇÃ O CIVIL .................................................................................................... 23

1.1 Materiais sustentáveis de construção .................................................................33

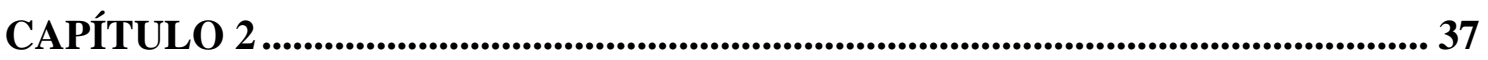

ESTUDO E LEVANTAMENTO DAS TELHAS ..................................................... 37

$2.1 \quad$ Telhas Fotovoltaicas .............................................................................................37

$2.2 \quad$ Telhas de tetra pak .........................................................................................40

2.3 Telha onduline de fibra vegetal .........................................................................43

2.4 -Telha cerâmica vasatex e telha ecologic lux - pet .............................................44

2.5 Telha de fibrocimento eternit .............................................................................46

$2.6 \quad$ Telhas de concreto tégula................................................................................47

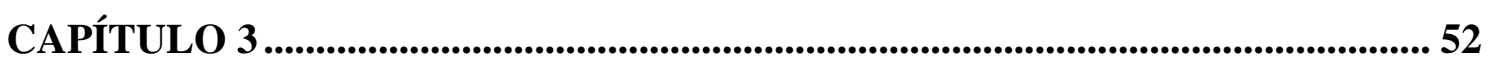

CRITÉRIOS DE AVALIAÇÃo DAS TELHAS ................................................... 52

3.1 BREEAM ........................................................................................................53

3.2 GBC e GBC Brasil ..........................................................................................57

3.3 LEED................................................................................................................59

3.4 AQUA ............................................................................................................68

3.5 Casa Azul Caixa ...............................................................................................73

3.6 PROCEL Edifica (Brasil) ...............................................................................79

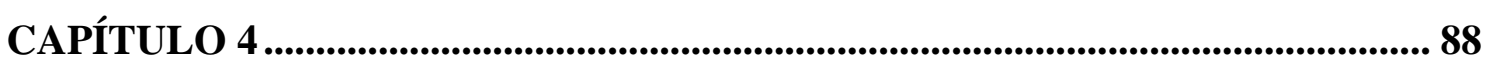

JUSTIFICATIVA DA ESCOLHA DOS SELOS ECOLÓGICOS E DAS CERTIFICAÇÕES PARA ANÁLISE DAS COBERTURAS - TIPOS DE TELHAS E ANÁLISE COMPARATIVA E SEMELHANÇA DOS SELOS E EXERCÍCIO DE AVALIAÇÃO DA SUSTENTABILIDADE PARA COBERTURAS-TIPOS DE TELHAS.................................................................................................................................... 88

4.1 Justificativa da escolha dos selos ecológicos e das certificações .........................88

4.2 Análise comparativa e semelhança dos selos..........................................................90

4.3 Exercício de avaliação da sustentabilidade para tipos de telhas .......................92

4.3.1 A Construção do Exercício .........................................................................................93 
4.3.2 Critérios de Avaliação: Tipos de Telhas ..................................................................98

4.3.3 O Exercício de Avaliação e as Ponderações .................................................102

4.4 A aplicação dos produtos no método de avaliação da sustentabilidade.........106

CAPÍTULO 5 ........................................................................................................................... 107

APLICAÇÃO, ANÁLISES E RESULTADOS ........................................................ 107

CONCLUSÃO

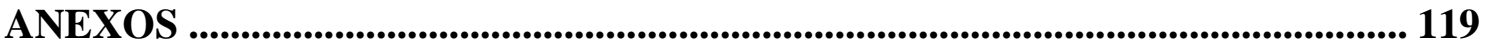

Anexo I - Certificado de Garantia: Telhas Vasatex.....................................................119

Anexo II - Certificado Madeira Legal: Intercil - empresa fabricante dos produtos Vasatex ...................................................................................................................120

Anexo III - Tipologias - Coberturas ................................................................121

Anexo IV - Propriedades Térmicas - Coberturas ..........................................................122

Anexo V - Telhas LEVE - ECCOCLEAN....................................................................123

Anexo VI - Placas Solares ................................................................................................124

Anexo VII - Placas Solares ....................................................................................................125

Anexo VIII - Projeto Tamar ....................................................................................126

Anexo IX - Certificados Telhas De Concreto Tégula .............................................127

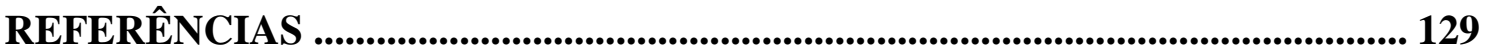




\section{INTRODUÇÃO}

O surgimento das grandes demandas ambientais impostas pela degradação do meio ambiente, vividas no último século, colocou a humanidade em uma postura mais respeitosa diante dos meios de exploração dos recursos naturais. Considerações no intuito de promover a sustentabilidade fazem parte do cotidiano de todas as profissões. Arquitetos e Urbanistas são protagonistas destas ações na medida em que a produção arquitetônica é ao mesmo tempo geração de riquezas e responsável por uma grande parcela do impacto ambiental, desde a extração de sua matéria prima como o gasto energético no uso e manutenção destes edifícios. Neste sentido, a investigação e a certificação dos selos ecológicos dos edifícios vêm sendo

perseguidas por vários profissionais envolvidos no processo da produção arquitetônica. É importante saber se as intenções projetuais se verificarão como ações certeiras na manutenção da sustentabilidade dos processos construtivos ou não. Para colaborar com esta investigação, avaliamos alguns tipos de telhas existentes no mercado, sendo algumas sustentáveis e ecológicas, conforme os fabricantes. As casas ocupam um lugar de destaque nesta avaliação, pois, tradicionalmente as residências brasileiras são edificadas por meio de sistemas construtivos pouco industrializados e com intensa atividade nos canteiros de obra. Obras com estas características são suscetíveis a elevado custo, aumento dos processos construtivos, desperdício no armazenamento e descarte dos materiais de construção.

Atualmente, há uma demanda por edificações sustentáveis no Brasil e no mundo, onde a economia e o racionamento de energia e de elementos naturais estão se tornando imprescindíveis nas elaborações de projetos e nas obras civis. Vimos que, para uma edificação ser sustentável, é necessário que solucione mais do que um problema ambiental, como o esgotamento de recursos naturais ou as emissões de carbono, deve tratar também das questões do uso adequado do terreno e seu entorno e de resíduos gerados na construção. É necessário fazer a busca da eficiência na utilização desses recursos. O setor da construção civil é um dos grandes responsáveis pelos impactos ambientais no Brasil, começando pela grande quantidade de recursos naturais e de energia utilizados na produção e transporte de matérias primas, passando pela concepção do projeto (design com preocupação exclusivamente estética, má escolha de materiais e conceitos de conforto ambiental desconsiderados) e terminam em grande volume de resíduos resultantes de técnicas de construção artesanais empregadas por uma mãode-obra desqualificada. (http://www.idhea.com.br/pdf/casa_curitiba.pdf). No caso do Brasil, a arquitetura deve ser abordada como uma arquitetura "pertinente" e "adequada" ao clima 
brasileiro. Ainda sob este aspecto, esta decisão deve ir ao encontro de arquitetura apropriada a um país tropical, predominantemente quente e úmido em algumas partes e seco em outras. Segundo Oliveira (2010), esta relação entre arquitetura e lugar deve ser resgatada após largo período de produção arquitetônica baseado em modelos universais. Algumas dessas considerações são apresentadas sobre a construção sustentável e sua avaliação ambiental.

Conforme Fernando Almeida (2002), a noção do desenvolvimento sustentável vem sendo utilizada como portadora de um novo projeto para a sociedade, capaz de garantir, no presente e no futuro, a sobrevivência dos grupos sociais e da natureza.

Os procedimentos de produção de um dado edifício, desde a tomada de decisão até a sua ocupação relaciona-se diretamente ao planejamento, gerenciamento, projetos, construção, e comercialização do edifício requisitado. É o processo pelo qual, materiais e componentes, terra, energia e combustível, água, máquinas, ferramentas e mão-de-obra são agrupados e organizados para a produção de um determinado produto: edifícios de variadas funções (residencial, comercial, industrial, hospitalar, educacional entre outros), e (ou) obras de infraestrutura (saneamento, hidroelétrica, abastecimento de água, etc.). (BLUMENSCHEIN, 2004)

Segundo Blumenschein, o processo de produção de edificações ou de obras é formado pelas seguintes etapas:

- Planejamento e análise de viabilidade do empreendimento;

- Projeto;

- Construção ou execução;

- Utilização da edificação, manutenção e reformas; e;

- Demolição quando acaba a vida útil da edificação.

Já para Araújo (2005), há nove passos principais para uma construção sustentável, são eles:

- Planejamento da obra,

- Aproveitamento passivo dos recursos naturais, 
- Eficiência energética,

- Gestão e economia da água,

- Gestão de resíduos na edificação,

- Qualidade do ar e do ambiente interior,

- Conforto térmico e acústico,

- Uso racional de matéria e

- Uso de produtos e tecnologias ambientalmente amigáveis.

Porém, não é sempre possível seguir todos esses passos em função da falta de conhecimento da metodologia adotada, de materiais de alta qualidade e novas tecnologias, além dos custos que uma construção sustentável possui. Uma arquitetura de qualidade busca harmonia entre os conceitos bioclimáticos, eficiência energética e materiais escolhidos, tomando como padrão geral a adaptabilidade ao sítio e os espaços construídos tendo onde a beleza e a praticidade caminhando juntas ao desenvolvimento ambiental, dando ênfase na preocupação que o impacto ambiental causará ao meio ambiente.

Na opinião de Silva (2003), a construção sustentável não implica em priorizar uma dimensão em detrimento das demais, nem demanda uma solução perfeita e sim a busca do equilíbrio entre a viabilidade econômica que mantém as atividades e negócios, as limitações do ambiente $\mathrm{e}$ as necessidades da sociedade.

Inicia-se então o projeto arquitetônico por meio de um estudo climático do local escolhido, com foco em amenizar as condições ambientais e aproveitar de forma mais adequada os elementos favoráveis para geração de conforto humano, permitindo uso racional e moderado dos recursos naturais e energéticos. Na elaboração do projeto arquitetônico, a edificação deve ser um elemento de controle do clima, onde o estudo de seu desempenho é importante para o direcionamento das intervenções no espaço construído, tentando reprimir os gastos energéticos excessivos como iluminação artificial e condicionamento de ar, além de gerar maior conforto térmico e acústico aos moradores. É importante selecionar materiais mais saudáveis ambientalmente para indicar nos projetos arquitetônicos, assim, a edificação será menos nociva ao meio ambiente. (OLIVEIRA 2010). 
Um item de relevância na construção sustentável citada pela Agenda 21 é a necessidade em reduzir o desperdício e gestão de resíduos, pensando na reciclagem destes no que refere a construção civil (RCC) e no aumento do uso de reciclados como materiais de construção. O uso racional da água feito com a utilização de sistemas de aproveitamento de águas pluviais, tratamento dos resíduos sólidos das águas cinzas, reaproveitamento das águas servidas e utilização de vaso sanitário seco, ajuda a evitar racionamentos causados por vazamento na rede e excessos de consumo. A racionalização de energia e o aumento da eficiência energética do setor são estudados a partir dos partidos arquitetônicos que, em relação ao conforto térmico, faz-se necessária adicionar as edificações o isolamento térmico, para manter ou excluir o calor; utilizar superfícies transparentes, para permitir a entrada da radiação solar, quando necessário; utilizar a massa térmica, para armazenar o calor e liberá-lo quando necessário; uso de elementos de sombreamento, para bloquear a entrada solar pelas superfícies transparentes; uso de aberturas para direcionar e controlar os fluxos de ar.

Apesar de não fazer parte deste trabalho, vale a pena citar como sugestão de estudo, uma solução paralela ao estudo das telhas, a cobertura vegetal, que ajuda a conferir níveis de isolamento térmico adequado à realidade climática local, através de uma camada de solo com vegetação, soma os efeitos de um significativo isolamento térmico com os de resfriamento evaporativo, evitando a ocorrência de variações significativas na temperatura da cobertura.

Pode-se utilizar também como outra alternativa, o uso de chapas metálicas recicladas incorporadas à estrutura do telhado para desempenhar o papel de barreira à radiação térmica incorporando mais uma camada de ar (isolante) entre o telhado e o forro, que reduz significativamente a transmissão de calor através da cobertura.

A indústria da construção civil, particularmente a construção, a execução e a demolição de edifícios, é a atividade de maior impacto ambiental atualmente. Há um grande esforço das agências governamentais, instituições de pesquisa e setores privados de diversos países para definir políticas que minimizem o uso de recursos não renováveis, aumentem a economia de energia e reduzam os resíduos de construção. Com as crescentes demandas ambientais, sob todas as áreas do conhecimento e de produção de riquezas, as considerações ambientais para promover a sustentabilidade estão cada vez mais fazendo parte da vida cotidiana. Neste contexto, a produção arquitetônica tem ganhado muita importância como disciplina de destaque na definição de um padrão de vida sustentável. E, como instrumento de produção arquitetônica, o projeto de arquitetura. Preocupados com os impactos prejudiciais que a construção de um 
edifício pode promover ao meio ambiente, profissionais da área de engenharia e arquitetura se empenham em julgar a pertinência das obras construídas sob os aspectos sustentáveis.

Um dos conceitos de construção sustentável (por Márcio Augusto Araújo) pode ser definido como sistema construtivo que promove alterações conscientes no entorno, de forma a atender as necessidades de edificação, habitação e uso do homem moderno, preservando o meio ambiente e os recursos naturais, garantindo qualidade de vida para as gerações atuais e futuras. A construção e o uso de edificações são as principais responsáveis pela demanda de energia e de materiais que produzem gases de efeito estufa derivados. Começa então o entendimento de que a construção sustentável não é um modelo para resolver problemas pontuais como edifícios energeticamente mais eficientes ou o entulho gerado pela obra, mas uma nova forma de pensar a própria construção e tudo que a envolve. Trata-se de um enfoque integrado da própria atividade, de uma abordagem sistêmica em busca de um novo paradigma: o de intervir no meio ambiente, preservando-o e, em escala evolutiva, recuperando-o e gerando harmonia no entorno. (ARAÚJO, 2005)

A avaliação destes edifícios produziu certificados e, por conseguinte, surgiram os métodos de avaliação e certificação de edifícios adequados às demandas ambientais. O primeiro sinal da necessidade de se avaliar o desempenho ambiental de edifícios veio exatamente com a constatação que, mesmo os países que acreditavam dominar os conceitos de projeto ecológico, não possuíam meios para verificar quão "verdes" eram de fato os seus edifícios. O que realmente foi comprovado posteriormente com a constatação de que os edifícios que foram projetados para sintetizar os conceitos de construção ecológica constantemente consumiam mais energia que aqueles construídos com práticas comuns de projeto e construção. O segundo impulso no crescimento de interesse pela avaliação ambiental de edifícios veio com o consenso entre pesquisadores e agências governamentais quanto à classificação de desempenho atrelada aos sistemas de certificação ser um dos métodos mais eficientes para elevar o nível de desempenho ambiental tanto do estoque construído quanto de novas edificações.

Realizar construções em harmonia com a natureza, com baixo impacto ambiental e com custos operacionais reduzidos, priorizando técnicas construtivas sustentáveis, matérias-primas naturais, recicláveis e de fontes renováveis, é um caminho para que as cidades se tornem mais sustentáveis. Essas preocupações com os impactos ambientais gerados pelos edifícios, durante as fases de planejamento e construção ou durante a operação, são cada vez maiores. Hoje em dia, basicamente cada país europeu - além de Estados Unidos, Canadá, Austrália, Japão e Hong 
Kong - possui um sistema de avaliação e classificação de desempenho ambiental de edifícios. (SILVA, 2003b). As circunstâncias contextuais que resultaram em sua criação são variáveis, assim como as aplicações pretendidas para estes sistemas, que vão desde ferramentas de apoio ao projeto até ferramentas de avaliação pós-ocupação. A grande maioria dos sistemas adequase melhor à avaliação de edifícios novos ou projetos. Embora não exista uma classificação formal nesse sentido, os esquemas de avaliação ambiental disponíveis podem ser divididos em duas categorias. Na primeira estão aqueles que são orientados para o mercado, ou seja, desenvolvidos para serem absorvidos por projetistas ou para receber e divulgar o reconhecimento do mercado pelos esforços dispensados para melhorar a qualidade ambiental dos projetos, execução e gerenciamento operacional. Neste caso a estrutura é simples e está atrelada a algum tipo de certificação de desempenho. Este é o caso do BREEAM (BALDWIN et al.,1990, 1998), do HK- BEAM (CENTRE OF ENVIRONMENTAL TECHNOLOGY, 1999), do LEED тм (USGBC, 1999), AQUA, CASA AZUL, PROCEL EDIFICA e do CSDB ESCALE (NIBEL et al., 2000). Já na segunda categoria, estão os esquemas de avaliação orientados para pesquisa, como o BEPAC (COLE; ROUSSEAU; THEAKER, 1993) e o seu sucessor o GBC (COLE; LARSON, 2000). Neste item em questão, a abordagem é feita com ênfase no desenvolvimento de uma metodologia mais abrangente que possa orientar novas pesquisas. Muitos desses selos internacionais verificam os recursos consumidos, as emissões de carbono e os resíduos gerados pelas edificações, bem como o conforto e a saúde das pessoas que convivem ali. Para isso, é feita uma avaliação sobre o grau de sustentabilidade dos edifícios, baseada em critérios específicos de cada selo. (SILVA, 2003).

Este sistema de avaliação e certificação da sustentabilidade de edifícios tem como principal propósito o agrupamento e a comunicação de informação para ser usado como suporte, nos principais processos de decisão que ocorrem nas diferentes fases do projeto, construção, readequação e utilização de um edifício. Desta forma, a avaliação de sustentabilidade envolve centenas de parâmetros, sendo muitos deles interdependentes e em parte contraditórios. (LANNOY, 2013)

Para Mateus (2009), as metodologias de avaliação da sustentabilidade encontram-se em constante evolução, de modo a corrigir as suas diferentes limitações. Atualmente, o principal desafio passa pelo desenvolvimento de uma metodologia sistemática que sirva de suporte à concepção de edifícios em que seja atingido o melhor balanço entre as diferentes dimensões da sustentabilidade, e que seja simultaneamente prática, transparente e suficientemente flexível para que possa ser facilmente adaptável aos diferentes tipos de edifícios e à constante evolução 
tecnológica. Contudo, nenhuma das ferramentas ou sistemas desenvolvidos até hoje são amplamente aceitos. O maior problema prende-se com a subjetividade associada ao conceito "sustentável”, motivada principalmente pelas diferenças políticas, tecnológicas, culturais, sociais e econômicas existentes, não só entre os países, mas também dentro de cada país, entre as diversas regiões. Esta situação impede que se utilize uma metodologia de avaliação da sustentabilidade fora do seu contexto de origem, sem que antes se realize um trabalho de adaptação à realidade ambiental, sociocultural e econômica do local onde se pretende realizar a avaliação.

A edificação construída revela a importância e interligação da indústria da construção, em termos de efeitos reais e potenciais, com o desenvolvimento sustentável. Vemos que hoje, o grande desafio que o setor da construção civil encara é o trabalho simultâneo entre os arquitetos e engenheiros com o desenvolvimento de produtos sustentáveis durante a totalidade do seu ciclo de vida.

\section{OBJETIVO GERAL}

Cabe a este trabalho de pesquisa, como objetivo geral, a continuidade dos estudos desenvolvidos por Lannoy (2013), no agrupamento dos selos ecológicos, porém, voltada para as telhas apresentadas ao longo desta dissertação, escolhidas dentro do mercado construtivo. A elaboração de ferramentas de aplicação de critérios de sustentabilidade também é identificada a partir da sobreposição e interação dos critérios para avaliação de construção sustentável.

\section{OBJETIVOS ESPECÍFICOS}

Como objetivos específicos, segue a continuação dos estudos levantados para materiais de acabamentos - pisos e revestimentos - utilizando a mesma metodologia de avaliação e certificação da sustentabilidade de edifícios, no entanto, serão conceituados produtos sustentáveis de outra linha de pesquisa de materiais construtivos: as telhas. A sobreposição dos critérios apresentados terá como intuito a identificação de como tais metodologias aportam as telhas referenciadas. Diante do exposto, será desenvolvida uma investigação de natureza qualitativa por meio de estudo de materiais com o uso dos selos e certificações ambientais.

O produto final deste trabalho poderá servir de objeto de pesquisa a grupos de profissionais da área da construção civil a fim de promover uma maior interação dos tipos de 
telhas ecologicamente corretas, tendo a intenção de apresentar uma análise sucinta da seleção das mesmas.

Este trabalho enquadra-se num projeto investigativo sobre diferentes tipos de telhas e seus aspectos ecológicos e tem como proposta final, o seu uso na construção civil. Esta investigação será feita por meio de pesquisa comparativa e conceitual tanto dos selos ecológicos quanto das telhas escolhidas. O principal objetivo é o levantamento dos critérios das ferramentas de avaliação da sustentabilidade e a compilação dos atributos nos aspectos relacionados às telhas.

A apresentação e desenvolvimento dos temas relacionados nesta presente dissertação estão divididos em seis capítulos. Nos parágrafos seguintes, serão resumidos os conteúdos contidos em cada um.

No Capítulo 1, realiza-se a introdução ao tema com uma abordagem histórica, mostrando a relevância sobre a discussão do impacto ambiental da indústria da construção civil. Tem-se como base, a literatura específica a fim de exemplificar e contextualizar o tema.

O Capítulo 2 mostra o levantamento dos tipos de telhas a serem estudados, especificando e exemplificando cada um, para que se possa mais adiante, pontuar as mais apropriadas à redução do impacto ambiental.

No Capítulo 3, é realizada a apresentação de alguns dos sistemas que têm sido mais utilizados na avaliação da sustentabilidade na construção, principalmente na área habitacional. Esta parte constitui a base do desenvolvimento da metodologia de avaliação da sustentabilidade apresentada e engloba, entre outros, a apresentação das principais metodologias de avaliação e certificação da sustentabilidade de edifícios que são utilizadas internacionalmente. É neste capítulo que estudamos os critérios de avaliação das telhas.

No capítulo 4, justificamos a escolha de cada selo ecológico e certificações para análise das telhas selecionadas e, após compilação das certificações e selos de avaliação da sustentabilidade, uma análise comparativa destes selos e das telhas, tendo como fator final o exercício onde mostra os critérios adotados.

No Capítulo 5, teremos os resultados da aplicação das telhas selecionadas no exercício de avaliação de sustentabilidade e apresentamos a conclusão da dissertação. 
ESTRUTURA DE PESQUISA

\section{O PROBLEMA}

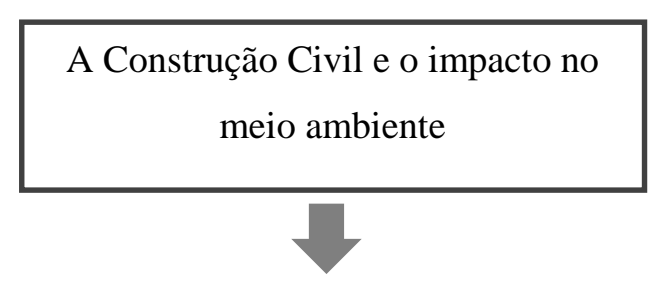

CRITÉRIOS DE ANÁLISE

O TEMA

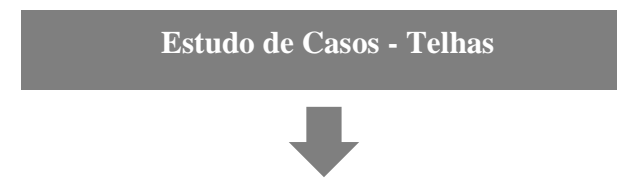

\section{PONTO DE ANÁLISE}
Avaliação da Sustentabilidade das
telhas na Construção Civil em

relação ao meio ambiente

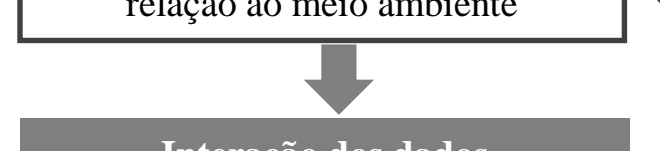

\section{Interação dos dados}
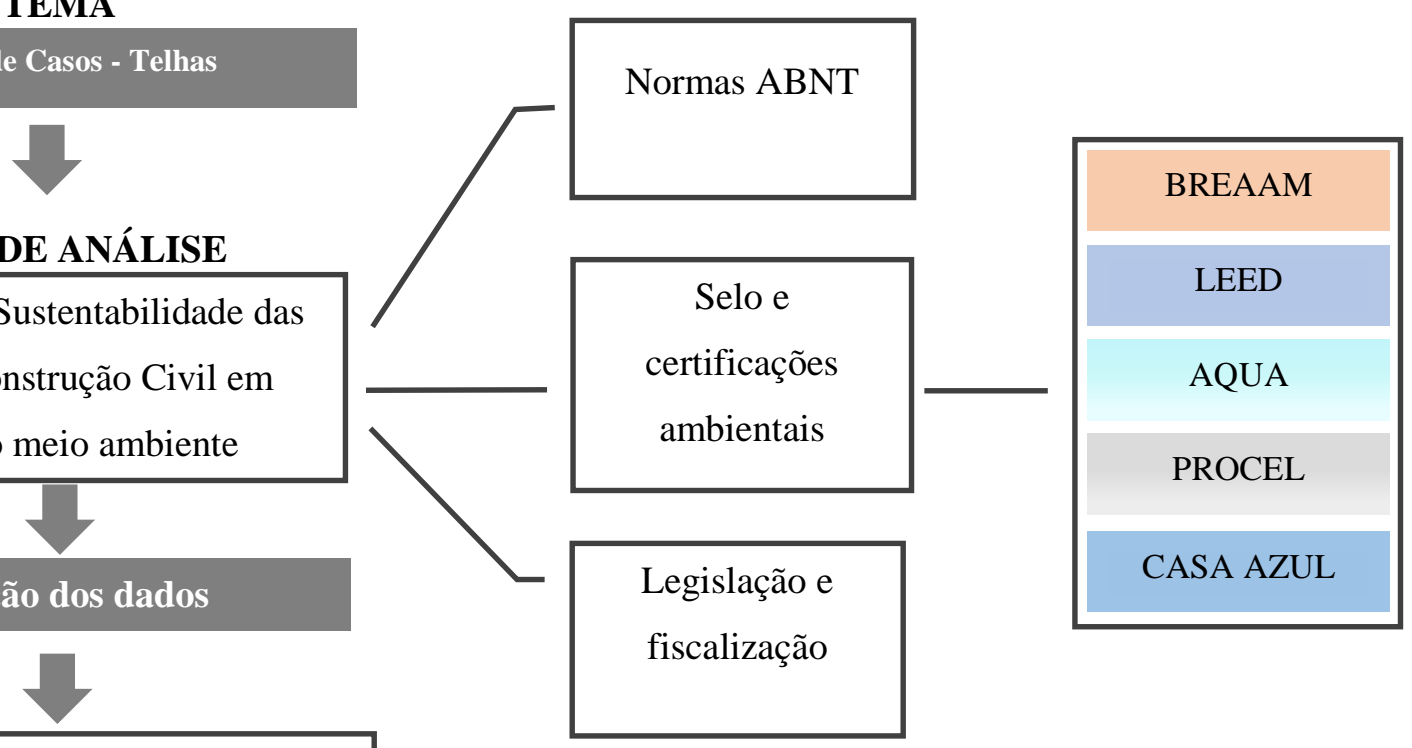

Exercícios de avaliação

\section{VERIFICAÇÃO}

Aplicação dos produtos no exercício

TABELA

Resultados 


\section{CAPÍTULO 1}

\section{FUNDAMENTAÇÃO E OBJETIVOS: A SUSTENTABILIDADE E A CONSTRUÇÃO CIVIL}

Atualmente, a construção civil vem vivendo uma época em que a atenção com as demandas da sociedade na qual está inserida tem um crescente apelo sustentável. O cuidado com o meio ambiente está ocupando, gradativamente, cada vez mais espaço nas preocupações de técnicos da área de construção civil no país e no mundo e de seus dirigentes.

Sabemos que a interferência do homem na natureza dá-se desde o neolítico, quando era retirado dela o seu sustento e seu conforto material.

No livro “A Civilização do Ocidente Medieval”, de Jacques Le Goff - 1995: “[...] Mas esta exploração devastadora do espaço era também destruidora de riquezas. Ora, o homem era então incapaz de reconstruir as riquezas naturais que destruía, ou incapaz de esperar que se reconstituíssem naturalmente".

Segundo Mateus (2009), a aplicação de práticas mais sustentáveis na construção, nomeadamente mais compatíveis com a dimensão ambiental, não é recente. Existem indícios documentados, que remontam à Antiguidade Clássica, onde se referem às ligações entre os meios natural e artificial. Este conceito foi abordado pelo arquiteto e engenheiro romano Vitrúvio (séc. I a. C.), no seu tratado de arquitetura, através de certas recomendações acerca de temas como a localização, orientação e iluminação natural dos edifícios.

Mas foi a partir de meados do século XX que começaram as interações entre economia, ambiente e bem-estar social. Os primórdios das discussões sobre questões ambientais vieram com as conversas sobre a questão da energia, impulsionadas pela falta do petróleo. Durante a Conferência das Nações Unidas sobre o Homem e o Meio Ambiente que aconteceu em Estocolmo em 1972, ficou claro que, além do desenvolvimento econômico, era necessário dar ênfase à questão ambiental, principalmente na temática "construção civil", que também esteve presente em duas outras conferências das Nações Unidas, uma no Rio de Janeiro em 1992, e a outra em Johanesburgo, em 2002. Mas foi na conferência do Rio de Janeiro (RIO 92) que o conceito de "construção sustentável" ganhou atenção. Foi ali que se desenvolveu o conceito de uma nova estratégia ambiental, na qual seu direcionamento era adaptar as recentes construções ao meio ambiente, como pode ser observado na Figura 1.1 que apresenta uma trajetória global no que se refere à sustentabilidade. 
Sendo assim, foram elaboradas as orientações para estratégias locais e nacionais na construção e foi enfatizada a constatação que, se por um lado se assistia ao crescimento exponencial do consumo energético no setor dos edifícios, por outro continuava a assistir à falta de adequação da arquitetura ou do projeto dos edifícios e do desenho e planejamento urbano às condições climáticas locais. (MATEUS, 2009)

Mantendo o raciocínio, Blumenschein (2004) constata:

Se de um lado a Cadeia Produtiva da Indústria da Construção (CPIC) causa impacto
negativo no meio ambiente, por outro ela possui um importante papel na economia e
no desenvolvimento social.
O produto principal desta cadeia é resultado de um processo complexo de produção,
que envolve um grande número de agentes. (p.10).

Desta forma, estabelece-se o paradoxo do crescimento econômico e da consequente degradação ambiental. Estatísticas apontam que em centros urbanos com mais de 500.000 habitantes, os processos construtivos são responsáveis por $40 \%$ a $70 \%$ do volume dos resíduos sólidos urbanos. Dificultando mais ainda esta situação, a tradicional teoria econômica tende a valorizar monetariamente os recursos escassos, o que gera um grande conflito com a visão ecológica. (BLUMENSCHEIN, 2004)

Na figura abaixo, tem-se um cronograma das pessoas, eventos, acordos e estratégias que construíram a trajetória global em nome da sustentabilidade.

\begin{tabular}{|c|c|}
\hline \multicolumn{2}{|c|}{ TRAJETÓRIA GLOBAL EM NOME DA SUSTENTABILIDADE } \\
\hline $\begin{array}{l}1962 \text { - O livro Silent Spring (Primavera } \\
\text { Silenciosa), da investigadora americana Rachel } \\
\text { Carson, desafia o governo americano e os } \\
\text { agrônomos ao apresentar os perigos do uso } \\
\text { indevido de pesticidas. }\end{array}$ & $\begin{array}{l}1985 \text { - Cientistas americanos e ingleses } \\
\text { descobrem o braço na camada de ozônio sobre } \\
\text { a Antártica. }\end{array}$ \\
\hline $\begin{array}{l}\mathbf{1 9 6 8} \text { - Na conferência intergovernamental para } \\
\text { uso racional e conservação da Biosfera, } \\
\text { promovida pela UNESCO, surgem as primeiras } \\
\text { discussões acerca do desenvolvimento } \\
\text { ecologicamente sustentável. }\end{array}$ & $\begin{array}{l}1986 \text { - Acidente nuclear de Chernobyl, } \\
\text { Ucrânia, ex URS. A cidade é evacuada e uma } \\
\text { poeira radioativa cobre a Europa. É relançada a } \\
\text { discussão acerca das fontes energéticas. }\end{array}$ \\
\hline $\begin{array}{l}\text { 1969 - É criada nos EUA a O.N.G. "Amigos da } \\
\text { Terra" que tem como objetivos a preservação da } \\
\text { degradação do meio ambiente, preservação da }\end{array}$ & $\begin{array}{l}1987 \text { - Publicação do relatório "Nosso Futuro } \\
\text { Comum" ou relatório de "Brundtland" pela } \\
\text { Comissão Mundial sobre o meio Ambiente e }\end{array}$ \\
\hline
\end{tabular}




\begin{tabular}{|c|c|}
\hline $\begin{array}{l}\text { biodiversidade e salvaguardar a participação } \\
\text { dos cidadãos nas tomadas de decisão. }\end{array}$ & $\begin{array}{l}\text { desenvolvimento, que cria e define pela } \\
\text { primeira vez o conceito "Desenvolvimento } \\
\text { Sustentável". }\end{array}$ \\
\hline $\begin{array}{l}1970 \text { - É comemorado o primeiro dia da terra } \\
\text { nos EUA. Reúne cerca de } 20 \text { milhões de pessoas } \\
\text { em manifestações pacíficas pela defesa do meio } \\
\text { ambiente. }\end{array}$ & $\begin{array}{l}1988 \text { - O seringueiro e sindicalista Chico } \\
\text { Mendes, que lutava contra a destruição da } \\
\text { floresta amazônica, é assassinado. Os } \\
\text { investigadores passam a estudar e alertar a } \\
\text { comunidade, através de imagens de satélites, } \\
\text { para a destruição acelerada a que este pulmão } \\
\text { mundial tem sido submetido. No mesmo ano é } \\
\text { estabelecido o painel Intergovernamental sobre } \\
\text { a Mudança Climática (IPCC), para avaliar as } \\
\text { informações científicas, técnicas e sócio- } \\
\text { econômicas mais atualizadas sobre o assunto. }\end{array}$ \\
\hline $\begin{array}{l}\text { 1971 - É criada no Canadá a famosa O.N.G. } \\
\text { "Greenpeace" como uma agenda agressiva } \\
\text { contra os impactos ambientais. No mesmo ano, } \\
\text { o investigador René Dubos e a economista } \\
\text { Barbara Ward lançam o livro "Uma Terra } \\
\text { Somente", sobre o impacto da atividade } \\
\text { humana na biosfera. }\end{array}$ & $\begin{array}{l}1992 \text { - Tem lugar no Rio de Janeiro a } \\
\text { Conferência das Nações Unidas para o Meio } \\
\text { Ambiente e desenvolvimento (Unced), a Eco- } \\
\text { 92. Dela resulta a Agenda 21, que estabelece um } \\
\text { novo padrão de desenvolvimento ambiental. } \\
\text { Também são assinadas a Convenção da } \\
\text { Biodiversidade e a Convenção de Mudanças } \\
\text { Climáticas. }\end{array}$ \\
\hline $\begin{array}{l}1972 \text { - A Conferência das Nações Unidas sobre } \\
\text { o Ambiente Humano realizada em Estocolmo, } \\
\text { na Suécia, leva à criação do Programa das } \\
\text { Nações Unidas para o Meio Ambiente } \\
\text { (U.N.E.P.). No mesmo ano, a organização } \\
\text { internacional "Clube de Roma" que discute os } \\
\text { problemas mundiais lança o polémico livro } \\
\text { "limites do Crescimento", que prevê } \\
\text { consequências desastrosas se o ritmo de } \\
\text { crescimento dos países ricos não for } \\
\text { desacelerado. }\end{array}$ & $\begin{array}{l}1994 \text { - Charles Kubert define pela primeira vez } \\
\text { o conceito de "construção sustentável" como a } \\
\text { criação e manutenção responsáveis de um } \\
\text { ambiente construído saudável, baseado na } \\
\text { utilização eficiente de recursos e em princípios } \\
\text { ecológicos. }\end{array}$ \\
\hline $\begin{array}{l}1973 \text { - Tem início a crise petrolífera que viria a } \\
\text { impulsionar o debate acerca dos limites do }\end{array}$ & $\begin{array}{l}1996 \text { - A Assembleia Geral da ONU estabelece } \\
\text { os objetivos de desenvolvimento do Milênio. }\end{array}$ \\
\hline
\end{tabular}




\begin{tabular}{|c|c|}
\hline $\begin{array}{l}\text { crescimento econômico e a utilização eficiente } \\
\text { dos recursos energéticos. }\end{array}$ & \\
\hline $\begin{array}{l}1978 \text { - O superpetroleiro Amoco Cadiz } \\
\text { naufraga e derrama } 227 \text { mil toneladas de crude } \\
\text { no mar da costa francesa. É o maior } \\
\text { derramamento de petróleo da história. No } \\
\text { mesmo ano a OCDE relança a investigação das } \\
\text { ligações entre o desenvolvimento econômico e } \\
\text { o ambiente. }\end{array}$ & $\begin{array}{l}2000 \text { - A norma ISSO } 14001 \text { é adotada como } \\
\text { padrão internacional para a gestão ambiental de } \\
\text { empresas. }\end{array}$ \\
\hline $\begin{array}{l}1980 \text { - O relatório Global 2000, encomendado } \\
\text { pelo presidente dos EUA Jimmy Carter, afirma } \\
\text { pela primeira vez que a biodiversidade é } \\
\text { fundamental para o funcionamento do } \\
\text { ecossistema planetário. }\end{array}$ & $\begin{array}{l}2005 \text { - O Protocolo de Quioto entra em vigor, } \\
\text { obrigando países desenvolvidos a reduzir a } \\
\text { emissão de gases que provocam o efeito de } \\
\text { estufa e estabelecendo o Mecanismo de } \\
\text { Desenvolvimento Limpo para os países em } \\
\text { desenvolvimento. }\end{array}$ \\
\hline $\begin{array}{l}1982 \text { - A Carta Mundial para a Natureza das } \\
\text { Nações Unidas adota o princípio de que os } \\
\text { ecossistemas e organismos devem ser geridos } \\
\text { de modo a manter uma produtividade } \\
\text { sustentável. }\end{array}$ & $\begin{array}{l}2007 \text { - O painel Intergovernamental sobre a } \\
\text { Mudança Climática (IPCC) divulga o relatório } \\
\text { mais dramático sobre o aquecimento global até } \\
\text { 2100. O filme Uma Verdade Inconveniente, } \\
\text { dirigido por Davis Guggenhem e protagonizado }\end{array}$ \\
\hline $\begin{array}{l}1984 \text { - A conferência internacional "Ambiente } \\
\text { e Economia" promovida pela OCDE concluem } \\
\text { que o ambiente e a economia são } \\
\text { interdependentes. Nesta conferência foram } \\
\text { lançadas as bases para o relatório "Nosso } \\
\text { Futuro Comum". }\end{array}$ & $\begin{array}{l}\text { pelo ex-presidente dos EUA, Al Gore, ganha } \\
\text { Oscar de melhor documentário. O IPPC e Al } \\
\text { Gore são galardoados com o Prêmio Nobel da } \\
\text { Paz. }\end{array}$ \\
\hline
\end{tabular}

Figura 1.1 - As pessoas, os eventos, os acordos e as estratégias que construíram a trajetória global em nome da sustentabilidade

Fonte: MATEUS, 2009.

O setor da construção civil tem papel fundamental para a realização dos objetivos globais do desenvolvimento sustentável. O Conselho Internacional da Construção - CIB aponta a indústria da construção como o setor de atividades humanas que mais consome recursos naturais e utiliza energia de forma intensiva, gerando consideráveis impactos ambientais. Além dos impactos relacionados ao consumo de matéria e energia, há aqueles associados à geração de resíduos sólidos, líquidos e gasosos. Estima-se que mais de 50\% dos resíduos sólidos gerados pelo conjunto das atividades humanas sejam provenientes da construção. Tais aspectos 
ambientais, somados à qualidade de vida que o ambiente construído proporciona, sintetizam as relações entre construção e meio ambiente, sendo estes considerados os maiores consumidores de recursos, energia e materiais do planeta. Como exemplo, Keeler e Burke (2010) citam que nos Estados Unidos, as edificações respondem por $48 \%$ do consumo total de energia e $73,1 \%$ do consumo de eletricidade. Elas são responsáveis por 30\% das emissões de gases de efeito estufa e consomem $12 \%$ da água potável do país.

$\mathrm{Na}$ eterna busca de minimizar os impactos ambientais provocados pela construção, aparece o paradigma da construção sustentável. No âmbito da Agenda 21 para a construção sustentável em países em desenvolvimento, tem sua definição como: "um processo holístico que aspira a restauração e manutenção da harmonia entre os ambientes natural e construído, e a criação de assentamentos que afirmem a dignidade humana e encorajem a equidade econômica".

Este terno "construção sustentável" é o que melhor expressa os aspectos ambientais, econômicos e socioculturais de um edifício no contexto da sua comunidade (KIBERT, 2005).

Para Mateus (2009), no contex to do desenvolvimento sustentável, o conceito transcende a sustentabilidade ambiental para abraçar a sustentabilidade econômica e social, que enfatiza a adição de valor à qualidade de vida dos indivíduos e das comunidades. A construção sustentável é a resposta do mercado da construção às metas e objetivos definidos para o desenvolvimento sustentável. O desenvolvimento sustentável foi até agora definido de diferentes modos, mas a definição mais consensual é aquela que consta no Relatório de Brundtland (WCED, 1987): “entende-se por desenvolvimento sustentável o desenvolvimento que satisfaz as necessidades do presente sem comprometer a possibilidade de gerações do futuro satisfazerem suas próprias necessidades".

Os desafios para a indústria da construção civil são diversos, porém, em suma, consistem na redução e aprimoramento do consumo de materiais e energia, na redução dos resíduos gerados, na preservação do ambiente natural e na melhoria da qualidade do ambiente construído. Para tanto, é necessário mudar os conceitos da arquitetura convencional na direção de projetos flexíveis com possibilidade de readequação para futuras mudanças de uso e atendimento de novas necessidades, como a redução das demolições, buscando soluções que potencializem o uso racional de energia ou de energias renováveis e propiciando a gestão ecológica da água. Reduzir o uso de materiais com alto impacto ambiental e dos resíduos da 
construção, utilizar modulação de componentes para diminuir perdas e especificações que permitam a reutilização de materiais são outros desafios a serem seguidos. Além disso, a construção e o gerenciamento do ambiente devem ser encarados dentro da perspectiva de ciclo de vida.

Usando o recurso de construção sustentável, arquitetos da Universidade de Cambridge na Grã-Bretanha apresentaram uma casa de carbono zero. Com o design econômico e de fácil construção, a casa é em forma de arco, sendo basicamente uma câmara de 20 metros coberta com vegetação. O interessante é a adaptação de uma técnica medieval que utiliza tijolos finos para criar construções leves e duráveis, conforme figuras 1.2, 1.3 e 1.4 abaixo:

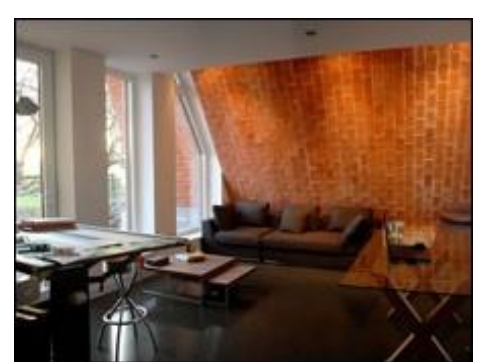

Figura 1.2 - Vista Interna $1 \mathrm{da}$ residência ecológica em Saplehurst, Grã-Bretanha.

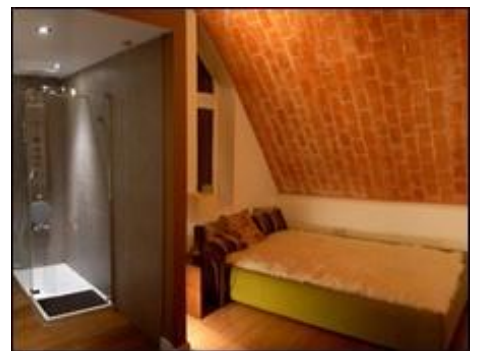

Figura 1.3 - Vista Interna 2 da residência ecológica em Saplehurst, Grã-Bretanha.

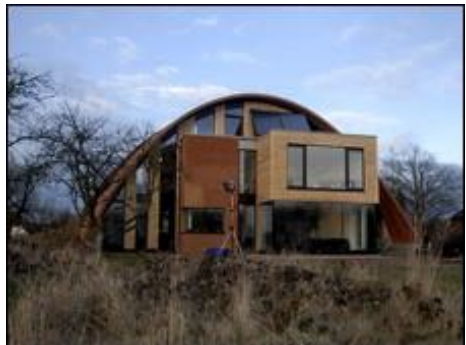

Figura 1.4 - Fachada Frontal da residência ecológica em Saplehurst, Grã-Bretanha.

Disponível em: <http://www.bbc.co.uk/portuguese/noticias/2009/02/090218_casaverde_aw.shtml〉. Acesso em 17 set. 2014.

Desta maneira, a casa adquire resistência estrutural e, ao mesmo tempo, evita a utilização de materiais que consomem muita energia na sua produção, como o concreto armado. Sua estrutura também propicia uma grande quantidade de massa térmica, permitindo que a casa retenha calor e absorva flutuações de temperatura, reduzindo assim o uso de sistemas de aquecimento e resfriamento. É utilizado também como isolante térmico, o jornal reciclado. “A construção mostra como o design contemporâneo pode promover materiais locais e integrar novas tecnologias para produzir um prédio altamente autossustentável", informa o arquiteto responsável pelo projeto, Richard Howkes.

O Ministério do Meio Ambiente em sua página mma.gov.br, nos mostra pesquisas que as tendências atuais em relação ao tema da construção sustentável caminham em duas vertentes. Por um lado, os centros de pesquisa em tecnologias alternativas pregam o resgate de materiais e tecnologias vernáculas com o uso da terra crua, da palha, da pedra, do bambu, dentre outros materiais naturais e pouco processados a serem organizados em eco vilas e comunidades alternativas. Por outro, empresários apostam em "empreendimentos verdes", com as certificações, tanto no âmbito da edificação quanto no âmbito do urbano. Porém, vários 
edifícios rotulados como verdes refletem apenas esforços para reduzir a energia incorporada e são, em muitos outros aspectos, convencionais, tanto na aparência quanto no processo construtivo. Além disso, faz-se necessário o questionamento sobre os benefícios que um selo desenvolvido para outra realidade pode trazer, especialmente para países como o Brasil que ainda não resolveram seus problemas mais básicos como pobreza e desigualdade social.

Dentro da nossa realidade, a Constituição Federal de 1988 tenta, sem muito sucesso, conciliar o desenvolvimento econômico e preservação ambiental, estabelecendo no Art. 255 que todos têm direito ao meio ambiente ecologicamente equilibrado, impondo-se ao Poder Público e à coletividade o dever de defendê-lo para as gerações presente e futuras, o que não acontece na prática. O governo brasileiro hoje possui grande potencial de atuação na temática das construções sustentáveis. Podem ser introduzidas e fomentadas boas práticas por meio da legislação urbanística e código de edificações, criando incentivos tributários e convênios com as concessionárias dos serviços públicos de água, esgoto e energia. Porém, nem mesmo as nossas leis ambientais trazem medidas consideráveis para a opinião dos ambientalistas que estão de forma constante com a bandeira que defende a natureza nas mãos.

Segundo Lannoy (2013), a agilidade no processo de elaboração e implementação de Leis Federais que regulamentem o uso consciente dos recursos naturais e os produtos que refletem essa preocupação seriam de fundamental importância para o sucesso dessas medidas. É o que se tem buscado no campo da construção com a etiquetagem de edifícios, a exemplo do que já acontece de maneira eficaz nos eletrodomésticos e lâmpadas através dos selos do INMETRO e do PROCEL.

Estudando o meio ambiente (meioambiente.culturamix.com), vimos que no Brasil, grande parte do meio urbano não possui traços sustentáveis ainda. Esse desordenamento vem desde a segunda metade do século XX, quando ainda não havia preocupação com a maneira qualificada com os conceitos de sustentabilidade. O Brasil, país que deveria ser o líder em busca de maior sustentabilidade por ser detentor das maiores riquezas tropicais do mundo, está longe de ser considero como nação sustentável.

Pesquisas feitas mostram que há um aumento de cerca de $5 \%$ nos gastos no processo de construção caso sejam feitos investimentos em sustentabilidade, contudo, a economia a médio e longo prazo, que gira em torno de $30 \%$ nos gastos com água e energia, compensa os gastos 
extras. Esses gastos a mais na construção civil assustam os empreendedores e proprietários que não conseguem visualizar a economia das edificações ao longo dos anos. (BEZERRA NETO).

Para contribuir com tais iniciativas, o EIA (Estudo de Impacto Ambiental - BA) constatou alguns princípios básicos como a formação de um conjunto de prescrições adequadas à realidade brasileira abrangendo aspectos urbanísticos e edilícios. Para o urbanismo sustentável, recomenda-se: adaptação à topografia local, com redução da movimentação de terra; preservação de espécies nativas; previsão de ruas e caminhos que privilegiem o pedestre e o ciclista, buscando mantê-las limpas, seguras, arborizadas e com pouco ruído, tendo calçadas amplas, com iluminação adequada e que contemplem a acessibilidade universal; previsão de espaços de uso comum para integração da comunidade, tendo nesse conceito, a busca do uso combinado e mútuo das diversas funções da cidade, como moradia, comércio, escritórios, lazer e educação, no mesmo espaço; e, preferencialmente, de usos do solo diversificados, minimizando os deslocamentos, reduzindo engarrafamentos, poluição, estresse e melhorando a qualidade de vida dos habitantes. Neste último princípio, observamos no quesito "transporte" analisado para qualificar os materiais de construção, principalmente as telhas, objeto deste estudo.

Quando falamos em uma cidade sustentável, devemos citar o convívio de pessoas de diferentes classes sociais, idades, culturas e raças, criando uma diversidade de moradores. Desta forma, promove-se uma variedade de ideias e necessidades que ampliam as alternativas de relacionamentos e viabilizam inúmeros aspectos da vida urbana com qualidade social. O cuidado com a densidade e a concentração de pessoas na cidade é de suma relevância para a preservação ambiental, já que proporciona um melhor desempenho energético, reduz a emissão de gases nocivos, otimiza o transporte público e as redes de água, energia e telefone, além de reduzir o uso de terrenos com edificações. Segundo esse conceito, a densidade ideal seria entre 400 a 800 habitantes por hectare.

Ainda sobre os aspectos urbanísticos, a utilização de luz natural, ar fresco e limpo circulando pelas construções convenientemente dispostas entre ruas, parques e praças traz uma harmonia entre natureza e amenidades urbanas. Estes aspectos urbanos devem ser estudados ainda na concepção do projeto. O planejamento prévio traz o equilíbrio entre áreas verdes e áreas construídas, mantendo o sombreamento com árvores ao longo das calçadas proporciona conforto e contemplação, evitando as ilhas de calor. O modelo de urbanismo sustentável preza pela construção de edificações projetadas e erguidas com o emprego de materiais e técnicas 
(Figuras 1.5, 1.6 e 1.7) que reduzem o impacto ambiental, o consumo de energia e a geração de gases do efeito estufa, tendo como exemplo as figuras abaixo.

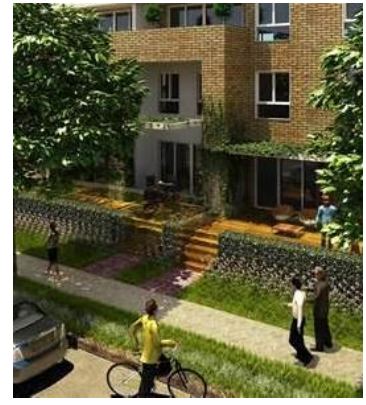

Figura 1.5 - Animação gráfica de urbanismo sustentável.

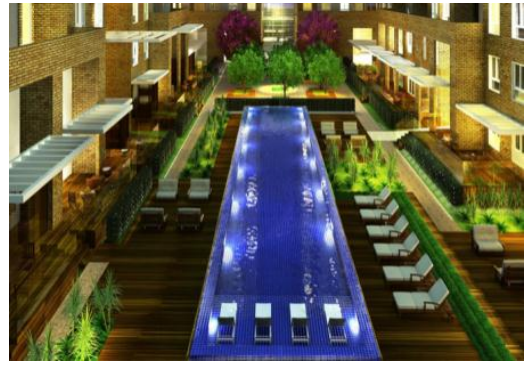

Figura 1.6 - Animação gráfica de urbanismo sustentável.

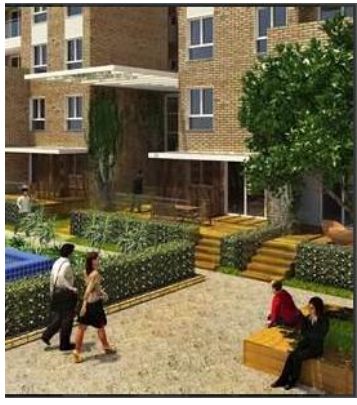

Figura 1.7 - Animação gráfica de urbanismo sustentável.

Disponível em: <http://meioambiente.culturamix.com/recursos-naturais/urbanismo-sustentavel-dicase-significado>. Acesso em 18 set. 2014.

No que concerne à edificação, são essenciais: a adequação do projeto ao clima do local, minimizando o consumo de energia e priorizando as condições de ventilação, iluminação e aquecimentos naturais, utilizando coletores solar térmicos para aquecimento de água, aproveitando a energia eólica para bombeamento de água e o uso de energia fotovoltaica, com possibilidade de se injetar o excedente na rede pública. Um bom exemplo dessa técnica é a economia feita pelo projeto Tamar- Praia do Forte- BA, onde a energia gerada através de placas coletoras é utilizada em todo o complexo e os excessos disponíveis para a rede pública da cidade. Sobre águas e esgotos, é interessante prover a coleta e utilização de águas pluviais, utilizando de dispositivos economizadores de água, reuso de águas, tratamento adequado de esgoto no local e, quando possível, o uso do banheiro seco. Dar atenção para a orientação solar adequada, evitando a repetição do mesmo projeto em orientações distintas; utilizar cobertura verde como opção de envoltória.

O Código de Edificações do DF e a NBR 9050 já exigem como obrigatoriedade nos projetos comerciais e outras edificações como escolas, hotéis e escritórios, a previsão de requisitos de acessibilidade para pessoas com mobilidade reduzida. Essas exigências já fazem parte de um mecanismo de avanços dos projetos sustentáveis.

Um dos grandes desafios na construção civil para preservação dos impactos ambientais é a escolha dos materiais de construção. Nesta etapa, é importante observar e determinar a utilização de materiais disponíveis no local, pouco processados, renováveis, não tóxicos, potencialmente recicláveis, culturalmente aceitos, propícios para a autoconstrução e para a construção em regime de mutirões, com conteúdo reciclado. Além disso, deve-se evitar sempre 
o uso de materiais químicos à saúde humana ou ao meio ambiente, como amianto, clorofluorcarbonos (CFC), hidroclorofluorcarbonos (HCFC), formaldeído, policloreto de vinila (PVC), tratamento de madeira com arseniato de cobre cromatado (CCA) ou celcure, entre outros. Com uma boa especificação dos materiais de construção, o sucesso de uma edificação sustentável é garantido. Esta escolha de materiais de baixo impacto ambiental irá trazer, a longo prazo, a minimização das agressões ao meio ambiente. As Figuras 1.8, 1.9 e 1.10 apresentam um exemplo de edificações sustentáveis.

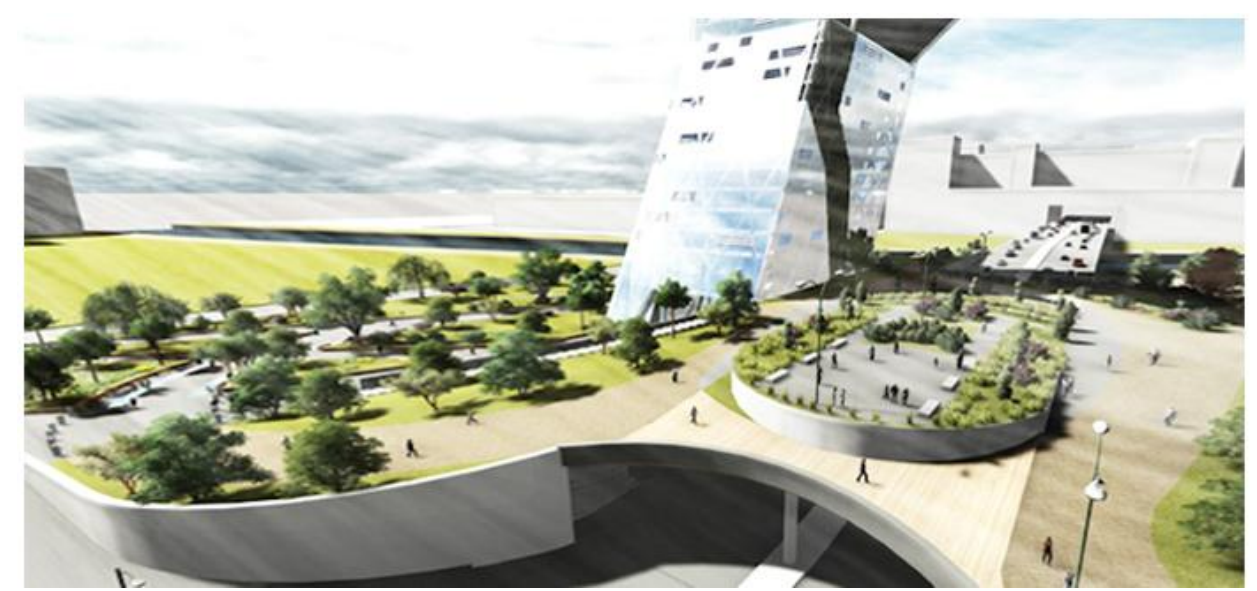

Figura 1.8 - Animação gráfica de edificação sustentável.

Disponível em: <http://www.divex.com.br/imobi/index.php/2011/06/07/arquitetura-sustentavel/> . Acesso em 18 set. 2014.

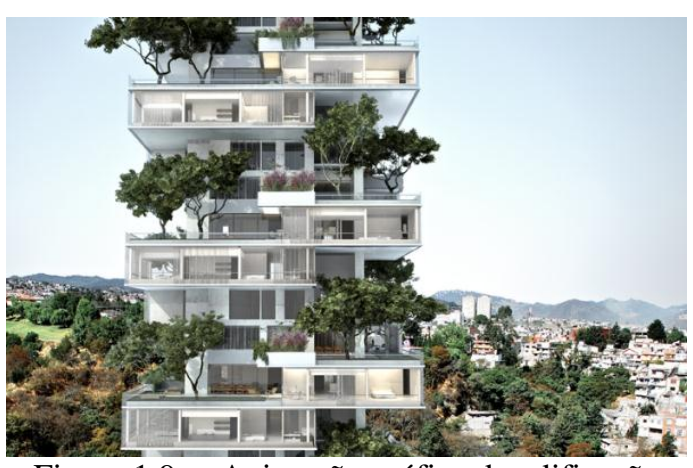

Figura 1.9 - Animação gráfica de edificação sustentável.

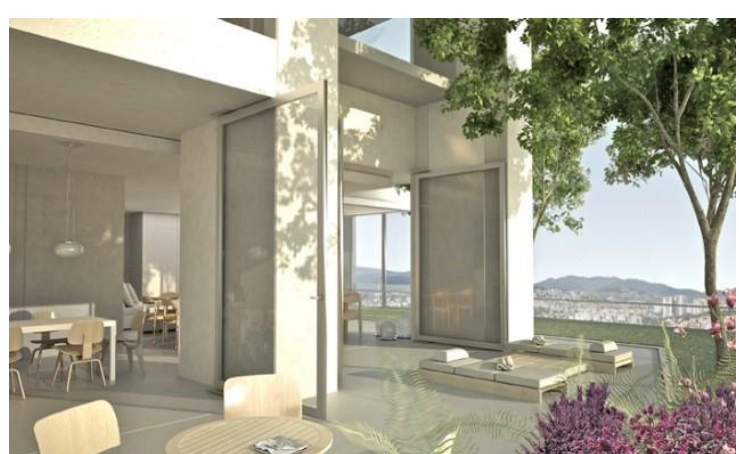

Figura 1.10 - Animação gráfica de edificação sustentável.

Disponível em: <http://www.divex.com.br/imobi/index.php/2011/06/07/arquitetura-sustentavel/>. Acesso em 18 set. 2014.

Conforme a Lei nº 12.305 de 02/08/10 - Política Nacional de Resíduos Sólidos (PNRS), o Ciclo de Vida dos Produtos (ACVP) é uma série de etapas que envolvem o desenvolvimento, o consumo e a disposição final (LANNOY, 2013).

Para Blumenschein (2004), o Ciclo de Vida dos Produtos (ACVP) permite o desmembramento do processo de produção em estágios (Figura 1.11) e, entendendo que a qualidade ambiental é resultado do processo global e complexo, seus impactos são avaliados 
um a um. Entretanto, a mudança de mentalidade e de hábitos de fabricantes e consumidores permitirá uma maior aproximação de um ideal, em um mundo industrializado que pretenda manter seu padrão de vida. Esta é uma ferramenta de grande utilidade na especificação de materiais visando analisar os impactos ambientais que a indústria da construção civil traz ao meio ambiente, priorizando o pensamento sustentável.

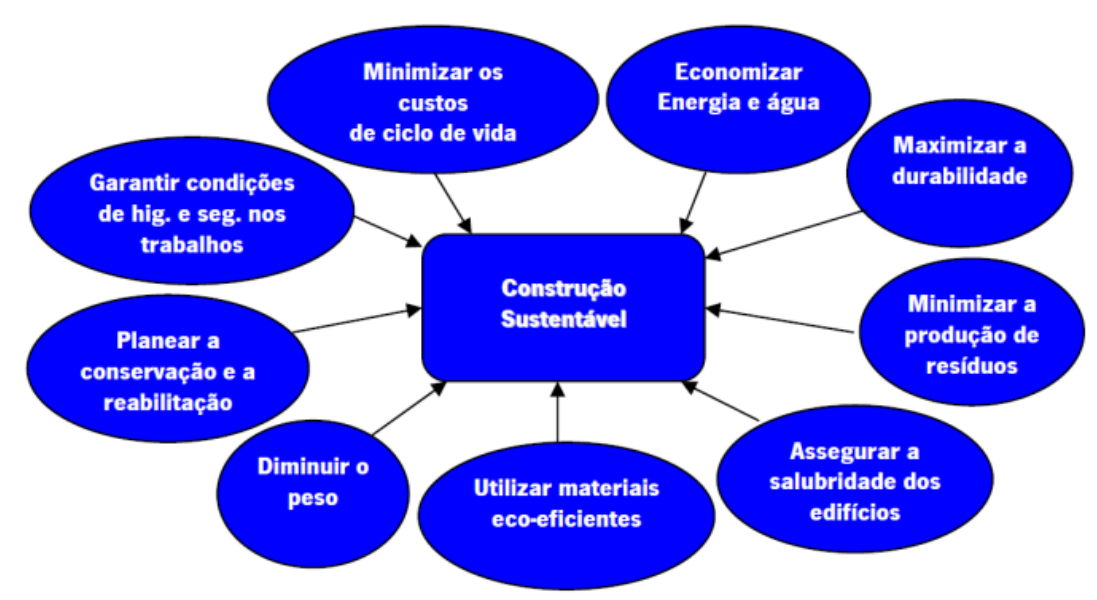

Figura 1.11 - Quadro de prioridades a serem consideradas no desenvolvimento de um projeto.

Fonte: MATEUS, 2009.

\subsection{Materiais sustentáveis de construção}

Um dos primeiros tópicos a se pensar na elaboração de um projeto arquitetônico ecologicamente correto é o uso de materiais de construção alternativos, que possam minimizar os impactos ao meio ambiente.

Dentre esses materiais alternativos, podemos citar o Bambu. O Bambu é uma matéria prima altamente sustentável, pois é abundante e renovável. Como tem sua velocidade de crescimento acelerada, pode ser colhido anualmente sem prejuízos à natureza. Ainda tem um elevado potencial de armazenar carbono. Essa característica de retenção de carbono é um fator que pode interessar empresas de variados setores a entrar nesse ramo de atividade. Por ser uma planta flexível e durável, a variedade de uso do bambu é enorme. Para áreas externas, por exemplo, pode ser usado como: sombreamento, quebra-vento, proteção contra a erosão e drenagem. Também tem sua utilidade em estruturas como vigas, pilares e telhado, tendo um tratamento específico que o esterilize contra pragas, estenda a durabilidade e de fácil manutenção. Já em áreas internas, seu uso pode ser na área de decoração, sendo utilizado como revestimento de paredes ou pisos, pois requer pouca manutenção, é durável e resistente, além 
de belo ou até mesmo artesanatos. A sua utilização na construção civil não surgiu com essa ênfase à sustentabilidade atual. Em países asiáticos e americanos, como China, Japão, Índia, Equador e Colômbia, a técnica já é bem desenvolvida e utilizada inclusive para edifícios de pequeno porte e pontes. No caso do Brasil (Figura 1.12), a situação é um pouco distinta. Essa cultura precisa ser difundida primeiramente para após ter a criação de um material didático para difundir as técnicas de utilização e treinamento da mão-de-obra. (Disponível em www.ecodesenvolvimento.org). Mas essa realidade está mudando após a aprovação da Lei Federal no 12.484 de 08 de setembro de 2011, que trata da Política Nacional de Incentivo ao Manejo Sustentado e ao Cultivo do Bambu (PNMCB). Esta Lei tem como objetivo o desenvolvimento da cultura do bambu no Brasil por meio de ações governamentais e de empreendimentos privados.

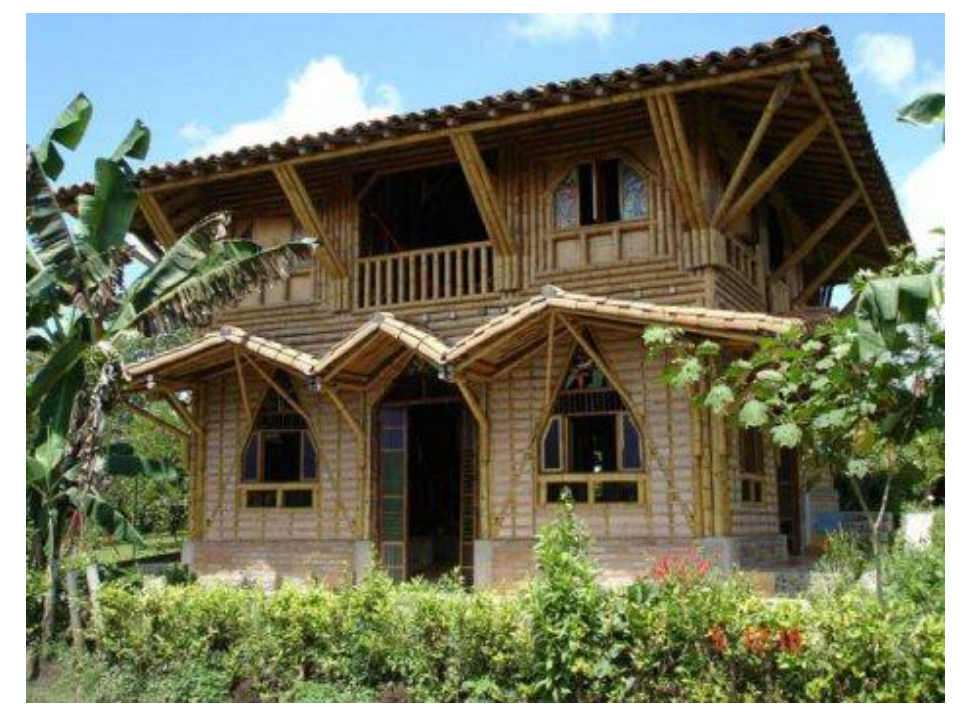

Figura 1.12 - Projeto residencial do arquiteto colombiano Simon Velez, localizada no sul da Bahia.

Disponível em: <http://arquiteturaesustentabilidade.wordpress.com/2012/11/14/o-bambu-comoalternativa-na-construcao/>. Acesso em 22 set. 2014.

Outro material alternativo é a tinta ecológica, que utiliza de pigmentos naturais (Figura 1.13), como minerais e vegetais. A tinta com pigmentos minerais é feita à base de terra crua e emulsão aquosa. Sua matéria prima é retirada de jazidas certificadas. Essa tinta não agride o meio ambiente, pois não possui nenhum tipo de Composto Orgânico Volátil (COVs considerado um poluente perigoso), nem biocidas, estabilizantes ou corantes. A tinta com pigmentos vegetais é à base de insumos animais (como a caseína, que é um ligante extraído do leite da vaca), ainda sendo vendidas em embalagens reutilizáveis ou recicláveis. A Tinta Natural é durável, lavável e não descasca com a umidade. São as melhores quanto à saúde do morador e das habitações, pois permitem que ocorra a difusão do vapor d'água (que a parede respire) e, como são alcalinas, não permitem que fungos e microrganismos se instalem na casa. Para ser 
classificada como ecológica, a tinta deve ter seu ciclo de vida avaliado, incluindo dispêndio energético, uso, consumo de água, efluentes gerados, embalagens, descarte e reciclagem de materiais e insumos. A quantidade de solventes e produtos de limpeza que se gastam dentro da fábrica para limpar os próprios recipientes em que se produzem as tintas é considerada para se certificar uma tinta como ecológica. E, em tese, hoje se sabe que só existe um solvente de tipo ecológico: a água.

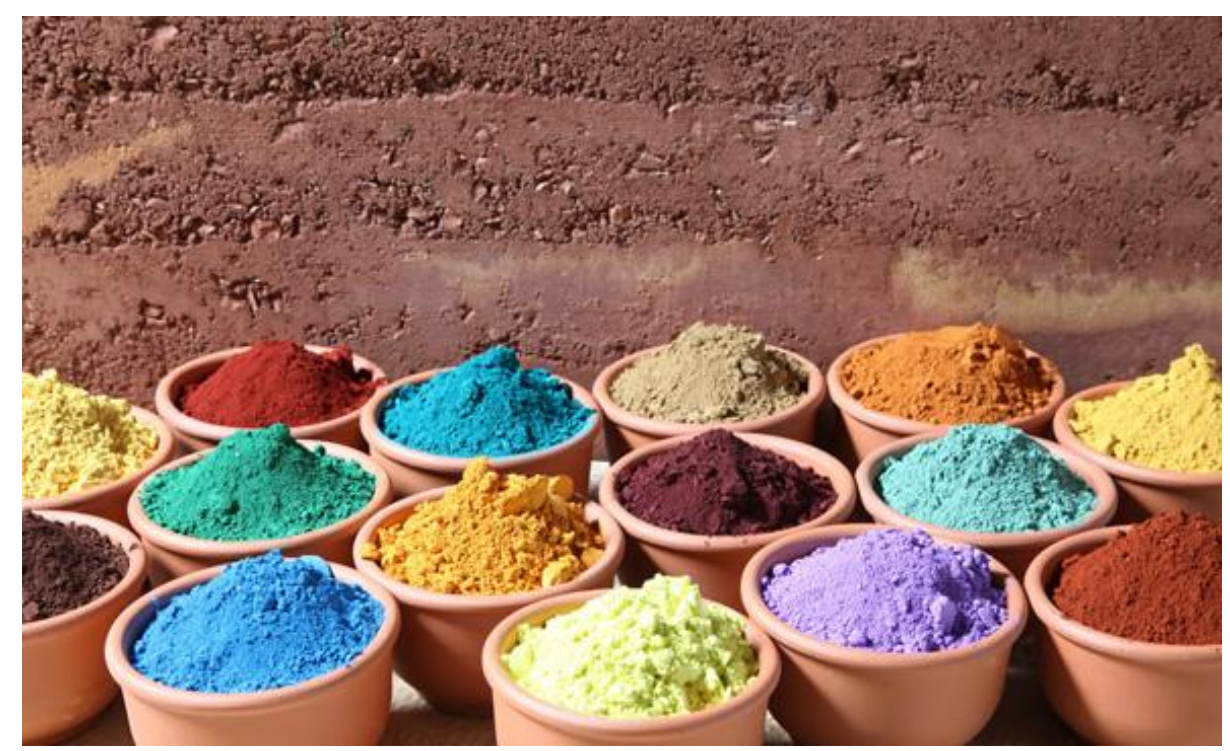

Figura 1.13 - Pigmentos naturais usados nas tintas ecológicas.

Disponível em: <http://www.embarro.com/embarro-introducao.html>. Acesso em 22 set. 2014.

Outra ideia de materiais ecológicos é o uso da madeira plástica, que, conforme observado nas Figuras 1.14 e 1.15, têm diferentes especificações e usos. Segundo o Wikipédia:

Madeira plástica (do inglês Wood-plastic composites (WPC)) é um tipo de material composto de fibra de madeira/serragem de madeira e de termoplástico(s) (inclui $\underline{\mathbf{P E}}, \underline{\mathbf{P P}}, \underline{\mathbf{P V C}}$ etc). Matéria-prima 100\% reciclada. Polímeros mais fibras naturais conferem alta resistência e durabilidade aos perfis pultrudados. O material utiliza de 30 a $40 \%$ de polímeros (PE e PP de alta densidade) e 60 a 70\% de fibras orgânicas descartadas pelas indústrias do agronegócio, alimentícia e outras. Material não racha, é impermeável e não gera subprodutos ou resíduos na fabricação. Pode ser trabalhado de maneira similar à madeira tradicional.

É uma opção sustentável para ter seu uso em ambientes externos como decks, piers e outros. Esse material é altamente resistente à corrosão de intempéries e é imune à pragas, cupins, insetos e roedores. Apesar da aparência lembrar muito a madeira comum, sua fabricação é feita com diversos tipos de plásticos reciclados e resíduos vegetais de agroindústrias. Além de decks, piers, assoalhos em geral e revestimentos de fachadas e paredes, esse material pode 
ser amplamente utilizado em objetos de uso diário e decoração, como mesas, bancos, lixeiras, guarda-copos e outros. A Madeira Plástica não empena, não racha e não solta farpas, como a madeira comum. Além disso, não absorve umidade e, portanto, não cria fungos nem mofa. Também não precisa de pintura ou qualquer outra manutenção.

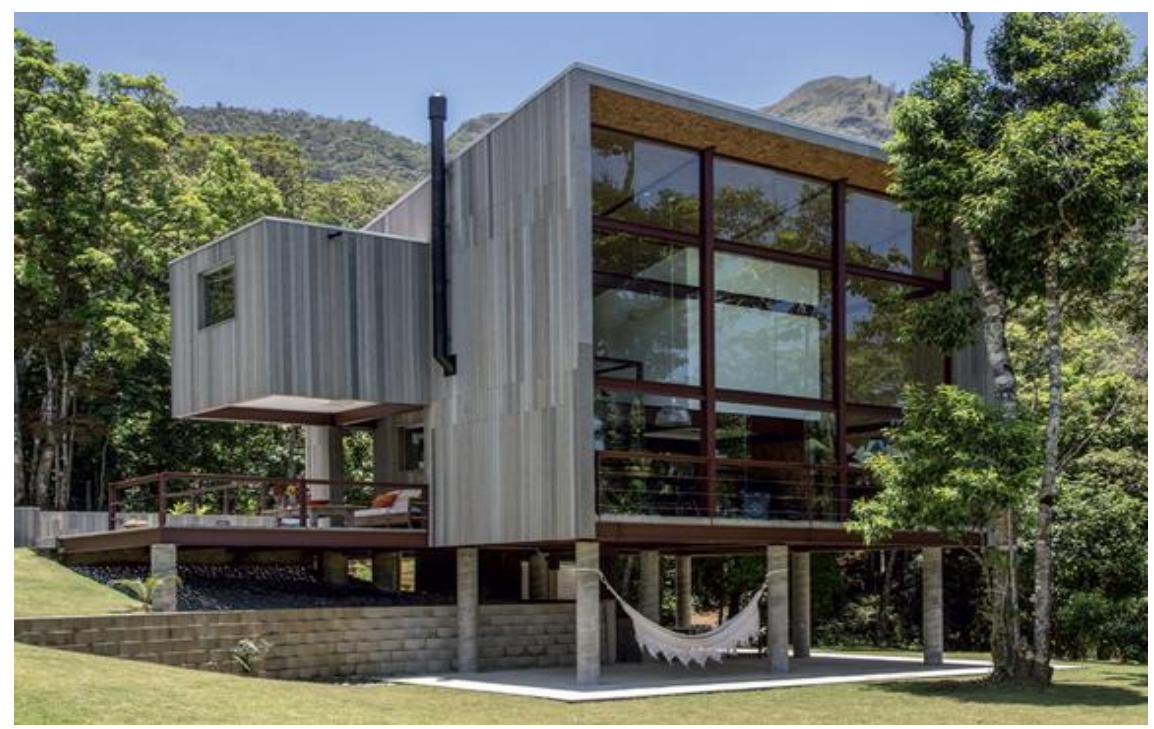

Figura 1.14 - Uso da madeira plástica em fachadas. Projeto de Tatiana Terry e Luciano Alvarez. Residência localizada na Serra Fluminense.

Disponível em: <http://casa.abril.com.br/materia/casa-sustentavel-osb-madeira-plastica\#12〉. Acesso em 22 set. 2014.

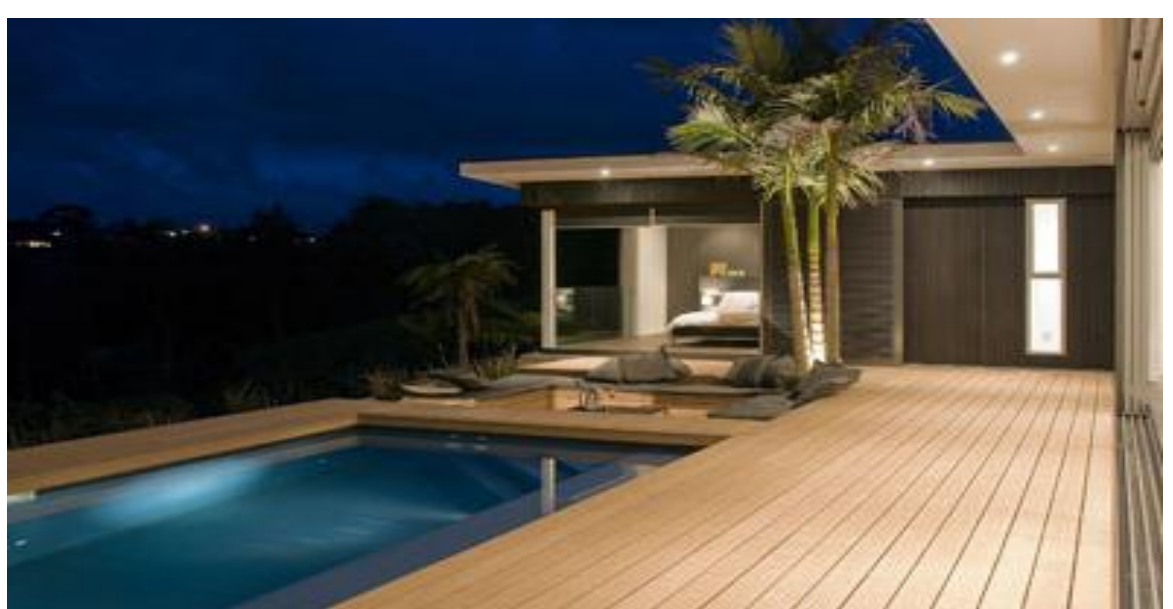

Figura 1.15 - Uso da madeira plástica em fachadas e deck. Imagem ilustrativa feita pela Madeplast.

Disponível em: <http://webjornalismoup.wordpress.com/2011/03/31/empresa-incubada-na-up-fabricamadeira-plastica/>. Acesso em 22 set. 2014 


\section{CAPÍTULO 2}

\section{ESTUDO E LEVANTAMENTO DAS TELHAS}

O processo de especificação de materiais com baixo impacto ambiental possui uma abordagem multifacetada, onde o profissional se depara com uma quantidade grande de informações pouco objetivas e/ou direcionadas. Muitas vezes é obrigado a recorrer a consultores do próprio selo ou certificação para entender os procedimentos obrigatórios de como alcançar a pontuação desejada (LANNOY, 2013).

Segundo a Norma de Desempenho NBR 15.575, não há distinção entre materiais ruins ou bons, mas sim materiais com caraterísticas próprias que devem ser levadas em conta na escolha e no momento da aplicação. Não entram em consideração as deficiências de fabricação e as falhas causadas pelos materiais decorrentes da inadequação do uso e sua especificação. $\mathrm{Na}$ busca constante da sustentabilidade, o ciclo de vida dos produtos ganha espaço cada vez maior no mercado construtivo quanto à durabilidade, a menor exploração de recursos naturais renováveis ou não, o menor consumo de água e de energia e o menor o teor de poluentes gerados nas fábricas e no transporte das matérias-primas e dos produtos.

Para certificar se o material é ecologicamente correto ou se causa menos impacto ao meio ambiente, é necessário verificar se a matéria-prima é virgem ou reciclada, se é um recurso renovável ou não e como essa matéria-prima é extraída da natureza. Deve-se ter a preocupação de como foi feito o processo produtivo do material, se houve baixo consumo de energia e de água e se o processo de fabricação é poluente do ar, água, terra ou som. É ainda importante averiguar que tipo de resíduo é gerado na produção do material e se sua manutenção e instalação também geram resíduos. A partir desta etapa, faz-se necessário examinar a logística da distribuição do produto, inclusive se a embalagem de transporte possui potencial de reciclagem ou reuso. E para finalizar, verificar a certificação (ISO 14001) ou selo de avaliação e qualificação.

Neste capítulo apresentamos um levantamento das telhas analisadas e avaliadas dentro da qualificação dos selos.

\subsection{Telhas Fotovoltaicas}

A transferência e conversão de energia estão envolvidas nos três modos de transmissão de calor: condução, convecção e radiação (Figura 2.1). Nestes processos, os fluxos sempre 
ocorrem devido à diferença de temperatura (do maior para o menor valor), o que define o calor sensível. Quando ocorre uma mudança de estado, observa-se o que é denominado calor latente (nos processos de evaporação e condensação). Dentre estes, a condução e radiação devem ser classificadas como processos de transmissão de calor, pois estes dois mecanismos dependem para sua operação da mera existência de uma diferença de temperatura.

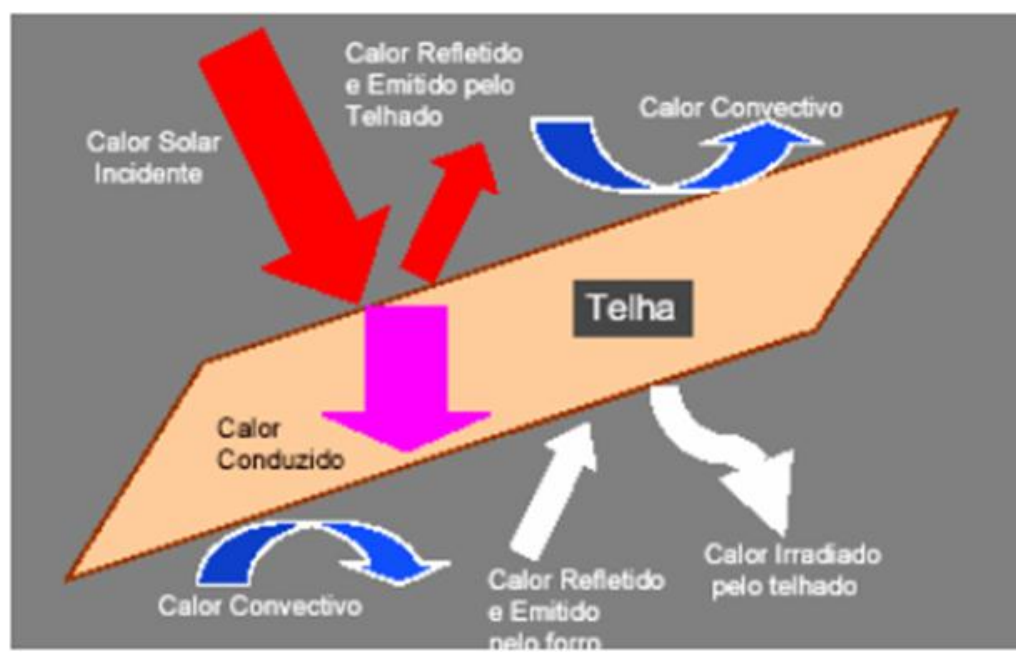

Figura 2.1 - Representação das trocas de calor de um telhado.

Fonte: PERALTA, 2006

Os processos de transmissão de calor, na prática nunca ocorrem separados, pois sempre há simultaneidade entre dois ou três destes fenômenos. A intensidade de qualquer processo de transferência de calor pode ser mensurada tanto como fluxo de calor, quanto como densidade do fluxo de calor (PERALTA, 2006).

Para aproveitar a incidência do calor das telhas e transformá-las em produtoras de energia, a utilização das telhas fotovoltaicas hoje, é uma boa opção na troca dos painéis solares. As telhas fotovoltaicas têm o mesmo aspecto que as telhas cerâmicas tradicionais, com a diferença de integrarem mini-painéis solares na parte lisa. Desta forma, os telhados podem produzir energia. Esse tipo de telha está ganhando cada vez mais espaço no mercado construtivo, especialmente em países como a Itália, onde os centros históricos das cidades têm muitas regras de preservação, o que impede a construção de grandes painéis fotovoltaicos. (24harquitetura.blogspot.com.br). As telhas fotovoltaicas podem contornar o problema estético das placas e são feitas de argilas naturais sem aditivos. Mesmo em telhados pré-existentes, consegue-se fazer a substituição das telhas comuns pelas fotovoltaicas, desde que sejam do mesmo modelo, bastando interligar as conexões em série, paralelo ou série-paralelo por debaixo delas, com os condutores (fios) presos por presilhas plásticas nas ripas de madeira que as 
sustentam. Em caso de dano, basta substituir a telha danificada, o que é uma operação fácil e de baixo custo, pela própria natureza modular do telhado tradicional. A cobertura é de uma área aproximada de $40 \mathrm{~m}^{2}$ gera cerca de $3 \mathrm{kw}$ de energia. (www.econodesenvolvimento.org).

Um telhado que atenda a função adicional de fornecimento de energia renovável é uma opção a se observar, pois tem uma considerável economia de energia e gás. O investimento pode ser alto a princípio (o que faz muita gente desistir do investimento inicial), mas após alguns meses, este custo se reduz a zero. Existe no mercado uma grande variedade de telhas solares que têm materiais que as tornam mais flexível e podem assumir qualquer forma. Um telhado completo ou parcialmente coberto com telhas solares pode satisfazer as necessidades de energia de uma residência.
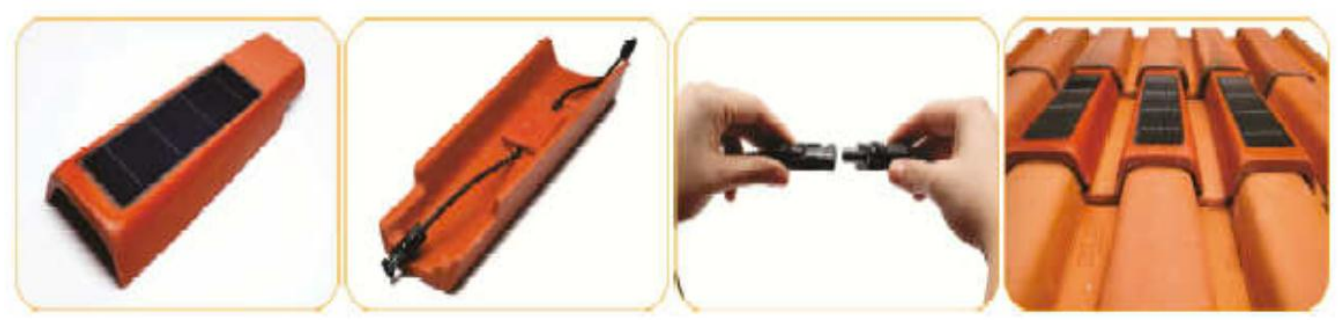

Figura 2.2 - Telha solar fabricada pela empresa Solbravo - Curitiba.

Fonte: BODÃO, 2014.

A telha solar desenvolvida pela empresa brasileira Solbravo Desenvolvimento de Tecnologias Sustentáveis S/A é fabricada a partir de um composto polimérico, por um processo denominado casting. A composição da telha foi determinada a partir da variação do porímero base e de aditivos, como cargas, estabilizantes, protetores de radiação UVA, entre outros, obtendo-se assim um material com boas propriedades mecânicas e com resistência química ao intemperismo. O processo revelou-se economicamente viável e também permitiu a confecção de telhas solares nas mais variadas formas. A Figura 2.2 apresenta imagem de telhas modelo "plan", na variação "capa", à base de resina polimérica com módulos solares de silício monocristalino encapsulados. A combinação de várias dessas telhas ligadas em série permite que toda a área do telhado seja utilizada para a conversão da energia solar em elétrica. (Bodão, 2014). Na Figura 2.3, observa-se que as telhas repetem o mesmo padrão de ter a placa solar na base das telhas, podendo cobrir a metragem do telhado de acordo com as necessidades do proprietário. 


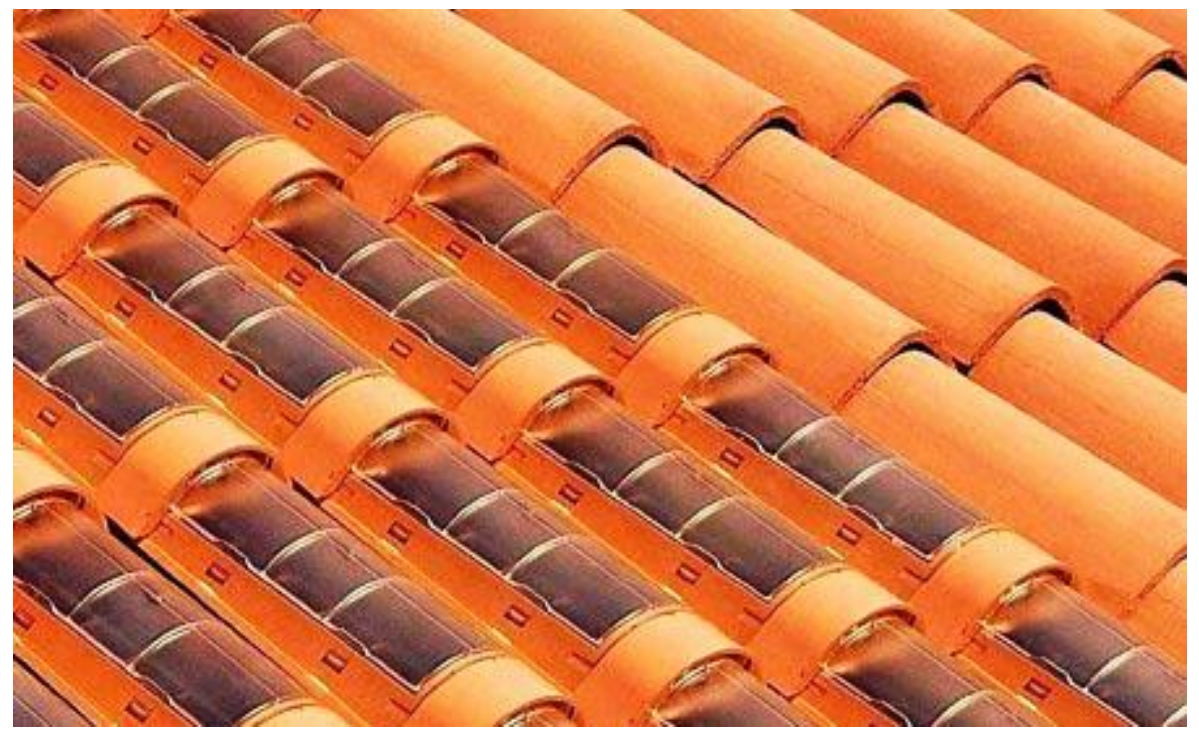

Figura 2.3 - Telha solar fabricada pela Tegola Solare

Fonte: 〈www.ecodesenvolvimento.org>. Disponível em 25 out. 2015

\subsection{Telhas de tetra pak}

Considerando as telhas recicladas como uma forma de garantir sua segura inserção no mercado, é preciso conhecer suas características, para verificar seu desempenho em relação aos materiais convencionais, a fim de serem estabelecidos critérios e classificações adequadas.

A caixinha de leite Tetra Pak (Figura 2.4) é composta por três materiais: papel, polietileno e alumínio, nas proporções, em peso, de 75\%,20\% e 5\%, respectivamente, que se torna também em resíduo, podendo ser usada para fabricar telha cartonada. As embalagens cartonadas são constituídas por multicamadas de papel, plástico e alumínio e variam em tamanho, forma e maneira de abertura, as quais são escolhidas de acordo com o produto a ser envasado. Em sua constituição, o papel representa $75 \%$ em massa da embalagem, enquanto o alumínio e o plástico representam 5\% e 20\%. Esses materiais, dispostos em ordem determinada, passam por um processo de laminação, que consiste, simplificadamente, em realizar uma compressão sobre as folhas dos diversos constituintes. (JALES, 2013) 


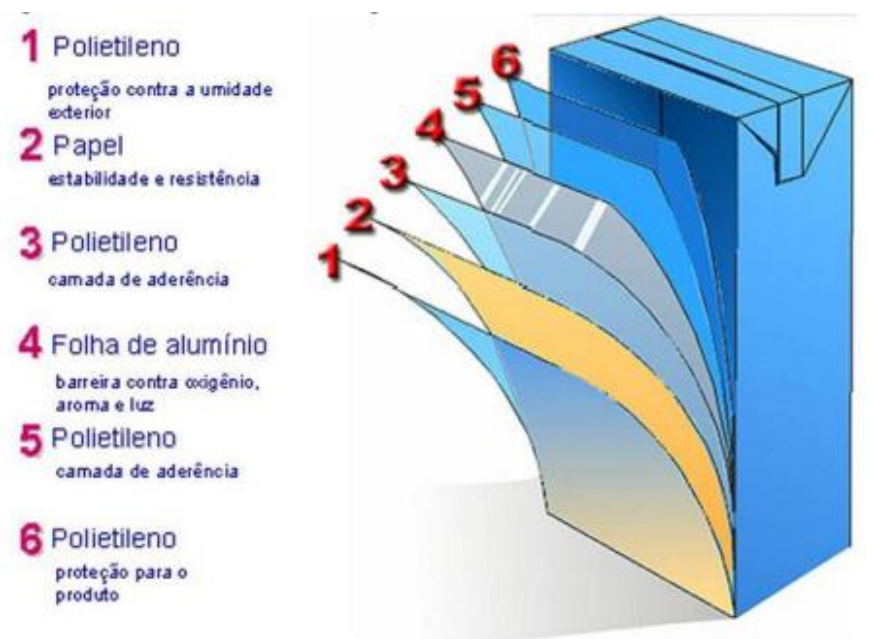

Figura 2.4 - Camada das embalagens Tetra Pak.

Fonte: JALES, 2013.

As telhas Tetra Pak (Figuras 2.5 e 2.6) têm como matéria-prima o polietileno e o alumínio, retirados destas embalagens a partir da reciclagem pós-consumo e são fabricadas por um processo que usa pressão e calor. A ideia de reciclagem das embalagens surgiu em 1999, que até então estava resumida a reutilização do papel, que era retirada pela indústria papeleira para a confecção de papelão ondulado e caixas. Tendo como base que a mistura de plástico e alumínio das embalagens é um material caro e resistente e, o Departamento de Meio Ambiente da Tetra Pak iniciou um estudo sobre as maneiras de prensar e transformar a mistura em placas rígidas, que poderiam ser aproveitadas na construção civil como tapumes, revestimentos, dentre outros. Logo surgiu a utilização do produto final polietileno-alumínio para produção de telhas, já que este não perde a sua capacidade de reciclagem. (Disponível em www.portal.rebia.org.br).
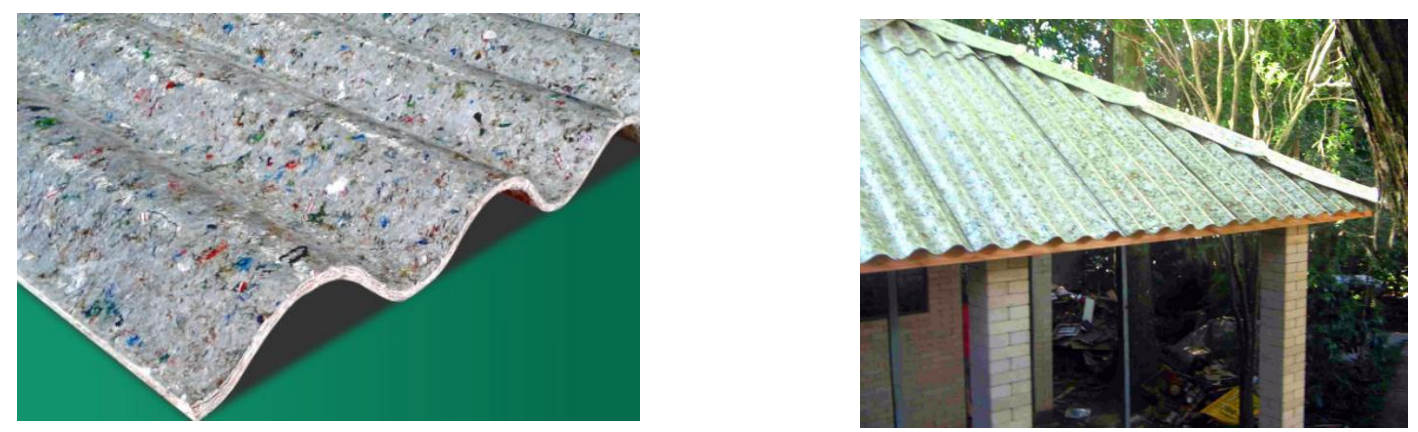

Figura 2.5 - Telha ecológica Tetra Pak

Fonte: <http://www.ecopex.com.br/telhas-e-placas/telha-ecologica-tetra-pak/>. Disponível em 02 out. 14.

Figura 2.6 - Telhado de Casa com Telha Tetra Pak.

Fonte: <http://fotos.habitissimo.com.br/foto/telhado-feito-com-telhas-de-embalagens-tetrapark_241 44>. Disponível em 25 out. 15.

Por serem inquebráveis, estes produtos podem ser quase que cem por cento reaproveitados após retirados das reformas, pois mantêm suas condições originais de uso além 
de não quebrarem no transporte pela sua alta resistência. Por não serem produtos biodegradáveis, agrega-se valor ecológico ao produto final o fato de a matéria-prima ser fruto de reciclagem ao invés de originar-se de fontes virgens. Desta forma, evita-se que toneladas de material plástico e alumínio sigam para aterros sanitários. Trata-se também de ser um produto ecológico por não ter em seu processo de transformação, nenhum tipo de efluente ou poluente atmosférico. Não é cancerígeno. Também não agride de outras formas a saúde de quem o produz, manuseia ou usa, pois é um material limpo e inodoro. Em um modo comparativo, as telhas com uso similar como as de amianto e fibrocimento chegam a alcançar a temperatura média de $65^{\circ}$ Celsius. As telhas Polietileno-Alumínio são $40 \%$ menos quentes, chegando a alcançar a temperatura média de $39^{\circ}$ Celsius, diminuindo a dispersão do calor para dentro do ambiente. Além disso, são mais baratas (cerca de 25\%), resistentes, e duradouras.

Já em um estudo apresentado no $26^{\circ}$ Congresso Brasileiro de Engenharia Sanitária e Ambiental - Santa Catarina, foi realizada uma comparação entre a telha fabricada a partir de embalagens Tetra Pak e a telha de fibrocimento. Nota-se um aumento de temperatura da telha de fibrocimento em relação á telha de tetra pak.

Observou-se que o aumento de temperatura interna na célula teste coberta com a primeira telha foi de $5,50^{\circ} \mathrm{C}\left(\operatorname{de} 21,90^{\circ} \mathrm{C}\right.$ para $\left.27,40^{\circ} \mathrm{C}\right)$ e na célula teste coberta com a segunda telha o aumento foi de $6,30^{\circ} \mathrm{C}$. Isso demonstra uma diferença no aumento de temperatura de $0,80^{\circ} \mathrm{C}$. A Figura 2.7 ilustra a diferença de temperatura entre as duas células teste. Isso mostra que apesar da telha de embalagens Tetra Pak ter apresentado apenas $66,67 \%$ da espessura da telha de fibrocimento, essa obteve melhor desempenho no isolamento térmico. (http://www.cabo.pe.gov.br/)

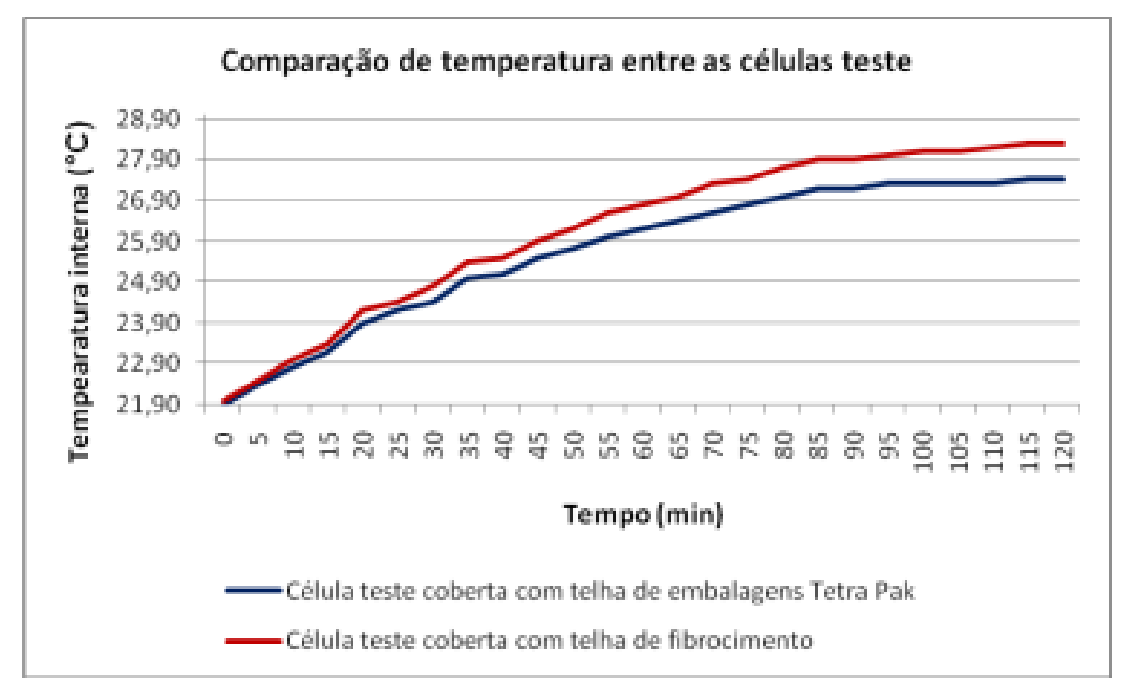

Figura 2.7 - Telha Tetra Pak/Telha de Fibrocimento- temperatura (conforto térmico)

Fonte: <http://www.cabo.pe.gov.br/pners/CONTE\%C3\%9ADO\%20DIGITAL/RECICLAGEM/PRODU \%C3\%87\%C3\%83O\%20TELHAS\%20-\%20TETRA\%20PAK\%20E\%20TUBOS\%20DE\%20PAS

TA.pdf>. Disponível em 25 out. 2015. 
As telhas Tetra Pak têm algumas outras qualidades como a leveza, proporcionando economia na estrutura do telhado; são resistentes ao fogo e não propagam chamas; têm alta resistência à flexão; não propagam som; não danificam com chuvas de granizo; são resistentes a produtos químicos; têm fácil fixação de pregos, parafusos e rebites; podem receber pintura acrílica e ainda podem ser cortadas em todas as direções, o que reduz a produção de resíduos na obra.

\subsection{Telha onduline de fibra vegetal}

As telhas de fibras vegetais estão ganhando espaço no mercado por ser um produto de fácil aplicação, ecologicamente correto e de grande durabilidade. Podem ser feitas de fibras de não-madeiras como sisal, bananeira e coco e com fibras de madeiras como pinho e eucalipto. Também existem as produzidas com fibras vegetais de papel reciclado, como é o caso das telhas Onduline.

A Onduline é multinacional francesa fabricante de telhas de fibra vegetal, possui uma demanda de dois milhões de telhas ecológicas por ano. Por serem sustentáveis, a cada nove telhas fabricadas, uma árvore é poupada no processo. Há todo um trabalho na coleta de papel reciclado, coloração e impermeabilização até chegar à embalagem final. Para começar a fabricação das telhas, a empresa compra papel e papelão de cooperativas. Depois, dissolvem o material em água quente para extrair a fibra celulose. Após este processo, uma centrífuga tira as impurezas da massa para deixá-la lisa. Clips e grampos são descartados. A massa é esticada e exposta em uma esteira aquecida para eliminar qualquer vestígio de água na telha. Ao sair, uma camada de resina e pigmentação orgânica é aplicada ao material que, em seguida, passa por uma forma onde ganha as ondulações, regulares ou não. Após a secagem, a telha é cortada e impermeabilizada. Assim que o corte é feito, as telhas são mergulhadas em betume, que oferece impermeabilização, resistência e proteção UV, para manter a cor e evitar a descamação do produto. Através desse processo, passam a absorver apenas 0,0003\% de água, mesmo sendo reciclada e com o peso muito leve: $3,9 \mathrm{~kg} / \mathrm{m}^{2}$. Após estarem secos, os produtos estão prontos para o consumidor. Essas telhas ecológicas duram em média 30 anos. A empresa atua na indústria de construção civil com produtos sustentáveis dentro do seu processo de produção, utilizando recursos que são reciclados e reaproveitados. Na fábrica, por exemplo, o consumo total de energia é de 2,8 Kwh por $\mathrm{m}^{2}$ de telha (energia elétrica e gás natural). A água é reaproveitada, pois o circuito é fechado, havendo apenas a reposição do que é evaporado. 
Conforme fabricante, algumas características das telhas de fibra vegetal são: leveza, resistência, baixa absorção térmica e acústica, fácil manuseio e instalação, impermeabilidade, flexibilidade e ainda é anticorrosiva. O custo dessas telhas é em torno de $10 \%$ mais caro que as de cerâmicas convencionais. Mas considerando o conjunto (estrutura e tempo de mão-de-obra), seu valor é inferior. Um bom comparativo entre as telhas ecológicas da Onduline com as telhas cerâmicas é que as telhas de barro consomem 58,90\% a mais de materiais do que o telhado feito com o material ecológico. Já em relação às telhas de fibrocimento, o telhado consome em torno de $27,8 \%$ a mais de madeira e $1,3 \%$ a mais de materiais do que o telhado de telha ecológica.

As telhas Onduline ainda possuem o Selo ISO 9001 (norma de padronização e padrão de qualidade) e o Selo Verde (garantia de que o produto não agride as florestas tropicais).

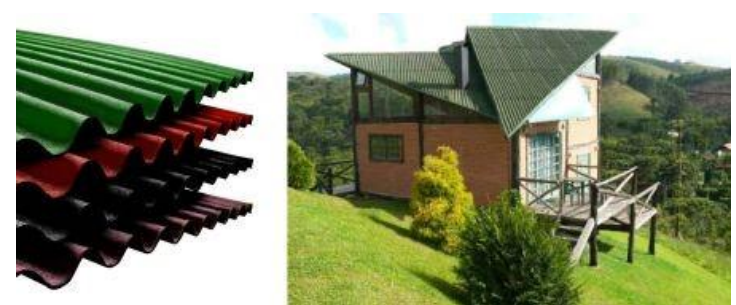

Figura 2.8 - Telha ecológica Onduline.

Fonte: 〈http://www.cliquearquitetura.com.br/portal/dicas/view/telhas-ecologicas/193>. Disponível em 06 out. 14.

\section{4 -Telha cerâmica vasatex e telha ecologic lux - pet}

Existem várias empresas que fabricam telhas cerâmicas no Brasil. Há alguns anos, esse tipo de telha dominava o mercado da construção civil no aspecto de cobertura. Hoje, a tecnologia avançou e novas telhas surgiram - melhorando a qualidade e diversificando o mercado.

A telha cerâmica Vasatex é fabricada pela empresa Intercil. Conforme fabricante, os produtos são ecologicamente corretos e estão no mercado há mais de 30 anos. Possuem diversos modelos de telhas e todos eles passam por rigorosos controles normatizados pela ABNT e auditados periodicamente pelo INMETRO através do CCB - Centro Cerâmico Brasileiro. A Vasatex recebeu em 2003, o selo de certificação INMETRO/CCB OCP-10, passando a fazer parte de um grupo em certificação de cerâmica no Brasil. Ainda conforme o fabricante, a cerâmica produzida dispõe de tecnologia de ponta em todos os processos, que compreendem a exploração de matéria prima, prensagem, secagem e queima. A sustentação de todo esse processo se dá devido a constantes investimentos em qualificação de mão de obra, pesquisas e 
análises das tecnologias disponíveis. Há mais de uma década, a Vasatex já tem instalado um completo laboratório para análises e ensaios de seus produtos, muito antes do INMETRO ter definido padrões, através da ABNT, para telhas fabricadas a partir da cerâmica vermelha. Dentre as telhas Vasatex, as telhas duplas com linhas retas ou curvas são telhas ecológicas produzidas com combustíveis energéticos reciclados. Possuem matéria-prima natural extraída de argileiras normatizadas e são feitas em sistema PPA (um processo automatizado de produção que garante melhor acabamento e resistência). Há também as telhas translúcidas (Ecologic Lux) que foram desenvolvidas em plástico tipo PET para dar claridade, proporcionando luz natural e contribuindo para a economia de energia.

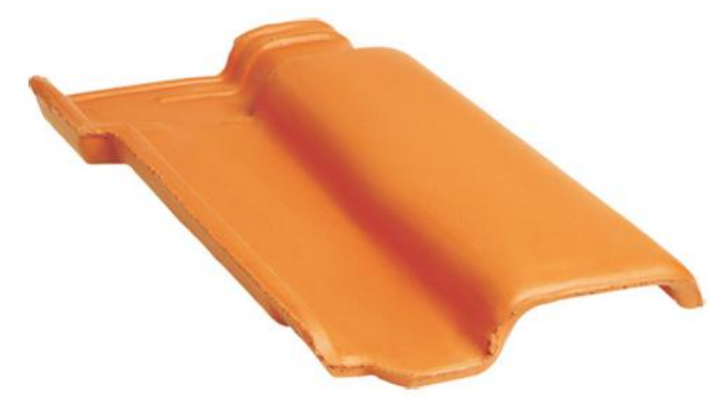

Figura 2.9 - Telha cerâmica Versatex.

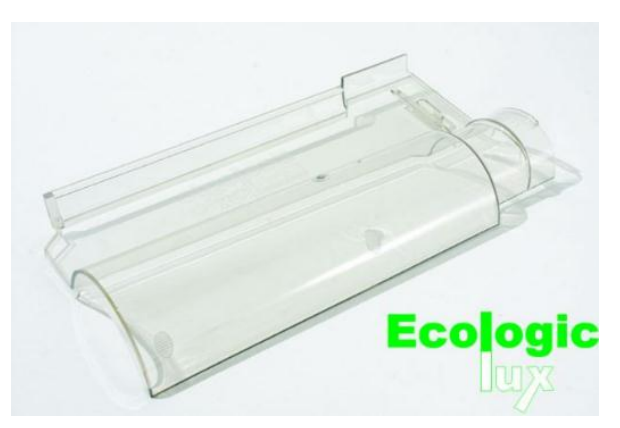

Figura 2.10 - Telha Ecologic Lux.

As telhas de PET são produzidas através de uma mistura de resinas poliméricas e carbonato de cálcio. Na sua fabricação, as garrafas são separadas de acordo com as cores e depois passam por uma máquina especial, onde há a separação do rótulo e do plástico. Ambos os materiais são reutilizados. Já limpas e secas, as garrafas PET são trituradas até amolecerem e ficarem pastosas. Após esse processo, são formadas as telhas.

Um aspecto interessante como comparativo entre as telhas cerâmicas e as telhas PET, é que as telhas de garrafas PET possuem a mesma resistência que as telhas cerâmicas, porém são bem mais leves. Isso influencia no peso da estrutura do telhado e traz economia à obra, apesar de terem um custo maior que as cerâmicas no início. As telhas PET também têm grande durabilidade por serem fabricadas com plástico e resistem por muitos anos, diminuindo a extração e o uso de recursos naturais por mais tempo.

Ainda em relação à fabricante Vasatex, conta-se ainda com a linha Hidro, que consiste em um tratamento opcional para toda a linha de telhas Vasatex, onde elas são hidrofugadas por um processo automatizado na própria fábrica. Este tipo de tratamento é feito na camada interna da telha, diminuindo a absorção de água, resultando em maior durabilidade. 


\subsection{Telha de fibrocimento eternit}

As telhas de fibrocimento são compósitos cimentícios reforçados com fibras para agregar propriedades de resistência, tenacidade, ductibilidade e durabilidade ao composto. Sem o reforço das fibras, os materiais cimentícios apresentam baixa resposta à tensão, com pouca resistência a tração e ductibilidade.

As fibras usadas como reforço podem ser naturais ou artificiais e, ambas, podem ainda ser classificadas em orgânicas ou inorgânicas. Normalmente, as fibras naturais são obtidas de vegetais e sem a utilização de processos industriais. Assim, temos como exemplo de fibra natural orgânica a celulose, e de fibra natural inorgânica o amianto e a sepiolita. Como exemplo de fibra artificial orgânica temos o poliéster e o alumínio e ainda a fibra de vidro como fibra artificial inorgânica.

O processo mais usado na fabricação das telhas de fibrocimento é o de Hatschek. Nele, cimento, alguns minerais, fibras e água são colocados em um tanque misturador, gerando uma suspensão. Em seguida, colocados em uma cuba com cilindros envoltos em tela que retém parte da mistura e descarta o excesso de água para o interior do cilindro. O material retido nos cilindros forma finas camadas que são agrupadas em um feltro, que, em seguida, passa por caixas de vácuo para retirar a água ainda presente. Finalmente, as camadas são acumuladas e, a seguir, prensadas e moldadas em um cilindro, gerando os mais diversos tipos de telhas de fibrocimento.

As telhas de fibrocimento têm ampla utilização devido ao seu baixo custo de aquisição. Além disso, por serem bastante leves, permitem a utilização de madeiramento mais esbelto e, consequentemente, menor sobrecarga na estrutura. Uma estrutura de telhado mais esbelta proporciona menor gasto com a mão de obra de montagem. Por tudo isso, os telhados de fibrocimento apresentam o menor custo total entre as opções mais usadas no Brasil.

Segundo o site ambientes.ambientebrasil.com.br,

Além de ser um material relativamente barato e de fácil extração, a estrutura fibrosa
do amianto confere a ele propriedades físicas e químicas especiais, que o torna
virtualmente indestrutível. Caracteriza-se também por possuir propriedades que se
destacam quando comparadas com outros materiais: alta resistência mecânica
(comparada ao aço); elevada superfície específica, a qual indica o grau da abertura do
material; incombustibilidade; baixa condutividade térmica; resistência a produtos
químicos, particularmente estável em diferentes valores de pH; capacidade de filtrar
micro organismos e outras substâncias nocivas; boa capacidade de filtragem; boa
capacidade de isolação elétrica e acústica; elevada resistência dielétrica; durabilidade,
resistindo ao desgaste e abrasão; flexibilidade; afinidade com cimentos, resinas e 
isolantes plásticos; parede externa de caráter básico e compatível com a água e facilidade para ser tecido ou fiado.

As telhas de fibrocimento podem ser usadas sobre lajes de concreto, o que barateia a construção por não ter que impermeabilizá-la. Uma observação importante no uso das telhas de fibrocimento é em relação ao colchão de ar entre estas e a laje. Se as telhas foram instaladas a uma pequena distância ou coladas na laje, este colchão terá um pequeno volume de ar e sem renovação, o que leva ao aquecimento excessivo tornando o ambiente desconfortável, o que a desqualifica em termos de eficiência energética.

Quanto à sustentabilidade, a utilização de telhas de fibrocimento apresenta dois aspectos importantes a serem considerados: produção e descarte. A degradação progressiva do cimento nos compósitos cimentícios realça a porosidade e afrouxa fibras minerais das telhas, liberandoas progressivamente no meio ambiente. Assim, fibrocimento não pode ser considerado como um material inerte, devendo ser descartado em aterros sanitários com os devidos cuidados.

As Figuras 2.11 e 2.12 são exemplos de telhas de fibrocimento, com inclinação mínima de $15 \%)$

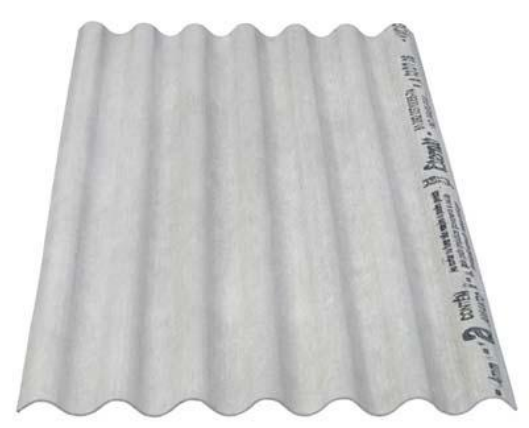

Figura 2.11 - Vogatex (Eternit)

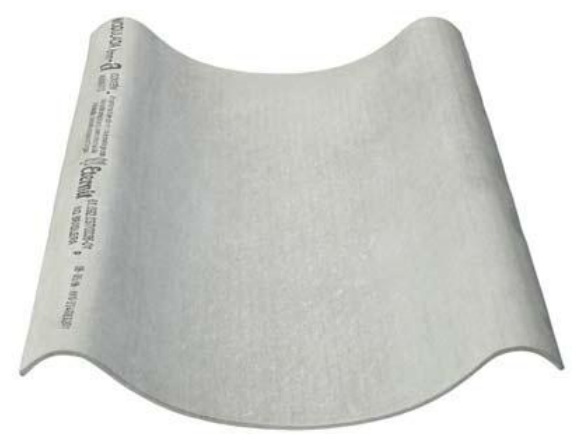

Figura 2.12 - Canalete 49(Eternit)

Disponíveis em: <http://www.forumdaconstrucao.com.br/conteudo.php?a=8\&Cod=448>. Acesso em 14 set. 2015.

\section{6 -Telhas de concreto tégula}

As telhas de concreto estão sendo utilizadas como outra opção para coberturas residenciais. São mais recentes no mercado e tem um leque de opção de cores, o que as transformam em uma beleza arquitetônica ao invés de cumprir somente o papel de cobrir a edificação. Além disso, "as telhas de concreto também são mais fortes e resistentes que as telhas cerâmicas. Essas qualidades são superiores devido aos materiais utilizados e suas formas, que são padronizadas, garantindo um encaixe perfeito e melhor alinhamento", dando assim maior vida útil ao telhado. (Fábio Pires, diretor da Camargo Química). 
Segundo Dobleday Lima Balassa - gerente do Grupo Brasitália, as telhas de concreto se destacam pelo processo de fabricação e também pelos materiais usados: mistura do cimento de alta resistência, areias e agregados (finos, médios e grossos), adicionando água e pigmentos coloridos, que dão coloração às telhas. Depois da mistura bruta pronta, o material é levado à estufa de vapor e moldado no formato desejado.

As telhas de concreto possuem maior impermeabilidade para evitar infiltração de água da chuva, não sobrecarregando a estrutura. O desempenho térmico é outro fator que se sobressai em relação às cerâmicas. As cores claras das telhas de concreto proporcionam maior conforto térmico, principalmente em regiões de muito calor. (PIRES).

Segundo o site www.bonde.com.br, em relação ao peso, as telhas de concreto são mais pesadas (240kgf) que as de cerâmicas (130kgf), porém utilizam menos unidades de telhas para cobrir um telhado, desta forma o peso final de ambas acaba ficando o mesmo. Além disso, tornam o material mais forte evitando quebras durante o transporte e a instalação.

Nas tabelas abaixo, segue um comparativo entre as telhas de concreto e as telhas de cerâmica, indicando os prós e contras de cada uma. Observa-se divergência de opiniões entre cada empresa.

\begin{tabular}{|c|c|}
\hline \multicolumn{2}{|c|}{ Tabela 2.1 - telhas de concreto } \\
\hline PRÓS & CONTRA \\
\hline $\begin{array}{l}\text { Benefício acústico presente nos dois tipos de telha } \\
\text { devido à sua espessura. }\end{array}$ & $\begin{array}{l}\text { São mais pesadas, exigem estrutura de telhado mais } \\
\text { reforçada para sustentá-las. }\end{array}$ \\
\hline $\begin{array}{l}\text { Cláudio Kurth diretor da Área de Telhas Cerâmicas da Anicer } \\
\text { (Associação Nacional da Indústria Cerâmica) }\end{array}$ & $\begin{array}{l}\text { Cláudio Kurth diretor da Área de Telhas Cerâmicas da Anicer } \\
\text { (Associação Nacional da Indústria Cerâmica) }\end{array}$ \\
\hline $\begin{array}{l}\text { A telha de concreto armazena e transfere o calor } \\
\text { para dentro do ambiente. }\end{array}$ & $\begin{array}{l}\text { Telhas de concreto devem ser utilizadas em } \\
\text { coberturas com inclinação mínima de } 30 \% \text {. }\end{array}$ \\
\hline $\begin{array}{l}\text { Cláudio Oliveira Silva gerente de inovação e sustentabilidade da } \\
\text { ABCP (Associação Brasileira de Cimento Portland) }\end{array}$ & $\begin{array}{l}\text { Cláudio Oliveira Silva gerente de inovação e sustentabilidade da } \\
\text { ABCP (Associação Brasileira de Cimento Portland) }\end{array}$ \\
\hline $\begin{array}{l}\text { Dependendo da cor também é um elemento de baixa } \\
\text { condutibilidade térmica. Por serem produzidas } \\
\text { industrialmente, têm dimensões constantes. Têm } \\
\text { baixa perda por serem menos frágeis, se } \\
\text { comparadas às de cerâmica. Também, dependendo } \\
\text { do projeto, podem ser bastante valorizadas } \\
\text { arquitetonicamente. Por fim são mais leves que as } \\
\text { telhas cerâmicas, pois absorvem menos água. } \\
\text { Luiz Tadeu Papaterra L. Mariutti engenheiro da Construtora } \\
\text { Sequencia }\end{array}$ & $\begin{array}{l}\text { Utilizam bastante madeira e, se comparadas às de } \\
\text { cerâmicas, podem ter custo mais elevado } \\
\text { dependendo do local onde se encontra a obra. São } \\
\text { mais difíceis de serem adquiridas fora dos grandes } \\
\text { centros. } \\
\text { Luiz Tadeu Papaterra L. Mariutti engenheiro da Construtora } \\
\text { Sequencia }\end{array}$ \\
\hline $\begin{array}{l}\text { Possui maior resistência; baixa absorção de água. } \\
\text { Portanto, propicia menor proliferação de fungos na } \\
\text { face superior. Os encaixes são perfeitos, o que } \\
\text { proporciona maior segurança quanto à entrada de } \\
\text { água por chuvas de vento. Possui sobreposição } \\
\text { maior, evitando retorno de águas. Grande parte dos }\end{array}$ & $\begin{array}{l}\text { Sua utilização pode ser prejudicada, como ocorre } \\
\text { no caso da telha cerâmica, pela pouca inclinação do } \\
\text { telhado. } \\
\text { Anildo Hoffman engenheiro da Hoffman Telhados }\end{array}$ \\
\hline
\end{tabular}




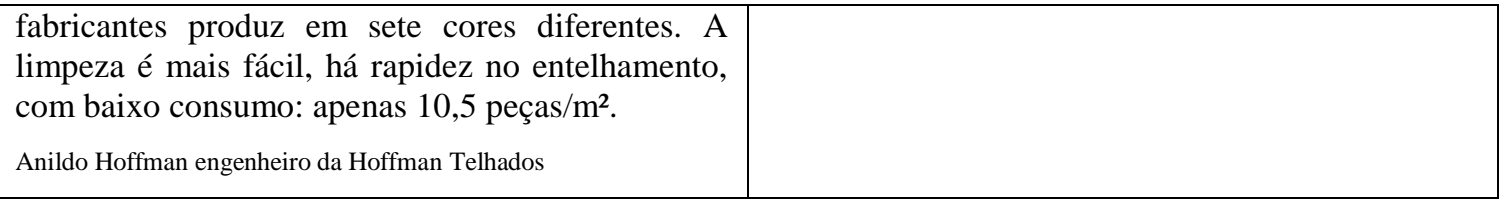

Fornecida pelo site: <http://construcaomercado.pini.com.br/negocios-incorporacao-construcao/127/artigo2997061.aspx>. Acesso em 16 set. 2015.

\begin{tabular}{|c|c|}
\hline \multicolumn{2}{|c|}{ Tabela 2.2 - Telhas cerâmicas } \\
\hline PRÓS & CONTRA \\
\hline $\begin{array}{l}\text { Conforto térmico, acústico, resistência e } \\
\text { durabilidade. Devemos ressaltar também o } \\
\text { embelezamento do telhado pelos tons avermelhados } \\
\text { da cerâmica. Com o uso de telha cerâmica o imóvel } \\
\text { esquenta menos devido a características como } \\
\text { porosidade. } \\
\begin{array}{l}\text { Cláudio Kurth diretor da Área de Telhas Cerâmicas da Anicer } \\
\text { (Associação Nacional da Indústria Cerâmica) }\end{array}\end{array}$ & $\begin{array}{l}\text { A Anicer não expôs nenhum fator contrário ao } \\
\text { produto. } \\
\text { Cláudio Kurth diretor da Área de Telhas Cerâmicas da Anicer } \\
\text { (Associação Nacional da Indústria Cerâmica) }\end{array}$ \\
\hline $\begin{array}{l}\text { A ABCP informou que não se pronuncia sobre esse } \\
\text { tipo de telha. }\end{array}$ & $\begin{array}{l}\text { A ABCP informou que não se pronuncia sobre esse } \\
\text { tipo de telha. }\end{array}$ \\
\hline $\begin{array}{l}\text { Cláudio Oliveira Silva gerente de inovação e sustentabilidade da } \\
\text { ABCP (Associação Brasileira de Cimento Portland) }\end{array}$ & $\begin{array}{l}\text { Cláudio Oliveira Silva gerente de inovação e sustentabilidade da } \\
\text { ABCP (Associação Brasileira de Cimento Portland) }\end{array}$ \\
\hline $\begin{array}{l}\text { Oferecem menor condutibilidade térmica, tornando } \\
\text { os ambientes menos sujeitos à influência da } \\
\text { temperatura externa. Além disso, são mais } \\
\text { charmosas, mesmo quando mais antigas. Por fim } \\
\text { têm custo menor que de coberturas similares e são } \\
\text { fáceis de serem adquiridas. } \\
\text { Luiz Tadeu Papaterra L. Mariutti engenheiro da Construtora } \\
\text { Sequencia }\end{array}$ & $\begin{array}{l}\text { Possui maior resistência; baixa absorção de água. } \\
\text { Portanto, propicia menor proliferação de fungos na } \\
\text { face superior. Os encaixes são perfeitos, o que } \\
\text { proporciona maior segurança quanto à entrada de } \\
\text { água por chuvas de vento. Possui sobreposição } \\
\text { maior, evitando retorno de águas. Grande parte dos } \\
\text { fabricantes produz em sete cores diferentes. A } \\
\text { limpeza é mais fácil, há rapidez no entelhamento, } \\
\text { com baixo consumo: apenas } 10,5 \text { peças } / \mathrm{m}^{2} \text {. } \\
\text { Luiz Tadeu Papaterra L. Mariutti engenheiro da Construtora } \\
\text { Sequencia }\end{array}$ \\
\hline $\begin{array}{l}\text { O único benefício das telhas cerâmicas é o baixo } \\
\text { custo que apresentam em algumas regiões. Isto } \\
\text { pode não acontecer se a obra for muito distante da } \\
\text { fábrica. } \\
\text { Anildo Hoffman engenheiro da Hoffman Telhados }\end{array}$ & $\begin{array}{l}\text { É menos resistente e a aplicação é mais difícil. Vale } \\
\text { ressaltar que um fator que pode limitar o uso da } \\
\text { telha cerâmica, seria a pouca inclinação do telhado, } \\
\text { pois todas exigem acima de } 30 \% \text { ou } 35 \% \text { de } \\
\text { inclinação. } \\
\text { Anildo Hoffman engenheiro da Hoffman Telhado }\end{array}$ \\
\hline
\end{tabular}

Fornecida pelo site: <http://construcaomercado.pini.com.br/negocios-incorporacao-construcao/127/artigo2997061.aspx>. Acesso em 16 set. 2015

Sob os aspectos observados, destacamos as principais vantagens, tendo como fonte o site da tégula (www.tegula.com.br): 
- Alta Impermeabilidade: a telha de concreto tem baixa absorção de água, o que não sobrecarrega a estrutura do telhado e apresenta nervuras na parte inferior que impedem a penetração de água da chuva arrastada pelo vento.

- Diversidade de Cores: as telhas de concreto possuem um leque de cores, podendo ser utilizadas de acordo com o projeto arquitetônico. A tendência é a cor clara para climas quentes e escura para climas mais frios. Assim há diminuição da transferência de calor para a edificação.

- Resistência à Maresia e Granizo: possuem maior resistência às intempéries como abrasão do sal de cidades litorâneas ou impacto de granizo, por exemplo, devido à qualidade de sua composição interna, verniz e acabamentos especiais aplicados na sua superfície.

- Conforto Térmico: as telhas de concreto têm baixo índice de condutividade térmica e alta refletância ao sol, o que garante um melhor conforto térmico.

- Menor Peso/m²: como a colocação das telhas é de uma média de 10,4 telhas por $\mathrm{m}^{2}$, pesando o equivalente a $49 \mathrm{~kg}$, os telhados são mais leves, eliminando o reforço de madeiramento.

- Maior Economia: devido ao fato de suas dimensões e praticidade na colocação das telhas, é possível cobrir uma área maior em menor tempo e com menores custos de instalação.

- Maior Resistência: os materiais são altamente resistentes e possuem uma avançada tecnologia em sua produção, possibilitando uma resistência superior a $250 \mathrm{~kg}$. Com isso, elimina a quebra de telhas durante a instalação e aumentando a vida útil do telhado.

- Encaixes Perfeitos: as telhas de concreto possuem um encaixe perfeito, tendo um telhado sempre alinhado, pois são produzidas em esteiras tolerâncias (esteiras transportadoras de saída com velocidade constante).

Salienta-se ainda que a marca Tégula conseguiu o Selo Procel (Programa Nacional de Conservação de Energia Elétrica) nos produtos reservatório térmicos e sistema de aquecimento solar, apresentando os melhores níveis de eficiência energética dentro de cada categoria citada. 


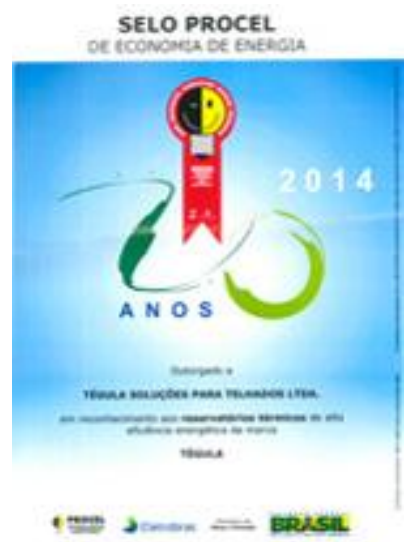

Figura 2.13 - Selo Procel

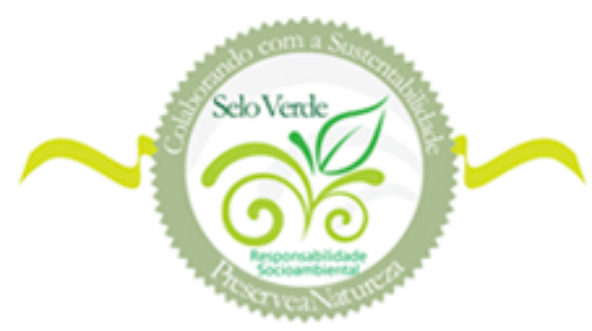

Figura 2.14 - Selo Verde

Disponíveis em: <www.tegula.com.br>. Acesso em 20 set. 2015.

A Tégula ainda foi certificada com o Selo Verde, o que qualifica a empresa como sustentável e ativa na preservação do meio ambiente. Além disso, essa certificação consolida a Tégula como uma organização pioneira e referência em sustentabilidade no segmento, sinalizando comprometimento em longo prazo para acionistas e fornecedores. (www.tegula.com.br)
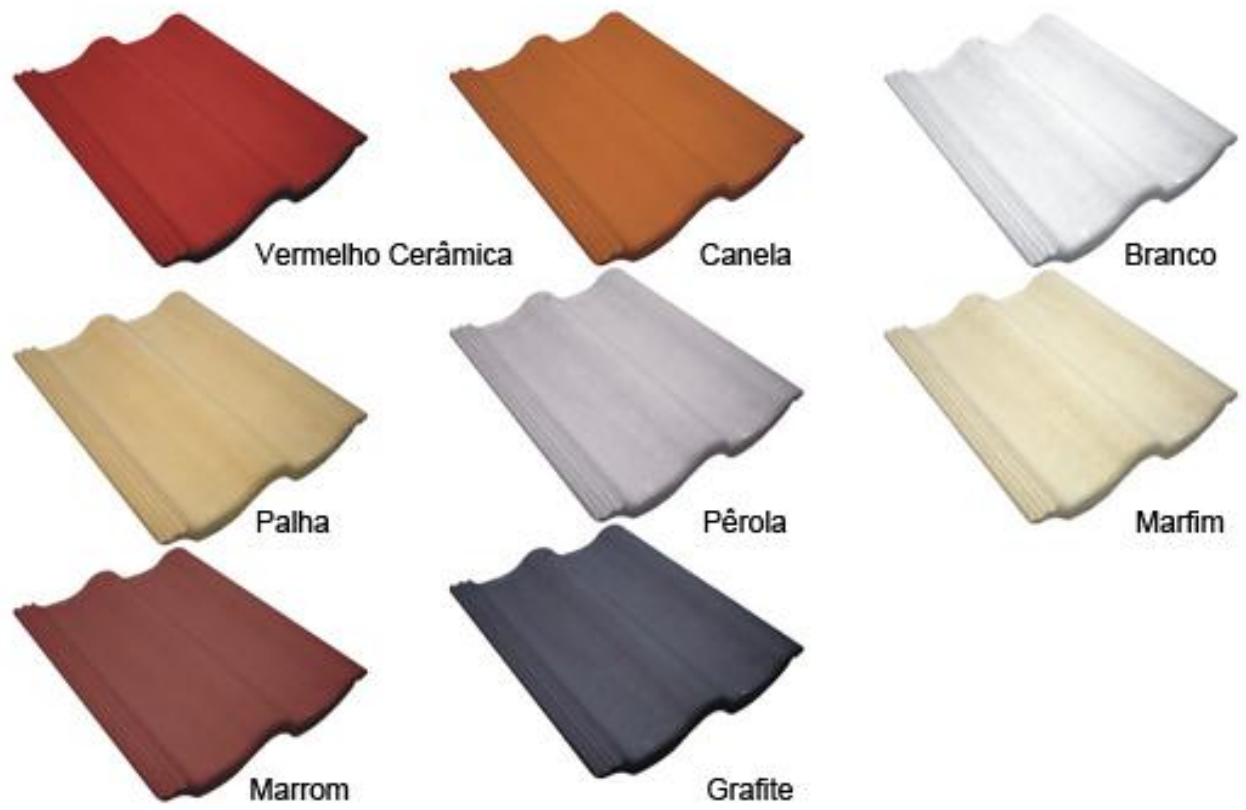

Figura 2.15 - Telhas de Concreto Coloridas.

Disponível em nivalcoberturas.com.br, em 22/09/2015

A escolha das telhas deu-se após uma ampla pesquisa na área de coberturas utilizadas na construção civil. Ainda não existem muitas opções ecológicas disponíveis no mercado, pois o Brasil está crescendo nesta área. 


\section{CAPÍTULO 3}

\section{CRITÉRIOS DE AVALIAÇÃO DAS TELHAS}

É cada vez maior a preocupação em realizar construções em harmonia com a natureza, com baixo impacto ambiental e custos operacionais reduzidos, priorizando técnicas construtivas sustentáveis, matérias-primas naturais, recicláveis e de fontes renováveis, caminho para que as cidades se tornem mais sustentáveis. As preocupações com os impactos ambientais gerados pelos edifícios, durante as fases de planejamento e construção ou durante a operação, são cada vez maiores. Hoje em dia, como já mencionado na introdução desta dissertação, basicamente cada país europeu - além de Estados Unidos, Canadá, Austrália, Japão e Hong Kong - possui um sistema de avaliação e classificação de desempenho ambiental de edifícios (http://www.seer.ufrgs.br/, avaliação do ambiente construído). Os diversos selos existentes e principalmente os aqui estudados, possuem, no contexto geral, as avaliações pretendidas baseadas em ferramentas vareáveis, porém com um único propósito: a aplicação da sustentabilidade nas edificações. Em alguns dos selos, como veremos a seguir, o mecanismo de análise inclui desde a elaboração do projeto até a avaliação pós-ocupação. A grande maioria dos sistemas adequa-se melhor à avaliação de novos projetos ou novas obras, pois possuem maior facilidade em preencher os quesitos exigidos. Estes sistemas podem ser divididos em duas categorias distintas. Na primeira categoria encontram-se os selos que são orientados para que os esforços dispensados para melhorar a qualidade ambiental destes projetos, da execução e gerenciamento operacional tenham reconhecimento do mercado. Neste caso a estrutura é simples e está atrelada a algum tipo de certificação de desempenho. Este é o caso do BREEAM (BALDWIN et al.,1990; BALDWIN et al., 1998), do HK- BEAM (CENTRE OF ENVIRONMENTAL TECHNOLOGY, 1999), do LEED тм (USGBC, 1999) e do CSDB ESCALE (NIBEL et al., 2000). Já na segunda categoria, o foco da aviação é a pesquisa, como o BEPAC ${ }^{2}$ (COLE; ROUSSEAU; THEAKER, 1993) e o seu sucessor o GBC (COLE; LARSON, 2000). Neste caso em questão, a abordagem é feita com ênfase no desenvolvimento de uma metodologia mais abrangente que possa orientar novas pesquisas. Muitos desses selos internacionais verificam os recursos consumidos, as emissões de carbono e os resíduos gerados pelas edificações, bem como o conforto e a saúde das pessoas que convivem ali. Para isso, é feita uma avaliação sobre o grau de sustentabilidade dos edifícios, baseada em critérios específicos de cada selo (planetasustentavel.abril.com.br). 


\subsection{BREEAM}

Sobre alguns dos critérios, o Building Establishement Environment Assessment Method (BREEAM) que foi desenvolvido no Reino Unido por pesquisadores do BRE e do setor privado (BALDWIN et al.,1990) é o primeiro e mais conhecido sistema de avaliação de desenvolvimento ambiental (assessment and rating system). É baseado em análise documental e inclui aspectos de gestão ambiental na concessão dos créditos. Feito através de um checklist e verificado o atendimento de itens mínimos de desempenho, projeto e operação dos edifícios e atribuído créditos ambientais, que são ponderados e após análise chega-se a um número único. Atendida uma quantidade mínima de créditos, este índice habilita à certificação em uma das classes de desempenho do BREEAM e permite comparação relativa entre os edifícios certificados pelo sistema.

O empreendimento submetido ao processo de avaliação recebe uma pontuação conforme seu desempenho, podendo ser: Unclassifield (desclassificado: resultado<30), Pass (aprovado: resultado $\geq 30$ ), Good (bom: resultado $\geq 45$ ), Very Good (muito bom: resultado $\geq 55$ ), Excellent (excelente: resultado $\geq 70$ ) e Outstanding (excepcional: resultado $\geq 85$ ). Cada nível apresentado possui um valor mínimo de créditos a serem alcançados, chamados créditos mandatórios, e a qualificação da construção fica de acordo com a quantidade de pontos obtidos.

Os atributos são:

- Gestão da Construção: gerenciamento das diretrizes gerais, dos procedimentos.

- Saúde e Bem-Estar: questões internas e externas ao empreendimento que afetam a saúde e bem-estar do indivíduo.

- Consumo de Energia: gestão de energia e dióxido de carbono.

- Transporte: relação transporte e $\mathrm{CO} 2$ e fatores relacionados à localização.

- Consumo de Água: consumo e uso eficiente da água.

- Materiais: impacto ambiental dos materiais do edifício incluindo a análise do ciclo de vida.

- Gestão de Resíduos: promover a eficiência dos recursos através da gestão eficaz e redução de resíduos da construção. 
- Utilização de Terreno e Ecologia: conservação e aumento do valor ecológico do terreno e uso das terras, áreas verdes e contaminadas.

- Contaminação /Poluição: poluição do ar e da água.

A Tabela 3.1 apresenta os atributos e critérios de avaliação previstos no BREEAM.

Tabela 3.1 - Resumo BREEAM New Construction.

\begin{tabular}{|c|c|c|c|}
\hline 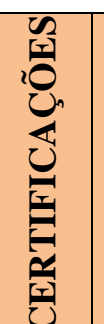 & 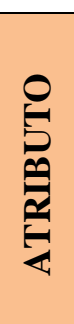 & $\begin{array}{l}\text { CRITÉRIOS DE } \\
\text { AVALIAÇÃO }\end{array}$ & OBJETIVO \\
\hline \multirow{7}{*}{ 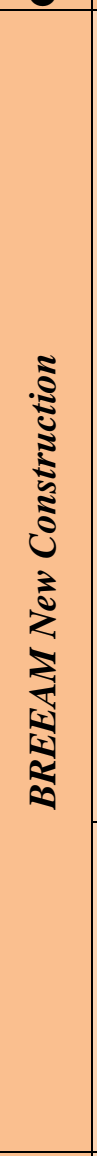 } & \multirow{5}{*}{ 密 } & Compras sustentáveis & $\begin{array}{l}\text { Para garantir a entrega de um produto funcional e } \\
\text { sustentável projetado e construído de acordo com as } \\
\text { expectativas de desempenho. }\end{array}$ \\
\hline & & Práticas sustentáveis da construção & $\begin{array}{l}\text { Para reconhecer e incentivar a construção de locais } \\
\text { geridos de forma ambientalmente e socialmente } \\
\text { responsável e confiável. }\end{array}$ \\
\hline & & Impactos da construção no solo & $\begin{array}{l}\text { Para reconhecer e incentivar canteiros de obras geridos } \\
\text { de forma ambientalmente saudável em termos de } \\
\text { consumo de recursos de energia, uso e poluição. }\end{array}$ \\
\hline & & A participação dos interessados & $\begin{array}{l}\text { Para projetar, planejar e entregar edifícios funcionais e } \\
\text { acessíveis inclusive de acordo com usuários de } \\
\text { construção atuais e futuras e outras partes interessadas. }\end{array}$ \\
\hline & & $\begin{array}{l}\text { Custo do ciclo de vida e planejamento } \\
\text { de vida útil }\end{array}$ & $\begin{array}{l}\text { Para reconhecer e incentivar o custo do ciclo de vida e } \\
\text { planejamento do serviço, a fim de melhorar a } \\
\text { especificação do projeto, e através da manutenção e } \\
\text { operação. }\end{array}$ \\
\hline & \multirow{2}{*}{ 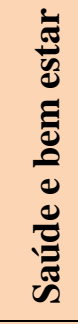 } & Conforto visual & $\begin{array}{l}\text { Para garantir a iluminação natural e artificial e o } \\
\text { controle dos ocupantes, são considerados na fase de } \\
\text { projeto para garantir o melhor desempenho visual e } \\
\text { conforto para os ocupantes do edifício. }\end{array}$ \\
\hline & & Qualidade interna do ar & $\begin{array}{l}\text { Para reconhecer e incentivar um ambiente interno } \\
\text { saudável através da especificação e instalação de } \\
\text { ventilação, equipamentos e acabamentos adequados. }\end{array}$ \\
\hline \multirow{3}{*}{ 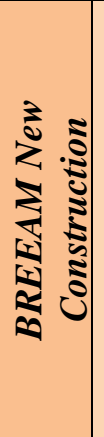 } & \multirow{3}{*}{ 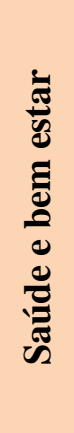 } & Conforto Térmico & $\begin{array}{l}\text { Para assegurar--se de que os níveis apropriados do } \\
\text { conforto térmico estejam conseguidos com o projeto, e } \\
\text { os controles são selecionados para manter um conforto } \\
\text { térmico para os ocupantes do edifício. }\end{array}$ \\
\hline & & Qualidade da água & $\begin{array}{l}\text { Para minimizar o risco de contaminação da água no } \\
\text { edifício e garantir o fornecimento de fontes limpas e } \\
\text { frescas de água para os usuários do edifício. }\end{array}$ \\
\hline & & Performance acústica & $\begin{array}{l}\text { Para garantir o conforto acústico dos edifícios, incluindo } \\
\text { isolamento acústico e cumprimento das normas } \\
\text { adequadas para esta finalidade. }\end{array}$ \\
\hline
\end{tabular}




\begin{tabular}{|c|c|c|c|}
\hline & & Saúde e segurança & $\begin{array}{l}\text { Para reconhecer e incentivar medidas de design eficazes } \\
\text { que promovam o baixo risco, o acesso seguro e uso do } \\
\text { edifício. }\end{array}$ \\
\hline & \multirow{9}{*}{ 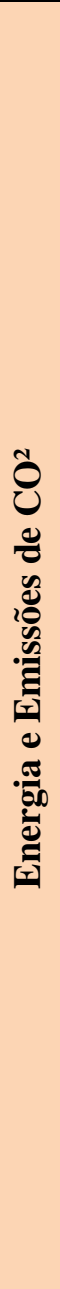 } & Redução das emissões de CO2 & $\begin{array}{l}\text { Para reconhecer e incentivar edifícios projetados para } \\
\text { minimizar a demanda de energia operacional, consumo } \\
\text { e emissões de } \mathrm{CO} 2 \text {. }\end{array}$ \\
\hline & & Monitoramento de energia & $\begin{array}{l}\text { Para reconhecer e incentivar a instalação de energia } \\
\text { sub--medição que facilita o monitoramento do consumo } \\
\text { de energia operacional. }\end{array}$ \\
\hline & & Iluminação externa & $\begin{array}{l}\text { Para reconhecer e incentivar a especificação de } \\
\text { eficiência energética candeeiros para áreas externas do } \\
\text { desenvolvimento. }\end{array}$ \\
\hline & & Baixo e zero emissões de carbono & $\begin{array}{l}\text { Para reduzir as emissões de carbono e poluição } \\
\text { atmosférica, incentivando a geração de energia local a } \\
\text { partir de fontes renováveis para abastecer uma } \\
\text { proporção significativa da demanda de energia. }\end{array}$ \\
\hline & & $\begin{array}{c}\text { Sistemas de energia eficientes de } \\
\text { refrigeração }\end{array}$ & $\begin{array}{l}\text { Para reconhecer e incentivar a instalação de sistemas de } \\
\text { energia eficientes de refrigeração, portanto, reduzir as } \\
\text { emissões de efeito } \\
\text { operacionais de gases resultantes do uso de energia do } \\
\text { sistema. }\end{array}$ \\
\hline & & $\begin{array}{l}\text { Energia Eficiente em sistemas de } \\
\text { transporte }\end{array}$ & $\begin{array}{l}\text { Para reconhecer e incentivar a especificação de sistemas } \\
\text { energeticamente eficientes de transporte. }\end{array}$ \\
\hline & & $\begin{array}{c}\text { Incentivo a pesquisas para redução da } \\
\text { emissão de } \mathrm{CO}^{2}\end{array}$ & $\begin{array}{l}\text { Para reconhecer e incentivar as áreas de laboratório, que } \\
\text { são projetados para minimizar as emissões de CO2 } \\
\text { associadas ao seu consumo de energia operacional. }\end{array}$ \\
\hline & & Equipamentos de energia eficiente & $\begin{array}{l}\text { Para reconhecer e incentivar a aquisição de } \\
\text { equipamentos energeticamente eficientes para garantir o } \\
\text { melhor desempenho e economia de energia em } \\
\text { operação. }\end{array}$ \\
\hline & & $\begin{array}{l}\text { Propor espaços com menos gasto } \\
\text { energético para secar roupas }\end{array}$ & $\begin{array}{l}\text { Para fornecer uma energia reduzida significa de secagem } \\
\text { de roupa. }\end{array}$ \\
\hline & 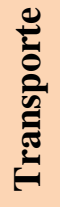 & Acessibilidade ao transporte público & $\begin{array}{l}\text { Para reconhecer e incentivar o desenvolvimento de boas } \\
\text { redes de transportes públicos nas proximidades, } \\
\text { ajudando assim a reduzir o transporte relacionado à } \\
\text { poluição e congestionamentos. }\end{array}$ \\
\hline \multirow{4}{*}{ 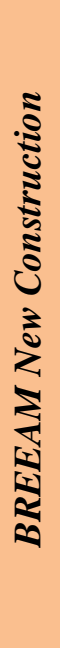 } & \multirow{4}{*}{ 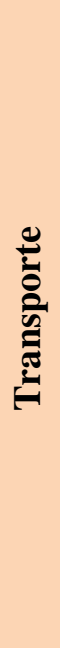 } & $\begin{array}{l}\text { Proximidade, boa localização reduzindo } \\
\text { longos trajetos. }\end{array}$ & $\begin{array}{l}\text { Para incentivar e premiar um prédio que está localizado } \\
\text { próximo às amenidades locais, reduzindo assim a } \\
\text { necessidade de viagens longas ou de múltiplas viagens. }\end{array}$ \\
\hline & & Facilidade para os ciclistas & $\begin{array}{l}\text { Para incentivar construções para os ciclistas, garantindo } \\
\text { o fornecimento adequado de instalações aos ciclistas. }\end{array}$ \\
\hline & & Capacidade máxima de estacionamento & $\begin{array}{l}\text { Para incentivar o uso de meios alternativos de transporte } \\
\text { p/ outro edifício, ajudando assim a reduzir as emissões } \\
\text { de gases dos transportes e congestionamento de tráfego. }\end{array}$ \\
\hline & & Planejamento de trajeto & $\begin{array}{l}\text { Para reconhecer a importância dada para acomodar uma } \\
\text { variedade de opções de viagem para os usuários, } \\
\text { incentivando assim a redução da dependência do usuário } \\
\text { em formas de viagens que têm o maior impacto } \\
\text { ambiental. }\end{array}$ \\
\hline
\end{tabular}




\begin{tabular}{|c|c|c|c|}
\hline & \multirow{4}{*}{ 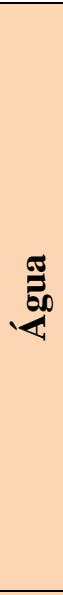 } & $\begin{array}{c}\text { Redução do consumo de água potável } \\
\text { para outros fins }\end{array}$ & $\begin{array}{l}\text { Para reduzir o consumo de água potável para uso } \\
\text { sanitário em novos edifícios a partir de todas as fontes } \\
\text { através da utilização de componentes de água e sistemas } \\
\text { eficientes de reciclagem de água. }\end{array}$ \\
\hline & & Monitoramento da água & $\begin{array}{l}\text { Para garantir o monitoramento e gerenciamento do } \\
\text { consumo de água e, portanto, incentivar a redução do } \\
\text { consumo de água. }\end{array}$ \\
\hline & & $\begin{array}{c}\text { Detecção de vazamento de água e } \\
\text { prevenção }\end{array}$ & $\begin{array}{l}\text { Para reduzir o impacto dos vazamentos de água que } \\
\text { podem de outra maneira podem passar despercebidos. }\end{array}$ \\
\hline & & Equipamento eficiente da água & $\begin{array}{l}\text { Para reduzir o consumo de água não regulamentada, } \\
\text { incentivando especificação de equipamento eficiente da } \\
\text { água. }\end{array}$ \\
\hline & \multirow{4}{*}{ 絖 } & Impacto do ciclo de vida & $\begin{array}{l}\text { Para reconhecer e incentivar o uso de materiais de } \\
\text { construção com baixo impacto ambiental (incluindo } \\
\text { carbono incorporado) sobre o ciclo de vida do edifício. } \\
\text { Para reconhecer e incentivar a especificação de materiais } \\
\text { para proteção de fronteira e externas superfícies duras } \\
\text { que têm um baixo impacto ambiental, tendo em conta o } \\
\text { ciclo de vida dos materiais utilizados. }\end{array}$ \\
\hline & & $\begin{array}{l}\text { Área permeável, afastamentos e } \\
\text { cobertura verde. }\end{array}$ & $\begin{array}{l}\text { Para reconhecer e incentivar a especificação de materiais } \\
\text { para proteção de fronteira e externas superfícies duras } \\
\text { que têm um baixo impacto ambiental, tendo em conta o } \\
\text { ciclo de vida dos materiais utilizados. }\end{array}$ \\
\hline & & Responsável especificação de matérias & $\begin{array}{l}\text { Para reconhecer e incentivar a especificação de materiais } \\
\text { de origem de forma responsável para os elementos chave } \\
\text { de construção. }\end{array}$ \\
\hline & & Isolamento térmico & $\begin{array}{l}\text { Para reconhecer e incentivar a especificação de materiais } \\
\text { de origem de forma responsável para os elementos chave } \\
\text { de construção. Para reconhecer e incentivar o uso de } \\
\text { isolamento térmico, que tem uma relação de baixo } \\
\text { impacto ambiental incorporado às suas propriedades } \\
\text { térmicas e foi responsável origem. }\end{array}$ \\
\hline \multirow{5}{*}{ 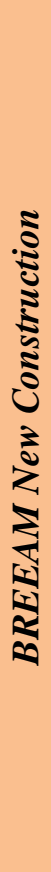 } & 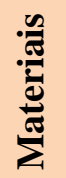 & Durabilidade & $\begin{array}{l}\text { Para reconhecer e incentivar a proteção adequada dos } \\
\text { elementos expostos do edifício e da paisagem, } \\
\text { minimizando assim a frequência de substituição e } \\
\text { maximizando a otimização de materiais. }\end{array}$ \\
\hline & \multirow{4}{*}{ 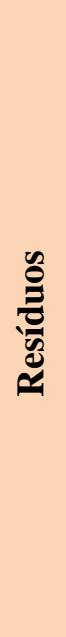 } & Gestão de resíduos de construção & $\begin{array}{l}\text { Para promover a eficiência dos recursos através da } \\
\text { gestão eficaz e redução de resíduos de construção. }\end{array}$ \\
\hline & & Agregados reciclados & $\begin{array}{l}\text { Para reconhecer e incentivar o uso de agregados } \\
\text { reciclados e secundário, reduzindo assim a demanda por } \\
\text { material virgem e otimizando a eficiência dos materiais } \\
\text { de construção. }\end{array}$ \\
\hline & & Resíduos operacionais & $\begin{array}{l}\text { Para reconhecer e incentivar o fornecimento de } \\
\text { instalações de armazenamento dedicado para um } \\
\text { edifício operacional relacionados com fluxos de } \\
\text { resíduos recicláveis, de modo que os resíduos são } \\
\text { desviados dos aterros ou incineração. }\end{array}$ \\
\hline & & Pisos e forros aprovados pelo cliente & $\begin{array}{l}\text { Para incentivar a especificação e instalação de piso e } \\
\text { tetos selecionados pelo ocupante do edifício e, portanto, } \\
\text { evitar o desperdício de materiais. }\end{array}$ \\
\hline
\end{tabular}




\begin{tabular}{|c|c|c|c|}
\hline & \multirow{5}{*}{ 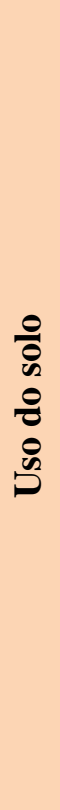 } & A escolha do local & $\begin{array}{l}\text { Para incentivar o uso da terra utilizada anteriormente e / } \\
\text { ou contaminadas e evitar terra que não tenha sido } \\
\text { previamente usada. }\end{array}$ \\
\hline & & $\begin{array}{l}\text { Valor ecológico do local e proteção dos } \\
\text { recursos ecológicos }\end{array}$ & $\begin{array}{l}\text { Para incentivar o desenvolvimento em terras que já tem } \\
\text { um valor limitado para a fauna e para proteger existentes } \\
\text { características ecológicas de danos substanciais durante } \\
\text { a preparação do local e na conclusão das obras de } \\
\text { construção. }\end{array}$ \\
\hline & & Mitigar o impacto ecológico & $\begin{array}{l}\text { Para minimizar o impacto de um desenvolvimento do } \\
\text { edifício na ecologia existente do local. }\end{array}$ \\
\hline & & Melhorias na área local & $\begin{array}{l}\text { Para reconhecer e incentivar as ações feitas exame para } \\
\text { manter e realçar o valor ecológico do local em } \\
\text { consequência do desenvolvimento. }\end{array}$ \\
\hline & & $\begin{array}{l}\text { Impacto em longo prazo sobre a } \\
\text { biodiversidade }\end{array}$ & $\begin{array}{l}\text { Para minimizar o impacto em longo prazo do } \\
\text { desenvolvimento no local e na biodiversidade da área } \\
\text { circunvizinha. }\end{array}$ \\
\hline & \multirow{3}{*}{ 胥 } & Impacto dos gases dos ares refrigerados & $\begin{array}{l}\text { Para reduzir o nível de emissões de gases de efeito estufa } \\
\text { decorrentes do vazamento de fluidos dos refrigeradores } \\
\text { de sistemas de construção. }\end{array}$ \\
\hline & & Reduzida emissão de CO2 & $\begin{array}{l}\text { Para encorajar o fornecimento de calor e / ou } \\
\text { refrigeração partir de um sistema que minimiza as } \\
\text { emissões de } \mathrm{CO} 2 \mathrm{e} \text {, portanto, reduz a poluição do meio } \\
\text { ambiente local. }\end{array}$ \\
\hline & & Água escoamento superficial & $\begin{array}{l}\text { Para evitar, reduzir e retardar o escoamento de chuva } \\
\text { para sistema de esgotos, minimizando assim o risco de } \\
\text { inundações localizadas dentro e fora do local, à poluição } \\
\text { do curso de água e outros danos ambientais. }\end{array}$ \\
\hline \multirow{2}{*}{ 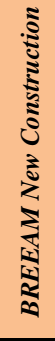 } & \multirow[t]{2}{*}{ 葛 } & Redução da poluição luminosa noturna & $\begin{array}{l}\text { Para garantir que a luz exterior seja concentrada nas } \\
\text { áreas apropriadas e que a iluminação de cima seja } \\
\text { minimizada, reduzindo a poluição da luz desnecessária, } \\
\text { o consumo de energia e os efeitos nocivos para as } \\
\text { propriedades vizinhas. }\end{array}$ \\
\hline & & Atenuação de ruído & $\begin{array}{l}\text { Para reduzir a probabilidade de ruído do novo } \\
\text { desenvolvimento que afeta edifícios próximos e } \\
\text { sensíveis ao ruído. }\end{array}$ \\
\hline
\end{tabular}

Fonte: LANNOY,2013.

\subsection{GBC e GBC Brasil}

O Geen Building Challenge (GBC) é um consórcio internacional com o objetivo de desenvolver um novo método para avaliar o desempenho ambiental de edifícios, fornecendo um protocolo de avaliação com uma base comum, porém capaz de respeitar diversidades técnicas e regionais (COLE; LARSSON,2000). É caracterizado por ciclos sucessivos de pesquisa e difusão de resultados. O GBC procura diferenciar-se com uma nova geração de sistemas de avaliação, desenvolvida especificamente para refletir as diferentes prioridades, 
tecnologias, tradições construtivas e valores culturais de diversos países ou até mesmo regiões diferentes num mesmo país. Neste caso, a pontuação final acaba sendo uma consequência da investigação principal, que é o desenvolvimento de uma metodologia de avaliação que possa ser incrementada ou simplificada para atender as demandas de determinado local.

No Brasil, selo é conhecido como Green Building Council Brasil (GBC Brasil). Esta ONG, que surgiu para auxiliar no desenvolvimento da indústria de construção sustentável no país, utilizando as forças de mercado para conduzir a adoção de práticas de Green Building em um processo integrado de concepção, construção e operação de edificações e espaços construídos. Fundado em dezembro de 2007 por Thassanee Wanick, hoje é um dos 14 membros do World Green Building Council (entidade supranacional que regula e incentiva a criação de Conselhos Nacionais como forma de promover mundialmente tecnologias, iniciativas e operações sustentáveis na construção civil). O GBC Brasil tem como função atuar na disseminação do conhecimento sobre as construções verdes, capacitando tecnicamente os profissionais de várias áreas da construção civil, integrando ainda o mercado da construção civil e as organizações governamentais e não governamentais. Trabalha também na divulgação das melhores práticas adotadas, o que inclui materiais, tecnologias, projetos, procedimentos operacionais, assim como promover o LEED (Leadership in Energy \& Environmental Design) no Brasil. O GBC Brasil ainda tem como meta integrar todos os agentes do mercado de maneira a construir um ambiente favorável à construção, urbanização e desenvolvimento sustentável.

Os estudos dos selos de certificação como o LEED (Leadership in Energy and Environmental Design), que é uma certificação para edifícios sustentáveis, concedida pelo GBC Brasil (Green Building Council Brasil), órgão responsável pelo selo no país, de acordo com os critérios de racionalização de recursos (energia, água etc.) atendidos por um edifício e o AQUA (Alta Qualidade Ambiental) que também utiliza critérios de certificação de qualificação de edificação sustentável e que é um sistema brasileiro são meios de análise ambiental. Ressalvase ainda a importância do consentimento dos aspectos ambientais de uma construção, que devem ser tão relevantes quanto os aspectos técnicos e econômicos. O reaproveitamento dos materiais, o uso da tecnologia de baixo impacto como a solar e repensando o uso da água e da energia, aplicando técnicas de conforto ambiental, são alguns dos fatores que definem um projeto como sustentável. Aliado a eles, também é relevante considerar a estética e o senso de conforto como parte do contexto cultural de seus usuários. 


\subsection{LEED}

Em relação ao Leadership in Energy and Environment Design (LEED), os trabalhos para seu desenvolvimento foram iniciados em 1996 nos Estados Unidos com o propósito de facilitar a transferência de conceitos de construção ambientalmente responsável para os profissionais e para a indústria de construção americana. O desempenho ambiental da edificação é avaliado de forma global, por todo o período de seus ciclos de vida, numa tentativa de considerar os preceitos essenciais do que constituiria um "green building". O método de avaliação pelo LEED é o cumprimento de uma gama de pré-requisitos. Tendo todos esses requisitos cumpridos, passa-se à etapa de classificação do desempenho, em que a atribuição de créditos indica o grau de conformidade do atendimento aos itens avaliados. O LEED é um documento consensual, aprovado pelas 13 categorias da indústria de construção representadas no conselho gestor do esquema. Sendo também constituído por um checklist que atribui créditos para o atendimento de critérios pré-estabelecidos, basicamente ações de projeto, construção ou gerenciamento que contribuam para reduzir os impactos ambientais de edifícios. O LEED for Homes faz parte desse estudo e objeto e análise do trabalho em questão. O LEED for Homes é um sistema de avaliação de casas verdes (casas que utilizam menos energia, água e recursos naturais e que geram menos resíduos) para assegurar que as casas sejam projetadas e construídas com recursos energéticos suficientes e saudáveis para os ocupantes. É feito através de testes de desempenho especificado e inspeções. Foi lançado em dezembro de 2007 e é um dos métodos de análise mais utilizado nos dias atuais. Os benefícios do uso do LEED for Homes vão desde a economia de energia e água aos benefícios ambientais como redução de gases e exposições a mofo, bolor e fungos prejudiciais à saúde. Foi desenvolvido para promover a transformação da indústria de construção de casas para práticas mais sustentáveis.

Os benefícios da certificação são, conforme GBC/Brasil (www.gbcbrasil.org.br):

\section{ECONÔMICOS:}

- Diminuição dos custos operacionais.

- Diminuição dos riscos regulatórios.

- Valorização do imóvel para revenda ou arrendamento.

- Aumento na velocidade de ocupação. 
- Modernização e menor obsolescência da edificação.

- Aumento da retenção.

\section{SOCIAIS:}

- Melhora na segurança e priorização da saúde dos trabalhadores ocupantes.

- Inclusão social e aumento do senso de comunidade.

- Capacitação profissional.

- Conscientização de trabalhadores e usuários.

- Aumento da produtividade do funcionário; melhora na recuperação de pacientes (em hospitais); melhora no desempenho de alunos (em escolas); aumento no ímpeto de compra de consumidores (em comércios).

- Incentivo à fornecedores com maiores responsabilidades socioambientais.

- Aumento da satisfação e bem-estar dos usuários.

- Estímulo a políticas públicas de fomento a Construção Sustentável.

\section{AMBIENTAIS:}

- Uso racional e redução da extração dos recursos naturais.

- Redução do consumo de água e energia.

- Implantação consciente e ordenada.

- Mitigação dos efeitos das mudanças climáticas.

- Redução, tratamento e reuso dos resíduos da construção e operação. 
Este sistema de avaliação foi, a priori, desenvolvido para edificações novas e, com a demanda e evolução na construção, novas versões foram desenvolvidas. São disponibilizados os seguintes tipos de LEED no Brasil, conforme observado nas Tabelas 3.2 e 3.3:

Tabela 3.2 - Categorização dos tipos de LEED no Brasil.

\begin{tabular}{|l|l|}
\hline \multicolumn{1}{|c|}{ CATEGORIAS } & \multicolumn{1}{|c|}{ DESCRIÇÃO } \\
\hline LEED NC & $\begin{array}{l}\text { Novas construções e grandes } \\
\text { projetos de renovação }\end{array}$ \\
\hline LEED ND & $\begin{array}{l}\text { Desenvolvimento de bairro } \\
\text { (localidades }\end{array}$ \\
\hline LEED CS & $\begin{array}{l}\text { Projetos da envoltória e parte } \\
\text { central do edifício }\end{array}$ \\
\hline LEED Retail NC e CI & Lojas de varejo \\
\hline LEED Healthcare & Unidades de Saúde \\
\hline LEED EB_OM & $\begin{array}{l}\text { Operação de manutenção de } \\
\text { edifícios existentes }\end{array}$ \\
\hline LEED Schools & Escolas \\
\hline LEED CI & $\begin{array}{l}\text { Projetos de interiores e edifícios } \\
\text { comerciais }\end{array}$ \\
\hline LEED GBC Brasil Casa & Em desenvolvimento \\
\hline
\end{tabular}

Fonte: 〈http://pt.wikipedia.org/wiki/Leadership_in_Energy_and_Environmental_Design〉. Disponível em 17 nov. 2014 
Tabela 3.3 - Tipologias e abrangências do LEED Brasil.

\begin{tabular}{|c|c|}
\hline \multicolumn{2}{|r|}{ Entenda o LEED (versão 2009) } \\
\hline Tipologia & Abrangência \\
\hline Novas Construções (NC) & $\begin{array}{l}\text { Destina-se a novas construções e grandes reformas de projetos comerciais e } \\
\text { institucionais de alto desempenho, incluindo edifícios de escritórios, edifícios altos, } \\
\text { hotéis, edifícios residenciais, edifícios governamentais, instalações recreativas, } \\
\text { fábricas, bibliotecas, museus ou igrejas. }\end{array}$ \\
\hline $\begin{array}{l}\text { Edifícios existentes: } \\
\text { operação e manutenção } \\
\text { (EB-O\&M) }\end{array}$ & $\begin{array}{l}\text { Destina-se a edifícios já existentes buscando a certificação pela primeira vez ou } \\
\text { aqueles já certificados nas tipologias SCH, CN ou CS. Auxilia proprietários e } \\
\text { operadores nas medições de operações como o objetivo de maximizar a eficiência } \\
\text { operacional e estabelece caminhos para solucionar problemas relacionados à limpeza } \\
\text { e manutenção (incluindo uso de produtos químicos), manutenção exterior e } \\
\text { atualização de sistema de reciclagem. }\end{array}$ \\
\hline Interiores Comerciais (CI) & $\begin{array}{l}\text { Certificação para interiores verdes de alto desempenho e abrange a qualidade } \\
\text { ambiental para que os ambientes de trabalho sejam saudáveis e favoreçam a } \\
\text { produtividade. Sua aplicação promove a redução do impacto ambiental, torna a } \\
\text { operação dos espaços menos dispendiosa e de mais fácil operação. Ajuda designers } \\
\text { e usuários que nem sempre têm controle sobre todas as operações do edifício, a } \\
\text { fazerem escolhas sustentáveis. }\end{array}$ \\
\hline $\begin{array}{c}\text { Core \& shell }(\mathrm{CS}) \text { - núcleo } \\
\text { de fechamentos }\end{array}$ & $\begin{array}{l}\text { Abrange núcleos, fechamentos e considera também a tecnologia de conforto } \\
\text { ambiental da edificação. Destina-se a projetos desenvolvidos para o mercado nos } \\
\text { quais os projetistas não têm o controle sobre as intervenções no ambiente que serão } \\
\text { feitas pelos usuários, como, por exemplo, edifícios de pequenos escritórios ou } \\
\text { consultórios. Se a previsão é de o proprietário ou locatário ocupar a maior parte do } \\
\text { edifício, recomenda-se utilizar o LEED NC. Aplica-se também a shopping centers. }\end{array}$ \\
\hline Escolas (SCH) & $\begin{array}{l}\text { Reconhece o caráter único da concepção e construção de escolas. É baseado no } \\
\text { LEED NC e aborda questões como saúde infantil, acústica da sala de aula, plano } \\
\text { diretor e avaliação do ambiente local. }\end{array}$ \\
\hline Varejo & $\begin{array}{l}\text { É composto por dois sistemas de classificação destinados a novas construções ou } \\
\text { grandes reformas e aos ambientes internos. É o sistema de classificação indicado } \\
\text { para bancos, restaurantes, grandes magazines e lojas em geral. }\end{array}$ \\
\hline Saúde (HC) & $\begin{array}{l}\text { Orienta a concepção e a construção de grandes obras de renovação de edifícios } \\
\text { destinados à saúde. Pode ser aplicado em instalações ambulatoriais, de internação, } \\
\text { consultórios, laboratórios e centros de formação médica ou de pesquisa, entre outras } \\
\text { possibilidades. }\end{array}$ \\
\hline $\begin{array}{l}\text { Desenvolvimento de } \\
\text { vizinhança }(\mathrm{ND})\end{array}$ & $\begin{array}{l}\text { Sistema para o desenvolvimento horizontal ou vertical de bairros, condomínios ou } \\
\text { loteamentos com mais de dois prédios residenciais. Abrange princípios de } \\
\text { crescimento inteligente e aspectos urbanísticos em favor do crescimento local } \\
\text { sustentável e ambientalmente responsável. }\end{array}$ \\
\hline Casas & $\begin{array}{l}\text { Orienta o projeto e a construção de residências unifamiliares e multifamiliares de até } \\
50 \text { unidades habitacionais a fim de promover a difusão de moradias verdes de alto } \\
\text { desempenho. É o único ainda não aplicável no Brasil. }\end{array}$ \\
\hline
\end{tabular}

Fonte: <www.bigprojectbrasil.com.br>. Disponível em 21 nov. 2014

Segundo Lannoy (2013), para a elaboração da Tabela 3.4, seguindo a mesma lógica da certificação BREEAM, foi adotado o LEED GBC Brasil Casas. Esta é uma ferramenta bem completa adaptada para o Brasil do LEED for Homes. 
Tabela 3.4 - Resumo LEED Referencial Casas.

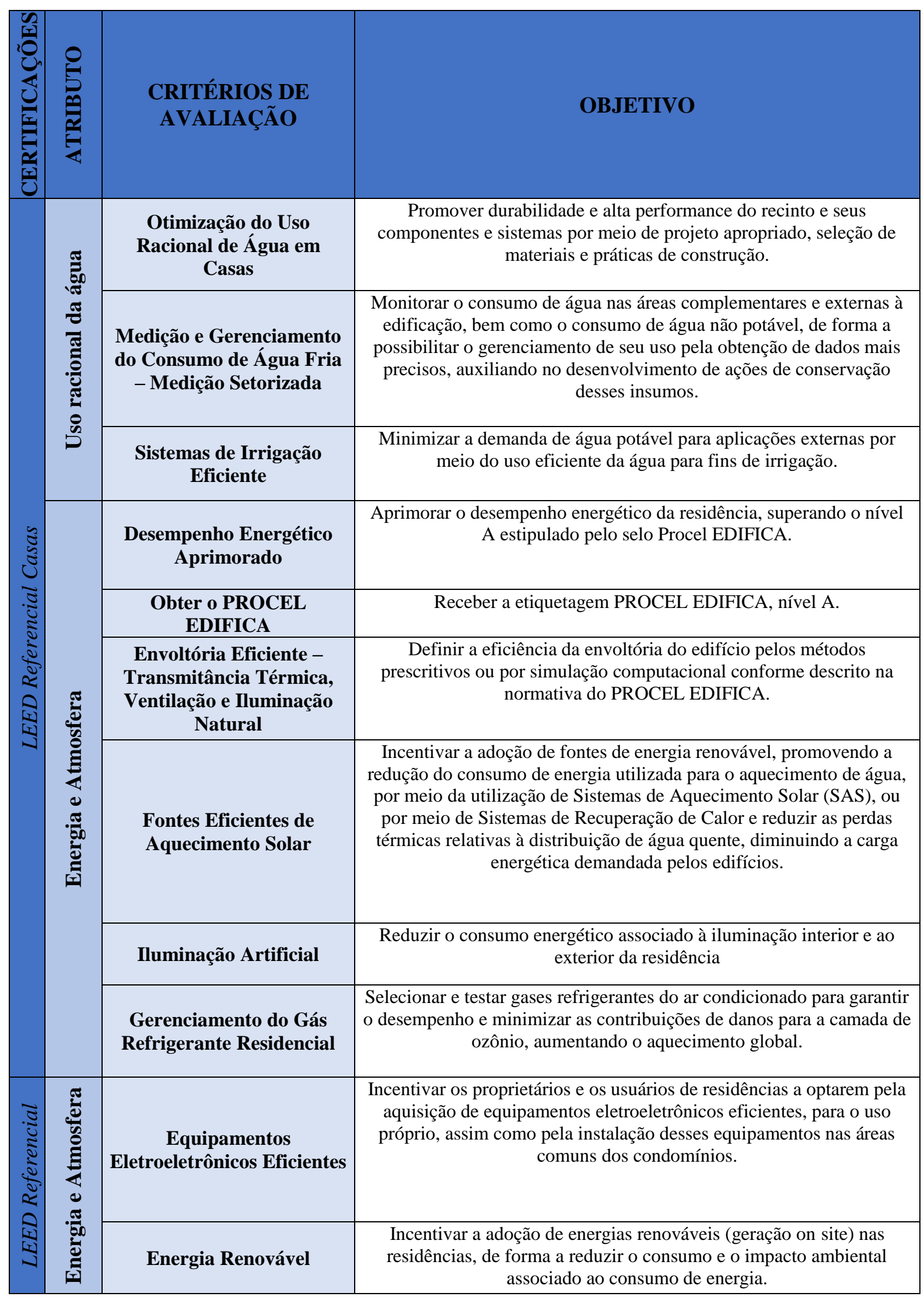




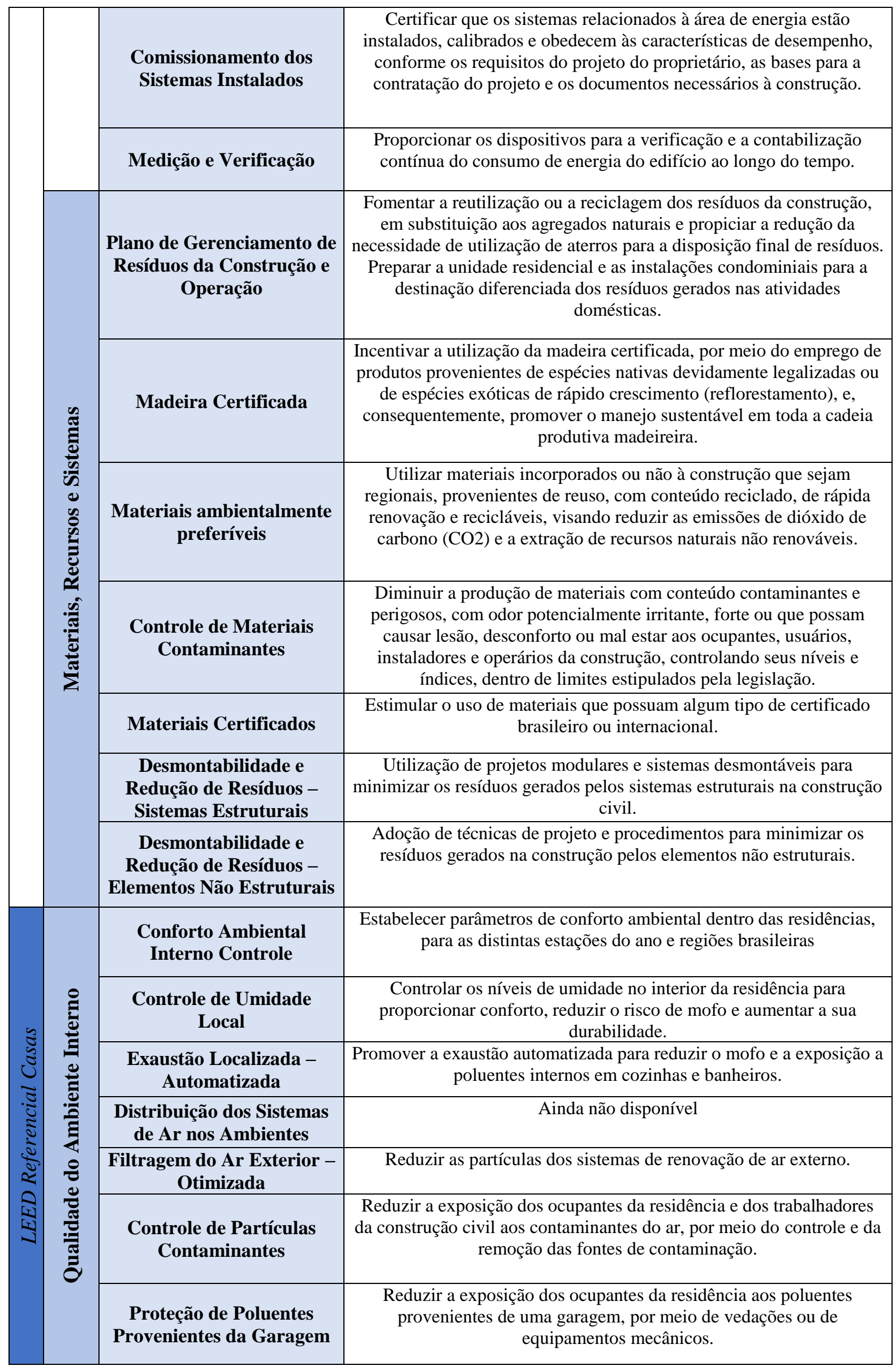




\begin{tabular}{|c|c|c|}
\hline & $\begin{array}{l}\text { Proteção ao Radônio - } \\
\text { Áreas de grande risco }\end{array}$ & $\begin{array}{l}\text { Reduzir a exposição dos ocupantes da residência ao gás radônio e a } \\
\text { outros gases contaminantes provenientes do subsolo. }\end{array}$ \\
\hline & Acústica & $\begin{array}{l}\text { Reduzir a propagação de ruídos externos e o efeito prejudicial que } \\
\text { causam nos ambientes de maior permanência da residência. }\end{array}$ \\
\hline & Acessibilidade Universal & $\begin{array}{l}\text { Projetar a edificação para aumentar a longevidade do seu uso, por meio } \\
\text { da previsão da expansibilidade, acessibilidade ou adaptabilidade para } \\
\text { pessoas da terceira idade e/ou portadores de necessidades especiais. } \\
\text { Ampliar a vida útil da edificação com adequações planejadas, evitando } \\
\text { a geração desnecessária de resíduos. }\end{array}$ \\
\hline 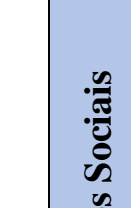 & $\begin{array}{l}\text { Boas Práticas Sociais para } \\
\text { Projeto e Obra }\end{array}$ & $\begin{array}{l}\text { Incentivar o comprometimento empresarial com o bem-estar e inclusão } \\
\text { social dos colaboradores. Minimizar os resíduos gerados em obra, } \\
\text { promover a ampliação da capacidade econômica dos moradores na } \\
\text { área de intervenção e entorno, considerando o período de construção e } \\
\text { operação. }\end{array}$ \\
\hline : & $\begin{array}{l}\text { Boas Práticas Sociais para } \\
\text { Projeto e Obra }\end{array}$ & $\begin{array}{l}\text { Incentivar o comprometimento empresarial com o bem-estar e inclusão } \\
\text { social dos colaboradores. Minimizar os resíduos gerados em obra, } \\
\text { promover a ampliação da capacidade econômica dos moradores na } \\
\text { área de intervenção e entorno, considerando o período de construção e } \\
\text { operação. }\end{array}$ \\
\hline & $\begin{array}{l}\text { Boas Práticas Sociais para } \\
\text { Operação e Manutenção }\end{array}$ & $\begin{array}{c}\text { Estimular o estudo do impacto de implantação da edificação na } \\
\text { comunidade local e produção de material visando manter o uso de boas } \\
\text { práticas durante a vida útil da mesma. Através da educação, } \\
\text { desenvolver e estimular a mudança de comportamento efetiva dos } \\
\text { moradores para uma operação e manutenção mais sustentável do } \\
\text { empreendimento. }\end{array}$ \\
\hline & $\begin{array}{l}\text { Projeto Integrado e } \\
\text { Planejamento }\end{array}$ & $\begin{array}{c}\text { Maximizar oportunidades para integração, custo efetivo da adoção de } \\
\text { projetos verde e estratégias de construção. }\end{array}$ \\
\hline$\frac{e^{e}}{e_{0}^{0}}$ & $\begin{array}{l}\text { Gerenciamento da } \\
\text { Qualidade, visando a } \\
\text { Durabilidade. }\end{array}$ & $\begin{array}{c}\text { Aumentar a durabilidade e o desempenho da envoltória da residência, } \\
\text { bem como de seus componentes e sistemas, por meio de um projeto } \\
\text { adequado, da seleção de materiais e de práticas de construção } \\
\text { convenientes. }\end{array}$ \\
\hline 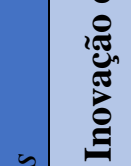 & Manual do Usuário & $\begin{array}{l}\text { Desenvolver um guia que contenha informações sobre o projeto e obra } \\
\text { da residência, assim como informações sobre os equipamentos e } \\
\text { sistemas instalados e como operá-los, para que a mesma mantenha seu } \\
\text { desempenho elevado ao longo de sua vida útil. }\end{array}$ \\
\hline ஜे & Análise de Ciclo de Vida & $\begin{array}{l}\text { Prover a análise e comparação do ciclo de vida de um material } \\
\text { utilizado em obra, incentivando assim, o uso de materiais que causem } \\
\text { menor impacto na sua produção e durante seu ciclo de vida. }\end{array}$ \\
\hline$\frac{1}{2}$ & Inovação e Projeto & $\begin{array}{c}\text { Minimizar o impacto ambiental da residência por meio da } \\
\text { incorporação de técnicas sustentáveis e medidas construtivas que } \\
\text { tenham benefícios tangíveis e demonstráveis, além dos créditos } \\
\text { descritos dentro deste Referencial. }\end{array}$ \\
\hline & $\begin{array}{l}\text { Prioridades Regionais -- } \\
\text { Norte }\end{array}$ & $\begin{array}{l}\text { Incentivar o desenvolvimento e criação de cadeias produtivas } \\
\text { referentes à construção civil, em diferentes regiões do país. }\end{array}$ \\
\hline • & $\begin{array}{l}\text { Prioridades Regionais -- } \\
\text { Nordeste }\end{array}$ & $\begin{array}{l}\text { Incentivar o desenvolvimento e criação de cadeias produtivas } \\
\text { referentes à construção civil, em diferentes regiões do país. }\end{array}$ \\
\hline$\stackrel{n}{0}$ & $\begin{array}{c}\text { Prioridades Regionais -- } \\
\text { Sul }\end{array}$ & $\begin{array}{l}\text { Incentivar o desenvolvimento e criação de cadeias produtivas } \\
\text { referentes à construção civil, em diferentes regiões do país. }\end{array}$ \\
\hline U & $\begin{array}{l}\text { Prioridades Regionais -- } \\
\text { Sudeste }\end{array}$ & $\begin{array}{l}\text { Incentivar o desenvolvimento e criação de cadeias produtivas } \\
\text { referentes à construção civil, em diferentes regiões do país. }\end{array}$ \\
\hline
\end{tabular}




\begin{tabular}{|l|l|c|}
\hline & $\begin{array}{c}\text { Prioridades Regionais - } \\
\text { Centro-Oeste }\end{array}$ & $\begin{array}{c}\text { Incentivar o desenvolvimento e criação de cadeias produtivas } \\
\text { referentes à construção civil, em diferentes regióes do país. }\end{array}$ \\
\hline
\end{tabular}

Fonte: LANNOY, 2013.

A certificação internacional LEED possui 7 dimensões (Figura 3.1) a serem avaliadas nas edificações. Todas as dimensões possuem pré-requisitos que são práticas obrigatórias e créditos, recomendações que quando atendidas, garantem pontos a edificação. O nível da certificação é definido, conforme a quantidade de pontos adquiridos, podendo variar de 40 pontos, nível certificado a 110 pontos, nível platina.

\section{Dimensões Avaliadas}

Sustainable sites (Espaço Sustentável) - Encoraja estratégias que minimizam o impacto no ecossistema durante a implantação da edificação e aborda questões fundamentais de grandes centros urbanos, como redução do uso do carro e das ilhas de calor.

Water efficiency (Eficiência do uso da água) - Promove inovações para o uso racional da água, com foco na redução do consumo de água potável e alternativas de tratamento e reuso dos recursos.

Energy \& atmosphere (Energia e Atmosfera) - Promove eficiência energética nas edificações por meio de estratégias simples e inovadoras, como por exemplo simulações energéticas, medições, comissionamento de sistemas e utilização de equipamentos e sistemas eficientes.

(4) Materials \& resources (Materiais e Recursos) - Encoraja o uso de materiais de baixo impacto ambiental (reciclados, regionais, resíduos gerados dos aterros sanitários.

Indoor environmental quality (Qualidade ambiental interna) - Promove a qualidade ambiental interna do ar, essencial para ambientes com alta permanência de pessoas, com foco na escolha de materiais com baixa emissão de compostos orgânicos voláteis, controlabilidade de sistemas, conforto térmico e priorização de espaços com vista externa e luz natural.

() Innovation in design or innovation in operations (Inovação e Processos) - Incentiva a busca de conhecimento sobre Green Buildings, assim como, a criação de medidas projetuais não descritas nas categorias do LEED. Pontos de desempenho exemplar estão habilitados para esta categoria.

- Regional priority credits (Créditos de Prioridade Regional) - Incentiva os créditos definidos como prioridade regional para cada pais, de acordo com as diferenças ambientais, sociais e econômicas existentes em cada local.. Quatro pontos estão disponíveis para esta categoria.

Figura 3.1 - Critérios de Avaliação - Resumo GBC/LEED.

Fonte: <http://www.gbcbrasil.org.br/sobre-certificado.php>. Disponível em 17 nov. 2014

A Figura 3.2 apresenta o modelo de check list usado para a avaliação do LEED - NC. 


\section{LEED para Novas Construçōes 2009 Registro Projeto Checklist}

Nome do Projteto:

Endereço do Projeto:

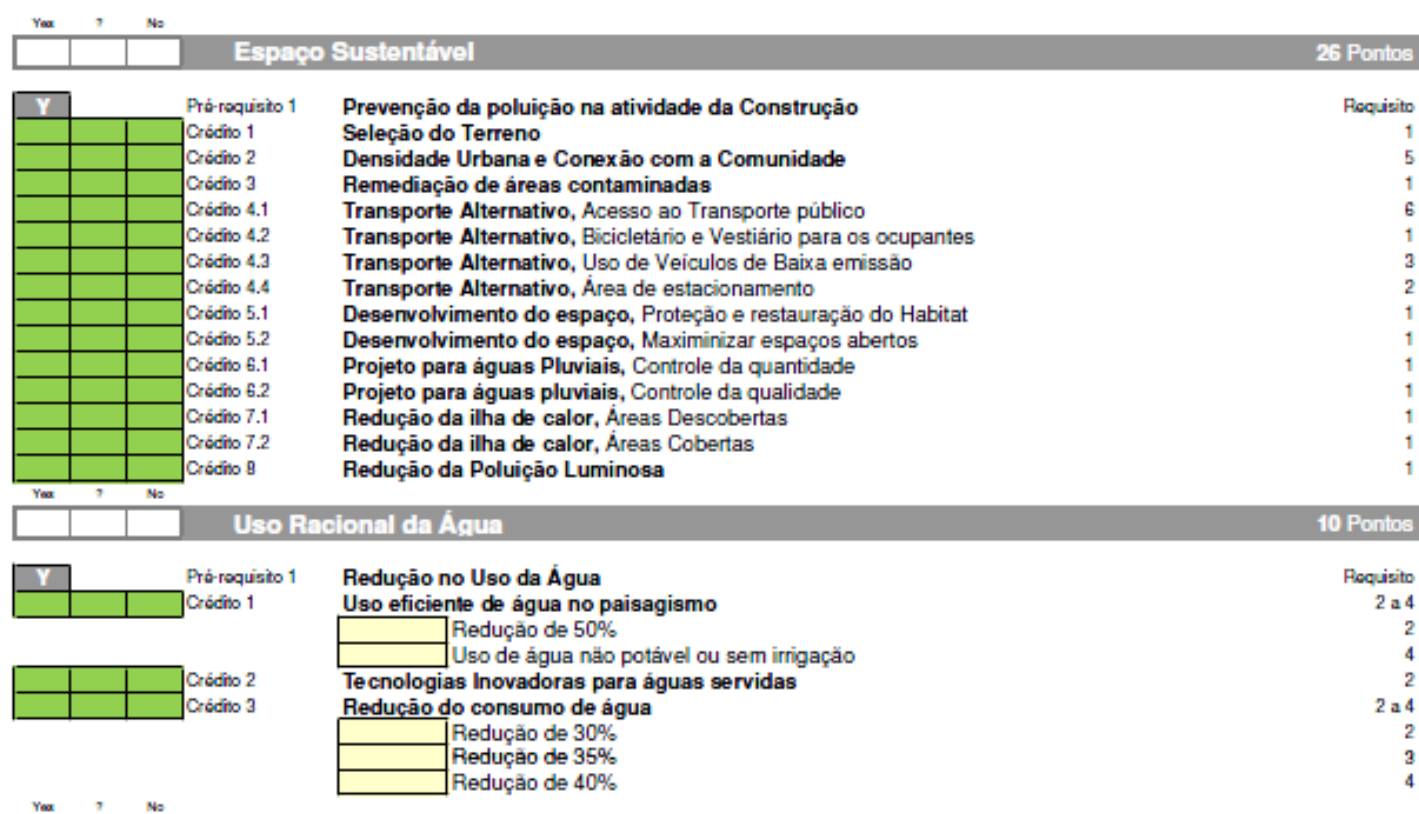

\begin{tabular}{|l|l|l|l|l}
\hline & & Energila e Atmostera & 35 Pontos
\end{tabular}

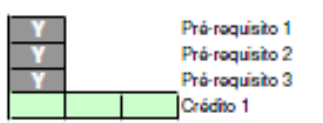

Comissionamento dos sistemas de energia

Requisito

Performance Minima de Energia

Pequisito

Gestāo Fundamental de Gases Refrigerantes, Näo uso de CFC's

Gestäo Fundame ntal de Gases Refriger

$12 \%$ Prédios novos ou $8 \%$ Prédios reformados

$12 \%$ Prédios novos ou $8 \%$ Prédios reformados

$6 \%$ Prédios novos ou $12 \%$ Prédios reformados

$18 \%$ Prédios novos ou $14 \%$ Prédios reformados

$20 \%$ Prédios novos ou $16 \%$ Prédios reformados

$2 \%$ Prédios novos ou $18 \%$ Prédios reformados

$24 \%$ Prédios novos ou $20 \%$ Prédios reformados

$26 \%$ Prédios novos ou $22 \%$ Prédios reformados

$28 \%$ Prédios novos ou $24 \%$ Prédios reformados

$30 \%$ Prédios novos ou $26 \%$ Prédios reformados

$32 \%$ Prédios novos ou $28 \%$ Prédios reformados

$34 \%$ Prédios novos ou $30 \%$ Prédios reformados

$36 \%$ Prédios novos ou $32 \%$ Prédios reformados

$38 \%$ Prédios novos ou $34 \%$ Prédios reformados

$40 \%$ Prédios novos ou $36 \%$ Prédios reformados

$42 \%$ Prédios novos ou $38 \%$ Prédios reformados

$44 \%$ Prédios novos ou $40 \%$ Prédios reformados

$46 \%$ Prédios novos ou $42 \%$ Prédios reformados

$1+1$ Crécíno 2

ocal de energia renovável

$1 \%$ Energia Renovável

\% Energia Renovável

$5 \%$ Energia Renovável

$5 \%$ Energia Renovavel
$7 \%$ Energia Renovável

$9 \%$ Energia Renovável

$1 \%$ Energia Renovável

$13 \%$ Energia Renovável

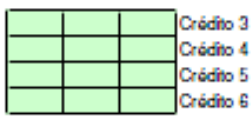

Melhoria no comissionamento

Melhoria na gestão de gases refrigerantes

Mediçōes e Verificaçōes

Energia Verde 


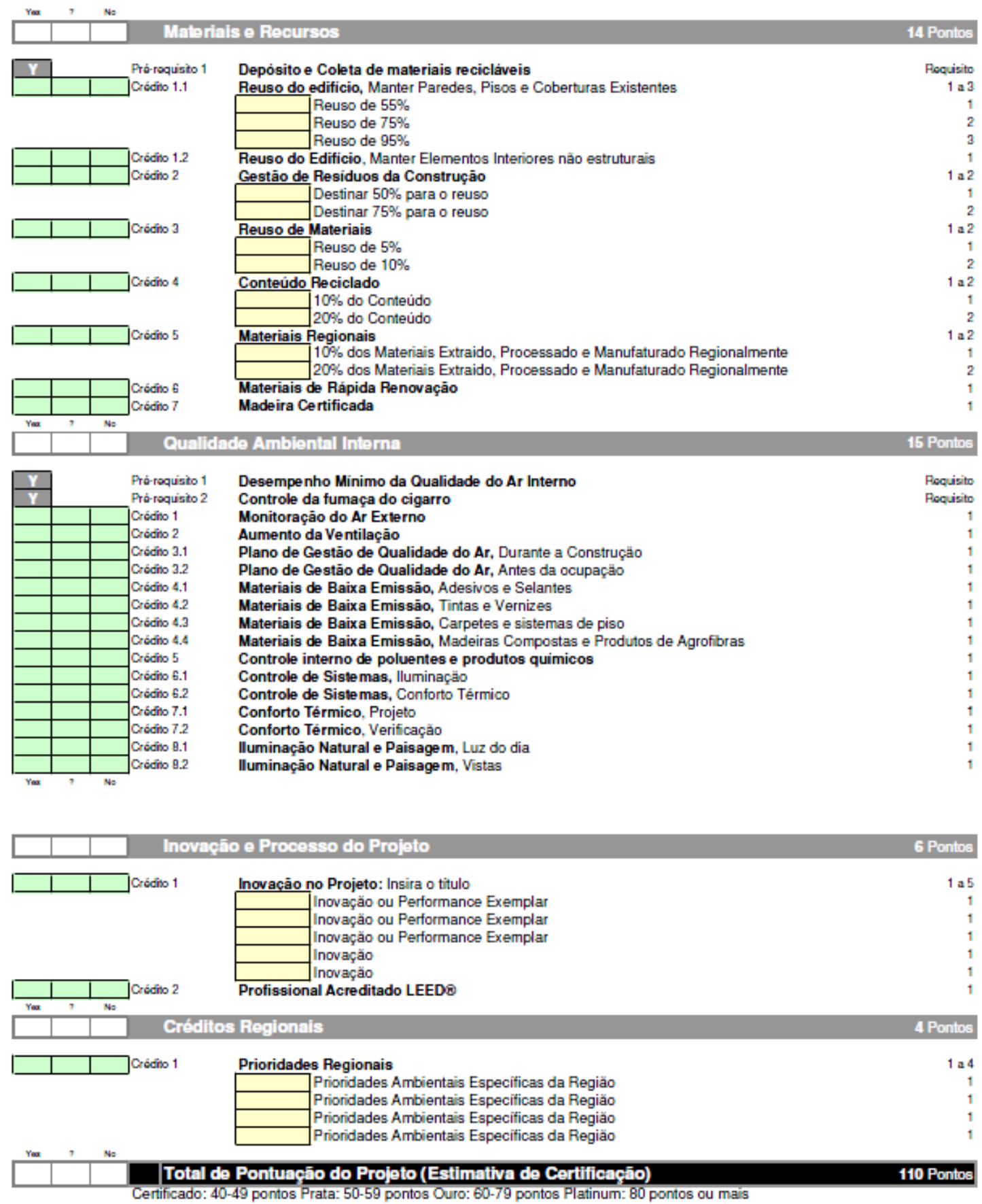

Figura 3.2 - Tabela de Avaliação de Critérios - LEED for homes.

Fonte: 〈http://gbcbrasil.org.br/sistema/certificacao/CheckListLEEDNCv.3Portugues.pdf〉. Acesso em 17 nov. 2014 e <http://www.usgbc.org/leed>. Disponível em 18 nov.2014

\subsection{AQUA}

Já o selo AQUA (Alta Qualidade Ambiental) é o primeiro método brasileiro de certificação ambiental de edifícios a ser lançado para o setor de construção civil. Tendo como fonte de inspiração o selo francês HQE (NF Bâtiments Tertiaires - Démarche) é o primeiro 
selo a levar em conta as especificidades do Brasil para elaborar os 14 critérios que avaliam a gestão ambiental da construção e técnicas arquitetônicas. Os critérios avaliados são:

\section{$\underline{\text { Eco-construção }}$}

- Relação do edifício com o seu entorno;

- Escolha integrada de produtos, sistemas e processos construtivos e

- Canteiro de obras com baixo impacto ambiental.

\section{$\underline{\text { Gestão }}$}

- Da energia;

- Da água;

- Dos resíduos de uso e operação do edifício e

- Manutenção: permanência do desempenho ambiental.

\section{$\underline{\text { Conforto }}$}

- Higrotérmico;

- Acústico;

- Visual e

- Olfativo.

$\underline{\text { Saúde }}$

- Qualidade sanitária dos ambientes;

- Do ar e

- Da água.

Essa certificação é um processo de gestão do projeto visando obter o selo de Alta Qualidade Ambiental de um empreendimento de construção. Foi trazido para o Brasil pela fundação Vanzolini e é mantido pela Escola Politécnica - PRO - USP. 
O método AQUA tem uma configuração diferente da dos outros métodos, por ser um método que estabelece um perfil ao invés de uma pontuação.

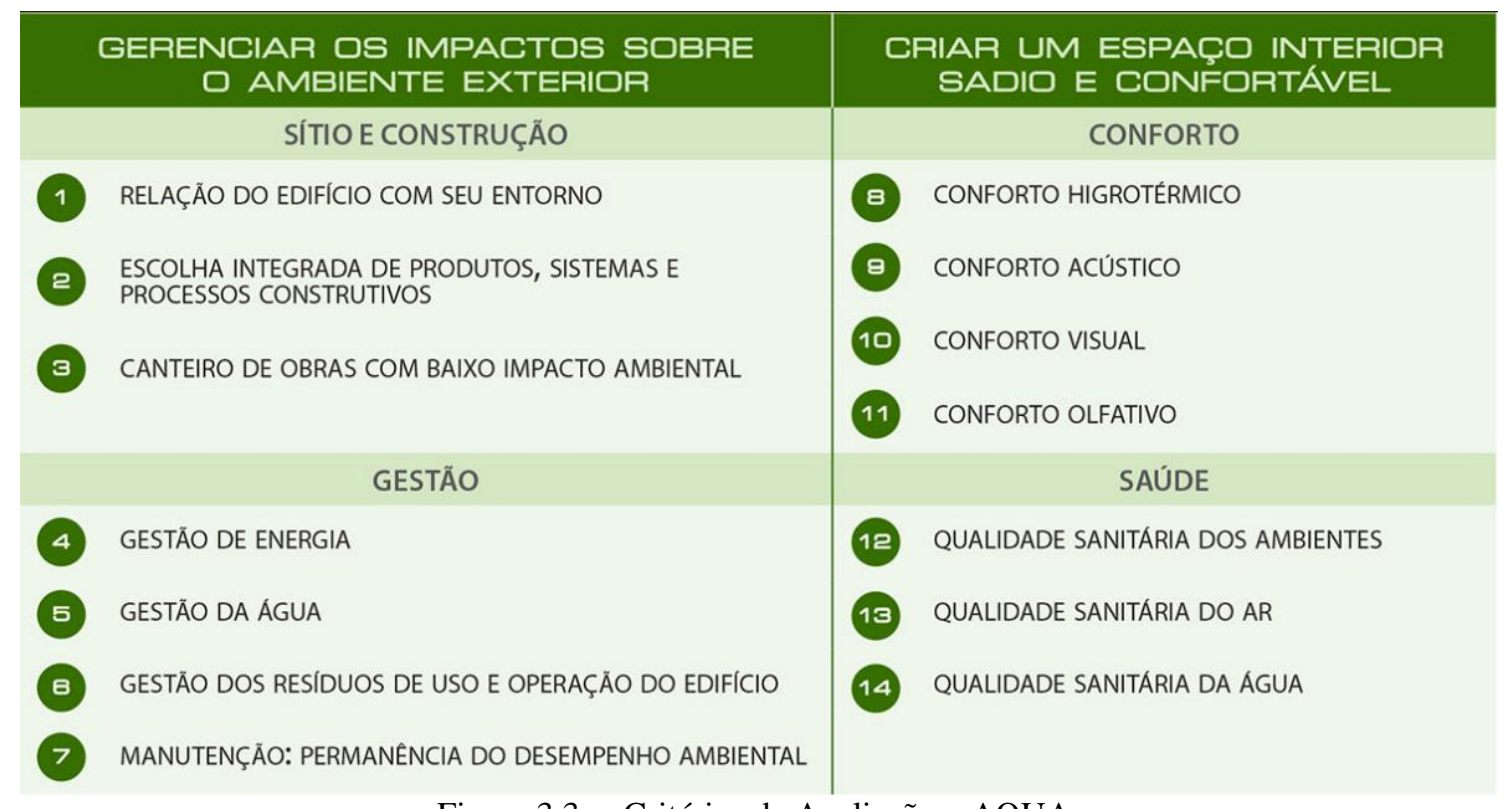

Figura 3.3 - Critérios de Avaliação - AQUA.

Fonte: <http://www.arcoweb.com.br>. Disponível em 21 nov. 2014

Segundo Aulicino (2008), o referencial francês resultou de um amplo processo de busca de um consenso do setor daquele país, envolvendo agentes públicos e privados. No Brasil, o processo AQUA é definido por dois padrões:

O primeiro compreende o SGE - Sistema de Gestão do Empreendimento, que trata da gestão a ser estabelecida pelo empreendedor para assegurar a qualidade ambiental final de sua construção. Permite o planejamento, a operacionalização e o controle de todas as etapas de seu desenvolvimento.

E o segundo corresponde à Qualidade Ambiental do Edifício (QAE), que avalia o desempenho do empreendimento de acordo com suas características técnicas arquitetônicas. (LANNOY, 2013).

O empreendimento é avaliado em pelo menos três fases (construções novas e reformas): pré-projeto (programa de necessidades), projeto (concepção) e execução (para a certificação final). 
A avaliação da Qualidade Ambiental do Edifício é estruturada em 14 categorias e classificadas nos níveis Base, Boas Práticas ou Melhores Práticas, de acordo com o perfil ambiental definindo pelo empreendedor na fase pré-projeto, como pode ser observado no gráfico da Figura 3.4.

\section{Perfil Mínimo de desempenho para certificação}

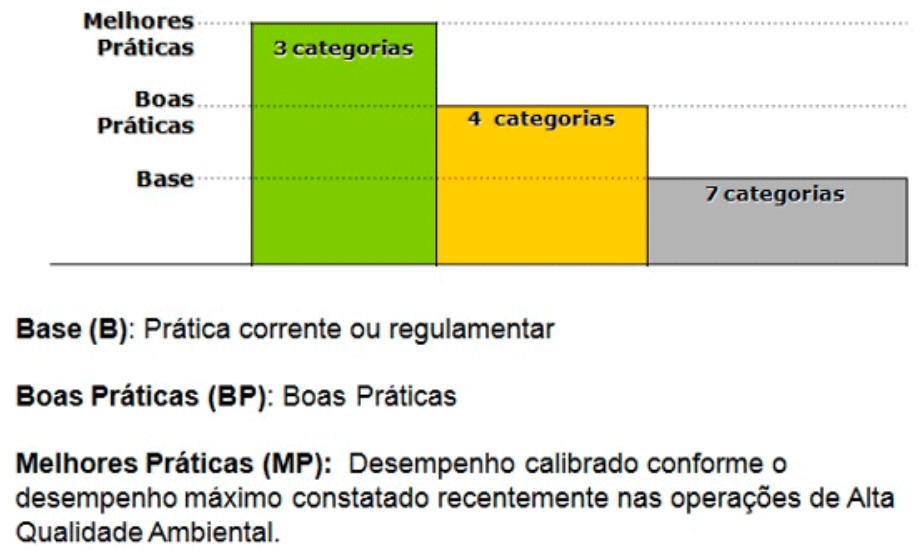

Figura 3.4 - Perfil Mínimo de Desempenho - AQUA.

Fonte: 〈http:www.vanzolini.org.br>. Disponível em 24 nov. 2014

Para que o empreendimento obtenha o certificado AQUA, este deve alcançar um perfil mínimo de desempenho com 3 categorias no nível Melhores Práticas, 4 categorias no nível Boas Práticas e 7 categorias no nível Base.

Visando à similaridade entre os selos BREEAM e LEED e utilizando o relatório técnico Edifícios Habitacionais - versão 2 de 2013, segue a Tabela 3.5, proposta por Lannoy (2013). 
Tabela 3.5 - Resumo AQUA.

\begin{tabular}{|c|c|c|c|}
\hline 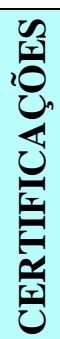 & 号 & $\begin{array}{l}\text { CRITÉRIOS DE } \\
\text { AVALIAÇÃO }\end{array}$ & OBJETIVO \\
\hline \multirow{3}{*}{ 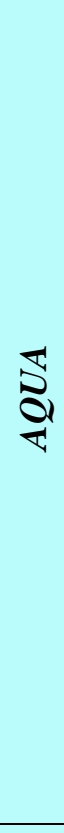 } & \multirow{3}{*}{ 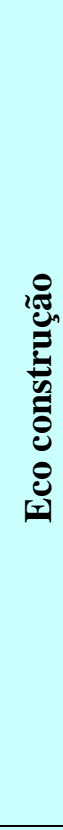 } & $\begin{array}{l}\text { Relação do edifício com } \\
\text { seu entorno }\end{array}$ & $\begin{array}{l}\text { 1.1 Considerações das vantagens e desvantagens do entorno e justificativa } \\
\text { dos objetivos e soluções adotadas para o empreendimento. } 1.2 \\
\text { Ordenamentos da gleba para criar um ambiente exterior agradável. } 1.3 \\
\text { Reduções dos impactos relacionados ao transporte. }\end{array}$ \\
\hline & & $\begin{array}{l}\text { Escolha integrada de } \\
\text { produtos, sistemas e } \\
\text { processos construtivos }\end{array}$ & $\begin{array}{l}\text { 2.1 Escolhas de produtos, sistemas e processos construtivos que garantam a } \\
\text { durabilidade da construção. } 2.2 \text { Escolhas de produtos, sistemas e processos } \\
\text { construtivos a fim de limitar os impactos socioambientais do } \\
\text { empreendimento e de sua construção. } 2.3 \text { Escolhas construtivas adaptadas à } \\
\text { vida útil desejada da construção. } 2.4 \text { Escolhas construtivas considerando a } \\
\text { facilidade de conservação da construção. } 2.5 \text { Revestimentos de piso } \\
\text { (condomínios verticais). } 2.6 \text { Revestimentos de piso (casas). } 2.7 \text { Escolhas dos } \\
\text { fabricantes de produtos que não pratiquem a informalidade na cadeia } \\
\text { produtiva. } 2.8 \text { Flexibilidades da unidade habitacional após a entrega. } 2.9 \\
\text { Acessibilidade e adaptabilidade da unidade habitacional ao envelhecimento. } \\
\text { 2.10 Organização e planejamento da cozinha. }\end{array}$ \\
\hline & & $\begin{array}{l}\text { A participação dos } \\
\text { interessados }\end{array}$ & $\begin{array}{l}\text { 3.1 Disposições contratuais para a obtenção de um canteiro de obras com } \\
\text { baixo impacto ambiental. 3.2 Limitações dos incômodos. 3.3 Limitações dos } \\
\text { riscos sanitários e de poluiçãa podendo afetar o terreno, os trabalhadores e a } \\
\text { vizinhança. } 3.4 \text { Gestões dos resíduos do canteiro de obras. } 3.5 \text { Controle dos } \\
\text { recursos água e energia. } 3.6 \text { Balanços do canteiro de obras. }\end{array}$ \\
\hline \multirow{4}{*}{ 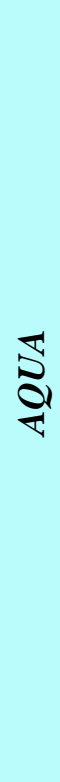 } & \multirow{4}{*}{ 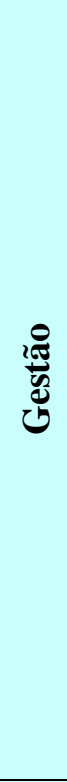 } & Gestão da energia & $\begin{array}{l}\text { 4.1 Reduções do consumo de energia por meio da concepção arquitetônica. } \\
4.2 \text { Usos de energias renováveis locais. } 4.3 \text { Reduções do consumo de energia } \\
\text { para os sistemas de condicionamento de ar, ventilação e exaustão. } 4.4 \\
\text { Reduções do consumo de energia para os sistemas de iluminação. } 4.5 \\
\text { Reduções do consumo de energia para os demais equipamentos. } 4.6 \\
\text { Controles da eficiência energética. } 4.7 \text { Desempenhos do sistema para } \\
\text { produção de água quente. }\end{array}$ \\
\hline & & Gestão da água & $\begin{array}{l}\text { 5.1 Reduções do consumo de água potável. } 5.2 \text { Gestões de águas pluviais. } \\
\text { 5.3 Dimensionamentos do sistema de aquecimento de água. }\end{array}$ \\
\hline & & $\begin{array}{l}\text { Gestão dos resíduos de } \\
\text { uso e operação do } \\
\text { edifício }\end{array}$ & $\begin{array}{l}\text { 6.1 Identificar e classificar a produção de resíduos de uso e operação com a } \\
\text { finalidade de valorização. } 6.2 \text { Adequações entre a coleta interna e a coleta } \\
\text { externa. } 6.3 \text { Controles da triagem dos resíduos. } 6.4 \text { Otimização do sistema de } \\
\text { coleta interna considerando os locais de produção, armazenamento, coleta e } \\
\text { retirada. }\end{array}$ \\
\hline & & Gestão da Manutenção & $\begin{array}{l}\text { 7.1 Facilidades de acesso para a execução da manutenção e simplicidade das } \\
\text { operações. } 7.2 \text { Equipamentos para a permanência do desempenho na fase de } \\
\text { uso. } 7.3 \text { Informações destinadas aos futuros ocupantes e gestores. }\end{array}$ \\
\hline \multirow{2}{*}{ 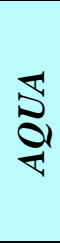 } & \multirow{2}{*}{ 递 } & Conforto higrotérmico & $\begin{array}{l}\text { 8.1 Implementação de medidas arquitetônicas para otimização do conforto } \\
\text { higrotérmico de verão e inverno. } 8.2 \text { Conforto higrotérmico de verão. } 8.3 \\
\text { Conforto higrotérmico de inverno. }\end{array}$ \\
\hline & & Conforto acústico & $\begin{array}{l}\text { 9.1 Conforto acústico entre a unidade habitacional e os outros locais de uma } \\
\text { mesma edificação. } 9.2 \text { Conforto acústico entre os cômodos principais e o } \\
\text { exterior de uma construção. }\end{array}$ \\
\hline
\end{tabular}




\begin{tabular}{|c|c|l|}
\hline \multirow{2}{*}{} & Conforto visual & $\begin{array}{l}\text { 10.1 Aproveitar da melhor maneira os benefícios da iluminação natural. 10.2 } \\
\text { Dispor de uma iluminação artificial confortável. 10.3 Dispor de uma } \\
\text { iluminação artificial das zonas exteriores (entrada, vias internas, acesso ao } \\
\text { estacionamento, ...) confortável e segura. }\end{array}$ \\
\cline { 2 - 4 } & Conforto olfativo & 11.1 Ventilação eficiente. 11.2 Controle das fontes de odores desagradáveis. \\
\hline \multirow{2}{*}{$\begin{array}{c}\text { Qualidade sanitária dos } \\
\text { ambientes }\end{array}$} & $\begin{array}{c}\text { Qualidade sanitária do } \\
\text { ar }\end{array}$ & $\begin{array}{l}12.1 \text { Criar boas condições de higiene nos ambientes. 12.2 Otimizar as } \\
\text { condições sanitárias das áreas de limpeza. 12.3 Controle de exposição } \\
\text { eletromagnética. }\end{array}$ \\
\cline { 2 - 3 } & $\begin{array}{c}13.1 \text { Ventilação eficiente. 13.2 Controle das fontes de poluição internas. 13.3 } \\
\text { Controle das fontes de poluição externas. }\end{array}$ \\
\cline { 2 - 4 } & Qualidade sanitária da & $\begin{array}{l}\text { 14.1 Assegurar a manutenção da qualidade da água destinada ao consumo } \\
\text { humano nas redes internas do edifício. 14.2 Risco de queimadura e e } \\
\text { legionelose. }\end{array}$ \\
\hline
\end{tabular}

Fonte: LANNOY, 2013.

\subsection{Casa Azul Caixa}

O selo da Casa Azul CAIXA boas práticas para habitação mais sustentável é o primeiro sistema ofertado no Brasil, de classificação da sustentabilidade de projetos habitacionais, sendo desenvolvido para a realidade da construção habitacional brasileira. Tem como proposta reconhecer os projetos habitacionais que demostram suas contribuições para a redução dos impactos ambientais e, segundo o Guia Selo Casa Azul, incentivar o uso racional dos recursos naturais na construção de empreendimentos habitacionais, reduzir o custo de manutenção dos edifícios e as despesas mensais de seus usuários, bem como promover a conscientização de empreendedores e moradores sobre as vantagens das construções sustentáveis. Sua metodologia foi desenvolvida por técnicos da CAIXA e por um grupo multidisciplinar de professores da Escola Politécnica da Universidade de São Paulo, Universidade Federal de Santa Catarina e Universidade Estadual de Campinas.

O Selo Casa Azul é avaliado em três níveis: ouro, prata e bronze (Figura 3.5).

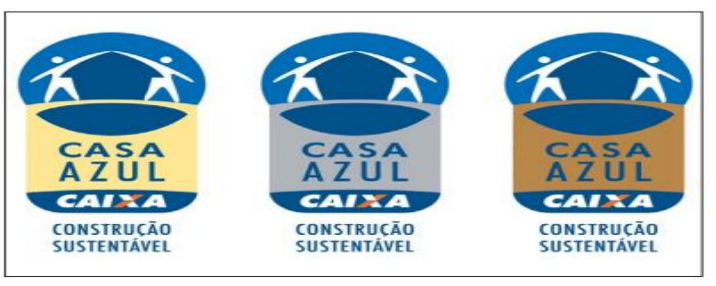

\begin{tabular}{|c|c|}
\hline Gradação & Atendimento mínimo \\
\hline BRONZE & Critérios obrigatórios \\
\hline PRATA & $\begin{array}{c}\text { Critérios obrigatórios e mais } \\
6 \text { critérios de livre escolha }\end{array}$ \\
\hline OURO & $\begin{array}{c}\text { Critérios obrigatórios e mais } \\
12 \text { critérios de livre escolha }\end{array}$ \\
\hline
\end{tabular}

Figura 3.5 - Logomarca e níveis de graduação dos Selos Casa Azul: níveis ouro, prata e bronze. Fonte: <http://downloads.caixa.gov.br/_arquivos/desenvolvimento_urbano/gestao_ambiental/SELO_CA SA_AZUL_CAIXA_versaoweb.pdf>. Disponível em 01 dez. 2014 
Na avaliação, serão considerados 6 categorias subdivididas em 53 critérios. Segundo o Guia Selo Casa Azul, para receber o Selo nível bronze, é necessário preencher os 19 critérios obrigatórios. Para o nível prata, é preciso atender aos itens obrigatórios mais 6 opcionais e, para o nível ouro, os 19 obrigatórios e mais 12 opcionais. As seis categorias são: qualidade urbana, projeto e conforto, eficiência energética, conservação de recursos materiais, gestão da água, e práticas sociais, como pode ser observado no resumo da Tabela 3.6.

Tabela 3.6 - Resumo Selo Casa Azul - Caixa.

\begin{tabular}{|c|c|c|c|}
\hline 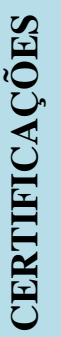 & 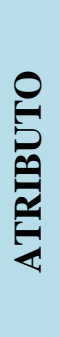 & $\begin{array}{l}\text { CRITÉRIOS DE } \\
\text { AVALIAÇÃO }\end{array}$ & OBJETIVO \\
\hline \multirow{11}{*}{ 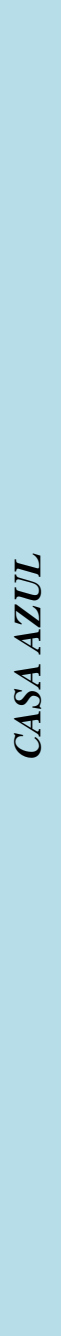 } & \multirow{5}{*}{ 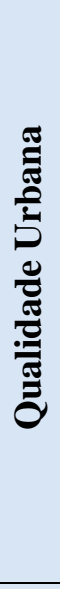 } & $\begin{array}{l}\text { Qualidade do Entorno - } \\
\text { Infraestrutura }\end{array}$ & $\begin{array}{l}\text { Proporcionar aos moradores qualidade de vida, considerando a existência } \\
\text { de infraestrutura, serviços, equipamentos comunitários e comércio } \\
\text { disponíveis no entorno do empreendimento. }\end{array}$ \\
\hline & & $\begin{array}{l}\text { Qualidade do Entorno - } \\
\text { Impactos }\end{array}$ & $\begin{array}{l}\text { Buscar o bem estar, a segurança e a saúde dos moradores, considerando o } \\
\text { impacto do entorno em relação ao empreendimento em análise. }\end{array}$ \\
\hline & & Melhorias no Entorno & $\begin{array}{l}\text { Incentivar ações para melhorias estéticas, funcionais, paisagísticas e de } \\
\text { acessibilidade no entorno do empreendimento. }\end{array}$ \\
\hline & & $\begin{array}{l}\text { Recuperação de Áreas } \\
\text { Degradadas }\end{array}$ & Incentivar a recuperação de áreas social e/ou ambientalmente degradadas. \\
\hline & & Reabilitação de Imóveis & $\begin{array}{l}\text { Incentivar a reabilitação de edificações e a ocupação de vazios urbanos, } \\
\text { especialmente nas áreas centrais, de modo a devolver ao meio ambiente, } \\
\text { ao ciclo econômico e à dinâmica urbana uma edificação ou área antes em } \\
\text { desuso, impossibilitada de uso ou subutilizada. }\end{array}$ \\
\hline & \multirow{6}{*}{ 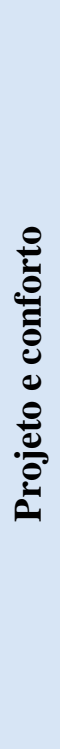 } & Paisagismo & $\begin{array}{l}\text { Auxiliar no conforto térmico e visual do empreendimento, mediante } \\
\text { regulação de umidade, sombreamento vegetal e uso de elementos } \\
\text { paisagísticos. }\end{array}$ \\
\hline & & Flexibilidade de Projeto & $\begin{array}{l}\text { Permitir o aumento da versatilidade da edificação, por meio de } \\
\text { modificação de projeto e futuras ampliações, adaptando-se às necessidades } \\
\text { do usuário. }\end{array}$ \\
\hline & & Relação com a Vizinhança & Minimizar os impactos negativos do empreendimento sobre a vizinhança. \\
\hline & & $\begin{array}{l}\text { Solução Alternativa de } \\
\text { Transporte }\end{array}$ & $\begin{array}{l}\text { Incentivar o uso, pelos condôminos, de meio de transporte menos } \\
\text { poluentes, visando a reduzir o impacto produzido pelo uso de veículos } \\
\text { automotores. }\end{array}$ \\
\hline & & Local para Coleta Seletiva & $\begin{array}{l}\text { Possibilitar a realização da separação dos recicláveis (resíduos sólidos } \\
\text { domiciliares - RSD) no empreendimento. }\end{array}$ \\
\hline & & $\begin{array}{l}\text { Equipamentos de Lazer, } \\
\text { Sociais e Esportivos }\end{array}$ & $\begin{array}{l}\text { Incentivar práticas saudáveis de convivência e entretenimento dos } \\
\text { moradores, mediante à implantação de equipamentos de lazer, sociais e } \\
\text { esportivos nos empreendimentos. }\end{array}$ \\
\hline
\end{tabular}




\begin{tabular}{|c|c|c|c|}
\hline \multirow{15}{*}{ 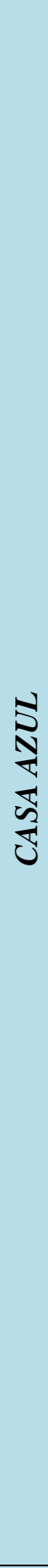 } & \multirow{5}{*}{ 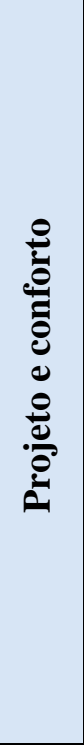 } & $\begin{array}{l}\text { Desempenho Térmico - } \\
\text { Vedações }\end{array}$ & $\begin{array}{l}\text { Proporcionar ao usuário melhores condições de conforto térmico, } \\
\text { conforme as diretrizes gerais para projeto correspondentes à zona } \\
\text { bioclimática do local do empreendimento, controlando-se a ventilação e } \\
\text { a radiação solar que ingressa pelas aberturas ou que é absorvida pelas } \\
\text { vedações externas da edificação. }\end{array}$ \\
\hline & & $\begin{array}{l}\text { Desempenho Térmico - } \\
\text { Orientação ao Sol e } \\
\text { Ventos }\end{array}$ & $\begin{array}{l}\text { Proporcionar ao usuário condições de conforto térmico mediante } \\
\text { estratégias de projeto, conforme à zona bioclimática do local do } \\
\text { empreendimento, considerando-se a implantação da edificação em } \\
\text { relação à orientação solar, aos ventos dominantes e à interferência de } \\
\text { elementos físicos do entorno, construídos ou naturais. }\end{array}$ \\
\hline & & $\begin{array}{l}\text { Iluminação Natural de } \\
\text { Áreas Comuns }\end{array}$ & $\begin{array}{l}\text { Melhorar a salubridade do ambiente, além de reduzir o consumo de } \\
\text { energia mediante iluminação natural nas áreas comuns, escadas e } \\
\text { corredores dos edifícios. }\end{array}$ \\
\hline & & $\begin{array}{l}\text { Ventilação e Iluminação } \\
\text { Natural de Banheiros }\end{array}$ & $\begin{array}{l}\text { Melhorar a salubridade do ambiente, além de reduzir o consumo de } \\
\text { energia nas áreas dos banheiros. }\end{array}$ \\
\hline & & $\begin{array}{l}\text { Adequação às condições } \\
\text { Físicas do Terreno }\end{array}$ & $\begin{array}{l}\text { Minimizar o impacto causado pela implantação do empreendimento na } \\
\text { topografia e em relação aos elementos naturais do terreno. }\end{array}$ \\
\hline & \multirow{7}{*}{ 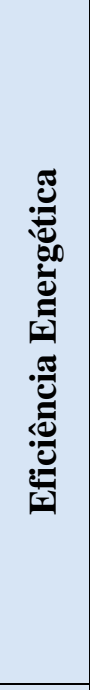 } & $\begin{array}{c}\text { Lâmpadas de Baixo } \\
\text { Consumo - Áreas } \\
\text { Privativas } \\
\end{array}$ & $\begin{array}{l}\text { Reduzir o consumo de energia elétrica mediante o uso de lâmpadas } \\
\text { eficientes. }\end{array}$ \\
\hline & & $\begin{array}{c}\text { Dispositivos } \\
\text { Economizadores - Áreas } \\
\text { Comuns } \\
\end{array}$ & $\begin{array}{l}\text { Reduzir o consumo de energia elétrica mediante a utilização de } \\
\text { dispositivos economizadores e/ou lâmpadas eficientes nas áreas comuns. }\end{array}$ \\
\hline & & $\begin{array}{l}\text { Sistema de Aquecimento } \\
\text { Solar }\end{array}$ & $\begin{array}{l}\text { Reduzir o consumo de energia elétrica ou de gás para o aquecimento de } \\
\text { água. }\end{array}$ \\
\hline & & $\begin{array}{l}\text { Sistemas de Aquecimento } \\
\text { à Gás }\end{array}$ & Reduzir o consumo de gás com o equipamento. \\
\hline & & $\begin{array}{c}\text { Medição Individualizada } \\
\text { - Gás }\end{array}$ & $\begin{array}{l}\text { Proporcionar aos moradores o gerenciamento do consumo de gás da sua } \\
\text { unidade habitacional, conscientizando-os sobre seus gastos e } \\
\text { possibilitando a redução do consumo. }\end{array}$ \\
\hline & & Elevadores Eficientes & $\begin{array}{l}\text { Reduzir o consumo de energia elétrica com a utilização de sistemas } \\
\text { operacionais eficientes na edificação. }\end{array}$ \\
\hline & & $\begin{array}{l}\text { Eletrodomésticos } \\
\text { Eficientes }\end{array}$ & Reduzir o consumo de energia com eletrodomésticos. \\
\hline & \multirow{3}{*}{ 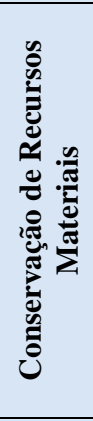 } & $\begin{array}{l}\text { Coordenação Modular } \\
\quad \text { (modulação) }\end{array}$ & $\begin{array}{l}\text { Reduzir as perdas de materiais pela necessidade de cortes, ajustes de } \\
\text { componentes e uso de material de enchimento; aumentar a produtividade } \\
\text { da construção civil e reduzir o volume de RCD. }\end{array}$ \\
\hline & & $\begin{array}{l}\text { Qualidade de Materiais e } \\
\text { Componentes }\end{array}$ & $\begin{array}{l}\text { Evitar o uso de produtos de baixa qualidade, reduzindo o consumo de } \\
\text { recursos naturais utilizados na correção e os custos de correção de } \\
\text { defeitos, além de melhorar as condições de competitividade dos } \\
\text { fabricantes que operam em conformidade com a normalização. }\end{array}$ \\
\hline & & $\begin{array}{c}\text { Componentes } \\
\text { Industrializados ou Pré- } \\
\text { fabricados }\end{array}$ & $\begin{array}{l}\text { Reduzir as perdas de materiais e a geração de resíduos, colaborando para } \\
\text { a redução do consumo de recursos naturais pelo emprego de } \\
\text { componentes industrializados. }\end{array}$ \\
\hline \multirow{3}{*}{ 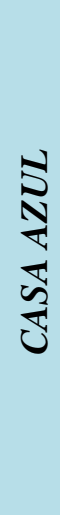 } & \multirow{3}{*}{ 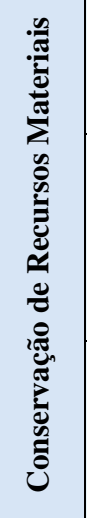 } & $\begin{array}{l}\text { Formas e Escoras } \\
\text { Reutilizáveis }\end{array}$ & $\begin{array}{l}\text { Reduzir o emprego de madeira em aplicações de baixa durabilidade, que } \\
\text { constituem desperdício, e incentivar o uso de materiais reutilizáveis. }\end{array}$ \\
\hline & & $\begin{array}{l}\text { Gestão de Resíduos de } \\
\text { Construção e Demolição } \\
\text { (RCD) }\end{array}$ & $\begin{array}{l}\text { Reduzir a quantidade de resíduos de construção e demolição e seus } \\
\text { impactos no meio ambiente urbano e nas finanças municipais por meio } \\
\text { da promoção ao respeito das diretrizes estabelecidas nas Resoluções n. } \\
307 \text { e n. } 348 \text { do Conama (BRASIL, } 2002 \text { e 2004). }\end{array}$ \\
\hline & & $\begin{array}{c}\text { Concreto com Dosagem } \\
\text { Otimizada }\end{array}$ & $\begin{array}{l}\text { Otimizar o uso do cimento na produção de concretos estruturais, por } \\
\text { meio de processos de dosagem e produção controlados e de baixa } \\
\text { variabilidade, sem redução da segurança estrutural, preservando recursos } \\
\text { naturais escassos e reduzindo as emissões de } \mathrm{CO} 2 \text {. }\end{array}$ \\
\hline
\end{tabular}




\begin{tabular}{|c|c|c|c|}
\hline & & $\begin{array}{l}\text { Cimento de Alto-Forno } \\
\text { (CP III) e Pozolânico (CP } \\
\text { IV) }\end{array}$ & $\begin{array}{l}\text { Redução das emissões de } \mathrm{CO} 2 \text { associadas à produção do clínquer de } \\
\text { cimento Portland e redução do uso de recursos naturais não renováveis } \\
\text { escassos (calcário) através de sua substituição por resíduos (escórias e } \\
\text { cinzas volantes) ou materiais abundantes (pozolana produzida com argila } \\
\text { calcinada). }\end{array}$ \\
\hline & & Pavimentação com RCD & $\begin{array}{l}\text { Reduzir a pressão sobre recursos naturais não renováveis por meio do } \\
\text { uso de materiais reciclados e pela promoção de mercado de agregados } \\
\text { reciclados. }\end{array}$ \\
\hline & & $\begin{array}{l}\text { Madeira Plantada ou } \\
\text { Certificada }\end{array}$ & $\begin{array}{l}\text { Reduzir a demanda por madeiras nativas de florestas não manejadas pela } \\
\text { promoção do uso de madeira de espécies exóticas plantadas ou madeira } \\
\text { nativa certificada. }\end{array}$ \\
\hline & & $\begin{array}{c}\text { Facilidade de } \\
\text { Manutenção da Fachada }\end{array}$ & $\begin{array}{l}\text { Reduzir as atividades de manutenção e os impactos ambientais } \\
\text { associados à pintura frequente da fachada, que apresentam custos } \\
\text { elevados, particularmente para moradores de habitação de interesse } \\
\text { social. }\end{array}$ \\
\hline & & Informalidade Zero & $\begin{array}{l}\text { A construção sustentável se inicia pelo processo de seleção de } \\
\text { fornecedores. Somente empresas que operam exclusivamente de maneira } \\
\text { formal podem produzir e fornecer materiais de forma compatível com o } \\
\text { desenvolvimento sustentável. }\end{array}$ \\
\hline & \multirow{6}{*}{ 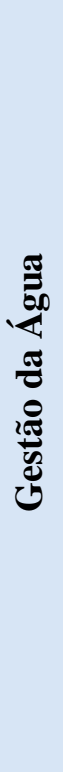 } & $\begin{array}{c}\text { Medição Individualizada } \\
\text { - Água }\end{array}$ & $\begin{array}{l}\text { Possibilitar aos usuários o gerenciamento do consumo de água de sua } \\
\text { unidade habitacional, de forma a facilitar a redução de consumo. }\end{array}$ \\
\hline & & $\begin{array}{c}\text { Dispositivos } \\
\text { Economizadores - } \\
\text { Sistema de Descarga }\end{array}$ & Proporcionar a redução do consumo de água. \\
\hline & & $\begin{array}{c}\text { Dispositivos } \\
\text { Economizadores - } \\
\text { Arejadores } \\
\end{array}$ & $\begin{array}{l}\text { Proporcionar a redução do consumo de água e maior conforto ao usuário, } \\
\text { propiciado pela melhor dispersão do jato em torneiras. }\end{array}$ \\
\hline & & $\begin{array}{c}\text { Dispositivos } \\
\text { Economizadores - } \\
\text { Registro Regulador de } \\
\text { Vazão } \\
\end{array}$ & $\begin{array}{l}\text { Proporcionar a redução do consumo de água nos demais pontos de } \\
\text { utilização. }\end{array}$ \\
\hline & & $\begin{array}{l}\text { Aproveitamento de } \\
\text { Águas Pluviais }\end{array}$ & $\begin{array}{l}\text { Reduzir o consumo de água potável para determinados usos, tais como } \\
\text { em bacia sanitária, irrigação de áreas verdes, lavagem de pisos, lavagem } \\
\text { de veículos e espelhos d'água. }\end{array}$ \\
\hline & & $\begin{array}{l}\text { Retenção de Águas } \\
\text { Pluviais }\end{array}$ & $\begin{array}{l}\text { Permitir o escoamento das águas pluviais de modo controlado, com } \\
\text { vistas a prevenir o risco de inundações em regiões com alta } \\
\text { impermeabilização do solo e desonerar as redes públicas de drenagem. }\end{array}$ \\
\hline \multirow{6}{*}{ 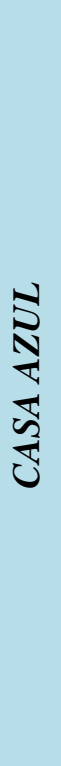 } & \multirow{2}{*}{ 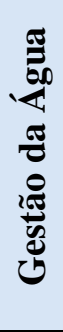 } & $\begin{array}{l}\text { Infiltração de Águas } \\
\text { Pluviais }\end{array}$ & $\begin{array}{l}\text { Permitir o escoamento das águas pluviais de modo controlado ou } \\
\text { favorecer a sua infiltração no solo, com vistas a prevenir o risco de } \\
\text { inundações, reduzir a poluição difusa, amenizar a solicitação das redes } \\
\text { públicas de drenagem e propiciar a recarga do lençol freático. }\end{array}$ \\
\hline & & Áreas Permeáveis & $\begin{array}{l}\text { Manter, tanto quanto possível, o ciclo da água com a recarga do lençol } \\
\text { freático, prevenir o risco de inundação em áreas com alta } \\
\text { impermeabilização do solo e amenizar a solicitação das redes públicas de } \\
\text { drenagem urbana. }\end{array}$ \\
\hline & \multirow{4}{*}{ 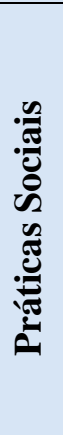 } & $\begin{array}{l}\text { Educação para a Gestão } \\
\text { de RCD }\end{array}$ & $\begin{array}{l}\text { Realizar atividades educativas e de mobilização para os empregados } \\
\text { envolvidos no empreendimento tendo em vista a execução das diretrizes } \\
\text { do plano de gestão de RCD. }\end{array}$ \\
\hline & & $\begin{array}{l}\text { Educação Ambiental dos } \\
\text { Empregados }\end{array}$ & $\begin{array}{l}\text { Prestar informações e orientar os trabalhadores sobre a utilização dos } \\
\text { itens de sustentabilidade do empreendimento, notadamente sobre os } \\
\text { aspectos ambientais. }\end{array}$ \\
\hline & & $\begin{array}{c}\text { Desenvolvimento Pessoal } \\
\text { dos Empregados }\end{array}$ & $\begin{array}{l}\text { Proporcionar atividades educativas aos trabalhadores, visando à melhoria } \\
\text { das suas condições de vida. }\end{array}$ \\
\hline & & $\begin{array}{l}\text { Capacitação Profissional } \\
\text { dos Empregados }\end{array}$ & $\begin{array}{l}\text { Prover os trabalhadores de capacitação profissional, visando à melhoria } \\
\text { de seu desempenho e das suas condições socioeconômicas. }\end{array}$ \\
\hline
\end{tabular}




\begin{tabular}{|c|c|}
\hline $\begin{array}{l}\text { Capacitação Profissional } \\
\text { dos Empregados }\end{array}$ & $\begin{array}{l}\text { Prover os trabalhadores de capacitação profissional, visando à melhoria } \\
\text { de seu desempenho e das suas condições socioeconômicas. }\end{array}$ \\
\hline $\begin{array}{l}\text { Inclusão de } \\
\text { Trabalhadores Locais }\end{array}$ & $\begin{array}{l}\text { Promover a ampliação da capacidade econômicas dos moradores da área } \\
\text { de intervenção e seu entorno ou de futuros moradores do } \\
\text { empreendimento por meio da contratação dessa população, } \\
\text { estabelecendo uma relação positiva dos mesmos com o empreendimento. }\end{array}$ \\
\hline $\begin{array}{l}\text { Participação da } \\
\text { Comunidade na } \\
\text { Elaboração do Projeto }\end{array}$ & $\begin{array}{l}\text { Promover a participação e o envolvimento da população-alvo na } \\
\text { implantação do empreendimento e na consolidação deste como } \\
\text { sustentável, desde sua concepção, como forma de estimular a } \\
\text { permanência dos moradores no imóvel e a valorização da benfeitoria. }\end{array}$ \\
\hline $\begin{array}{l}\text { Orientação aos } \\
\text { Moradores }\end{array}$ & $\begin{array}{l}\text { Prestar informações e orientar os moradores quanto ao uso e à } \\
\text { manutenção adequada do imóvel, considerando-se os aspectos de } \\
\text { sustentabilidade previstos no projeto. }\end{array}$ \\
\hline $\begin{array}{l}\text { Educação Ambiental dos } \\
\text { Moradores }\end{array}$ & $\begin{array}{l}\text { Prestar informações e orientar os moradores sobre as questões ambientais } \\
\text { e os demais eixos que compõem a sustentabilidade. }\end{array}$ \\
\hline $\begin{array}{l}\text { Capacitação para Gestão } \\
\text { do Empreendimento }\end{array}$ & $\begin{array}{l}\text { Fomentar a organização social dos moradores e capacitá-los para a } \\
\text { gestão do empreendimento. }\end{array}$ \\
\hline $\begin{array}{l}\text { Ações para Mitigação de } \\
\text { Riscos Sociais }\end{array}$ & $\begin{array}{l}\text { Propiciar a inclusão social de população em situação de vulnerabilidade } \\
\text { social, bem como desenvolver ações socioeducativas para os demais } \\
\text { moradores da área e do entorno, com vistas a reduzir o impacto do } \\
\text { empreendimento em suas adjacências, e favorecer a resolução de } \\
\text { possíveis conflitos gerados pela construção e inserção de novos } \\
\text { habitantes na comunidade já instalada. }\end{array}$ \\
\hline $\begin{array}{l}\text { Ações para a Geração de } \\
\text { Emprego e Renda }\end{array}$ & Promover o desenvolvimento socioeconômico dos moradores \\
\hline
\end{tabular}

Fonte: LANNOY, 2013.

$\mathrm{Na}$ Tabela 3.7, seguem os itens propostos que são verificados com as respectivas obrigatoriedades. $\mathrm{O}$ atendimento a estes itens em projeto será verificado também no curso do acompanhamento da obra, durante as medições mensais ou em vistorias específicas. 
Tabela 3.7 - Tabela Resumo das Categorias, Critérios e Classificação do Selo Casa Azul - Caixa.

\begin{tabular}{|c|c|c|c|c|}
\hline \multicolumn{5}{|c|}{ TABELA RESUMO - CATEGORIAS, CRITÉRIOS E CLASSIFICAÇÃO } \\
\hline \multicolumn{2}{|r|}{ CATEGORIAS, CRITÉRIOS } & \multicolumn{3}{|c|}{ CLASSIFICAÇÃO } \\
\hline 1. & QUALIDADE URBANA & BRONZE & PRATA & OURO \\
\hline & Qualidade do Entorno - Infraestrutura & obrigatório & \multirow{29}{*}{$\begin{array}{c}\text { critérios } \\
\text { obrigatórios } \\
+6 \text { itens de } \\
\text { livre escolha }\end{array}$} & \multirow{29}{*}{$\begin{array}{c}\text { critérios } \\
\text { obrigatórios } \\
+12 \text { itens de } \\
\text { livre escolha }\end{array}$} \\
\hline 1.2 & Qualidade do Entorno - Impactos & obrigatório & & \\
\hline 1.3 & Melhorias do Entorno & & & \\
\hline 1.4 & Recuperação de Áreas Degradadas & & & \\
\hline 1.5 & Reabilitação de Imóveis & & & \\
\hline 2. & PROJETO E CONFORTO & & & \\
\hline & Paisagismo & obrigatório & & \\
\hline 2.2 & Flexibilidade de Projeto & & & \\
\hline & Relação com a Vizinhança & & & \\
\hline & Solução Alternativa de Transporte & & & \\
\hline 2.5 & Local para Coleta Seletiva & obrigatório & & \\
\hline 2.6 & Equipamentos de Lazer, Sociais e Esportivos & obrigatório & & \\
\hline 2.7 & Desempenho Térmico - Vedações & obrigatório & & \\
\hline & Desempenho Térmico - Orientação ao Sol e Ventos & obrigatório & & \\
\hline 2.9 & Iluminação Natural de Áreas Comuns & & & \\
\hline 2.10 & Ventilação e Iluminação Natural de Banheiros & & & \\
\hline 2.11 & Adequação às Condições Físicas do Terreno & & & \\
\hline \multicolumn{3}{|c|}{ 3. EFICIÊNCIA ENERGÉTICA } & & \\
\hline & Lâmpadas de Baixo Consumo - Áreas Privativas & $\begin{array}{c}\text { obrigatório } \\
\text { p/ HIS - até } \\
3 \text { s.m. }\end{array}$ & & \\
\hline 3.2 & Dispositivos Economizadores - Áreas Comuns & obrigatório & & \\
\hline & Sistema de Aquecimento Solar & & & \\
\hline & Sistema de Aquecimento à Gás & & & \\
\hline 3.5 & Medição Individualizada - Gás & obrigatório & & \\
\hline 3.6 & Elevadores Eficientes & & & \\
\hline & Eletrodomésticos Eficientes & & & \\
\hline 3.8 & Fontes Alternativas de Energia & & & \\
\hline 4. & CONSERVAÇÃO DE RECURSOS MATERIAIS & & & \\
\hline & Coordenação Modular & & & \\
\hline & Qualidade de Materiais e Componentes & obrigatório & & \\
\hline
\end{tabular}




\begin{tabular}{|c|c|c|c|c|}
\hline \multicolumn{5}{|c|}{ TABELA RESUMO - CATEGORIAS, CRITÉRIOS E CLASSIFICAÇÃO } \\
\hline \multicolumn{2}{|r|}{ CATEGORIAS, CRITÉRIOS } & \multicolumn{3}{|c|}{ CLASSIFICAÇÃO } \\
\hline 4. & CONSERVAÇÃO DE RECURSOS MATERIAIS & BRONZE & PRATA & OURO \\
\hline & Componentes Industrializados ou Pré-Fabricados & & \multirow{29}{*}{$\begin{array}{l}\text { critérios } \\
\text { obrigatórios }+6 \\
\text { itens de livre } \\
\text { escolha }\end{array}$} & \multirow{29}{*}{$\begin{array}{c}\text { critérios } \\
\text { obrigatórios } \\
+12 \text { itens de } \\
\text { livre escolha }\end{array}$} \\
\hline 4.4 & Formas e Escoras Reutilizáveis & obrigatório & & \\
\hline 4.5 & Gestão de Resíduos de Construção e Demolição (RCD) & obrigatório & & \\
\hline 4.6 & Concreto em Dosagem Otimizada & & & \\
\hline 4.7 & Cimento de Alto-Forno (CPIII) e Pozolânico (CPIV) & & & \\
\hline 4.8 & Pavimentação com RCD & & & \\
\hline 4.9 & Facilidade de Manutenção da Fachada & & & \\
\hline 4.10 & Madeira Plantada ou Certificada & & & \\
\hline 5. & GESTÃO DA ÁGUA & & & \\
\hline & Medição Individualizada - Água & obrigatório & & \\
\hline 5.2 & Dispositivos Economizadores - Sistema de Descarga & obrigatório & & \\
\hline 5.3 & Dispositivos Economizadores - Arejadores & & & \\
\hline 5.4 & Dispositivos Economizadores - Registro Regulador de Vazão & & & \\
\hline 5.5 & Aproveitamento de Águas Pluviais & & & \\
\hline 5.6 & Retenção de Águas Pluviais & & & \\
\hline 5.7 & Infiltração de Águas Pluviais & & & \\
\hline & Áreas Permeáveis & obrigatório & & \\
\hline \multicolumn{3}{|c|}{ 6. PRÁTICAS SOCIAIS } & & \\
\hline 6.1 & Educação para a Gestão de RCD & obrigatório & & \\
\hline 6.2 & Educação Ambiental dos Empregados & obrigatório & & \\
\hline 6.3 & Desenvolvimento Pessoal dos Empregados & & & \\
\hline 6.4 & Capacitação Profissional dos Empregados & & & \\
\hline 6.5 & Inclusão de Trabalhadores Locais & & & \\
\hline 6.6 & Participação da Comunidade na Elaboração do Projeto & & & \\
\hline 6.7 & Orientação aos Moradores & obrigatório & & \\
\hline 6.8 & Educação Ambiental dos Moradores & & & \\
\hline 6.9 & Capacitação para Gestão do Empreendimento & & & \\
\hline 6.10 & Ações para Mitigação de Riscos Sociais & & & \\
\hline 6.11 & Ações para Geração de Emprego e Renda & & & \\
\hline
\end{tabular}

\subsection{PROCEL Edifica (Brasil)}

O Programa Nacional de Conservação de Energia Elétrica (PROCEL) foi uma iniciativa do Governo Brasileiro para racionalizar a produção e o consumo de energia elétrica, eliminar os desperdícios e reduzir os custos e investimentos no setor. Criado em 1985 pelos Ministérios de Minas e Energia e da Indústria e Comércio, e sob a gestão de uma Secretaria Executiva subordinada à Eletrobrás, em 1991, já como programa de Governo passou a ter maior abrangência. 
Como as construções são as grandes vilãs no consumo de energia em todo o mundo, sentiu-se a necessidade de criar um programa voltado especificamente para esta área, e assim, em 2003 criou-se o PROCEL Edifica, em conjunto com o Ministério de Minas e Energia, o Ministério das Cidades, universidades, centros de pesquisa e entidades das áreas governamental, tecnológica, econômica e de desenvolvimento, além do setor da construção civil.

O sistema de avaliação do desempenho energético das edificações possui três programas distintos disponíveis:

- Edifícios residenciais, que são subdivididos em: Unidades Habitacionais autônomas (UHs); Edificações Multifamiliares e Áreas Comuns.

- Edifícios comerciais

- Edifícios de serviços e públicos.

Dentro de cada programa citado acima, são avaliadas diversas categorias. No caso dos edifícios comerciais e de serviços e públicos, são analisadas a envoltória, iluminação e condicionamento de ar. Enquanto nos edifícios residências, acrescentam-se as avaliações do sistema de aquecimento de água, além dos sistemas presentes nas áreas comuns dos edifícios multifamiliares, como iluminação, elevadores, bombas centrífugas etc.

A avaliação dos projetos é realizada em duas etapas: na fase de projeto e após a construção do edifício. Um projeto pode ser avaliado pelo método prescritivo ou pelo método da simulação, enquanto o edifício construído deve ser avaliado através de inspeção in loco.

Segundo o PBE (Programa Brasileiro de Etiquetagem Edifica), a etiqueta (Figuras 3.6 e 3.7) é o Selo de Conformidade que evidencia o atendimento a requisitos de desempenho (e, em alguns casos, adicionalmente, também de segurança) estabelecidos em normas e regulamentos técnicos. 


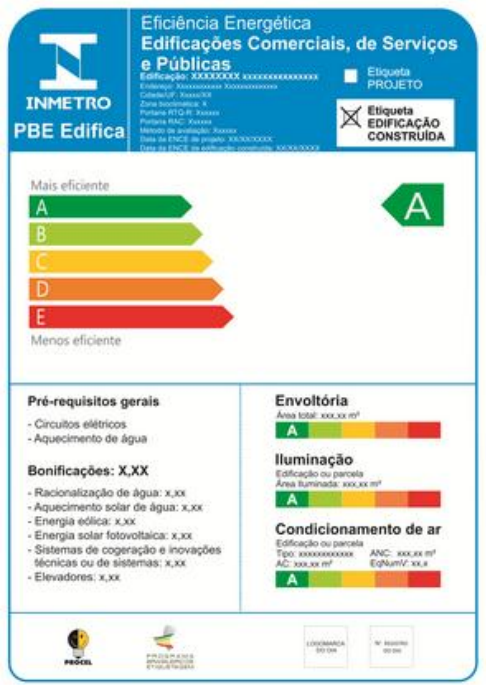

Figura 3.6 - Etiqueta de Eficiência Energética Edifícios Comerciais, de Serviços e Públicos.

Fontes: <creato.com.br> $<$ pbeedifica.com.br>. Acesso em 04 dez.

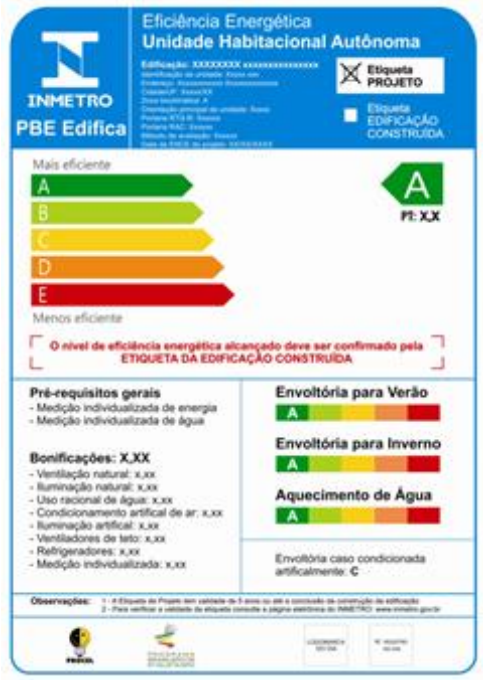

Figura 3.7 - Etiqueta de Eficiência Energética Unidade Habitacional Autônoma.

e Fontes: <creato.com.br> e <pbeedifica.com.br>. Acesso em 04 dez. 2014

Conforme orientações do PROCEL, estas etiquetas devem ser emitidas por Organismo de Inspeção Acreditado (OIA) pelo Inmetro, para Eficiência Energética em Edificações - OIAEEE. Pelo Centro Brasileiro de Informação de Eficiência Energética, as publicações técnicas relacionadas à Etiquetagem em Edifícios são:

\section{RTQ-C}

Requisitos Técnicos da Qualidade para o Nível de Eficiência Energética em Edifícios Comerciais, de Serviços e Públicos. Portaria 372/2010, onde define o documento que especifica os requisitos técnicos, bem como os métodos para classificação de edifícios comerciais, de serviços e públicos quanto à eficiência energética. Os edifícios submetidos a este RTQ devem atender às normas da Associação Brasileira de Normas Técnicas (ABNT) vigentes e aplicáveis.

\section{RTQ-R}

Regulamento Técnico da Qualidade para o Nível de Eficiência Energética em Edificações Residenciais. Tratando-se de Edificações Residenciais, o documento especifica requisitos técnicos, bem como os métodos para a classificação de edificações residenciais quanto à eficiência energética. As edificações submetidas a este RTQ devem atender às normas da Associação Brasileira de Normas Técnicas (ABNT) vigentes e aplicáveis. 
RAC

Requisitos de Avaliação da Conformidade para Eficiência Energética de Edificações. Documento que Estabelece os critérios para o Programa de Avaliação da Conformidade de Eficiência Energética de Edificações, através do mecanismo da Inspeção, objetivando a concessão da Etiqueta Nacional de Conservação de Energia - ENCE, de acordo com os Regulamentos Técnicos da Qualidade para este objeto, e visando estimular a concepção de edificações mais eficientes.

A tabela 3.8, apresenta um resumo do RTQ-R 2013, versão 1 para edificações residenciais (LANNOY, 2013).

Tabela 3.8 - Tabela Resumo PROCEL Edifica

\begin{tabular}{|c|c|c|c|c|}
\hline 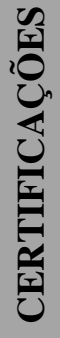 & 它 & 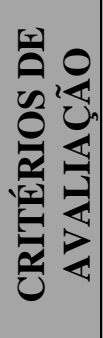 & PRÉ REQUISITOS & OBJETIVO \\
\hline \multirow{3}{*}{ 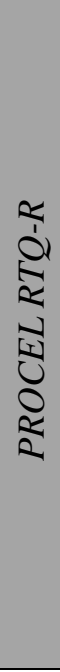 } & \multirow{3}{*}{ 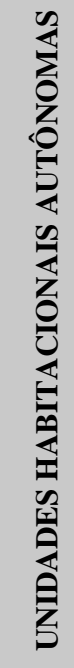 } & \multirow{3}{*}{ 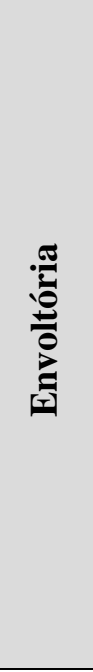 } & $\begin{array}{l}\text { Transmitância térmica, } \\
\text { capacidade térmica e } \\
\text { absortância solar das } \\
\text { superfícies }\end{array}$ & $\begin{array}{l}\text { Devem ser atendidos de acordo com a Zona Bioclimática em que } \\
\text { a edificação se localiza. Obs.: Paredes referem-se a elementos } \\
\text { opacos, não incluem as aberturas e são usadas principalmente no } \\
\text { cálculo da transmitância térmica e absortância (assim como } \\
\text { as aberturas). Já as fachadas referem-se a todos os elementos } \\
\text { que compõem o fechamento do edifício, incluindo elementos } \\
\text { opacos e translúcidos. }\end{array}$ \\
\hline & & & Ventilação natural & $\begin{array}{l}\text { a) Percentual de áreas mínimas de abertura para ventilação. b) } \\
\text { Ventilação cruzada. }\end{array}$ \\
\hline & & & Iluminação natural & $\begin{array}{l}\text { O acesso à iluminação natural em ambientes de permanência } \\
\text { prolongada deve ser garantido por uma ou mais aberturas para o } \\
\text { exterior. A soma das áreas de aberturas para iluminação natural } \\
\text { de cada ambiente deve corresponder a no mínimo 12,5\% da área } \\
\text { útil do ambiente. }\end{array}$ \\
\hline
\end{tabular}




\begin{tabular}{|c|c|c|c|c|}
\hline & & & $\begin{array}{l}\text { Sistema de aquecimento } \\
\text { solar }\end{array}$ & $\begin{array}{l}\text { Os coletores solares devem ser instalados com orientação e } \\
\text { ângulo de inclinação conforme especificações, manual de } \\
\text { instalação e projeto. }\end{array}$ \\
\hline & & $\stackrel{g}{\Xi}$ & $\begin{array}{l}\text { Sistema de aquecimento } \\
\text { a gás }\end{array}$ & $\begin{array}{l}\text { Os aquecedores a gás do tipo instantâneo e de acumulação } \\
\text { devem possuir ENCE A ou B. Nos casos em que seja utilizado } \\
\text { reservatório de água quente, este deve ter isolamento térmico e } \\
\text { capacidade de armazenamento compatível com o } \\
\text { dimensionamento proposto a seguir. }\end{array}$ \\
\hline & & 苞 & Bombas de calor & $\begin{array}{l}\text { Sistemas de aquecimento de água utilizando bombas de calor } \\
\text { recebem eficiência de acordo com o coeficiente de performance } \\
\text { (COP), medindo de acordo as normas ASHRAE Standard 146, } \\
\text { ASHRAE } 13256 \text { ou AHRI } 1160 \text {. }\end{array}$ \\
\hline 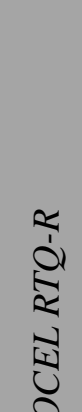 & 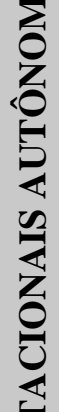 & 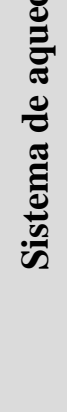 & $\begin{array}{l}\text { Sistema de aquecimento } \\
\text { elétrico }\end{array}$ & $\begin{array}{l}\text { Aos sistemas de aquecimento de água com aquecedores elétricos } \\
\text { de passagem, chuveiros elétricos e torneiras elétricas é atribuída } \\
\text { eficiência em função da potência do aparelho, desde que façam } \\
\text { parte do PBE. Aos aquecedores elétricos de hidromassagem é } \\
\text { atribuída eficiência em função da potência do aparelho, desde } \\
\text { que façam parte do PBE. Os aquecedores elétricos de água por } \\
\text { acumulação (boiler) devem possuir ENCE e estar de acordo com } \\
\text { as normas técnicas brasileiras para aquecedores elétricos por } \\
\text { acumulação. Os aquecedores devem possuir timer para evitar } \\
\text { seu uso no horário de ponta. }\end{array}$ \\
\hline & 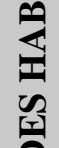 & & Caldeiras a óleo & $\begin{array}{l}\text { Caldeiras que utilizam como combustível fluido líquido como } \\
\text { óleo diesel ou outros derivados de petróleo receberão } \\
\text { classificação nível E. }\end{array}$ \\
\hline & 萦 & 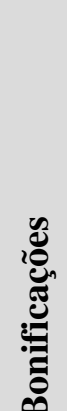 & Ventilação natural & $\begin{array}{l}\text { As UHs de até dois pavimentos devem comprovar a existência } \\
\text { de porosidade mínima de } 20 \% \text { em pelo menos duas fachadas } \\
\text { com orientações distintas, expressa pela relação entre a área } \\
\text { efetiva de abertura para ventilação e a área da fachada (a } \\
\text { verificação da porosidade é feita para cada fachada). Em } \\
\text { edifícios verticais, essa porosidade pode ser reduzida em função } \\
\text { da altura das aberturas de entrada do vento, medida em relação } \\
\text { ao nível médio do meio-fio e o centro geométrico dessas } \\
\text { aberturas, multiplicando-a pelo valor do coeficiente de redução } \\
\text { de porosidade obtido na Tabela fornecida para esta categoria. }\end{array}$ \\
\hline & & & Iluminação natural & $\begin{array}{l}\text { a) Profundidade (conforme tabela fornecida nesta categoria) de } \\
\text { ambientes com iluminação natural proveniente de aberturas } \\
\text { laterais. b) Refletância do teto. }\end{array}$ \\
\hline & & & Uso racional da água & $\begin{array}{l}\text { As UHs devem possuir combinação de sistemas de uso de água } \\
\text { da chuva e equipamentos economizadores. }\end{array}$ \\
\hline
\end{tabular}




\begin{tabular}{|c|c|c|c|c|}
\hline \multirow{7}{*}{ 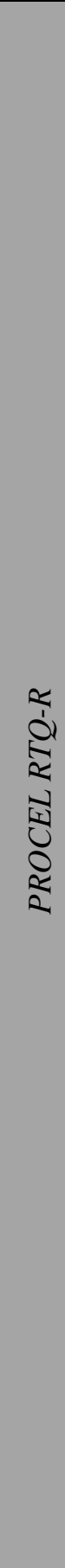 } & \multirow{5}{*}{ 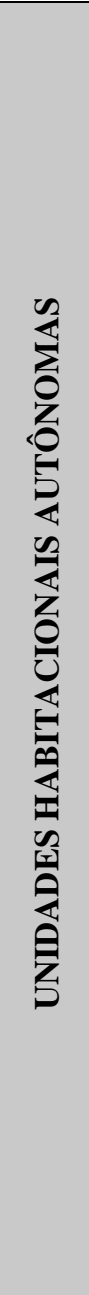 } & \multirow{5}{*}{ 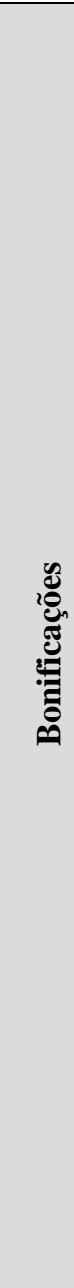 } & $\begin{array}{l}\text { Condicionamento } \\
\text { artificial de ar }\end{array}$ & $\begin{array}{l}\text { A envoltória da UH deve atingir nível A de eficiência quando } \\
\text { condicionada artificialmente. Condicionadores de ar do tipo } \\
\text { janela e do tipo Split devem possuir ENCE A ou Selo PROCEL } \\
\text { e estar de acordo com as normas brasileiras de condicionadores } \\
\text { de ar domésticos. Condicionadores de ar do tipo central ou } \\
\text { condicionadores não regulamentados pelo INMETRO devem } \\
\text { atender aos parâmetros definidos nos Requisitos Técnicos da } \\
\text { Qualidade para o Nível de Eficieincia Energética de Edifícios } \\
\text { Comerciais, de Serviços e Públicos (RTQ-C), publicados pelo } \\
\text { INMETRO; As cargas térmicas de projeto do sistema de } \\
\text { aquecimento e resfriamento de ar devem ser calculadas de } \\
\text { acordo com normas e manuais de engenharia, de comprovada } \\
\text { aceitação nacional ou internacional, com publicação posterior ao } \\
\text { ano de 2000, como por exemplo, o ASRAE Handbook of } \\
\text { Fundamentals. }\end{array}$ \\
\hline & & & Iluminação artificial & $\begin{array}{l}\text { As UHs devem possuir } 50 \% \text { das fontes de iluminação artificial } \\
\text { com eficiência superior a } 75 \mathrm{~lm} / \mathrm{W} \text { ou com Selo PROCEL em } \\
\text { todos os ambientes; as UHs devem possuir } 100 \% \text { das fontes de } \\
\text { iluminação artificial com eficiência superior a } 75 \mathrm{~lm} / \mathrm{W} \text { ou com } \\
\text { Selo PROCEL em todos os ambientes. }\end{array}$ \\
\hline & & & Ventiladores de teto & $\begin{array}{l}\text { As UHs devem possuir instalados ventiladores de teto com Selo } \\
\text { PROCEL e garantir as condições adequadas de instalação } \\
\text { conforme recomendações do fabricante. }\end{array}$ \\
\hline & & & Refrigeradores & $\begin{array}{l}\text { As UHs devem possuir instalados refrigeradores com ENCE } \\
\text { nível A ou Selo PROCEL e garantir as condições adequadas de } \\
\text { instalação conforme recomendações do fabricante. }\end{array}$ \\
\hline & & & Medição individualizada & $\begin{array}{l}\text { Caso o sistema de aquecimento da água na edificação seja } \\
\text { partilhado por mais de uma UH, este deve possibilitar medição } \\
\text { individualizada. }\end{array}$ \\
\hline & 焉起 & \multicolumn{3}{|c|}{$\begin{array}{l}\text { A classificação do nível de eficiência de edificações unifamiliares é equivalente ao resultado } \\
\text { da classificação da unidade habitacional autônoma. }\end{array}$} \\
\hline & 焉䎡 & \multicolumn{3}{|c|}{$\begin{array}{l}\text { A classificação do nível de eficiência de edificações multifamiliares é o resultado da } \\
\text { ponderação da classificação de suas unidades habitacionais autônomas pela área útil das } \\
\text { UHs, excluindo terraços e varandas. }\end{array}$} \\
\hline
\end{tabular}




\begin{tabular}{|c|c|c|c|c|}
\hline & & & Iluminação artificial & $\begin{array}{l}\text { Devem ser respeitados os critérios da tabela fornecida para } \\
\text { esta categoria. }\end{array}$ \\
\hline & & 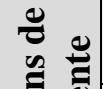 & Bombas Centrífugas & $\begin{array}{l}\text { As bombas centrífugas instaladas na edificação devem possuir } \\
\text { ENCE. }\end{array}$ \\
\hline & & 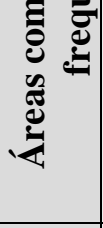 & Elevadores & $\begin{array}{l}\text { Os elevadores devem ter eficiência atribuída em função da } \\
\text { demanda específica de energia, que é baseada na demanda de } \\
\text { energia em stand bye na demanda em viagem. Para tanto, } \\
\text { deve-se definir a categoria de uso do elevador dentre as quatro } \\
\text { categorias apresentadas na tabela para esta categoria. }\end{array}$ \\
\hline & & & $\begin{array}{l}\text { Envoltória de áreas } \\
\text { comuns de uso eventual }\end{array}$ & $\begin{array}{l}\text { Caso as áreas comuns de uso eventual sejam construídas } \\
\text { separadas das edificações residenciais, a sua envoltória deve } \\
\text { atender aos pré-requisitos de transmitância térmica, } \\
\text { capacidade térmica e absortância solar das superfícies. }\end{array}$ \\
\hline & & & Iluminação artificial & $\begin{array}{l}\text { As bombas centrífugas instaladas na edificação devem possuir } \\
\text { ENCE. }\end{array}$ \\
\hline & $\sum_{S}^{\sum}$ & 矛 & $\begin{array}{c}\text { Equipamentos } \\
\text { (Condicionadores de ar e } \\
\text { Eletrodomésticos e } \\
\text { equipamentos) }\end{array}$ & Devem possuir ENCE. \\
\hline 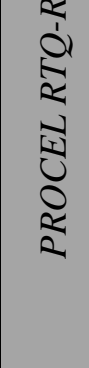 & 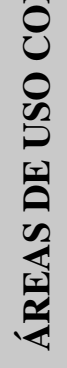 & 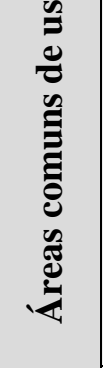 & $\begin{array}{l}\text { Sistemas de aquecimento } \\
\text { de água }\end{array}$ & $\begin{array}{l}\text { a) O sistema de aquecimento de água de chuveiros, torneiras e } \\
\text { hidromassagem deve ter sua classificação obtida conforme já } \\
\text { descrito anteriormente. b) Sistema de aquecimento de } \\
\text { piscinas: para obtenção do nível A, o sistema de aquecimento } \\
\text { de água de piscinas deve ser feito através de aquecimento } \\
\text { solar, a gás ou por bomba de calor e deve atender aos pré- } \\
\text { requisitos gerais e aos pré-requisitos para sistema de } \\
\text { aquecimento solar ou por bomba de calor, dependendo do } \\
\text { sistema utilizado. }\end{array}$ \\
\hline & & & Sauna & $\begin{array}{l}\text { Para obtenção do nível A, o aquecimento da sauna deve ser } \\
\text { realizado por equipamentos a gás GLP, gás natural ou lenha e } \\
\text { as paredes e portas devem possuir isolamento térmico mínimo } \\
\text { de } 0,5 \mathrm{~m}^{2} \mathrm{k} / \mathrm{W} \text {. Saunas a gás ou a lenha sem o referido } \\
\text { isolamento térmico receberão nível C. Saunas com } \\
\text { aquecimento elétrico receberão classificação nível E. }\end{array}$ \\
\hline & & 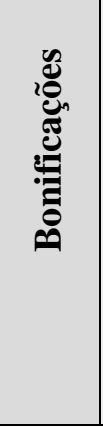 & Uso racional da água & $\begin{array}{l}\text { A bonificação pode ser obtida com a combinação de sistemas } \\
\text { e equipamentos que racionalizem o uso da água, tais como: } \\
\text { torneira com arejadores e/ou temporizadores, chuveiros com } \\
\text { regulador de pressão, sanitários com descarga de duplo } \\
\text { acionamento, mictórios com sensores, reuso de águas cinza e } \\
\text { aproveitamento de água pluvial para descarga de bacias } \\
\text { sanitárias, irrigação de jardins, limpeza de áreas externas e } \\
\text { fachadas e uso em torneiras externas. Para tanto, deve-se } \\
\text { comprovar economia mínima de } 40 \% \text { no consumo anual de } \\
\text { água, considerando o dimensionamento para sistemas não } \\
\text { economizadores nas mesmas condições de uso. }\end{array}$ \\
\hline
\end{tabular}




\begin{tabular}{|c|c|c|c|c|}
\hline$\underbrace{\infty}_{\substack{1 \\
2}}$ & $\stackrel{\ominus}{\mathscr{W}}$ & 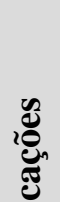 & $\begin{array}{l}\text { Iluminação natural em } \\
\text { áreas comuns de uso } \\
\text { frequente }\end{array}$ & $\begin{array}{l}\text { Garagens internas mais } 75 \% \text { dos ambientes internos das áreas } \\
\text { comuns de uso frequente devem apresentar dispositivos de } \\
\text { iluminação natural como janelas, iluminação zenital ou de } \\
\text { função similar, com área de no mínimo } 1 / 10 \text { da área do piso } \\
\text { do ambiente. }\end{array}$ \\
\hline 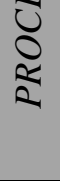 & $\underset{4}{2}$ & 配 & $\begin{array}{l}\text { Ventilação natural em } \\
\text { áreas comuns de uso } \\
\text { frequente }\end{array}$ & $\begin{array}{l}\text { Garagens mais } 75 \% \text { dos ambientes internos das áreas comuns } \\
\text { de uso frequente devem possuir aberturas voltadas para o } \\
\text { exterior com área de abertura efetiva para ventilação mínima } \\
\text { de } 1 / 12 \text { da área do piso do ambiente. }\end{array}$ \\
\hline
\end{tabular}

Fonte: LANNOY, 2013

Ainda sobre o contexto da eficiência energética das edificações, é possível ressaltar as Normas Brasileiras desenvolvidas pela ABNT (Associação Brasileira de Normas Técnicas): NBR 15220 e NBR 15575.

A NBR 15220, Desempenho Térmico de Edificações, destaca-se a terceira parte (ABNT, 2005c), que estabelece o Zoneamento Bioclimático Brasileiro, onde foi formulado um conjunto de recomendações técnico-construtivas para cada uma das oito zonas bioclimáticas, objetivando otimizar o desempenho térmico das edificações, através de sua melhor adequação climática. Já a NBR 15575, Edifícios Habitacionais de até 5 pavimentos - Desempenho, estabelece que as edificações habitacionais devem reunir características que atendam às exigências de desempenho térmico considerando sua região de implantação e as respectivas características bioclimáticas (Figuras 4.8 e 4.9), conforme observado por Fagundes (2014).

\begin{tabular}{c|c}
\hline Nivel de Eficiência & EqNum \\
\hline A & 5 \\
\hline B & 4 \\
\hline C & 3 \\
\hline D & 2 \\
\hline E & 1 \\
\hline \multicolumn{2}{|c}{}
\end{tabular}

Fonte: INMETRO, 2010b, p.18.

\begin{tabular}{c|c}
\hline Pontuação (PT) & Nivel de Eficiência \\
\hline $\mathrm{PT} \geq 4,5$ & $\mathrm{~A}$ \\
\hline $3,5 \leq \mathrm{PT}<4,5$ & $\mathrm{~B}$ \\
\hline $2,5 \leq \mathrm{PT}<3,5$ & $\mathrm{C}$ \\
\hline $1,5 \leq \mathrm{PT}<2,5$ & $\mathrm{D}$ \\
\hline $\mathrm{PT}<1,5$ & $\mathrm{E}$ \\
\hline
\end{tabular}

Fonte: INMETRO, 2010b, p.19.

Figura 3.9 - Classificação do nível de eficiência de acordo com a pontuação obtida.
Figura 3.8 - Equivalente Numérico para cada nível de Eficiência.

Fonte: FAGUNDES, 2014.

Nos capítulos seguintes, serão apresentadas as justificativas e as análises comparativas entre os selos estudados neste trabalho e a construção do exercício de avaliação da sustentabilidade referente aos tipos de telhas para edificações residenciais.

Milena Lannoy (2013) realizou um levantamento para compor os parâmetros de avaliação aplicados em materiais de acabamento, com aplicação em pisos e revestimentos. 
Neste estudo, serão avaliados estes parâmetros para coberturas com ênfase às telhas, os quais, segundo a autora, foram pesquisados os critérios, categorias, e classificações de análise adotada pelas principais ferramentas de avaliação da sustentabilidade atuantes no Brasil, Normas da ABNT e órgãos fiscalizadores. 


\section{CAPÍTULO 4}

\section{JUSTIFICATIVA DA ESCOLHA DOS SELOS ECOLÓGICOS E DAS CERTIFICAÇÕES PARA ANÁLISE DAS COBERTURAS - TIPOS DE TELHAS E ANÁLISE COMPARATIVA E SEMELHANÇA DOS SELOS E EXERCÍCIO DE AVALIAÇÃO DA SUSTENTABILIDADE PARA COBERTURAS-TIPOS DE TELHAS}

\subsection{Justificativa da escolha dos selos ecológicos e das certificações}

A escolha dos selos ecológicos e das certificações foi feita tendo como critério preponderante aspectos sustentáveis na construção civil. Cada selo tem suas especificidades, porém têm o mesmo objetivo. Todos tratam da sustentabilidade em obras civis de uma maneira geral, da fabricação ao acabamento, entretanto, somente a cobertura será avaliada na presente dissertação. Nesta avaliação, criamos tabelas de estudo e desenvolvimento (capítulos 4 e 5) onde podemos observar cada atributo especificamente.

Esclarecendo a escolha de cada selo, começamos pelo BREEAM. Um dos motivos de sua escolha foi por verificar desde as compras sustentáveis, onde o modo de produção de cada telha influencia na qualificação da mesma, até sua durabilidade. Observa-se também, itens de relevância de conforto térmico e visual. Podemos citar um exemplo que se enquadra muito bem tanto na prática sustentável da construção quanto no uso cotidiano e permanência: as telhas de fibras vegetais.

Em relação ao LEED, vimos que este selo tem um papel significante na qualificação dos materiais e dá ênfase aos créditos regionais, sendo o único a abordar o tema. Verificamos que as telhas de concreto podem ser um exemplo interessante no que se refere a este critério, pois possuem coloração diferente de acordo com cada região, tendo tons mais escuros para ambientes frios e tons mais claros para regiões mais quentes, absorvendo mais ou menos calor. Mas já não é avaliado em relação aos resíduos, o que justifica a escolha de outros selos concomitantemente. Porém, outras questões de gerenciamento de resíduo da construção são exigidas na análise do LEED, avaliando as telhas que menos geram resíduos. Neste caso, há coincidência entre os critérios de análise do BREEAM, do LEED e do AQUA.

O selo AQUA foi escolhido por ser primeiro método brasileiro a certificar a qualidade ambiental. Avalia por exemplo, o conforto acústico assim como o LEED, podendo ser observada nas telhas apresentadas com as respectivas notas. Entretanto, não possui quesitos de avaliação do transporte da telha ao seu destino final como o BREEAM tem. 
Já selo CASA AZUL, da Caixa Econômica Federal, foi escolhido por ter sido desenvolvido para a realidade da construção habitacional brasileira, conforme informa o site da Caixa. Ele tem como um dos focos, o aproveitamento do aquecimento solar, que também é um dos critérios de avaliação do PROCEL EDIFICA.

O selo que se mais diferencia dos demais nos quesitos abordados é o PROCEL EDIFICA. Este tem sua análise baseada na racionalização de energia e consumo elétrico. Nos termos das telhas estudadas, este selo foi escolhido para que pudesse ser feito uma análise principalmente das telhas fotovoltaicas, que utilizam em suas superfícies, placas de aquecimento solar, podendo ser avaliadas e qualificadas tanto na transmitância térmica quanto na absortância solar.

Vemos que todos os selos possuem o mesmo contexto geral visando melhor qualidade do produto diminuindo o impacto ambiental. Muitos dos atributos e critérios de avaliação destes selos são coincidentes, mas a importância da escolha deu-se porque eles se complementam. A interação dos selos propicia uma melhor avaliação das telhas e visa melhorar a qualidade de vida das pessoas. No esquema abaixo, sintetiza-se os principais indicadores nos devidos selos.

Quanto ao quantitativo de atributos e critérios de avaliação utilizados no estudo das telhas, fizemos uma combinação dos selos optando pelos que mais se adequaram ás telhas. A tabela 4.3- Critérios de Avaliação - Tipos de Telhas mostra os atributos e critérios selecionados. Fazendo um levantamento, obtivemos ao todo 70 critérios de avaliação utilizados para análise das telhas, distribuídos da seguinte forma: BREEAM com 20 critérios de avaliação, LEED com 18 critérios, CASA AZUL com 16 critérios, AQUA com 14 critérios e por último o PROCEL EDIFICA, com 2 critérios.

Outra justificativa da escolha dos selos ecológicos foi a tentativa de oferecer uma ferramenta que verifique vários critérios de avaliação da sustentabilidade e que dê conscientização dos profissionais da construção civil e interessados de que existem métodos eficazes de tornar uma obra sustentável mitigando os efeitos danosos causados pela atividade ao meio ambiente. 


\subsection{Análise comparativa e semelhança dos selos}

Os sistemas de categorização e certificação ou selo ecológico proporcionam uma escala para que se possa avaliar a incorporação de estratégias sustentáveis a uma edificação em comparação com edificações mais tradicionais. O surgimento dos sistemas de certificação não é recente, tendo alguns dos selos mais de 20 anos. As diferenças entre estes sistemas vão de aplicações específicas para determinada região até avaliação de impacto versus desempenho ou consideração de operações e manutenção como parte do sistema.

Os sistemas apresentados ao longo deste trabalho (BREEAM, LEED, AQUA, CASA AZUL e PROCEL EDIFICA) são análises estatísticas de desempenho de edifícios de referência para a criação de uma nova meta com valores superiores. Estes sistemas se diferenciam, especialmente, em relação à metodologia de avaliação empregada. Muitos atributos se coincidem e muitos deles são específicos para cada tipo de selo ecológico.

Segundo a Inovatch Engenharia, para os sistemas LEED, BREEAM, CASA AZUL E PROCEL EDIFICA, a avaliação é feita por desempenho, baseando-se na gestão e no processo construtivo como um todo, sem necessariamente priorizar ou determinar diretrizes específicas para atingir os níveis desejados de sustentabilidade. Todas as categorias devem apresentar um bom índice de desempenho (igual ou superior ao normatizado) e resultados que sejam efetivos. Já para os sistemas AQUA e BREEAM, apesar das diferentes metodologias e estratégias empregadas nos sistemas de certificação, existe uma série de indicadores que se aplicam a elas. Os indicadores comuns para a avaliação de desempenho e classificação de edifícios sustentáveis são determinados por uma organização internacional sem fins lucrativos, a SB Alliance (Aliança dos Edifícios Sustentáveis).

Um aspecto importante a ser considerado quanto à escolha do sistema de certificação é a questão da adaptabilidade local. A maioria dos sistemas utilizados no Brasil foi importada de outros países, o que, dependendo do caso, pode prejudicar o desempenho das soluções adotadas. Isso porque, para obter resultados que sejam sustentáveis de fato, é imprescindível levar em consideração as especificidades de cada região, inclusive o terreno, o bairro, a cidade e o país.

A Tabela 4.1 apresenta um comparativo entre os dois selos utilizados no Brasil, o GBC Brasil Casa e o Selo Casa Azul da Caixa, têm-se as seguintes semelhanças: 


\section{Tabela 4.1 Comparativo entre o Referencial GBC Brasil Casa e o Selo Casa Azul Caixa (Fonte adaptada de: GBCB, 2012 e JOHN; PRADO, 2010.).}

\begin{tabular}{|c|c|c|}
\hline & Referencial GBC Brasil Casa & Selo Casa Azul Caixa \\
\hline \multirow{2}{*}{ 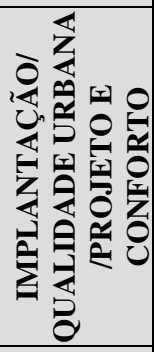 } & \multirow{2}{*}{$\begin{array}{l}\text { Conectividade com o entorno; localização em área } \\
\text { previamente desenvolvida; proximidade à rede de } \\
\text { transportes públicos; canteiro de obras de baixo } \\
\text { impacto ambiental; redução dos efeitos de ilha de } \\
\text { calor; controle de pragas de baixo impacto } \\
\text { ambiental; paisagismo adaptado às condições } \\
\text { climáticas locais. }\end{array}$} & $\begin{array}{l}\text { Infraestrutura; impactos; melhorias no entorno; } \\
\text { recuperação de áreas degradadas; reabilitação de imóveis. }\end{array}$ \\
\hline & & $\begin{array}{l}\text { Paisagismo; flexibilidade de projeto; relação com a } \\
\text { vizinhança; coleta seletiva; equipamentos públicos; } \\
\text { tratamento da envoltória - ventilação, temperatura e } \\
\text { iluminação; adequação à topografia do terreno. }\end{array}$ \\
\hline 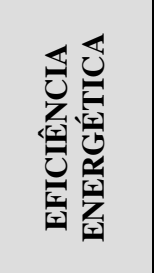 & $\begin{array}{l}\text { Tratamento da envoltória; sistema de aquecimento } \\
\text { solar eficiente; qualidade das instalações elétricas; } \\
\text { iluminação artificial eficiente; gerenciamento dos } \\
\text { gases refrigerantes; geração de energia renovável; } \\
\text { equipamentos elétricos eficientes; } \\
\text { comissionamento dos sistemas e medição e } \\
\text { verificação. }\end{array}$ & $\begin{array}{l}\text { Especificação de lâmpadas eficientes; eficiência em } \\
\text { sistemas de aquecimento; sistemas de elevadores } \\
\text { eficientes; equipamentos elétricos eficientes e fontes } \\
\text { alternativas de energia. }\end{array}$ \\
\hline 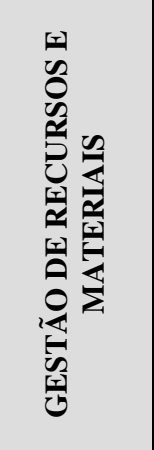 & $\begin{array}{l}\text { Gestão de resíduos da construção civil; uso de } \\
\text { madeira legalizada ou certificada; gestão eficiente } \\
\text { da construção e da operação; especificação de } \\
\text { materiais e sistemas construtivos que apresentem } \\
\text { em sua composição materiais de reuso, materiais } \\
\text { fabricados, extraídos e produzidos regionalmente, } \\
\text { materiais com conteúdo reciclado, materiais } \\
\text { recicláveis e materiais rapidamente renováveis; } \\
\text { controle de materiais contaminantes; especificação } \\
\text { de materiais certificados; desmontabilidade e } \\
\text { redução de resíduos - elementos estruturais e não } \\
\text { estruturais. }\end{array}$ & $\begin{array}{l}\text { Coordenação modular; qualidade dos materiais e } \\
\text { componentes construtivos; componentes industrializados; } \\
\text { reutilização de formas e elementos de escoramento; gestão } \\
\text { dos resíduos das atividades de construção civil; otimização } \\
\text { da dosagem do concreto; utilização de cimento com } \\
\text { especificação adequada; reaproveitamento de resíduos para } \\
\text { pavimentação; manutenibilidade da fachada; especificação } \\
\text { de madeira certificada ou proveniente de manejo } \\
\text { sustentável. }\end{array}$ \\
\hline 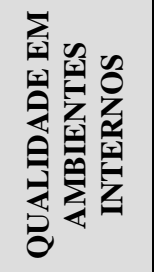 & $\begin{array}{l}\text { Controle de emissão de gases de combustão; } \\
\text { exaustão localizada; filtragem do ar exterior; } \\
\text { controle da umidade; conforto ambiental interno; } \\
\text { automação da exaustão; distribuição dos sistemas } \\
\text { de ar; controle de partículas contaminantes; } \\
\text { proteção contra poluentes provenientes da } \\
\text { garagem; controle de radônio; conforto acústico. }\end{array}$ & \\
\hline 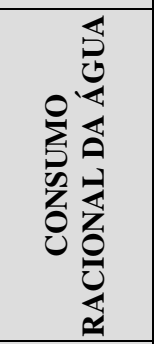 & $\begin{array}{l}\text { Medição e gerenciamento de água fria; } \\
\text { especificação de equipamentos eficientes - para } \\
\text { sistemas de descarga, torneiras e misturadores de } \\
\text { lavatórios e chuveiros; medição setorizada de áreas } \\
\text { complementares e fontes alternativas; sistema de } \\
\text { irrigação eficiente. }\end{array}$ & $\begin{array}{l}\text { Medição individualizada, uso de dispositivos } \\
\text { economizadores - sistemas de descargas, arejadores e } \\
\text { sistemas reguladores de vazão, gestão de águas pluviais - } \\
\text { reuso, captação e infiltração, áreas permeáveis. }\end{array}$ \\
\hline 空 & $\begin{array}{l}\text { Desenho universal; boas práticas sociais para: } \\
\text { projeto, obra, operação e manutenção. }\end{array}$ & $\begin{array}{l}\text { Educação de empregados, moradores e gestores para gestão } \\
\text { de resíduos, educação ambiental; capacitação profissional; } \\
\text { desenvolvimento pessoal dos trabalhadores; mitigação de } \\
\text { riscos sociais; estratégias para a geração de emprego e } \\
\text { renda; inclusão de trabalhadores locais e participação da } \\
\text { comunidade no projeto. }\end{array}$ \\
\hline
\end{tabular}




\begin{tabular}{|l|l|l|}
\hline & $\begin{array}{l}\text { Projeto integrado e planejamento; gestão da } \\
\text { qualidade visando à durabilidade; elaboração de } \\
\text { manual do usuário; análise do ciclo de vida; }\end{array}$ \\
inovação em projeto.
\end{tabular}

Na tabela comparativa entre o Referencial GBC Brasil Casa e o Selo Casa Azul da Caixa, nota-se que o sistema de certificação da GBC Brasil Casa, em sua versão adaptada à realidade brasileira, além de incorporar os critérios de verificação do desempenho energético do Programa PROCEL Edifica (BRASIL, 2010) para o tratamento da envoltória, há ainda a preocupação com a eficiência do sistema de aquecimento de água, e a utilização de madeira legalizada, incorporando aspectos relacionados à qualidade em ambientes internos, consolidados nos Estados Unidos pela Agência de Proteção Ambiental (Environmental Protection Agency - EPA) e propostos pelo sistema de certificação LEED for Homes (USGBC, 2006), sendo estes: preocupação com a qualidade do ar ambiental interno e em garagens, gestão de fluidos refrigerantes, controle da umidade em ambientes internos, orientações para proteção contra radônio e controle dos contaminantes.

O referencial AQUA para edificações habitacionais (FCAV, 2013), que foi publicado inicialmente em 2010 e revisado recentemente em 2013, é direcionado a empreendimentos habitacionais com uma ou mais edificações, e também se aplicaria, em tese, a residências unifamiliares, embora deva ser analisada sua viabilidade financeira. A revisão recentemente publicada incorpora orientações do programa de etiquetagem PROCEL Edifica propostas no Regulamento de Avaliação da Conformidade do Nível de Eficiência Energética de Edificações Residenciais - RAC-R (BRASIL, 2010) e apresentadas na norma NBR 15575: 2013 - Edifícios habitacionais: desempenho (ABNT, 2013). (Inovatech Engenharia)

\subsection{Exercício de avaliação da sustentabilidade para tipos de telhas}

O processo de documentação (check lists) para a comprovação do atendimento aos critérios de desempenho ambiental e os trâmites envolvidos para a certificação variam conforme 
o sistema de certificação e os órgãos certificadores envolvidos, como já mencionado anteriormente.

Com base nos comparativos e sobre o material escolhido para estudo, será feita, a partir da interação das tabelas, a análise da sustentabilidade no quesito de coberturas com ênfase nos tipos de telhas.

Foram estudadas as tabelas dos principais métodos de avaliação usados no mercado brasileiro, descritos neste trabalho e analisados os critérios que avaliam as edificações unifamiliares e que enfocam a cobertura tendo como referência os tipos de telhas apresentados: fotovoltaicas, de tetra pak, vegetais, cerâmicas, telhas de garrafas Pet, de fibrocimento e de concreto.

A escolha do tema para o desenvolvimento deste trabalho deu-se como forma de continuação do estudo da sustentabilidade dos materiais de acabamento com foco em pisos e revestimentos feito por Lannoy (2013), incrementando a pesquisa para a área de cobertura com ênfase aos tipos de telha.

\subsubsection{A Construção do Exercício}

Com o estudo das Certificações Ambientais apresentadas no capítulo III e da Tabela de Interação dos critérios contidos nos selos BREEAM, LEED, AQUA, Selo CASA AZUL e PROCEL EDIFICA, foi criada 1 (uma) tabela com 43 critérios para o exercício de avaliação da sustentabilidade das sete telhas escolhidas. Como já descritos, esses critérios servirão de base para análise destas de telhas, tendo assim um parâmetro de comparação.

Lannoy (2013) desenvolveu uma tabela de interação dos critérios e dos atributos das Certificações Ambientais, a ser apresentada a seguir. A sua composição deu-se pela junção de todos os itens que apareceram nas certificações, associando 189 critérios encontrados, retirando os critérios repetidos, indicando-os com um "x" por já terem sidos mencionados. No momento da interação, em função das repetições, foi possível reconhecer 14 atributos, subdivididos em 157 critérios, para a formação de um novo parâmetro de avaliação.

A Tabela 4.2 apresenta uma interação dos critérios e atributos de todas as Certificações Ambientais, conforme observado por Lannoy (2013). 
Tabela 4.2 Interação entre as cinco ferramentas de avaliação da sustentabilidade.

\begin{tabular}{|c|c|c|c|c|c|c|c|c|}
\hline \multicolumn{9}{|c|}{ INTERAÇÕES ENTRE CERTIFICAÇÕES E NORMAS } \\
\hline & & 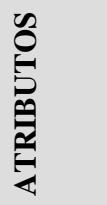 & CRITÉRIOS DE AVALIAÇÃO & $\sum_{\substack{\text { 空 } \\
\frac{c}{\alpha}}}$ & 㝙 & $\underset{\mho}{ٍ}$ & $\begin{array}{l}\text { 종 } \\
\text { О } \\
\text { 일 }\end{array}$ & $\frac{3}{3}$ \\
\hline \multirow{9}{*}{-} & \multirow{9}{*}{\multicolumn{2}{|c|}{ 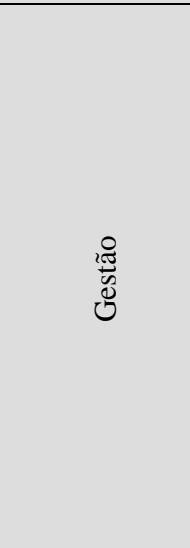 }} & Compras sustentáveis & $\mathbf{X}$ & & & & \\
\hline & & & Práticas sustentáveis da construção & $\mathbf{X}$ & & & & \\
\hline & & & Escolha integrada de produtos, sistemas e processos construtivos & & & $\mathbf{X}$ & & \\
\hline & & & Impactos da construção no solo & $\mathbf{X}$ & & & & \\
\hline & & & a participação dos interessados & $\mathbf{X}$ & & & & \\
\hline & & & Custo do ciclo de vida e planejamento de vida útil & $\mathbf{X}$ & & & & \\
\hline & & & Gestão de manutenção - permanência do desempenho ambiental & & & $\mathbf{X}$ & & \\
\hline & & & Medição individualizada - gás & & & & & $\mathbf{X}$ \\
\hline & & & Capacitação para Gestão do Empreendimento & & & & & $\mathbf{X}$ \\
\hline \multirow{5}{*}{$\mathrm{N}$} & \multirow{5}{*}{ 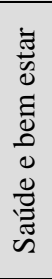 } & \multirow{5}{*}{ 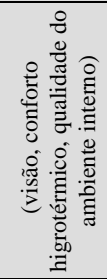 } & Conforto visual & $\mathbf{X}$ & & $\mathbf{X}$ & & \\
\hline & & & Qualidade interna do ar (conforto ambiental interno) & $\mathbf{X}$ & $\mathbf{X}$ & $\mathbf{X}$ & & \\
\hline & & & Conforto olfativo & & & $\mathbf{X}$ & & \\
\hline & & & Controle da umidade do ar & & $\mathbf{X}$ & $\mathbf{X}$ & & \\
\hline & & & Conforto térmico & $\mathbf{X}$ & & $\mathbf{X}$ & & \\
\hline \multirow{13}{*}{ N } & \multirow{13}{*}{ 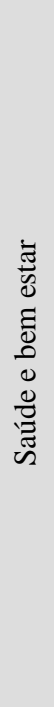 } & \multirow{13}{*}{ 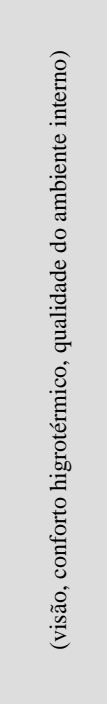 } & Qualidade da água & $\mathbf{X}$ & & $\mathbf{X}$ & & \\
\hline & & & Performance acústica (Conforto acústico) & $\mathbf{X}$ & & $\mathbf{X}$ & & \\
\hline & & & Saúde e segurança & $\mathbf{X}$ & & & & \\
\hline & & & Exaustão localizada - Automatizada & & $\mathbf{X}$ & & & \\
\hline & & & Distribuição dos Sistemas de Ar nos Ambientes & & $\mathbf{X}$ & & & \\
\hline & & & Filtragem do Ar exterior - Otimizada & & $\mathbf{X}$ & & & \\
\hline & & & Controle de Partículas Contaminantes & & $\mathbf{X}$ & $\mathbf{X}$ & & \\
\hline & & & Proteção de Poluentes Provenientes da Garagem & & $\mathbf{X}$ & & & \\
\hline & & & Proteção ao Radônio - Áreas de grande risco & & $\mathbf{X}$ & & & \\
\hline & & & Conforto Acústico & & $\mathbf{X}$ & $\mathbf{X}$ & & \\
\hline & & & Qualidade sanitária dos ambientes & & & $\mathbf{X}$ & & \\
\hline & & & Condicionamento artificial de ar eficiente & & & & $\mathbf{X}$ & \\
\hline & & & Ventiladores de teto & & & & & \\
\hline \multirow{7}{*}{$m$} & \multirow{7}{*}{\multicolumn{2}{|c|}{ 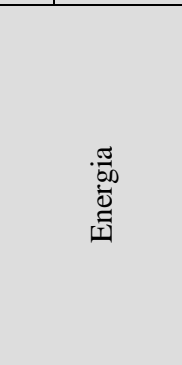 }} & Monitoramento (Gestão) de energia & $\mathbf{X}$ & & $\mathbf{X}$ & & \\
\hline & & & Redução das emissões de $\mathrm{CO} 2$ & $\mathbf{X}$ & & & & \\
\hline & & & Iluminação externa (Iluminação Natural de Áreas Comuns) & $\mathbf{X}$ & & $\mathbf{X}$ & $\mathbf{X}$ & \\
\hline & & & Baixo e zero emissões de carbono & $\mathbf{X}$ & & & & \\
\hline & & & Sistemas de energia eficientes de refrigeração & $\mathbf{X}$ & & $\mathbf{X}$ & & \\
\hline & & & Energia Eficiente em sistemas de transporte & $\mathbf{X}$ & & & & \\
\hline & & & Incentivo e pesquisas para redução da emissão de $\mathrm{CO} 2$ & $\mathbf{X}$ & & & & \\
\hline
\end{tabular}




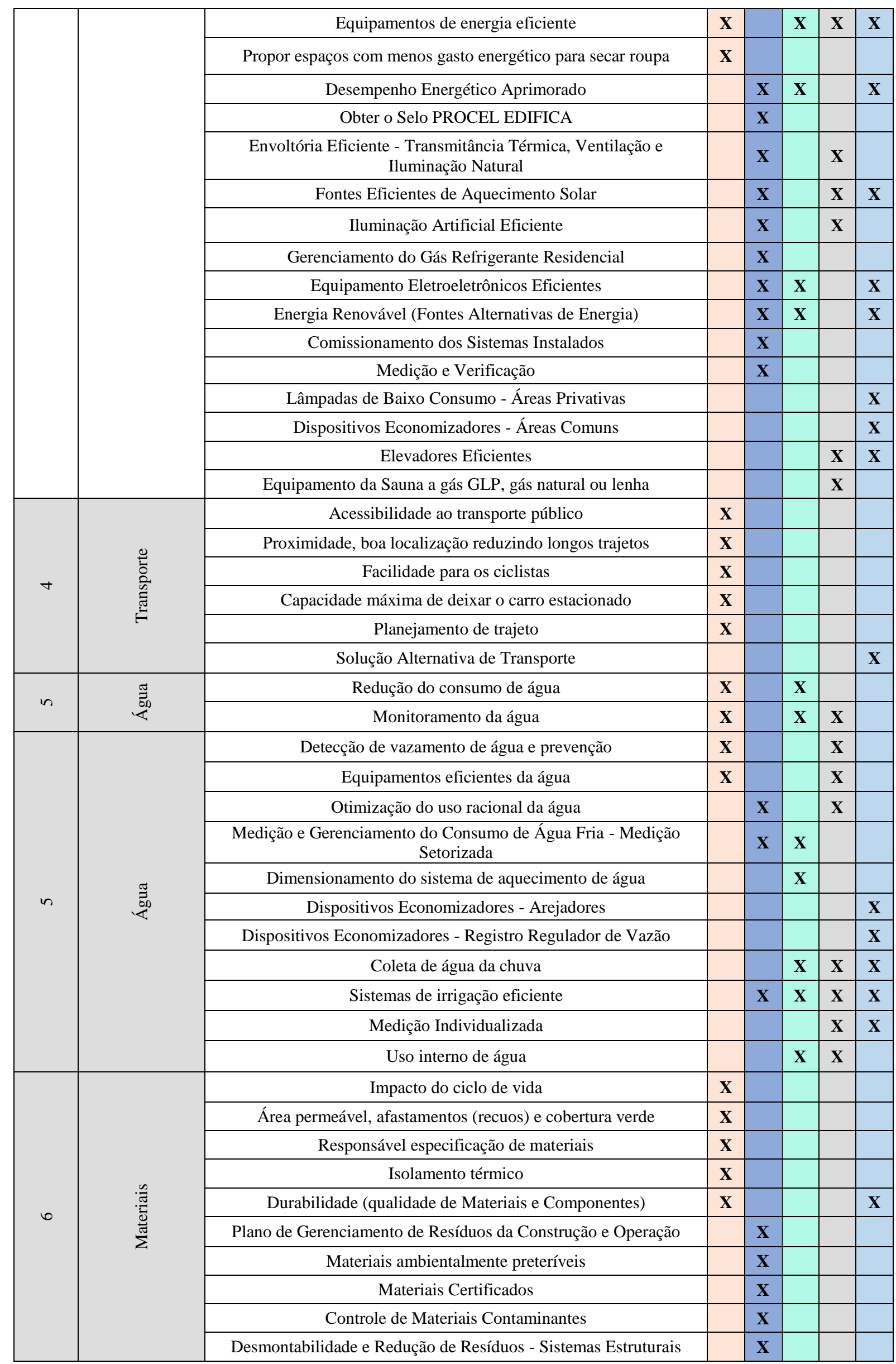




\begin{tabular}{|c|c|c|c|c|c|c|c|}
\hline & & $\begin{array}{l}\text { Desmontabilidade e Redução de Resíduos - Elementos Não } \\
\text { Estruturais }\end{array}$ & & $\mathbf{X}$ & & & \\
\hline & & Componentes Industrializados ou Pré-fabricados & & & & & $\mathbf{X}$ \\
\hline & & Formas e Escoras Reutilizáveis & & & & & $\mathbf{X}$ \\
\hline & & Concreto com Dosagem Otimizada & & & & & $\mathbf{X}$ \\
\hline & & Cimento de Alto-Forno (CP III) e Pozolânico (CP IV) & & & & & $\mathbf{X}$ \\
\hline & & Pavimentação com RCD (resíduos de construção e demolição) & & & & & $\mathbf{X}$ \\
\hline & & Facilidade de Manutenção da Fachada & & & & & $\mathbf{X}$ \\
\hline & & Madeira Plantada ou Certificada & & $\mathbf{X}$ & & & $\mathbf{X}$ \\
\hline \multirow{7}{*}{ r } & \multirow{7}{*}{ 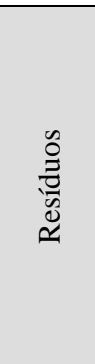 } & Gestão de Resíduos de Construção & $\mathbf{X}$ & & $\mathbf{X}$ & & $\mathbf{X}$ \\
\hline & & Gestão de Resíduos de Demolição & & & $\mathbf{X}$ & & $\mathbf{X}$ \\
\hline & & Agregados reciclados & $\mathbf{X}$ & & $\mathbf{X}$ & & \\
\hline & & Canteiro de obras com baixo impacto ambiental & & & $\mathbf{X}$ & & \\
\hline & & Resíduos operacionais & $\mathbf{X}$ & & $\mathbf{X}$ & & \\
\hline & & Pisos e forros aprovados pelo cliente & $\mathbf{X}$ & & & & $\mathbf{X}$ \\
\hline & & Coordenação Modular (modulação) & & & & & $\mathbf{X}$ \\
\hline \multirow{8}{*}{$\infty$} & \multirow{8}{*}{ 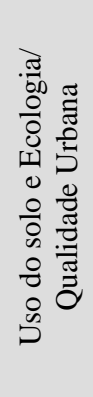 } & A escolha do local & $\mathbf{X}$ & & & & \\
\hline & & Valor ecológico do local e proteção dos recursos ecológicos & $\mathbf{X}$ & & & & \\
\hline & & Mitigar o impacto ecológico & $\mathbf{X}$ & & & & \\
\hline & & Melhorias na área local & $\mathbf{X}$ & & & & \\
\hline & & Impacto a longo prazo sobre a biodiversidade & $\mathbf{X}$ & & & & \\
\hline & & Qualidade do Entorno - Infraestrutura & & & & & $\mathbf{X}$ \\
\hline & & Qualidade do Entorno - Impactos & & & & & $\mathbf{X}$ \\
\hline & & Melhorias no Entorno & & & & & $\mathbf{X}$ \\
\hline \multirow{7}{*}{$\infty$} & \multirow{7}{*}{ 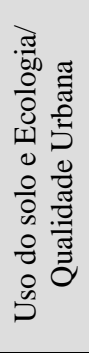 } & Recuperação de Áreas Degradadas & & & & & $\mathbf{X}$ \\
\hline & & Reabilitação de Imóveis & & & & & $\mathbf{X}$ \\
\hline & & Paisagismo & & & & & $\mathbf{X}$ \\
\hline & & Relação com a vizinhança & & & & & $\mathbf{X}$ \\
\hline & & Local para Coleta Seletiva & & & & & $\mathbf{X}$ \\
\hline & & Área permeável, afastamentos e cobertura verde & $\mathbf{X}$ & & & & $\mathbf{X}$ \\
\hline & & Infiltração de Águas Pluviais & & & & & $\mathbf{X}$ \\
\hline \multirow{5}{*}{ a } & \multirow{5}{*}{ 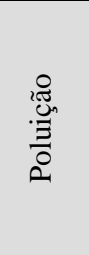 } & Impacto dos ar condicionados & $\mathbf{X}$ & & & $\mathbf{X}$ & \\
\hline & & Reduzida emissão de CO2 & $\mathbf{X}$ & & & & \\
\hline & & Água escoamento superficial & $\mathbf{X}$ & & & & \\
\hline & & Redução da poluição luminosa noturna (que perturbe os vizinhos) & $\mathbf{X}$ & & & & \\
\hline & & Atenuação de ruído & $\mathbf{X}$ & & & & \\
\hline \multirow{8}{*}{ 으 } & \multirow{8}{*}{$\begin{array}{l}\overline{0} \\
\mathbb{0} \\
0 \\
\vdots \\
0 \\
: 0 \\
0 \\
0 \\
0 \\
0 \\
0 \\
0 \\
0 \\
0 \\
0\end{array}$} & Projeto Integrado e Planejamento & & $\mathbf{X}$ & & & \\
\hline & & Gerenciamento da Qualidade visando a durabilidade & & $\mathbf{X}$ & & & \\
\hline & & Manual do Usuário & & $\mathbf{X}$ & & & \\
\hline & & Análise do ciclo de vida & & $\mathbf{X}$ & & & \\
\hline & & Inovação e Projeto & & $\mathbf{X}$ & & & \\
\hline & & Flexibilidade de Projeto & & & & & $\mathbf{X}$ \\
\hline & & Desempenho Térmico - Orientação ao Sol e Ventos & & & & & $\mathbf{X}$ \\
\hline & & Ventilação e Iluminação Natural de Banheiros & & & & & $\mathbf{X}$ \\
\hline \multirow{4}{*}{$=$} & \multirow{4}{*}{ 总 } & Prioridades Regionais - Norte & & $\mathbf{X}$ & & & \\
\hline & & Prioridades Regionais - Nordeste & & $\mathbf{X}$ & & & \\
\hline & & Prioridades Regionais - Sul & & $\mathbf{X}$ & & & \\
\hline & & Prioridades Regionais - Sudeste & & $\mathbf{X}$ & & & \\
\hline
\end{tabular}




\begin{tabular}{|c|c|c|c|c|c|c|}
\hline & & Prioridades Regionais - Centro-Oeste & $\mathbf{X}$ & & & \\
\hline \multirow{14}{*}{$\simeq$} & \multirow{14}{*}{ 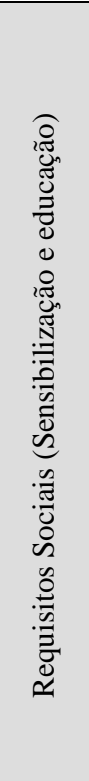 } & Capacitação Profissional dos Empregados & $\mathbf{X}$ & & & $\mathbf{X}$ \\
\hline & & Acessibilidade Universal & $\mathbf{X}$ & & & \\
\hline & & Boas Práticas Sociais para Projeto e Obra & $\mathbf{X}$ & & & \\
\hline & & Boas Práticas Sociais para Operação e Manutenção & $\mathbf{X}$ & $\mathbf{X}$ & & \\
\hline & & Informalidade Zero & & & & $\mathbf{X}$ \\
\hline & & Educação para a Gestão de RCD & & & & $\mathbf{X}$ \\
\hline & & Educação Ambiental dos Empregados & & & & $\mathbf{X}$ \\
\hline & & Desenvolvimento Pessoal dos Empregados & & & & $\mathbf{X}$ \\
\hline & & Inclusão de trabalhadores locais & & & & $\mathbf{X}$ \\
\hline & & Participação da Comunidade na Elaboração do Projeto & & & & $\mathbf{X}$ \\
\hline & & Orientação aos Moradores & & $\mathbf{X}$ & & $\mathbf{X}$ \\
\hline & & Educação Ambiental dos Moradores & & $\mathbf{X}$ & & $\mathbf{X}$ \\
\hline & & Ações para Mitigação de Riscos Sociais & & & & $\mathbf{X}$ \\
\hline & & Ações para a Geração de Empregos e Renda & & & & $\mathbf{X}$ \\
\hline \multirow{3}{*}{ 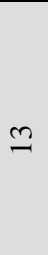 } & \multirow{3}{*}{ 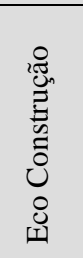 } & Relação do edifício com seu entorno & & $\mathbf{X}$ & & \\
\hline & & Escolha integrada de produtos, sistemas e processos construtivos & & $\mathbf{X}$ & & \\
\hline & & Canteiro de obras com baixo impacto ambiental & & $\mathbf{X}$ & & \\
\hline \multirow{4}{*}{$\Xi$} & \multirow{4}{*}{$\begin{array}{l}\stackrel{0}{0} \frac{0}{0} \\
\frac{0}{0} \\
\text { 式 }\end{array}$} & Desempenho Térmico - Vedações & & & & $\mathbf{X}$ \\
\hline & & $\begin{array}{l}\text { Transmitância térmica, capacidade térmica e absortância solar das } \\
\text { superfícies }\end{array}$ & & & $\mathbf{X}$ & $\mathbf{X}$ \\
\hline & & Ventilação Natural & & & $\mathbf{X}$ & \\
\hline & & Iluminação Natural & & & $\mathbf{X}$ & \\
\hline \multirow{5}{*}{ 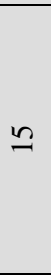 } & \multirow{5}{*}{ 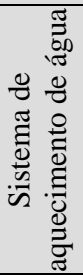 } & Sistema de aquecimento solar & & & $\mathbf{X}$ & \\
\hline & & Sistema de aquecimento à gás & & & $\mathbf{X}$ & $\mathbf{X}$ \\
\hline & & Bombas de calor & & & $\mathbf{X}$ & \\
\hline & & Sistema de aquecimento elétrico & & & $\mathbf{X}$ & \\
\hline & & Caldeiras a óleo & & & $\mathbf{X}$ & \\
\hline
\end{tabular}

Fonte: Segundo o site engenhariaearquitetura.com.br, visitado em 10 dez. 2014:

Ao questionarmos a viabilidade da certificação para uma residência unifamiliar, temos que ter em mente, em primeiro lugar, o que se pretende com a obtenção da certificação e que a obtenção de um certificado ou selo não se constitui no objeto do processo e que, na verdade, corresponde a um meio para quantificar e avaliar o desempenho ambiental de um determinado projeto, bem como monitorá-lo durante o uso. Ao projetar uma casa, seria básico exigir dos profissionais envolvidos que adotem soluções de projeto que permitam garantir que os ambientes de longa permanência apresentem pelo menos $80 \%$ das horas ao longo de um ano dentro da zona de conforto. Além disso, se considerarmos a quantidade de residências unifamiliares edificadas no Brasil, podemos apreender que o impacto ambiental e as emissões 
de gases de efeito estufa delas provenientes são significativos. Também o uso de recursos naturais, como água e energia, ao longo de sua vida útil, justifica a tomada de decisões de projeto ambientalmente responsáveis.

Outro ponto importante em relação à sustentabilidade é a questão da economia, a curto e longo prazo. É interessante observar que, na interação dos atributos e critérios das certificações e selos estudados, não foi abordado diretamente esta questão econômica, que adotada, utilizada e mantida corretamente, trará benefícios ao meio ambiente e ao próprio usuário. Sabe-se que, quando uma edificação recebe o selo sustentável, ela se encontra dentro dos parâmetros exigidos. Os projetos e as obras sustentáveis ainda são onerosos ao bolso dos usuários, porém, a partir de um determinado tempo, as despesas se pagam e a economia aparece. Com o uso da tabela de interação dos atributos, critérios e análise comparativa das Certificações Ambientais, chega-se ao exercício de avaliação das telhas.

\subsubsection{Critérios de Avaliação: Tipos de Telhas}

Tabela 4.3 Critérios de Avaliação -Tipos de Telhas.

\begin{tabular}{|c|c|c|c|c|c|c|c|}
\hline 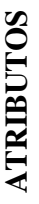 & $\begin{array}{l}\text { CRITÉRIOS DE } \\
\text { AVALIAÇÃO }\end{array}$ & $\sum_{\frac{1}{\infty}}^{\infty}$ & $\frac{9}{9}$ & $\underset{\wp}{\S}$ & 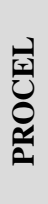 & 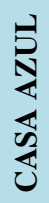 & OBJETIVOS \\
\hline \multirow{6}{*}{ 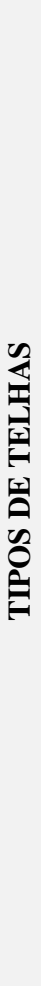 } & Compras sustentáveis & $X$ & & & & & $\begin{array}{l}\text { Para garantir a entrega de um produto funcional e sustentável, } \\
\text { projetado e construído de acordo com as expectativas de } \\
\text { desempenho. }\end{array}$ \\
\hline & $\begin{array}{l}\text { Práticas sustentáveis da } \\
\text { construção }\end{array}$ & $X$ & & & & & $\begin{array}{l}\text { Para reconhecer e incentivar a construção de locais geridos de } \\
\text { forma ambientalmente e socialmente responsável e confiável. }\end{array}$ \\
\hline & Transporte & $X$ & & & & & $\begin{array}{l}\text { Proximidade e boa localização, reduzindo longos trajetos. } \\
\text { Para incentivar e premiar um prédio que está localizado } \\
\text { próximo às amenidades locais, reduzindo assim a necessidade } \\
\text { de viagens longas ou múltiplas viagens. }\end{array}$ \\
\hline & Gestão de manutenção & & & $\mathrm{X}$ & & & $\begin{array}{l}\text { Facilidade de acesso para a execução da manutenção e } \\
\text { simplicidade das operações. Equipamento para a permanência } \\
\text { do desempenho na fase de uso. Informação destinada aos } \\
\text { futuros ocupantes e gestores. }\end{array}$ \\
\hline & $\begin{array}{l}\text { Canteiro de Obras com baixo } \\
\text { impacto ambiental }\end{array}$ & & & $X$ & & & $\begin{array}{l}\text { Disposições contractuais para obtenção de um canteiro de } \\
\text { obras com baixo impacto ambiental. Limitações dos } \\
\text { incômodos. Limitações dos riscos sanitários e de poluição } \\
\text { podendo afetar o terreno, os trabalhadores e a vizinhança. } \\
\text { Gestão dos resíduos do canteiro de obras. Controle dos } \\
\text { recursos de água e energia. Balanços do canteiro de obras. }\end{array}$ \\
\hline & Gestão de energia & $X$ & & $X$ & & & $\begin{array}{l}\text { Redução do consumo de energia por meio por meio da } \\
\text { concepção arquitetônica. Uso de energias renováveis locais. } \\
\text { Redução do consumo de energia para os sistemas de } \\
\text { condicionamento de ar, ventilação e exaustão. Redução do } \\
\text { consumo de energia para os sistemas de iluminação. Redução } \\
\text { do consumo de energia para os demais equipamentos. } \\
\text { Controle da eficiência energética. Desempenho do sistema } \\
\text { para produção de água quente. }\end{array}$ \\
\hline
\end{tabular}




\begin{tabular}{|c|c|c|c|c|c|}
\hline Gestão de manutenção & & & $\mathrm{X}$ & & $\begin{array}{l}\text { Facilidades de acesso para a execução da manutenção e } \\
\text { simplicidade das operações. Equipamentos para permanência } \\
\text { do desempenho na fase de uso. Informações destinadas aos } \\
\text { futuros ocupantes e gestores. }\end{array}$ \\
\hline Gestão de água & & & $\mathrm{X}$ & & $\begin{array}{l}\text { Redução do consumo de água potável. Gestão de águas } \\
\text { pluviais. Dimensionamento do sistema de aquecimento de } \\
\text { água. }\end{array}$ \\
\hline Retenção de águas pluviais & & & & $\mathrm{X}$ & $\begin{array}{l}\text { Permitir o escoamento de águas pluviais de modo controlado, } \\
\text { com vistas a prevenir o risco de inundações em regiões com } \\
\text { alta impermeabilização do solo e desonerar as redes públicas } \\
\text { de drenagem. }\end{array}$ \\
\hline Infiltração de águas pluviais & & & & $\mathrm{X}$ & $\begin{array}{l}\text { Permitir o escoamento de águas pluviais de modo controlado } \\
\text { ou favorecer a sua infiltração no solo, com vistas a prevenir o } \\
\text { risco de inundações, reduzir a poluição difusa, amenizar a } \\
\text { solicitação das redes públicas de drenagem e propiciar a } \\
\text { recarga do lençol freático. }\end{array}$ \\
\hline $\begin{array}{l}\text { Custo do ciclo de vida e } \\
\text { planejamento de vida útil. }\end{array}$ & $\mathrm{X}$ & & & & $\begin{array}{l}\text { Para reconhecer e incentivar o custo o ciclo de vida e } \\
\text { planejamento do serviço, a fim de melhorar a especificação do } \\
\text { projeto, através da manutenção e operação. }\end{array}$ \\
\hline Conforto térmico & $\mathrm{X}$ & & & & $\begin{array}{l}\text { Para assegurar-se de que os níveis apropriados do conforto } \\
\text { térmico estejam conseguidos com o projeto e os controles são } \\
\text { relacionados para manter um conforto térmico dos ocupantes } \\
\text { do edifício. }\end{array}$ \\
\hline Conforto higrotérmico & & & $\mathrm{X}$ & & $\begin{array}{l}\text { Implementação de medidas arquitetônicas para otimização } \\
\text { do conforto higrotérmico de verão e inverno. }\end{array}$ \\
\hline Isolamento térmico & $\mathrm{X}$ & & & & $\begin{array}{l}\text { Para reconhecer e incentivar o uso de isolamento térmico, que } \\
\text { tem uma relação de baixo impacto ambiental incorporado às } \\
\text { suas propriedades térmicas. }\end{array}$ \\
\hline Redução de resíduos & & $\mathrm{X}$ & & $\mathrm{X}$ & $\begin{array}{l}\text { Utilização de projetos modulares e sistemas desmontáveis } \\
\text { para minimizar os resíduos gerados pelos sistemas estruturais } \\
\text { na construção civil. Adoção de técnicas de projeto e } \\
\text { procedimentos para minimizar os resíduos gerados na } \\
\text { construção civil pelos elementos não estruturais. }\end{array}$ \\
\hline $\begin{array}{l}\text { Performance acústica } \\
\text { (Conforto acústico) }\end{array}$ & $\mathrm{X}$ & & & & $\begin{array}{l}\text { Para garantir o conforto acústico dos edifícios, incluindo } \\
\text { isolamento acústico e cumprimento das normas adequadas } \\
\text { para esta finalidade. }\end{array}$ \\
\hline Conforto ambiental interno & & $\mathrm{X}$ & & & $\begin{array}{l}\text { Estabelecer parâmetros de controle ambiental dentro das } \\
\text { residências, para as distintas estações do ano e regiões } \\
\text { brasileiras. }\end{array}$ \\
\hline Conforto visual & $\mathrm{X}$ & & $\mathrm{X}$ & & $\begin{array}{l}\text { Para garantir a iluminação natural e artificial e o controle dos } \\
\text { ocupantes. Para garantir o melhor desempenho visual e } \\
\text { conforto para os ocupantes do edifício. }\end{array}$ \\
\hline Acústica & & $\mathrm{X}$ & $\mathrm{X}$ & & $\begin{array}{l}\text { Reduzir a propagação de ruídos externos e o efeito prejudicial } \\
\text { que causam nos ambientes de maior permanência da } \\
\text { residência. }\end{array}$ \\
\hline $\begin{array}{l}\text { Controle de partículas } \\
\text { contaminantes }\end{array}$ & & $\mathrm{X}$ & & & $\begin{array}{l}\text { Reduzir a exposição dos ocupantes da residência e dos } \\
\text { trabalhadores da construção civil aos contaminantes do ar, por } \\
\text { meio do controle e da remoção de fontes de contaminação. }\end{array}$ \\
\hline Qualidade sanitária do ar & & & $\mathrm{X}$ & & $\begin{array}{l}\text { Ventilação eficiente. Controle das fontes de poluição interna. } \\
\text { Controle das fontes de poluição externa. }\end{array}$ \\
\hline Impacto do ciclo de vida & $\mathrm{X}$ & & & & $\begin{array}{l}\text { Para reconhecer e incentivar o uso de materiais de construção } \\
\text { com baixo impacto ambiental (incluindo carbono } \\
\text { incorporado) sobre o ciclo de vida do edifício. }\end{array}$ \\
\hline $\begin{array}{l}\text { Área permeável, afastamentos } \\
\text { (recuos) e cobertura } \\
\text { verde/Retenção de águas } \\
\text { pluviais. } \\
\end{array}$ & $\mathrm{X}$ & & & $\mathrm{X}$ & $\begin{array}{l}\text { Para reconhecer e incentivar a especificação de materiais para } \\
\text { a proteção de fronteira e externas superfícies duras que tem } \\
\text { um baixo impacto ambiental, tendo em conta o ciclo de vida } \\
\text { dos materiais utilizados. }\end{array}$ \\
\hline Materiais certificados & $\mathrm{X}$ & & & & $\begin{array}{l}\text { Para reconhecer e incentivar a especificação de materiais de } \\
\text { origem de forma responsável para os elementos chave de } \\
\text { construção. Estimular o uso de materiais que possuam algum } \\
\text { tipo de certificado brasileiro ou internacional. }\end{array}$ \\
\hline
\end{tabular}




\begin{tabular}{|c|c|c|c|c|c|c|}
\hline \multirow{11}{*}{ 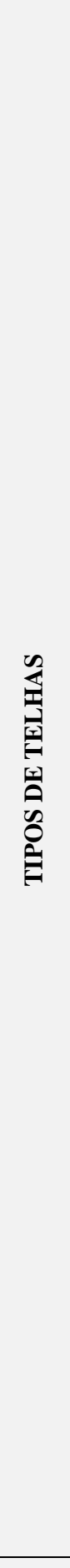 } & $\begin{array}{l}\text { Fontes eficientes de } \\
\text { aquecimento solar/ Sistema de } \\
\text { aquecimento solar }\end{array}$ & & $\mathrm{X}$ & & $\mathrm{X}$ & $\begin{array}{l}\text { Incentivar a adoção de fontes de energia renovável, } \\
\text { promovendo a redução do consumo de energia utilizada para } \\
\text { o aquecimento de água, por meio de utilização de Sistemas de } \\
\text { Aquecimento Solar (SAS), ou por meio de Sistemas de } \\
\text { Recuperação de Calor e reduzir as perdas térmicas relativas à áca } \\
\text { distribuição de água quente, diminuindo a carga energética } \\
\text { demandada pelos edifícios. Reduzir o consumo de energia } \\
\text { solar elétrica ou de gás para o aquecimento de água. }\end{array}$ \\
\hline & $\begin{array}{l}\text { Materiais ambientalmente } \\
\text { preferíveis }\end{array}$ & & $\mathrm{x}$ & & & $\begin{array}{l}\text { Utilizar materiais incorporados ou não à construção que sejam } \\
\text { regionais, provenientes de reuso, com conteúdo reciclado, de } \\
\text { rápida renovação e recicláveis, visando reduzir as emissões de } \\
\text { dióxido de carbono }\left(\mathrm{CO}_{2}\right) \text { e a extração de recursos naturais } \\
\text { não renováveis. }\end{array}$ \\
\hline & $\begin{array}{l}\text { Controle de materiais } \\
\text { contaminantes }\end{array}$ & & $\mathrm{X}$ & & & $\begin{array}{l}\text { Diminuir a produção de materiais com conteúdo } \\
\text { contaminantes e perigosos, com odor potencialmente irritante, } \\
\text { forte ou que possam causar lesão, desconforto ou mal estar aos } \\
\text { ocupantes, usuários, instaladores e operários da construção, } \\
\text { controlando seus níveis e índices, dentro de limites } \\
\text { estipulados pela legislação. }\end{array}$ \\
\hline & $\begin{array}{l}\text { Componentes industrializados } \\
\text { ou pré-fabricados }\end{array}$ & $\mathrm{X}$ & & & $\mathrm{X}$ & $\begin{array}{l}\text { Reduzir as perdas de materiais e a geração de resíduos, } \\
\text { colaborando para a redução do consumo de recursos naturais } \\
\text { pelo emprego de componentes industrializados. }\end{array}$ \\
\hline & Redução da emissão de CO2 & $X$ & & & & $\begin{array}{l}\text { Para reconhecer e incentivar edifícios projetados para } \\
\text { minimizar a energia operacional, consumo e emissões de } \\
\mathrm{CO} 2 \text {. }\end{array}$ \\
\hline & Monitoramento de energia & $X$ & & & & $\begin{array}{l}\text { Para reconhecer e incentivar a instalação de energia sub- } \\
\text { medição que facilita o monitoramento do consumo de energia } \\
\text { operacional. }\end{array}$ \\
\hline & $\begin{array}{l}\text { Desempenho energético } \\
\text { aprimorado }\end{array}$ & & $X$ & & & $\begin{array}{l}\text { Aprimorar o desempenho energético da residência, superando } \\
\text { o nível A estipulado pelo selo Procel EDIFICA. }\end{array}$ \\
\hline & $\begin{array}{l}\text { Baixo e zero emissões de } \\
\text { carbono }\end{array}$ & $\mathrm{X}$ & & & & $\begin{array}{l}\text { Para reduzir as emissões de carbono e poluição atmosférica, } \\
\text { incentivando a geração de energia local a partir de fontes } \\
\text { renováveis para abastecer uma proporção significativa da } \\
\text { demanda de energia. }\end{array}$ \\
\hline & Energia renovável & & $\mathrm{X}$ & & & $\begin{array}{l}\text { Incentivar a adoção de energias renováveis nas residências, de } \\
\text { forma a reduzir o consumo e o impacto ambiental associado } \\
\text { ao consumo de energia. }\end{array}$ \\
\hline & Obter o Procel EDIFICA & & $X$ & & & Receber a etiquetagem Procel EDIFICA nível A. \\
\hline & $\begin{array}{l}\text { Madeira plantada ou } \\
\text { certificada }\end{array}$ & & $\mathrm{X}$ & & $\mathrm{X}$ & $\begin{array}{l}\text { Incentivar a utilização da madeira certificada, por meio do } \\
\text { emprego de produtos provenientes de espécies nativas } \\
\text { devidamente legalizadas ou e espécies exóticas de rápido } \\
\text { crescimento (reflorestamento), e, consequentemente, } \\
\text { promover o manejo sustentável em toda a cadeia produtiva } \\
\text { madeireira. }\end{array}$ \\
\hline & $\begin{array}{l}\text { Gestão de resíduos de } \\
\text { construção }\end{array}$ & $\mathrm{X}$ & & $\mathrm{X}$ & $\mathrm{X}$ & $\begin{array}{l}\text { Reduzir a quantidade de resíduos de construção e seus } \\
\text { impactos no meio ambiente urbano e nas finanças municipais, } \\
\text { por meio da promoção ao respeito das diretrizes estabelecidas } \\
\text { nas Resoluções n. } 307 \text { e n. } 348 \text { do CONAMA (Brasil, } 2002 \text { e } \\
\text { 2004). }\end{array}$ \\
\hline 됫 & $\begin{array}{l}\text { Gestão de resíduos de } \\
\text { demolição }\end{array}$ & & & $\mathrm{X}$ & $\mathrm{X}$ & $\begin{array}{l}\text { Reduzir a quantidade de resíduos de demolição e seus } \\
\text { impactos no meio ambiente urbano e nas finanças municipais, } \\
\text { por meio da promoção ao respeito das diretrizes estabelecidas } \\
\text { nas Resoluções n. } 307 \text { e n. } 348 \text { do CONAMA (Brasil, } 2002 \text { e } \\
\text { 2004). }\end{array}$ \\
\hline
\end{tabular}




\begin{tabular}{|c|c|c|c|c|c|c|}
\hline & $\begin{array}{l}\text { Coordenação modular } \\
\text { (modulação) }\end{array}$ & & & & $\mathrm{X}$ & $\begin{array}{l}\text { Reduzir as perdas de materiais pela necessidade de cortes, } \\
\text { ajustes de componentes e uso de material de enchimento; } \\
\text { aumentar a produtividade da construção civil e reduzir o } \\
\text { volume de RCD (resíduos de construção e demolição). }\end{array}$ \\
\hline & Retenção de águas pluviais & $\mathrm{X}$ & & & & $\begin{array}{l}\text { Permite o escoamento das águas pluviais de modo controlado, } \\
\text { com vistas a prevenir o risco de inundações em regiões com } \\
\text { alta impermeabilização do solo e desonerar as redes públicas } \\
\text { de drenagem. }\end{array}$ \\
\hline & $\begin{array}{l}\text { Gerenciamento da qualidade, } \\
\text { visando à durabilidade. }\end{array}$ & & $\mathrm{X}$ & & & $\begin{array}{l}\text { Aumentar a durabilidade e o desempenho da envoltória da } \\
\text { residência, bem como de seus componentes e sistemas, por } \\
\text { meio de um projeto adequado, da seleção de materiais e de } \\
\text { práticas de construção convenientes. }\end{array}$ \\
\hline & $\begin{array}{l}\text { Qualidade de materiais e } \\
\text { componentes }\end{array}$ & & & & $\mathrm{X}$ & $\begin{array}{l}\text { Evitar o uso de produtos de baixa qualidade, reduzindo o consumo } \\
\text { de produtos naturais utilizados na correção e custos da correção de } \\
\text { defeitos, além de melhorar as condições de competitividade dos } \\
\text { fabricantes que operam em conformidade com a normatização. }\end{array}$ \\
\hline & Manual do usuário & & $X$ & & & $\begin{array}{l}\text { Desenvolver um guia que contenha informações sobre os } \\
\text { equipamentos e sistemas instalados e como operá-los, para } \\
\text { que a mesma mantenha seu desempenho elevado ao longo de } \\
\text { sua vida útil. }\end{array}$ \\
\hline & Análise de ciclo de vida & & $\mathrm{X}$ & & & $\begin{array}{l}\text { Prover a análise e comparação do ciclo de vida de um material } \\
\text { utilizado em obra, incentivando assim o uso de materiais que } \\
\text { causem menor impacto na sua produção durante seu ciclo de } \\
\text { vida. }\end{array}$ \\
\hline & $\begin{array}{l}\text { Boas práticas sociais para } \\
\text { projeto e obra }\end{array}$ & & $\mathrm{X}$ & & & $\begin{array}{l}\text { Incentivar o comprometimento empresarial com o bem-estar } \\
\text { e inclusão social dos colaboradores. Minimizar os resíduos } \\
\text { gerados em obra, promover a ampliação da capacidade } \\
\text { econômica dos moradores da área de intervenção e entorno, } \\
\text { considerando o período de construção e operãão. }\end{array}$ \\
\hline & $\begin{array}{l}\text { Boas práticas sociais para } \\
\text { operação e manutenção }\end{array}$ & & $X$ & $\mathrm{X}$ & & $\begin{array}{l}\text { Estimular o estudo do impacto de implantação da edificação } \\
\text { na comunidade local e produção de material visando manter o } \\
\text { uso de boas práticas durante a vida útil da mesma. Através da } \\
\text { educação, desenvolver e estimular a mudança de } \\
\text { comportamento efetiva dos moradores para uma operação e } \\
\text { manutenção mais sustentável do empreendimento. }\end{array}$ \\
\hline & $\begin{array}{l}\text { Impacto em longo prazo sobre } \\
\text { a biodiversidade }\end{array}$ & $\mathrm{X}$ & & & & $\begin{array}{l}\text { Para minimizar o impacto em longo prazo do } \\
\text { desenvolvimento no local e na biodiversidade da área } \\
\text { circunvizinha. }\end{array}$ \\
\hline & $\begin{array}{l}\text { Projeto integrado e } \\
\text { planejamento }\end{array}$ & & $\mathrm{X}$ & & & $\begin{array}{l}\text { Maximizar oportunidades para integração da edificação, custo } \\
\text { efetivo da adoção de projetos verde e estratégias de } \\
\text { construção. }\end{array}$ \\
\hline \multirow{6}{*}{ 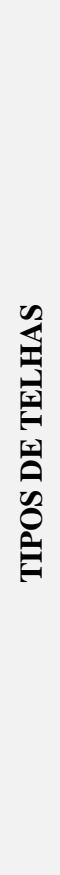 } & Informalidade zero & & & & $X$ & $\begin{array}{l}\text { A construção sustentável se inicia pelo processo de seleção de } \\
\text { fornecedores, somente empresas que operam exclusivamente } \\
\text { de maneira formal podem produzir e fornecer materiais de } \\
\text { forma compatível com o desenvolvimento sustentável. }\end{array}$ \\
\hline & Créditos regionais & & $\mathrm{X}$ & & & $\begin{array}{l}\text { Incentivar o desenvolvimento e criação de cadeias produtivas } \\
\text { referentes à construção civil, em diferentes regiões do país. }\end{array}$ \\
\hline & Inovação e projeto & & $\mathrm{X}$ & & & $\begin{array}{l}\text { Minimizar o impacto ambiental da residência por meio da } \\
\text { incorporação de técnicas sustentáveis e medidas construtivas } \\
\text { que tenham benefícios tangíveis e demonstráveis. }\end{array}$ \\
\hline & $\begin{array}{l}\text { Educação ambiental dos } \\
\text { empregados }\end{array}$ & & & & $\mathrm{X}$ & $\begin{array}{l}\text { Prestar informações e orientar os trabalhadores sobre a } \\
\text { utilização dos itens de sustentabilidade do empreendimento, } \\
\text { notadamente sobre os aspectos ambientais. }\end{array}$ \\
\hline & $\begin{array}{l}\text { Escolha integrada de produtos, } \\
\text { sistemas e processos } \\
\text { construtivos. }\end{array}$ & & & $\mathrm{X}$ & & $\begin{array}{l}\text { Escolha de produtos, sistemas e processos construtivos que } \\
\text { garantam a durabilidade da construção. Escolha de produtos, } \\
\text { sistemas e processos construtivos a fim de limitar os impactos } \\
\text { socioambientais do empreendimento e de sua construção. } \\
\text { Escolhas construtivas adaptadas à vida útil desejada da } \\
\text { construção. Escolhas construtivas considerando a facilidade } \\
\text { da conservação da construção. Escolha de fabricantes de } \\
\text { produtos que não pratiquem a informalidade na cadeia } \\
\text { produtiva. }\end{array}$ \\
\hline & Durabilidade & $\mathrm{X}$ & & & & $\begin{array}{l}\text { Para reconhecer e incentivar a proteção adequada dos } \\
\text { elementos expostos do edifício e da paisagem, minimizando } \\
\text { assim a frequência de substituição e maximizando a } \\
\text { otimização de materiais. }\end{array}$ \\
\hline
\end{tabular}




\begin{tabular}{|c|c|c|c|}
\hline Sistema de aquecimento solar & $\mathrm{X}$ & $\mathrm{X}$ & $\begin{array}{l}\text { Os coletores solares devem ser instalados com orientação e } \\
\text { ângulo de inclinação conforme especificações, manual de } \\
\text { instalações e projeto. }\end{array}$ \\
\hline Fontes alternativas de energia & & $\mathrm{X}$ & $\begin{array}{l}\text { Proporcionar menor consumo de energia por meio da geração } \\
\text { e conservação por fontes renováveis. }\end{array}$ \\
\hline $\begin{array}{l}\text { Transmitância térmica, } \\
\text { capacidade térmica e } \\
\text { absortância solar das } \\
\text { superfícies }\end{array}$ & $\mathrm{X}$ & $\mathrm{X}$ & $\begin{array}{l}\text { Devem ser atendidos de acordo com a zona bioclimática em } \\
\text { que a edificação se localiza. Obs.: Paredes referem-se a } \\
\text { elementos opacos, não incluem as aberturas e são usadas } \\
\text { principalmente no cálculo da transmitância térmica e } \\
\text { absorbtância (assim como as coberturas). Já as fachadas } \\
\text { referem-se a todos os elementos que compõem o fechamento } \\
\text { do edifício, incluindo elementos opacos e translúcidos. }\end{array}$ \\
\hline
\end{tabular}

\subsubsection{O Exercício de Avaliação e as Ponderações}

O critério utilizado para a execução do exercício será o mesmo adotado por Lannoy (2013) com as respectivas alterações necessárias para coberturas. Dos 189 critérios utilizados nas Certificações Ambientais estudadas neste trabalho (BREEAM, LEED, AQUA, CASA AZUL e PROCEL EDIFICA), os 43 critérios selecionados estão divididos em 4 atributos: Gestão de Projeto, Gestão de Obra, Produto e Material, Manutenção e Dimensões Sociais e Econômicas. Com os 43 critérios redistribuídos entre os 4 atributos, a análise e a pontuação terão maior organização e serão apresentadas de forma mais clara. Estes critérios têm pesos distribuídos entre 4 classes: indireta, direta, acessória e essencial, conforme Tabela 5.4.

Tabela 4.4 Quadro de Classes e Pontuação.

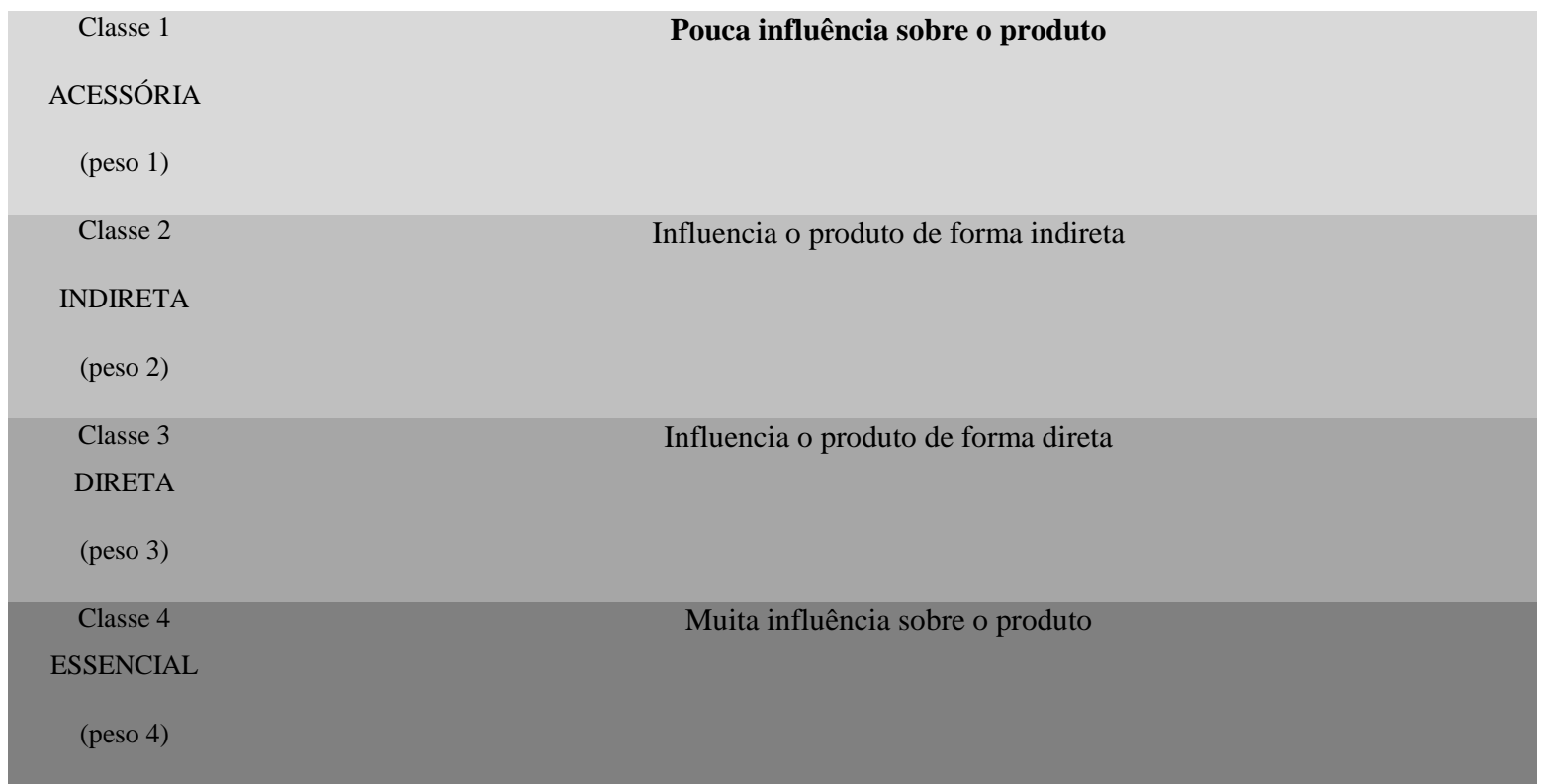

A Tabela 4.4 apresenta os 4 indicadores e os critérios escolhidos para a avaliação das telhas. 
Tabela 4.5 Método simplificado de avaliação de coberturas - tipos de telhas.

\begin{tabular}{|c|c|c|c|}
\hline ATRIBUTO & INDICADORES & CRITÉRIOS DE AVALIAÇÃO & TIPOS DE TELHA \\
\hline \multirow{37}{*}{$\frac{\mathscr{c}}{\frac{\alpha}{b}}$} & \multirow{10}{*}{ Gestão de Projetos } & $\begin{array}{l}\text { Custo do ciclo de vida e } \\
\text { planejamento de vida útil }\end{array}$ & 4 \\
\hline & & Projeto integrado e planejamento & 4 \\
\hline & & Inovação e projeto & 3 \\
\hline & & Impacto do ciclo de vida & 3 \\
\hline & & Materiais certificados & 4 \\
\hline & & Redução da emissão de $\mathrm{CO}^{2}$ & 3 \\
\hline & & Monitoramento de energia & 2 \\
\hline & & Energia renovável & 2 \\
\hline & & Créditos regionais & 2 \\
\hline & & $\begin{array}{l}\text { Gerenciamento da qualidade, visando } \\
\text { à durabilidade }\end{array}$ & 3 \\
\hline & \multirow{13}{*}{ Gestão de Obra } & Compras sustentáveis & 4 \\
\hline & & Práticas sustentáveis da construção & 2 \\
\hline & & Gestão de manutenção & 2 \\
\hline & & Transporte & 2 \\
\hline & & $\begin{array}{l}\text { Escolha integrada de produtos, } \\
\text { sistemas e processos construtivos }\end{array}$ & 3 \\
\hline & & Controle de partículas contaminantes & 2 \\
\hline & & Controle de materiais contaminantes & 4 \\
\hline & & $\begin{array}{c}\text { Canteiro de obras com baixo impacto } \\
\text { ambiental }\end{array}$ & 2 \\
\hline & & $\begin{array}{c}\text { Componentes industrializados ou } \\
\text { pré-fabricados }\end{array}$ & 4 \\
\hline & & Gestão de resíduos de construção & 2 \\
\hline & & Gestão de resíduos de demolição & 1 \\
\hline & & Coordenação modular / modulação & 2 \\
\hline & & Análise de ciclo de vida & 3 \\
\hline & \multirow{14}{*}{ Produto e Material } & Gestão de energia & 4 \\
\hline & & Gestão de água & 2 \\
\hline & & Retenção de águas pluviais & 2 \\
\hline & & Infiltração de águas pluviais & 1 \\
\hline & & Conforto térmico & 4 \\
\hline & & Conforto higrotérmico & 3 \\
\hline & & Isolamento térmico & 3 \\
\hline & & $\begin{array}{l}\text { Transmitância térmica, capacidade } \\
\text { térmica e absortância solar das } \\
\text { superfícies }\end{array}$ & 3 \\
\hline & & $\begin{array}{c}\text { Performance acústica (Conforto } \\
\text { acústico) }\end{array}$ & 3 \\
\hline & & Acústica & 3 \\
\hline & & Conforto ambiental interno & 4 \\
\hline & & Conforto visual & 2 \\
\hline & & Qualidade sanitária do ar & 1 \\
\hline & & $\begin{array}{l}\text { Fontes eficientes de aquecimento } \\
\text { solar/Sistema de aquecimento solar }\end{array}$ & 2 \\
\hline
\end{tabular}




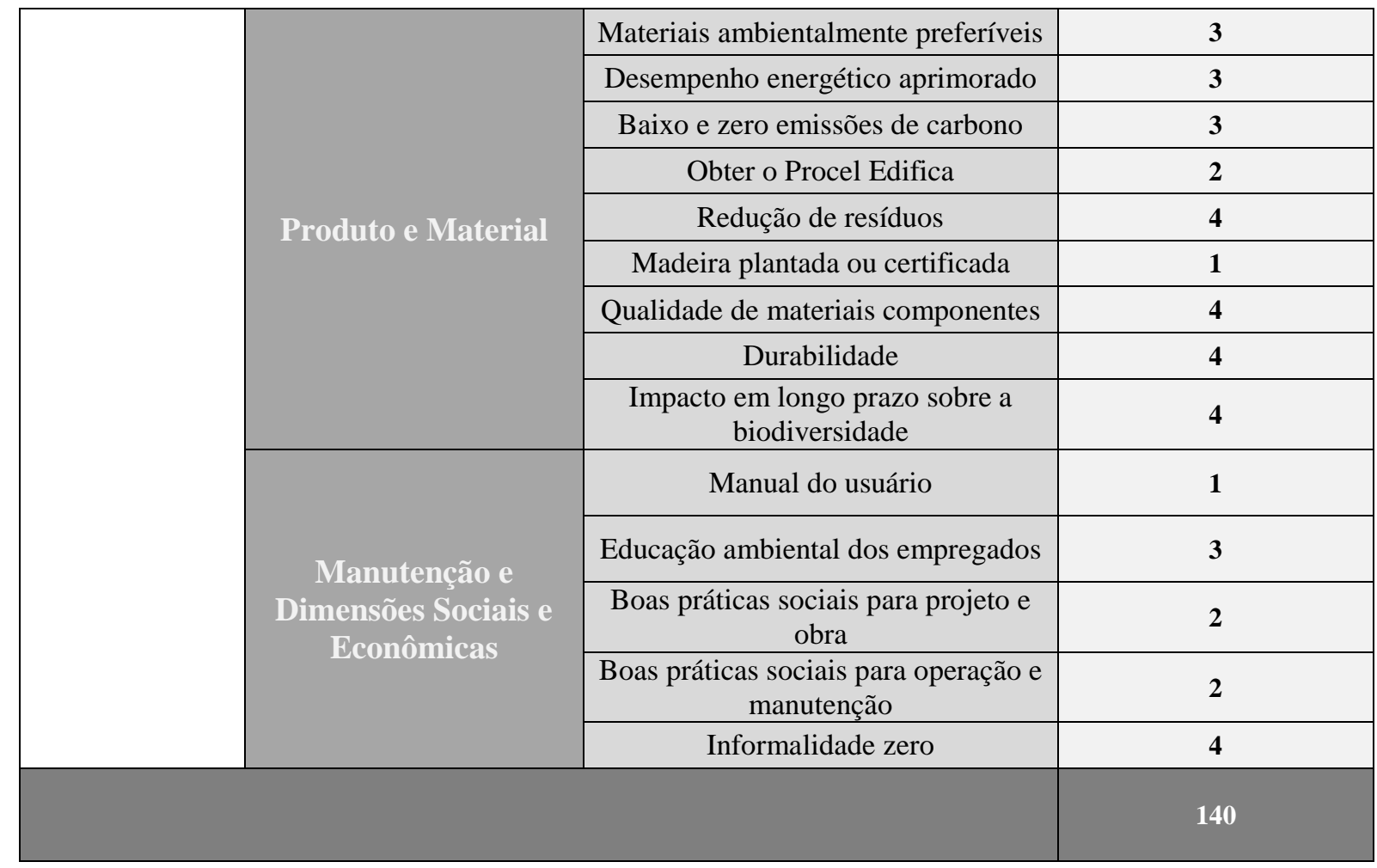

Na coluna dos Tipos de Telhas, a pontuação máxima para cada critério está classificada de acordo com o quadro de Classes, tendo o máximo de 140 pontos no total. A ponderação das classes se dá em relação aos níveis de influência sobre os produtos, conforme observado na Tabela 4.5.

Tabela 4.6 Classes das influências sobre o produto e pontuações.

\begin{tabular}{|c|c|c|}
\hline \multirow{6}{*}{$\begin{array}{c}\text { Classe } 1 \\
\text { ACESSÓRIA } \\
\quad(\text { peso 1) }\end{array}$} & Gestão de Projetos & --- \\
\hline & Gestão de Obra & Gestão de resíduos de demolição \\
\hline & \multirow{3}{*}{ Produto e Material } & Infiltração de águas pluviais \\
\hline & & Qualidade sanitária do ar \\
\hline & & Madeira plantada ou certificada \\
\hline & $\begin{array}{l}\text { Manutenção e Dimensões } \\
\text { Sociais e Econômicas }\end{array}$ & Manual do usuário \\
\hline \multirow{9}{*}{$\begin{array}{c}\text { Classe } 2 \\
\text { INDIRETA } \\
(\text { peso 2) }\end{array}$} & \multirow{3}{*}{ Gestão de Projetos } & Monitoramento de energia \\
\hline & & Energia renovável \\
\hline & & Créditos regionais \\
\hline & \multirow{6}{*}{ Gestão de Obra } & Práticas sustentáveis da construção \\
\hline & & Gestão de manutenção \\
\hline & & Transporte \\
\hline & & Controle de partículas contaminantes \\
\hline & & Canteiro de obras com baixo impacto ambiental \\
\hline & & Gestão de resíduos da construção \\
\hline
\end{tabular}




\begin{tabular}{|c|c|c|}
\hline & & Coordenação modular / modulação \\
\hline & \multirow{5}{*}{ Produto e Material } & Gestão da água \\
\hline & & Retenção de águas pluviais \\
\hline & & Conforto visual \\
\hline & & $\begin{array}{l}\text { Fontes eficientes de aquecimento solar/Sistema de } \\
\text { aquecimento solar }\end{array}$ \\
\hline & & Obter Procel Edifica \\
\hline & \multirow{2}{*}{$\begin{array}{l}\text { Manutenção e Dimensões } \\
\text { Sociais e Econômicas }\end{array}$} & Boas práticas sociais para projeto e obra \\
\hline & & Boas práticas sociais para operação e manutenção \\
\hline \multirow{15}{*}{$\begin{array}{c}\text { Classe } 3 \\
\text { DIRETA } \\
\text { (peso 3) }\end{array}$} & \multirow{4}{*}{ Gestão de Projetos } & Inovação e projeto \\
\hline & & Impacto do ciclo de vida \\
\hline & & Redução de emissão de $\mathrm{CO}^{2}$ \\
\hline & & Gerenciamento da qualidade, visando à durabilidade \\
\hline & \multirow{2}{*}{ Gestão de Obra } & $\begin{array}{l}\text { Escolha integrada de produtos, sistemas e processos } \\
\text { construtivos }\end{array}$ \\
\hline & & Análise de ciclo de vida \\
\hline & \multirow{8}{*}{ Produto e Material } & Conforto higrotérmico \\
\hline & & Isolamento térmico \\
\hline & & $\begin{array}{l}\text { Transmitância térmica, capacidade e absortância solar das } \\
\text { superfícies }\end{array}$ \\
\hline & & Performance acústica (conforto acústico) \\
\hline & & Acústica \\
\hline & & Materiais ambientalmente preferíveis \\
\hline & & Desempenho energético aprimorado \\
\hline & & Baixo e zero emissões de carbono \\
\hline & $\begin{array}{l}\text { Manutenção e Dimensões } \\
\text { Sociais e Econômicas }\end{array}$ & Educação ambiental dos empregados \\
\hline \multirow{13}{*}{$\begin{array}{c}\text { Classe } 4 \\
\text { ESSENCIAL } \\
\quad(\text { peso 4) }\end{array}$} & \multirow{3}{*}{ Gestão de Projetos } & Custo do ciclo de vida e planejamento de vida útil \\
\hline & & Projeto integrado e planejado \\
\hline & & Materiais certificados \\
\hline & \multirow{3}{*}{ Gestão de Obra } & Compras sustentáveis \\
\hline & & Controle de materiais contaminantes \\
\hline & & Componentes industrializados ou pré-fabricados \\
\hline & \multirow{7}{*}{ Produto e Material } & Gestão de energia \\
\hline & & Conforto térmico \\
\hline & & Conforto ambiental interno \\
\hline & & Redução de resíduos \\
\hline & & Qualidade de materiais componentes \\
\hline & & Durabilidade \\
\hline & & Impacto em longo prazo sobre a biodiversidade \\
\hline
\end{tabular}




\section{Manutenção e Dimensões}

Sociais e Econômicas

Ainda será utilizada a sigla n/a quando não houver aplicação no produto, o que dependerá do material escolhido e de suas funções.

Para facilitar a conclusão após o levantamento e pontuação, as notas dos produtos serão distribuídas em letras como mostra o quadro de avaliação da Tabela 4.7 a seguir.

Tabela 4.7 Quadro de avaliação.

\begin{tabular}{|c|c|c|c|c|c|c|c|c|c|}
\hline \multicolumn{2}{|c|}{ E } & \multicolumn{2}{c|}{ D } & \multicolumn{2}{c|}{ C } & \multicolumn{2}{c|}{ B } & \multicolumn{2}{c|}{ A } \\
\hline 1 & 28 & 29 & 56 & 57 & 84 & 85 & 112 & 113 & 140 \\
\hline
\end{tabular}

Tendo a classificação "E” para pontuação de 1 a 28, "D" para pontuação de 29 a 56, "C" para pontuação de 57 a 84, "B” para pontuação de 85 a 112 e “A” para pontuação de 113 a 140.

\subsection{A aplicação dos produtos no método de avaliação da sustentabilidade}

Apesar de ainda ser objeto de debate recente no Brasil, a questão da qualidade e do desempenho das edificações habitacionais é de suma importância e está se consolidando ao longo dos anos. Para tanto, está sendo utilizada a norma de desempenho para edificações habitacionais NBR 15575 (ABNT, 2013), a qual apresenta critérios de desempenho para: habitabilidade (conforto visual, conforto acústico, conforto higrotérmico, acessibilidade, funcionalidade, salubridade, estanqueidade, conforto tátil e ergonomia); sustentabilidade (durabilidade, manutenibilidade e desempenho ambiental) e segurança (estrutural, ao fogo e no uso).

No caso das coberturas sustentáveis, foram levantados sete tipos de telhas usadas no mercado da construção civil e que fazem parte deste trabalho. Como base de análise, as seguintes telhas foram avaliadas: fotovoltaicas, tetra pak, vegetais, cerâmicas, translúcidas PET, fibrocimento e concreto. 


\section{CAPÍtULO 5}

\section{APLICAÇÃO, ANÁLISES E RESULTADOS}

Este capítulo é referente às análises das telhas apresentadas. Os resultados são obtidos através da aplicação nos 7 produtos escolhidos, de 6 empresas diferentes e tendo alguns objetivos finais distintos. A comparação e estudo são dados com intuito de avaliação sustentável e pontuação no término das análises, utilizando o método de avaliação sustentável através dos Selos Ecológicos citados no capítulo 3.

Foram consideradas todas as informações obtidas sobre cada produto disponibilizadas pela empresa em seu site na internet, em catálogos, documentos enviados e contatos diretos com a empresa.

Ressalta-se que, foram solicitadas as empresas estudadas, comprovações dos dados sustentáveis e laudos técnicos de seus produtos, porém não houve resposta de algumas delas e, desta forma, a análise foi realizada a partir dos dados fornecidos pelas páginas da empresa online e outras fontes de pesquisa como trabalhos já realizados e sites de lojas online.

Segue-se a apresentação do método de avaliação sustentável com as pontuações alcançadas na Tabela 5.1.

Tabela 5.1 Resultados do método de avaliação sustentável em sistemas de coberturas.

\begin{tabular}{|c|c|c|c|c|c|c|c|c|c|}
\hline 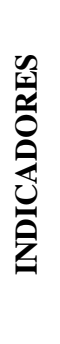 & $\begin{array}{l}\text { CRITÉRIOS } \\
\text { DE } \\
\text { AVALIAÇÃO }\end{array}$ & 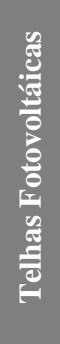 & 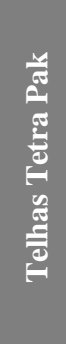 & 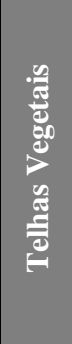 & 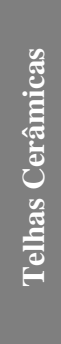 & 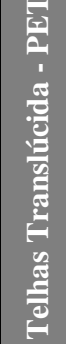 & 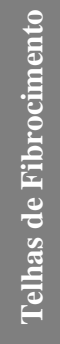 & 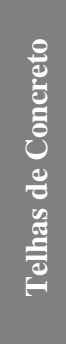 & OBJETIVOS \\
\hline \multirow{2}{*}{ 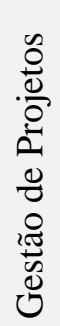 } & $\begin{array}{l}\text { Custo do ciclo } \\
\text { de vida e } \\
\text { planejamento de } \\
\text { vida útil }\end{array}$ & 3 & 3 & 3 & 2 & 3 & 1 & 3 & $\begin{array}{l}\text { Para reconhecer e incentivar o custo, o } \\
\text { ciclo de vida e planejamento do serviço, a } \\
\text { fim de melhorar a especificação do projeto, } \\
\text { através da manutenção e operação. }\end{array}$ \\
\hline & $\begin{array}{c}\text { Projeto } \\
\text { integrado e } \\
\text { planejamento }\end{array}$ & 2 & 3 & 3 & 2 & 3 & 1 & 2 & $\begin{array}{l}\text { Minimizar oportunidades para integração } \\
\text { da edificação, custo efetivo da adoção de } \\
\text { projetos verdes e estratégias de construção. }\end{array}$ \\
\hline
\end{tabular}




\begin{tabular}{|c|c|c|c|c|c|c|c|c|c|}
\hline & $\begin{array}{l}\text { CRITÉRIOS } \\
\text { DE } \\
\text { AVALIAÇÃO }\end{array}$ & 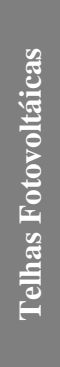 & 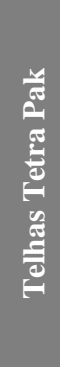 & 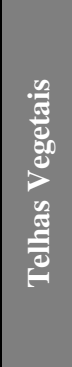 & 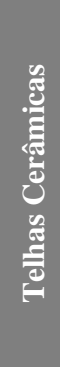 & 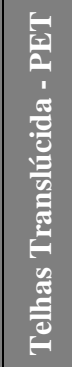 & 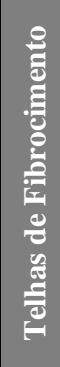 & 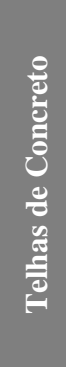 & OBJETIVOS \\
\hline & $\begin{array}{l}\text { Inovação e } \\
\text { projeto }\end{array}$ & 3 & 4 & 4 & 2 & 4 & 1 & 3 & $\begin{array}{l}\text { Minimizar o impacto ambiental da } \\
\text { residência por meio da incorporação de } \\
\text { técnicas sustentáveis e medidas } \\
\text { construtivas que tenham benefícios } \\
\text { tangíveis e demonstráveis. }\end{array}$ \\
\hline & $\begin{array}{c}\text { Impacto do ciclo } \\
\text { de vida }\end{array}$ & 2 & 4 & 4 & 2 & 3 & 1 & 3 & $\begin{array}{l}\text { Para reconhecer e incentivar o uso de } \\
\text { materiais de construção com baixo impacto } \\
\text { ambiental (incluindo carbono incorporado) } \\
\text { sobre o ciclo de vida do edifício. }\end{array}$ \\
\hline & $\begin{array}{l}\text { Materiais } \\
\text { certificados }\end{array}$ & 3 & 3 & 4 & 2 & 3 & 1 & 4 & $\begin{array}{l}\text { Para reconhecer e incentivar a } \\
\text { especificação de materiais de origem de } \\
\text { forma responsável para os elementos chave } \\
\text { de construção. Estimular o uso de materiais } \\
\text { que possuam algum tipo de certificado } \\
\text { brasileiro ou internacional. }\end{array}$ \\
\hline & $\begin{array}{c}\text { Redução da } \\
\text { emissão de } \mathrm{CO}^{2}\end{array}$ & 2 & 2 & 2 & 2 & 2 & 1 & 2 & $\begin{array}{l}\text { Para reconhecer e incentivar edifícios } \\
\text { projetados para minimizar a energia } \\
\text { operacional, consumo e emissões de } \mathrm{CO} 2 \text {. }\end{array}$ \\
\hline & $\begin{array}{l}\text { Monitoramento } \\
\text { de energia }\end{array}$ & 3 & 2 & 2 & 2 & 3 & 1 & 2 & $\begin{array}{l}\text { Para reconhecer e incentivar a instalação de } \\
\text { energia sub-medição que facilita o } \\
\text { monitoramento do consumo de energia } \\
\text { operacional. }\end{array}$ \\
\hline & $\begin{array}{l}\text { Energia } \\
\text { renovável }\end{array}$ & 4 & 2 & 2 & 1 & 2 & 1 & 2 & $\begin{array}{l}\text { Incentivar a adoção de energias renováveis } \\
\text { nas residências, de forma a reduzir o } \\
\text { consumo e o impacto ambiental associado } \\
\text { ao consumo de energia. }\end{array}$ \\
\hline & $\begin{array}{l}\text { Créditos } \\
\text { regionais }\end{array}$ & 2 & 3 & 3 & 2 & 2 & 1 & 3 & $\begin{array}{l}\text { Incentivar o desenvolvimento e criação de } \\
\text { cadeias produtivas referentes à construção } \\
\text { civil, em diferentes regiões do país. }\end{array}$ \\
\hline & $\begin{array}{l}\text { Gerenciamento } \\
\text { da qualidade, } \\
\text { visando à } \\
\text { durabilidade }\end{array}$ & 2 & 3 & 3 & 2 & 2 & 1 & 3 & $\begin{array}{l}\text { Aumentar a durabilidade e o desempenho } \\
\text { da envoltória da residência, bem como de } \\
\text { seus componentes e sistemas, por meio de } \\
\text { um projeto adequado, da seleção de } \\
\text { materiais e de práticas de construção } \\
\text { convenientes. }\end{array}$ \\
\hline 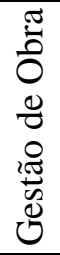 & $\begin{array}{c}\text { Compras } \\
\text { sustentáveis }\end{array}$ & 3 & 4 & 4 & 2 & 4 & 1 & 3 & $\begin{array}{l}\text { Para garantir a entrega de um produto } \\
\text { funcional e sustentável, projetado e } \\
\text { construído de acordo com as expectativas } \\
\text { de desempenho. }\end{array}$ \\
\hline
\end{tabular}




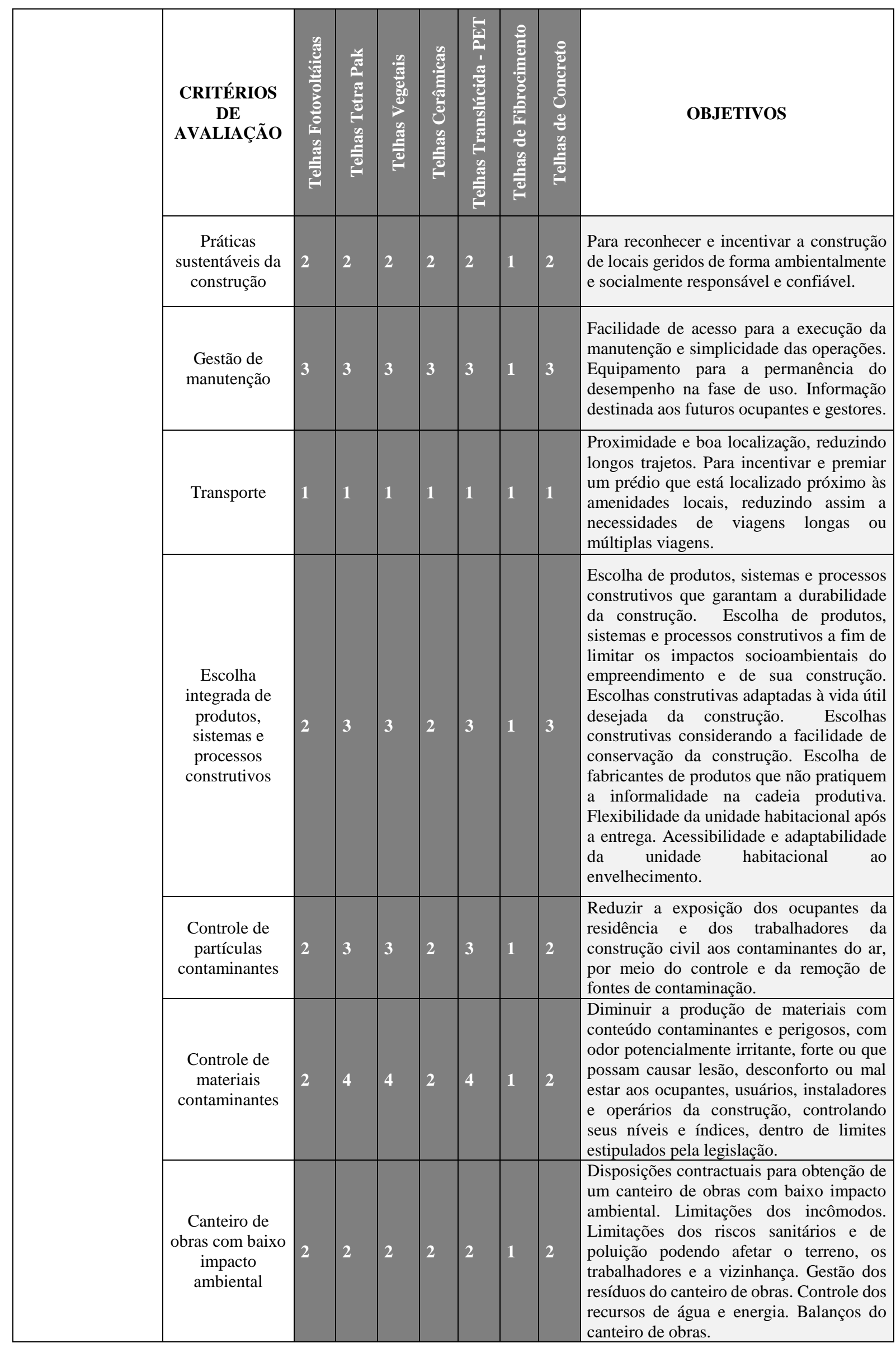




\begin{tabular}{|c|c|c|c|c|c|c|c|c|c|}
\hline & $\begin{array}{l}\text { CRITÉRIOS } \\
\text { DE } \\
\text { AVALIAÇÃO }\end{array}$ & 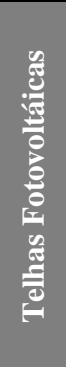 & 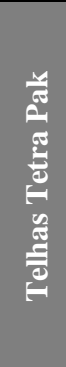 & 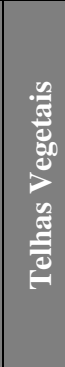 & 音 & & 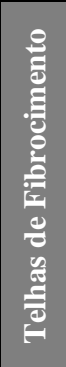 & 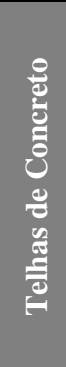 & OBJETIVOS \\
\hline & $\begin{array}{l}\text { Componentes } \\
\text { industrializados } \\
\text { ou pré- } \\
\text { fabricados }\end{array}$ & 3 & 3 & 4 & 2 & 3 & 1 & 3 & $\begin{array}{l}\text { Reduzir as perdas de materiais e a geração } \\
\text { de resíduos, colaborando para a redução do } \\
\text { consumo de recursos naturais pelo } \\
\text { emprego de componentes industrializados. }\end{array}$ \\
\hline & $\begin{array}{l}\text { Gestão de } \\
\text { resíduos de } \\
\text { construção }\end{array}$ & 2 & 3 & 3 & 2 & 3 & 1 & 2 & $\begin{array}{l}\text { Reduzir a quantidade de resíduos de } \\
\text { construção e seus impactos no meio } \\
\text { ambiente urbano e nas finanças } \\
\text { municipais, por meio da promoção ao } \\
\text { respeito das diretrizes estabelecidas nas } \\
\text { Resoluções n. } 307 \text { e n. } 348 \text { do CONAMA } \\
\text { (Brasil, } 2002 \text { e 2004). }\end{array}$ \\
\hline & $\begin{array}{l}\text { Gestão de } \\
\text { resíduos de } \\
\text { demolição }\end{array}$ & 2 & 3 & 3 & 2 & 3 & 1 & 2 & $\begin{array}{l}\text { Reduzir a quantidade de resíduos de } \\
\text { demolição e seus impactos no meio } \\
\text { ambiente urbano e nas finanças } \\
\text { municipais, por meio da promoção ao } \\
\text { respeito das diretrizes estabelecidas nas } \\
\text { Resoluções n. } 307 \text { e n. } 348 \text { do CONAMA } \\
\text { (Brasil, } 2002 \text { e 2004). }\end{array}$ \\
\hline & $\begin{array}{l}\text { Coordenação } \\
\text { modular / } \\
\text { modulação }\end{array}$ & 3 & 3 & 3 & 2 & 3 & 1 & 3 & $\begin{array}{l}\text { Reduzir as perdas de materiais pela } \\
\text { necessidade de cortes, ajustes de } \\
\text { componentes e uso de material de } \\
\text { enchimento; aumentar a produtividade da } \\
\text { construção civil e reduzir o volume de } \\
\text { RCD (resíduos de construção e } \\
\text { demolição). }\end{array}$ \\
\hline & $\begin{array}{l}\text { Análise de } \\
\text { ciclo de vida }\end{array}$ & 3 & 4 & 4 & 3 & 4 & 1 & 3 & $\begin{array}{l}\text { Prover a análise e comparação do ciclo de } \\
\text { vida de um material utilizado em obra, } \\
\text { incentivando assim o uso de materiais que } \\
\text { causem menor impacto na sua produção } \\
\text { durante seu ciclo de vida. }\end{array}$ \\
\hline \multirow[t]{2}{*}{ 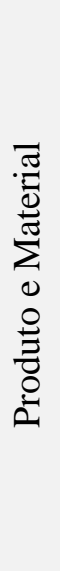 } & $\begin{array}{l}\text { Gestão de } \\
\text { energia }\end{array}$ & 4 & 2 & 2 & 1 & 2 & 1 & 2 & $\begin{array}{l}\text { Redução do consumo de energia por meio } \\
\text { da concepção arquitetônica. Uso de } \\
\text { energias renováveis locais. Redução do } \\
\text { consumo de energia para os sistemas de } \\
\text { condicionamento de ar, ventilação e } \\
\text { exaustão. Redução do consumo de energia } \\
\text { para os sistemas de iluminação. Redução } \\
\text { do consumo de energia para os demais } \\
\text { equipamentos. Controle da eficiência } \\
\text { energética. Desempenho do sistema para } \\
\text { produção de água quente. }\end{array}$ \\
\hline & Gestão de água & $\mathbf{n} / \mathbf{a}$ & $\mathbf{n} / \mathbf{a}$ & $\mathrm{n} / \mathrm{a}$ & $\mathrm{n} / \mathrm{a}$ & $\mathbf{n} / \mathbf{a}$ & $\mathbf{n} / \mathbf{a}$ & 1 & $\begin{array}{l}\text { Redução do consumo de água potável. } \\
\text { Gestão de águas } \\
\begin{array}{l}\text { Dimensionamento do pluviais. } \\
\text { aquecimento de água. }\end{array}\end{array}$ \\
\hline
\end{tabular}




\begin{tabular}{|c|c|c|c|c|c|c|c|c|}
\hline $\begin{array}{l}\text { CRITÉRIOS } \\
\text { DE } \\
\text { AVALIAÇÃo }\end{array}$ & 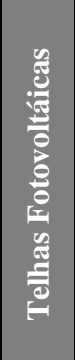 & 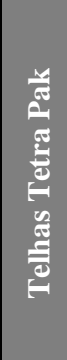 & 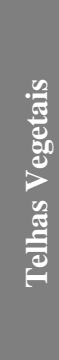 & 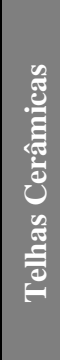 & 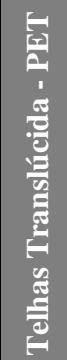 & 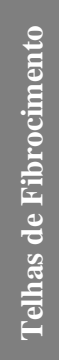 & 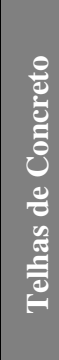 & OBJETIVOS \\
\hline $\begin{array}{l}\text { Retenção de } \\
\text { águas pluviais }\end{array}$ & $\mathrm{n} / \mathrm{a}$ & $\mathrm{n} / \mathrm{a}$ & $\mathrm{n} / \mathrm{a}$ & $\mathrm{n} / \mathrm{a}$ & $\mathrm{n} / \mathrm{a}$ & $\mathbf{n} / \mathbf{a}$ & 1 & $\begin{array}{l}\text { Permitir o escoamento de águas pluviais de } \\
\text { modo controlado, com vistas a prevenir o } \\
\text { risco de inundações em regiões com alta } \\
\text { impermeabilização do solo e desonerar as } \\
\text { redes públicas de drenagem. }\end{array}$ \\
\hline $\begin{array}{l}\text { Infiltração de } \\
\text { águas pluviais }\end{array}$ & $\mathbf{n} / \mathbf{a}$ & n/a & $\mathrm{n} / \mathrm{a}$ & $\mathrm{n} / \mathrm{a}$ & n/a & $\mathbf{n} / \mathbf{a}$ & 1 & $\begin{array}{l}\text { Permitir o escoamento de águas pluviais de } \\
\text { modo controlado ou favorecer a sua } \\
\text { infiltração no solo, com vistas a prevenir o } \\
\text { risco de inundações, reduzir a poluição } \\
\text { difusa, amenizar a solicitação das redes } \\
\text { públicas de drenagem e propiciar a recarga } \\
\text { do lençol freático. }\end{array}$ \\
\hline $\begin{array}{l}\text { Conforto } \\
\text { térmico }\end{array}$ & 2 & 2 & 3 & 2 & 2 & $\mathbf{n} / \mathbf{a}$ & 3 & $\begin{array}{l}\text { Para assegurar-se de que os níveis } \\
\text { apropriados do conforto térmico estejam } \\
\text { conseguidos com o projeto e os controles } \\
\text { são relacionados para manter um conforto } \\
\text { térmico dos ocupantes do edifício. }\end{array}$ \\
\hline $\begin{array}{c}\text { Conforto } \\
\text { higrotérmico }\end{array}$ & 3 & 2 & 3 & 2 & 1 & 1 & 3 & $\begin{array}{l}\text { Implementação de medidas arquitetônicas } \\
\text { para otimização do conforto higrotérmico } \\
\text { de verão e inverno. }\end{array}$ \\
\hline $\begin{array}{l}\text { Isolamento } \\
\text { térmico }\end{array}$ & 2 & 2 & 2 & 2 & 1 & $\mathbf{n} / \mathbf{a}$ & 2 & $\begin{array}{l}\text { Para reconhecer e incentivar o uso de } \\
\text { isolamento térmico, que tem uma relação } \\
\text { de baixo impacto ambiental incorporado às } \\
\text { suas propriedades térmicas. }\end{array}$ \\
\hline $\begin{array}{l}\text { Transmitância } \\
\text { térmica, } \\
\text { capacidade } \\
\text { térmica e } \\
\text { absortância } \\
\text { solar das } \\
\text { superfícies }\end{array}$ & 3 & 2 & 2 & 1 & 1 & $\mathbf{n} / \mathbf{a}$ & 2 & $\begin{array}{l}\text { Devem ser atendidos de acordo com a zona } \\
\text { bioclimática em que a edificação se } \\
\text { localiza. Obs.: Paredes referem-se a } \\
\text { elementos opacos, não incluem as } \\
\text { aberturas e são usadas principalmente no } \\
\text { cálculo da trasmitância térmica e } \\
\text { absortância (assim como as coberturas). Já } \\
\text { as fachadas referem-se a todos os } \\
\text { elementos que compõem o fechamento do } \\
\text { edifício, incluindo elementos opacos e } \\
\text { translúcidos. }\end{array}$ \\
\hline $\begin{array}{l}\text { Performance } \\
\text { acústica } \\
\text { (Conforto } \\
\text { acústico) }\end{array}$ & 1 & 1 & 1 & 1 & 1 & $\mathbf{n} / \mathbf{a}$ & 1 & $\begin{array}{l}\text { Para garantir o conforto acústico dos } \\
\text { edifícios, incluindo isolamento acústico e } \\
\text { cumprimento das normas adequadas para } \\
\text { esta finalidade. }\end{array}$ \\
\hline Acústica & 2 & 1 & 2 & 2 & 2 & $\mathbf{n} / \mathbf{a}$ & 2 & $\begin{array}{l}\text { Reduzir a propagação de ruídos externos e } \\
\text { o efeito prejudicial que causam nos } \\
\text { ambientes de maior permanência da } \\
\text { residência. }\end{array}$ \\
\hline $\begin{array}{l}\text { Conforto } \\
\text { ambiental } \\
\text { interno }\end{array}$ & 2 & 2 & 3 & 2 & 2 & $\mathrm{n} / \mathbf{a}$ & 3 & $\begin{array}{l}\text { Estabelecer parâmetros de controle } \\
\text { ambiental dentro das residências, para as } \\
\text { distintas estações do ano e regiôes } \\
\text { brasileiras. }\end{array}$ \\
\hline
\end{tabular}




\begin{tabular}{|c|c|c|c|c|c|c|c|c|c|}
\hline & $\begin{array}{l}\text { CRITÉRIOS } \\
\text { DE } \\
\text { AVALIAÇÃO }\end{array}$ & 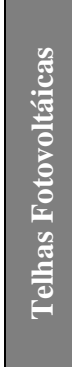 & 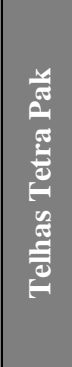 & 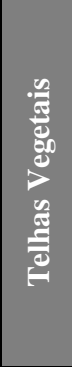 & 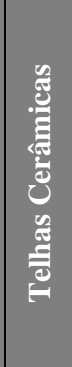 & 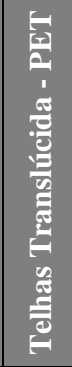 & 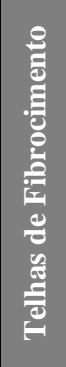 & 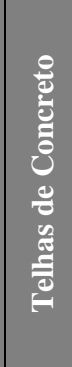 & OBJETIVOS \\
\hline & Conforto visual & 1 & 1 & 2 & 2 & 3 & $\mathbf{n} / \mathbf{a}$ & 2 & $\begin{array}{l}\text { Para garantir a iluminação natural e } \\
\text { artificial e o controle dos ocupantes. Para } \\
\text { garantir o melhor desempenho visual e } \\
\text { conforto para os ocupantes do edifício. }\end{array}$ \\
\hline & $\begin{array}{c}\text { Qualidade } \\
\text { sanitária do ar }\end{array}$ & 1 & 1 & 1 & 1 & 1 & $\mathbf{n} / \mathbf{a}$ & 1 & $\begin{array}{l}\text { Ventilação eficiente. Controle das fontes } \\
\text { de poluição interna. Controle das fontes de } \\
\text { poluição externa. }\end{array}$ \\
\hline & $\begin{array}{l}\text { Fontes } \\
\text { eficientes de } \\
\text { aquecimento } \\
\text { solar/Sistema de } \\
\text { aquecimento } \\
\text { solar }\end{array}$ & 4 & 2 & 2 & 1 & 2 & $\mathbf{n} / \mathbf{a}$ & 2 & $\begin{array}{l}\text { Incentivar a adoção de fontes de energia } \\
\text { renovável, promovendo a redução do } \\
\text { consumo de energia utilizada para o } \\
\text { aquecimento de água, por meio de } \\
\text { utilização de Sistemas de Aquecimento } \\
\text { Solar (SAS), ou por meio de Sistemas de } \\
\text { Recuperação de Calor e reduzir as perdas } \\
\text { térmicas relativas à distribuição de água } \\
\text { quente, diminuindo a carga energética } \\
\text { demandada pelos edifícios. Reduzir o } \\
\text { consumo de energia solar elétrica ou de gás } \\
\text { para o aquecimento de água. }\end{array}$ \\
\hline & $\begin{array}{l}\text { Materiais } \\
\text { ambientalmente } \\
\text { preferíveis }\end{array}$ & 2 & 3 & 3 & 2 & 3 & 1 & 2 & $\begin{array}{l}\text { Utilizar materiais incorporados ou não à } \\
\text { construção que sejam regionais, } \\
\text { provenientes de reuso, com conteúdo } \\
\text { reciclado, de rápida renovação e } \\
\text { recicláveis, visando reduzir as emissões de } \\
\text { dióxido de carbono }\left(\mathrm{CO}_{2}\right) \text { e a extração de } \\
\text { recursos naturais não renováveis. }\end{array}$ \\
\hline & $\begin{array}{l}\text { Desempenho } \\
\text { energético } \\
\text { aprimorado }\end{array}$ & 3 & $\mathbf{n} / \mathbf{a}$ & $\mathrm{n} / \mathrm{a}$ & $\mathrm{n} / \mathrm{a}$ & $\mathbf{n} / \mathbf{a}$ & $\mathbf{n} / \mathbf{a}$ & 1 & $\begin{array}{l}\text { Aprimorar o desempenho energético da } \\
\text { residência, superando o nível A estipulado } \\
\text { pelo selo Procel EDIFICA. }\end{array}$ \\
\hline & $\begin{array}{l}\text { Baixo e zero } \\
\text { emissões de } \\
\text { carbono }\end{array}$ & 2 & 2 & 3 & 1 & 3 & 1 & 2 & $\begin{array}{l}\text { Para reduzir as emissões de carbono e } \\
\text { poluição atmosférica, incentivando a } \\
\text { geração de energia local a partir de fontes } \\
\text { renováveis para abastecer uma proporção } \\
\text { significativa da demanda de energia. }\end{array}$ \\
\hline & $\begin{array}{l}\text { Obter o Procel } \\
\text { Edifica }\end{array}$ & 2 & $\mathrm{n} / \mathrm{a}$ & $\mathrm{n} / \mathrm{a}$ & $\mathrm{n} / \mathrm{a}$ & $\mathbf{n} / \mathbf{a}$ & $\mathbf{n} / \mathbf{a}$ & 1 & $\begin{array}{l}\text { Receber a etiquetagem Procel EDIFICA } \\
\text { nível A. }\end{array}$ \\
\hline & $\begin{array}{l}\text { Redução de } \\
\text { resíduos }\end{array}$ & 2 & 3 & 3 & 1 & 2 & 1 & 3 & $\begin{array}{l}\text { Utilização de projetos modulares e } \\
\text { sistemas desmontáveis para minimizar os } \\
\text { resíduos gerados pelos sistemas estruturais } \\
\text { na construção civil. Adoção de técnicas de } \\
\text { projeto e procedimentos para minimizar os } \\
\text { resíduos gerados na construção civil pelos } \\
\text { elementos não estruturais. }\end{array}$ \\
\hline
\end{tabular}




\begin{tabular}{|c|c|c|c|c|c|c|c|c|c|}
\hline & $\begin{array}{l}\text { CRITÉRIOS } \\
\text { DE } \\
\text { AVALIAÇÃOO }\end{array}$ & 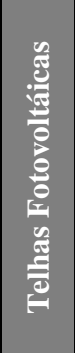 & 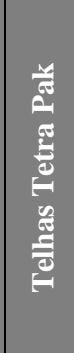 & 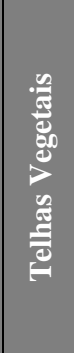 & 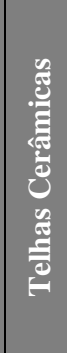 & 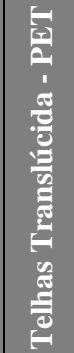 & 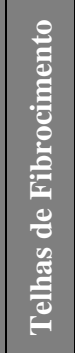 & 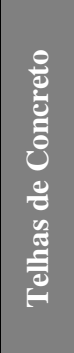 & OBJETIVOS \\
\hline & $\begin{array}{l}\text { Madeira } \\
\text { plantada ou } \\
\text { certificada }\end{array}$ & 1 & 1 & 1 & 1 & 1 & 1 & 1 & $\begin{array}{l}\text { Incentivar a utilização da madeira } \\
\text { certificada, por meio do emprego de } \\
\text { produtos provenientes de espécies nativas } \\
\text { devidamente legalizadas ou espécies } \\
\text { exóticas de rápido crescimento } \\
\text { (reflorestamento), e, consequentemente, } \\
\text { promover o manejo sustentável em toda a } \\
\text { cadeia produtiva madeireira. }\end{array}$ \\
\hline & $\begin{array}{l}\text { Qualidade de } \\
\text { materiais } \\
\text { componentes }\end{array}$ & 2 & 3 & 4 & 2 & 3 & $\mathrm{n} / \mathrm{a}$ & 3 & $\begin{array}{l}\text { Evitar o uso de produtos de baixa } \\
\text { qualidade, reduzindo o consumo de } \\
\text { produtos naturais utilizados na correção e } \\
\text { custos da correção de defeitos, além de } \\
\text { melhorar as condiçç̃es de competitividade } \\
\text { dos fabricantes que operam em } \\
\text { conformidade com a normatização. }\end{array}$ \\
\hline & Durabilidade & 3 & 3 & 3 & 2 & 3 & 1 & 3 & $\begin{array}{l}\text { Para reconhecer e incentivar a proteção } \\
\text { adequada dos elementos expostos do } \\
\text { edifício e da paisagem, minimizando assim } \\
\text { a frequência de substituição e } \\
\text { maximizando a otimização de materiais. }\end{array}$ \\
\hline & $\begin{array}{l}\text { Impacto em } \\
\text { longo prazo } \\
\text { sobre a } \\
\text { biodiversidade }\end{array}$ & 2 & 2 & 3 & 2 & 3 & 1 & 3 & $\begin{array}{l}\text { Para minimizar o impacto em longo prazo } \\
\text { do desenvolvimento no local e na } \\
\text { biodiversidade da área circunvizinha. }\end{array}$ \\
\hline \multirow{2}{*}{ 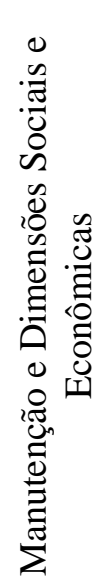 } & $\begin{array}{l}\text { Manual do } \\
\text { usuário }\end{array}$ & 1 & 1 & 1 & 1 & 1 & $\mathrm{n} / \mathrm{a}$ & 1 & $\begin{array}{l}\text { Desenvolver um guia que contenha } \\
\text { informações sobre os equipamentos e } \\
\text { sistemas instalados e como operá-los, para } \\
\text { que a mesma mantenha seu desempenho } \\
\text { elevado ao longo de sua vida útil. }\end{array}$ \\
\hline & $\begin{array}{l}\text { Educação } \\
\text { ambiental dos } \\
\text { empregados }\end{array}$ & 2 & 2 & 3 & 1 & 3 & 1 & 3 & $\begin{array}{l}\text { Prestar informações e orientar os } \\
\text { trabalhadores sobre a utilização dos itens } \\
\text { de sustentabilidade do empreendimento, } \\
\text { notadamente sobre os aspectos ambientais. }\end{array}$ \\
\hline
\end{tabular}




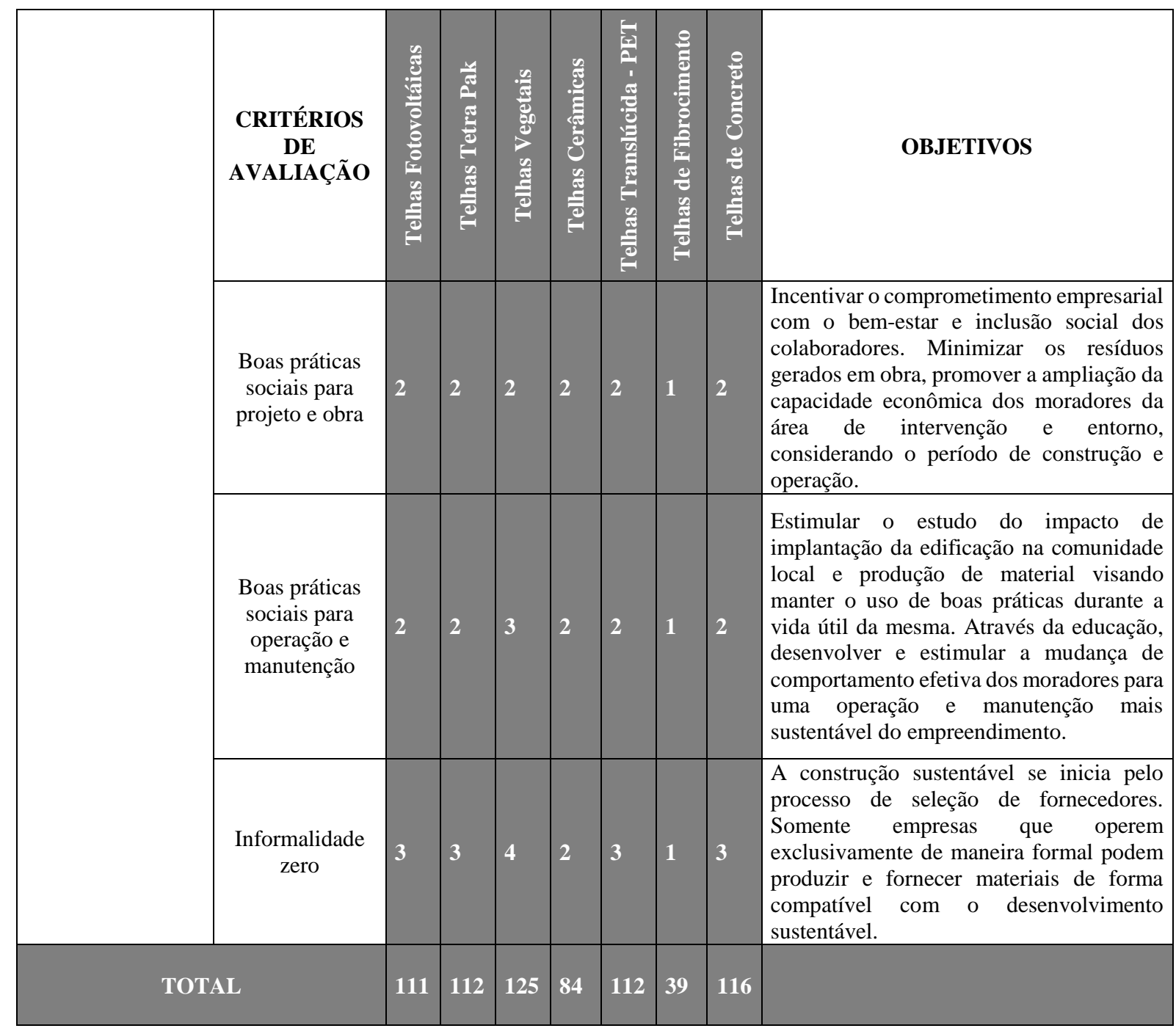

Utilizando o resultado das pontuações no quadro de qualificação de $\mathrm{A}$ à $\mathrm{E}$, sendo $\mathrm{A}$ correspondente a melhor pontuação e E correspondente à pior pontuação, tem-se o seguinte resultado na Tabela 5.2 — Resultados - Quadro de avaliação.

Tabela 5.2 Resultados - Quadro de Avaliação.

\begin{tabular}{|c|c|c|c|c|c|c|c|c|c|}
\hline \multicolumn{2}{|c|}{$\mathrm{E}$} & \multicolumn{2}{|c|}{ D } & \multicolumn{2}{|c|}{$\mathrm{C}$} & \multicolumn{2}{|c|}{ B } & \multicolumn{2}{|c|}{ A } \\
\hline \multirow{2}{*}{\multicolumn{2}{|c|}{--- }} & \multirow{2}{*}{\multicolumn{2}{|c|}{$\begin{array}{c}\text { Telhas de } \\
\text { Fibrocimento }\end{array}$}} & \multirow{2}{*}{\multicolumn{2}{|c|}{$\begin{array}{c}\text { Telhas } \\
\text { Cerâmicas }\end{array}$}} & Fot & s & \multicolumn{2}{|c|}{$\begin{array}{l}\text { Telhas de } \\
\text { Concreto }\end{array}$} \\
\hline & & & & & & \multicolumn{2}{|c|}{$\begin{array}{c}\text { Telhas Translúcidas } \\
\text { - Pet }\end{array}$} & \multicolumn{2}{|c|}{ Telhas Vegetais } \\
\hline 01 & 28 & 29 & 56 & 57 & 84 & 85 & 112 & 113 & 140 \\
\hline
\end{tabular}


Entende-se por este resultado que as telhas de fibrocimento tiveram o pior resultado, somando 39 pontos, sendo classificada na qualificação D. Logo em seguida temos as telhas cerâmicas com 84 pontos, que apesar de serem telhas ecológicas e possuir rigorosos controles de qualidade exigidos pela ABNT e INMETRO (conforme fabricante), ainda não se qualificam com pontuação suficiente para preencher todos os quesitos de sustentabilidade exigidos pelos selos estudados. As telhas fotovoltaicas, tetra pak e translúcidas de garrafa pet apresentaram uma pontuação melhor, somando 111, 112 e 112 pontos respectivamente, ficando na qualificação B. A matéria prima de produção das telhas fotovoltaicas ainda não tem sua fabricação na linha ecológica, porém obtiveram boa pontuação na tabela de qualificação por serem sustentáveis no quesito de energia, tendo grande parte dos pontos fornecidos pelo Selo PROCEL. No caso das telhas translúcidas, a qualificação se deu grande parte por estar enquadrada também no quesito de economia de energia, proporcionando luz natural, além de outros atributos conforme tabela acima. Um dos motivos da qualificação B para as telhas tetra pak é o processo de reciclagem, tendo o cuidado e atenção tanto na produção das telhas quanto no uso das mesmas. As telhas que obtiveram melhores notas foram as telhas vegetais com 125 pontos e a telhas de concreto com 116 pontos. Todo o processo de produção e execução das telhas vegetais foi feito pensando na sustentabilidade. Já as telhas de concreto ganham boa pontuação também no quesito de durabilidade.

Desta forma, em porcentagens, a distribuição ficou conforme Tabela 5.3:

Tabela 5.3 Quadro de avaliação - Resultados em porcentagens.

\begin{tabular}{|c|c|c|c|c|c|}
\hline QUALIFICAÇÃO & PORCENTAGENS & PONTUAÇÃO & \multicolumn{2}{|c|}{ PONTUAÇÃO } \\
OBTIDA
\end{tabular}


Com o resultado da aplicação dos produtos no método de qualificação, foi possível criar um gráfico (Figura 5.1) de comparação da sustentabilidade segundo as Certificações e os Selos apresentados e estudados no decorrer deste trabalho.

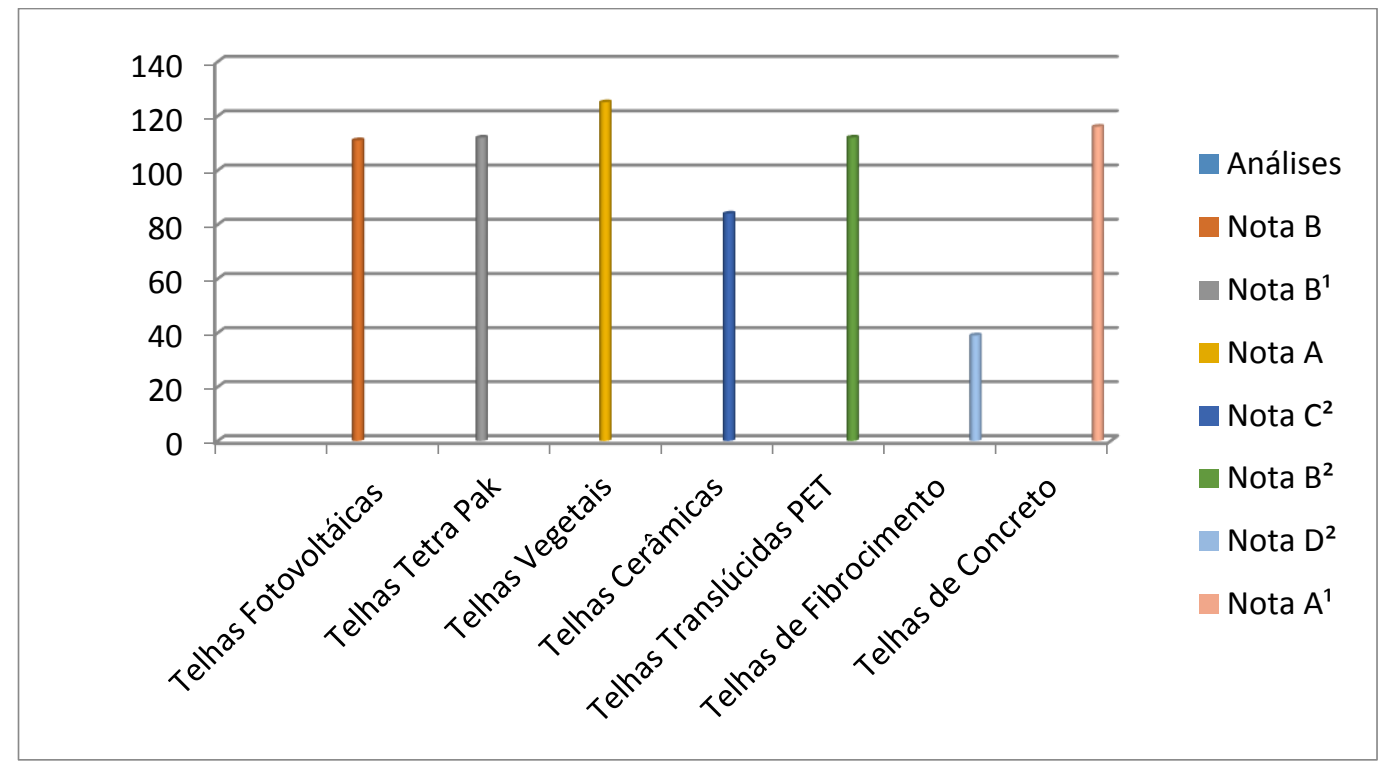

Figura 5.1- Pontuação na sequência dos produtos na avaliação da sustentabilidade.

No gráfico acima, têm-se as notas específicas para cada produto juntamente com a pontuação máxima de 140 pontos de acordo com a qualificação a partir dos Selos Sustentáveis estudados. 


\section{CONCLUSÃO}

Este trabalho visa aumentar o conhecimento das Certificações Ambientais, mais precisamente no que abrange o estudo das telhas no contexto ecológico. Observa-se ainda, que algumas das empresas avaliadas já estão trabalhando com a visão sustentável e tentam aprimorar a qualidade no desenvolvimento, produção e desempenho dos seus produtos.

Mesmo com esforço em tornar seus produtos mais sustentáveis, temos, por outro lado, relatos apresentados em sites de dedicados a reclamações de usuários demonstrando suas insatisfações com alguns dos produtos. As telhas de fibras vegetais obtivem alta pontuação nas tabelas apresentadas, todavia, a insatisfação refere-se às Telhas Vegetais Onduline. Dentre algumas características negativas foram observadas o mau funcionamento do telhado se não tiver uma mão de obra qualificada para a sua instalação. O calor também é um problema porque empena as telhas. Alguns desses relatos referem-se ao betume aplicado na parte inferior das telhas para impermeabilização, pois com mudanças de temperatura, este tende a derreter. Como as telhas são leves e a estrutura do telhado também, já houve casos em que uma ventania levou as telhas instaladas e a edificação ficou sem cobertura. Algumas destas reclamações também foram relatadas sobre as telhas de fibrocimento. Esses relatos estão sendo mencionados a título de pesquisa exclusivamente das telhas vegetais Onduline e fibrocimento Eternit. As tabelas de qualificação dos atributos para efeito sustentável são feitas tendo como referência as telhas de fibras vegetais em um contexto geral e não especificamente as da marca Onduline. Assim também no que diz respeito às telhas de fibrocimento.

No âmbito do trabalho desenvolvido, apresenta-se um resumo dos atributos e critérios estabelecidos pelas principais ferramentas de avaliação ambiental utilizadas no mercado brasileiro. Foram analisadas as tabelas resumo referentes aos Selos BREEAM, LEED, AQUA, CASA AZUL e PROCEL EDIFICA, cada qual com suas características específicas, que geraram novas tabelas comparativas utilizadas nos critérios de avaliação. A partir deste ponto, as coberturas apresentadas foram analisadas para avaliação do resultado final de sustentabilidade de cada telha.

Vale ressaltar que os materiais que são considerados ecológicos, são materiais que possuem fonte renovável, como a madeira certificada - um dos critérios do LEED - e que possam ser reutilizados, renovados ou reciclados. Vimos alguns destes exemplos nas telhas 
Tetra Pak, onde foram recicladas das caixinhas de leite e nas Telhas Vegetais, onde sua matéria prima é obtida das fibras vegetais de papel reciclado.

Por meio desta pesquisa, mostra-se a importância deste tema dentro do contexto da construção civil. Foi escolhida a vertente: Coberturas - Tipos de Telhas para desenvolver a dissertação. Há várias maneiras de se preservar o meio ambiente e evitar o impacto ambiental, mas precisamos ter consciência que isso é um trabalho em conjunto. A intenção proposta aqui foi sensibilizar os profissionais da área quanto ás soluções que podem ser adotadas em relação ao envoltório das edificações quanto às escolhas dos tipos de coberturas existentes. 


\section{Anexo I - Certificado de Garantia: Telhas Vasatex}

\section{告 VASAtex \\ Certificado de Garantia}

Certficamos ao consumidor abaiwo identficado ce prazos de garantia descritos neste documerto, referentes so item PRAZOS DE GARANTIA o(s) produto(8) adquirido(8), validos a conter da deta da compra, mediante Note Fiscal de comora do revendedor, contra nao-conformidades, de acardo com as nomas INMETROUCCB vigentes

\section{OBJETO DE GARANTIA}

PRAZOS DE GARANTIA

10 (dez) ances para todos ces produtos em seu estado natural

10 (dez) ance para o hidrofugante aplicado nos produtoe naturais.

NORMATIZACOES QUE DETERMINAM A QUALIDAOE DOS PRODUTOS DAS MARCAS VASATEX: CERTIFICADOS expedidos PELO INMETROICCB - OCP-OTD - Tolhas modelos -Duplanatex Ecologic e Portuguesa. $O$. demais modelos de telhas têm suas esoecificaç゙es fisicas e dimensionais definidos de acordo com a norma NBR

ITENS NAOO COEERTOS POR ESTA GARANTLA

t -Mío de obra de instalaçảo das felhas e outros materiais relativos à cobertura do teihado;

2 - Escurecimento ou mancha nas telhas causadas por algas, fungos, eflorescancis, poluiça ou qualquer outro agente naturai:

3-Dance causados pelo manuseio, amazenamento e instalaçẫo insdequados to produho.

4 -Danos resustantes de atos deliberados, acidentais ou de mau uso do produto

5. -Dances ocarridos em funçăo de mavimento do solo ou por empenamenta cu falha na estrutura to telhadp;

6 -Danos gerados por forças da natureza, como tomentas, faios, terremotos, furacóes e ventos eacepcionaimente fortes:

7 -Dancs gerados em casos fortuitos como dapredap̧es, guerras, revaluçbes e tumultos:

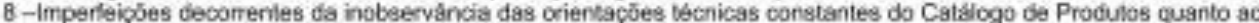
cálculo da gaiga, inclinaçäo do telhado e colocacto de cumeeiras;

Q.A formacha de gotas proverientes da condensaccala da umidade interna do ambiente;

10-Danos causados por alteraçess as caracteriaticas ofiginais do[s) produto(s).

RESPONSABILIDADE DAFABRICANTE DAS MARCAS VASATEX

Na ococréncia de problemas cobenos por este Certficado de Garantia, a empresa responsabiliza-se por:

a) Efetuar a reposicaso das telhes cobertas pela garantia, thre de quaisquer ónus as compradoc. Caso as telhas nas

façam mais parte da linha de produtos da maroa Vasatex, a reposiçilo sera feita por linha similar.

b) Disponibifizar Assisténcia Tecnica para orientaçảo do comprador

As dividas existantes sobre o conreto manuspio es instalacto das telhas garantidas por este certficado derverăo ser

dirmidas junto a Ares Ternica e de Qualidade das ceramicas que produzem as teinas com as marcas Vhasertex, antes đe sua utlizaçẩo.

IMPORTANTE

1 -As têhas đa marca Vasatex poderăo ter suas caracteristicas gerais, técricas e estéticas alteradas, sem aviso prèvio.

Fonte: <www.ceramicavasatex.com.br>. Acesso em 28 jan. 14. 
Anexo II - Certificado Madeira Legal: Intercil - empresa fabricante dos produtos Vasatex

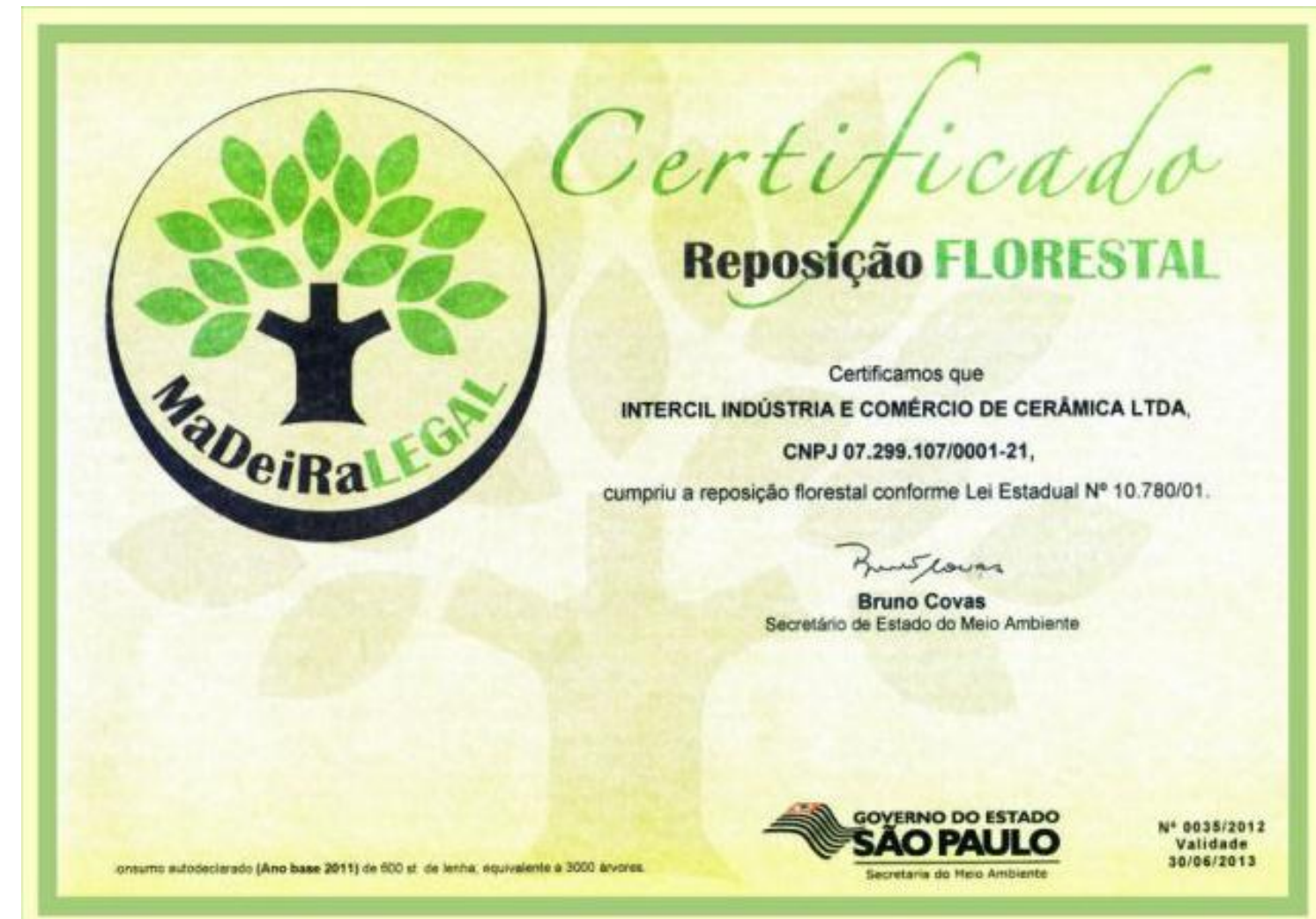

Fonte: 〈http://www.ceramicavasatex.com.br/?go=novidades $>$. Acesso em 28 jan.14 


\section{Anexo III - Tipologias - Coberturas}

Tabela 5: Tipologias - coberturas

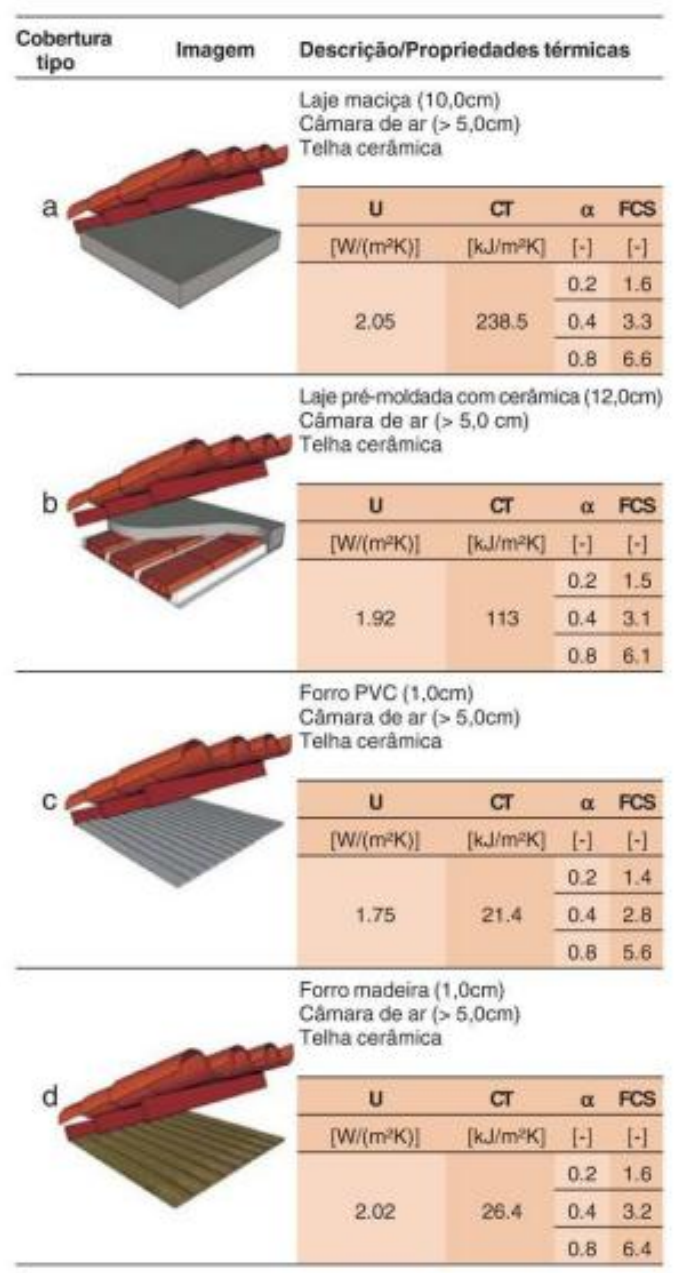

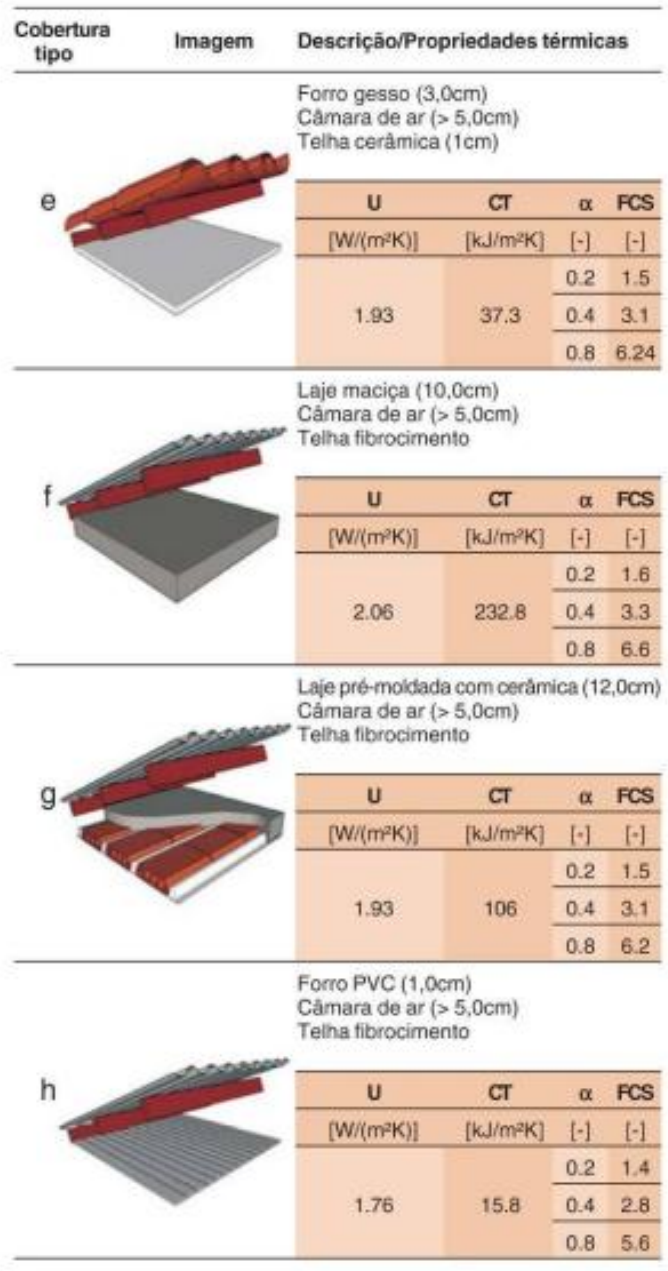

Fonte: MAGNANI, 2011 
Anexo IV - Propriedades Térmicas - Coberturas

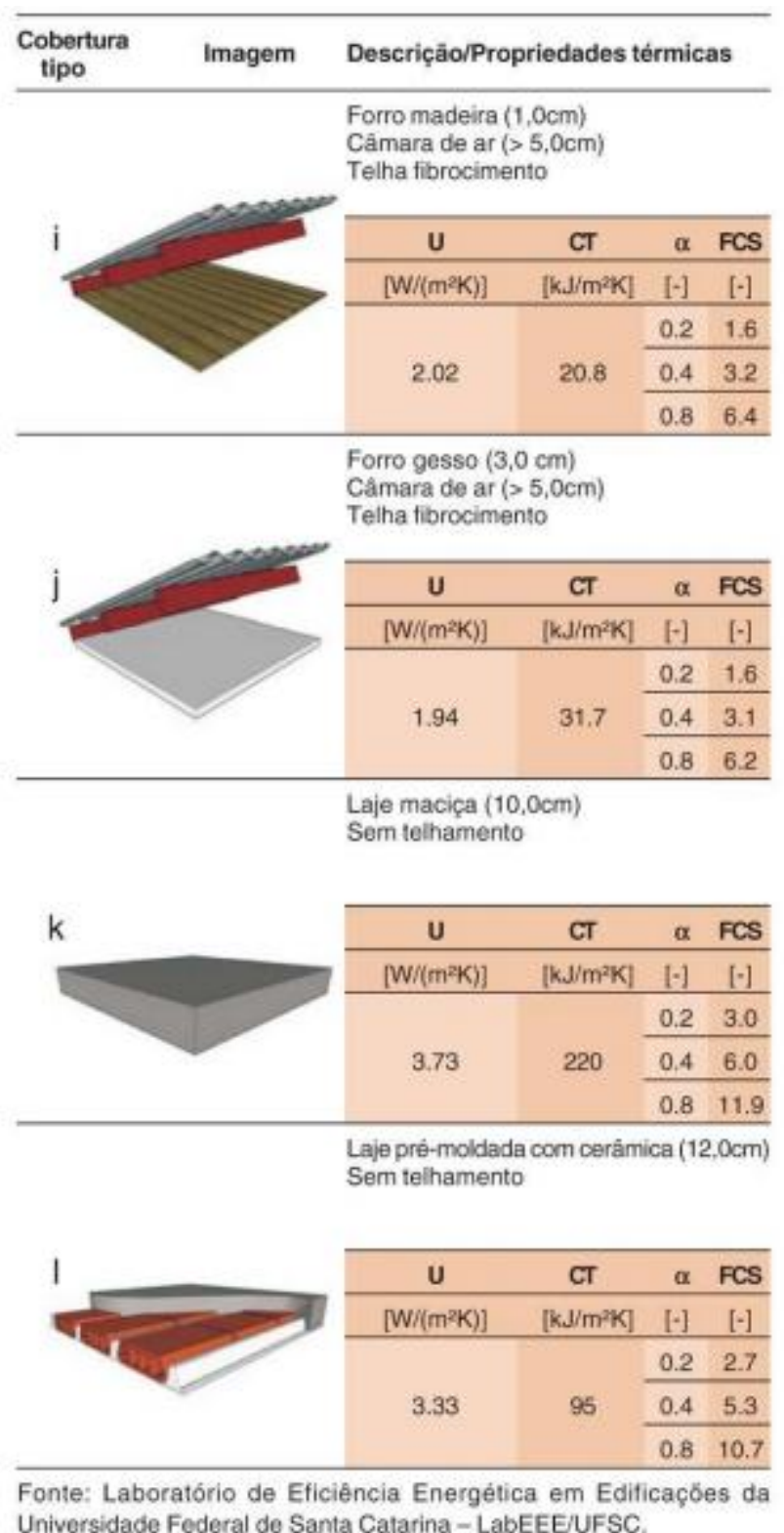

Fonte: MAGNANI, 2011 


\section{Anexo V - Telhas LEVE - ECCOCLEAN}

As telhas "Leve" da Eccoclean são telhas 100\% recicladas de garrafas PET de ação pósconsumo e pós-indústria, limpas e refinadas no próprio local. A fabricação é feita com a tecnologia state-of-the-art (tecnologia de ponta) para produzir telhas altamente resistentes. São impermeáveis, não criam limo nem fungo e não escurecem com o tempo. Também são pigmentadas na fabricação, desta forma não descolorem, mantendo o telhado por anos com a mesma aparência. As telhas pesam menos de $6 \mathrm{~kg}$ por $\mathrm{m}^{2}$, gerando uma economia na estrutura do telhado e tem vida útil de aproximadamente 40 anos.

\section{Procedimento de fabricação das telhas Eccoclean}

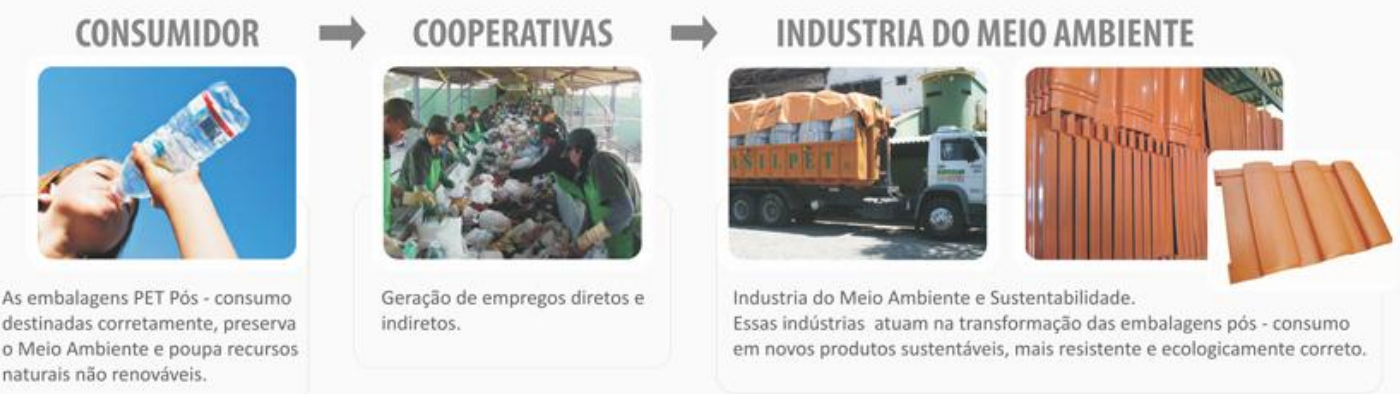

Fonte: <http://www.eccoclean.com.br/empresa.html>. Acesso em 03 fev.15
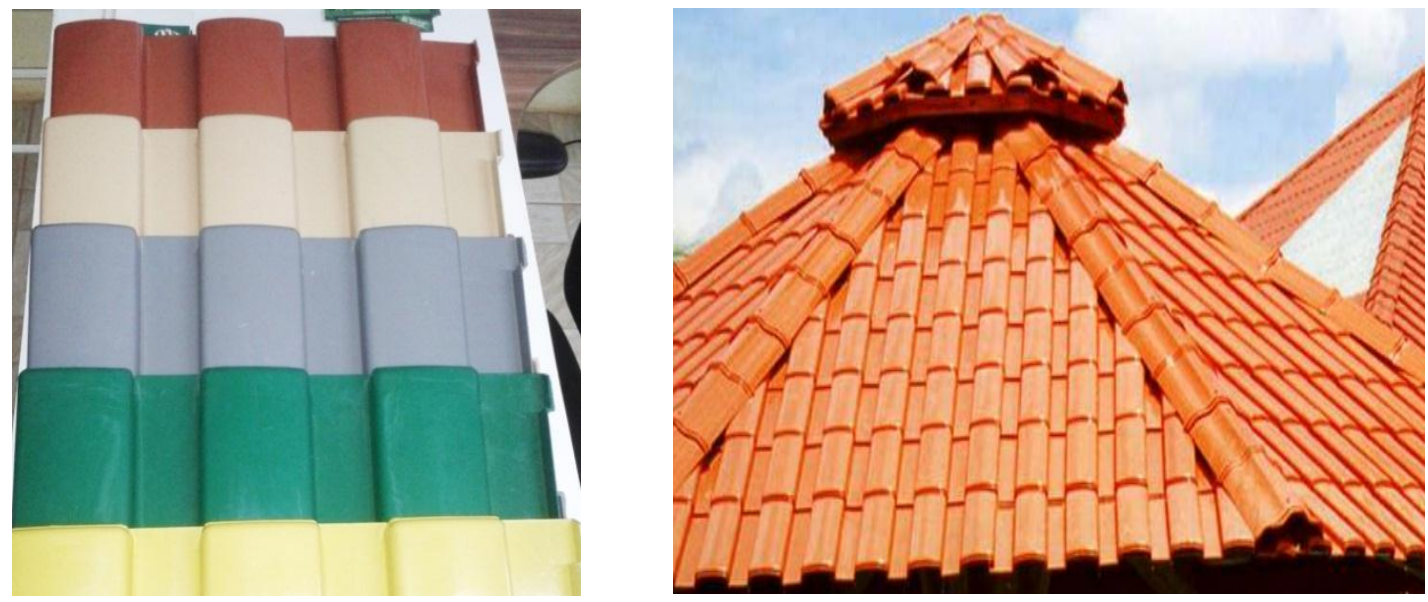


\section{Anexo VI - Placas Solares}

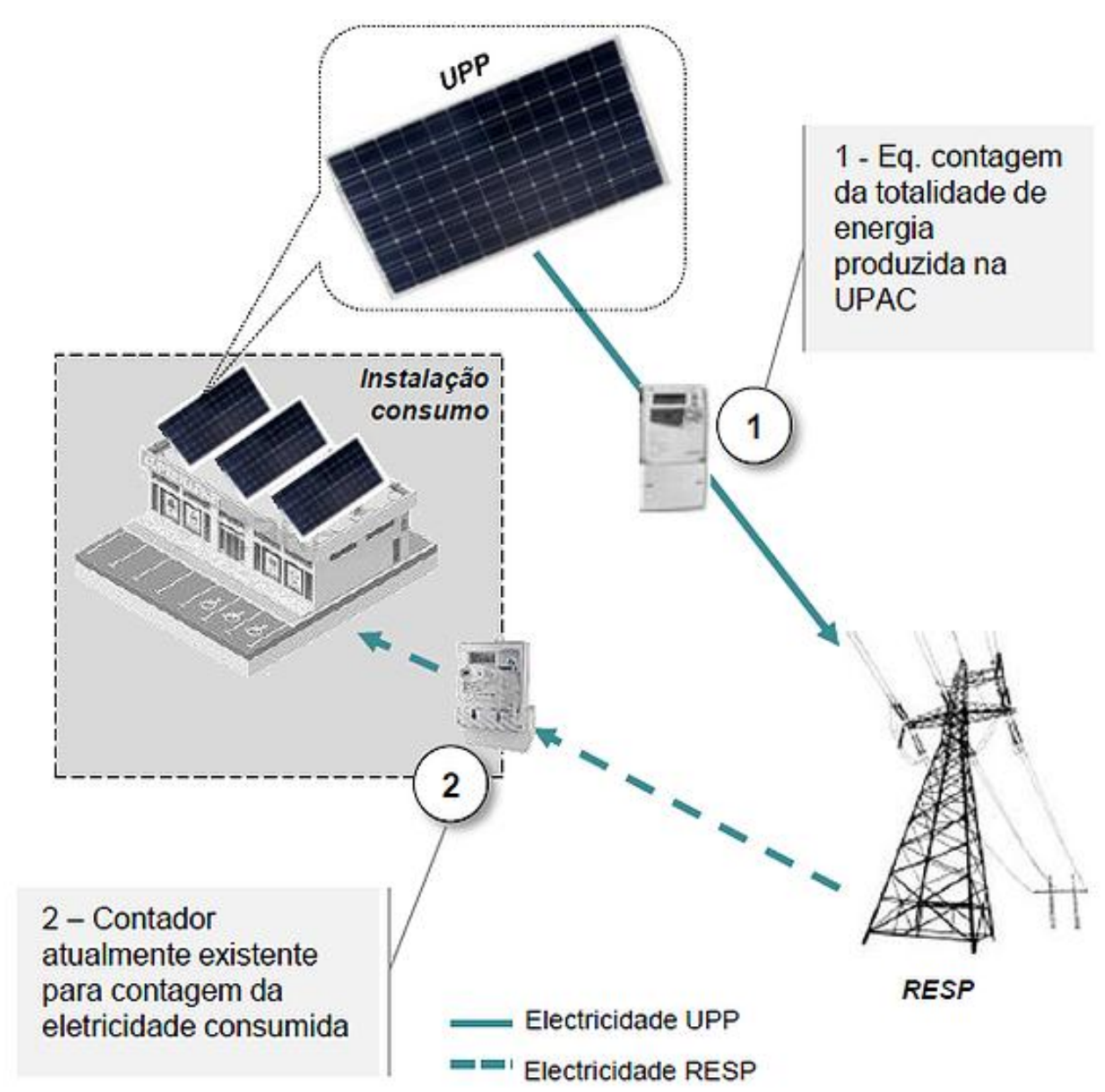

Fonte: www.portugal.gov.pt

Fonte: <http://www.d-solarsystems.com/\#!unidade-pequena-producao/cppe>. Acesso em 29 dez 14.

A Unidade de Pequena Produção (UPP) é um investimento de longo prazo. O investidor adquire um sistema fotovoltaico e vende a energia produzida à rede.

Funciona substituindo os anteriores regimes de microprodução e miniprodução. A UPP é instalada num local de consumo e a energia produzida é totalmente injetada na rede pública (RESP) 


\section{Anexo VII - Placas Solares}

Um sistema de autoconsumo permite produzir localmente a sua própria energia e contribuir diretamente para a redução dos custos energéticos da habitação / empresa.

A unidade de produção (UPAC) produz energia preferencialmente para satisfazer necessidades de consumo.

A energia elétrica produzida é instantaneamente injetada na instalação de consumo.

O excedente produzido é injetado na RESP, evitando o desperdício

A UPAC é instalada no local de consumo.

A Potência de ligação da UPAC tem de ser inferior à potência contratada na instalação de consumo.

A Potência da UPAC não pode ser superior a duas vezes a potência de ligação.

Fonte: <http://www.d-solarsystems.com/\#! unidade-pequena-producao/cppe>. Acesso em 29 dez 14. 


\section{Anexo VIII - Projeto Tamar}

Conforme a empresa responsável pelo projeto de energia solar, DONAUER, a eletricidade solar do Projeto Tamar é consumida de imediato nas instalações do mesmo e a eventual energia excedente é injetada na rede pública. As instalações irão fornecer energia limpa nas próximas décadas, protegendo o ambiente e apostando na sustentabilidade. Este projeto faz parte do "Programa telhado Solar" da DENA (Agência Alemã de Energia).

\section{Telhado da Loja do Tamar:}

- 12 painéis solares de $240 \mathrm{Wp}$

- Potência total: $2,88 \mathrm{kWp}$

- Superfície da instalação: $20 \mathrm{~m}^{2}$

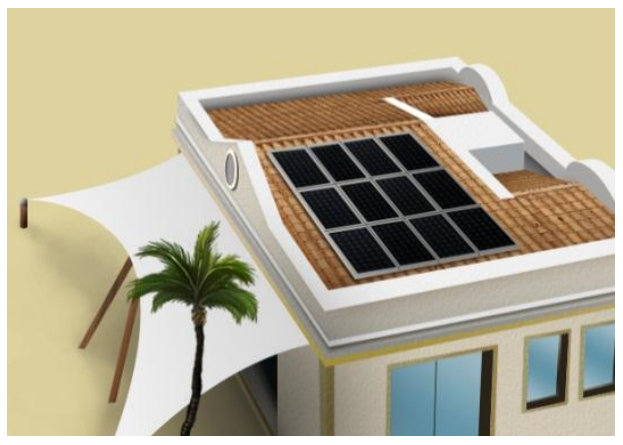

\section{Pérgola solar:}

- 72 painéis solares de $120 \mathrm{Wp}$

- Potência total: $8,64 \mathrm{kWp}$

- Superfície da instalação: $86 \mathrm{~m}^{2}$

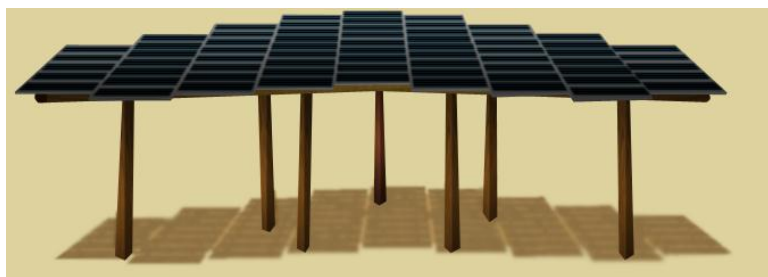

\section{Energia Solar}

A energia solar é toda e qualquer captação de energia, luminosa ou térmica, oriunda do sol, com transformação dessa energia para uso humano. Em geral há dois tipos

de captação de energia solar: para aquecimento ou para geração de energia elétrica.

No projeto Tamar, toda energia solar captada é transformada em energia elétrica a

partir do uso de painéis solares compostos por células fotovoltaicas. Essas células

são dispositivos elétricos capazes de converter a luz diretamente em energia elétrica. Conheça as principais vantagens do uso da energia solar:

- É uma energia limpa que não gera poluição;

- Necessidade de manutenção extremamente reduzida

- Economicamente viável ao longo do tempo;

- Excelente em locais de difícil acesso.

\section{Componentes}

1. Vidro

2. Película solar de EVA

3. Célula fotovoltaica

4. Película solar de EVA

5. Interligação

6. Película de suporte

7. MC4-plug

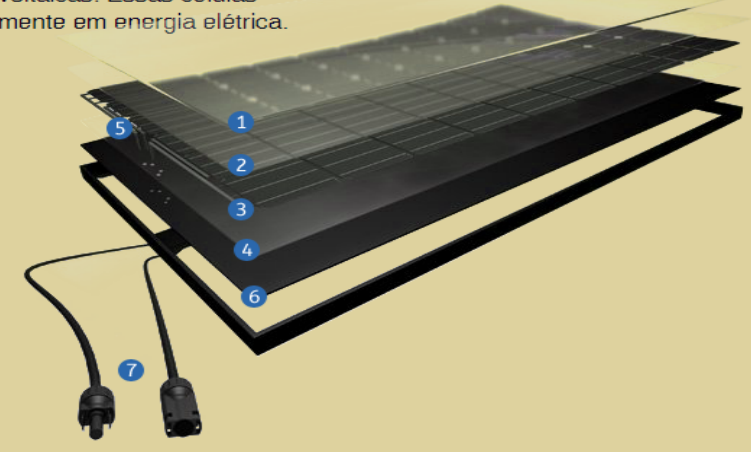

Fonte: <www.projetotamar.com.br>. Acesso em 30 jan. 14. 


\section{Anexo IX - Certificados Telhas De Concreto Tégula}

\section{Certificade de Conformidade de Produte}

O Centro Cerâmico do Brasil | CCB certifica que o produto Telha de Concreto modelos Perfil Tradição e Big fabricados pela empresa

Tégula Soluções para Telhados Ltda
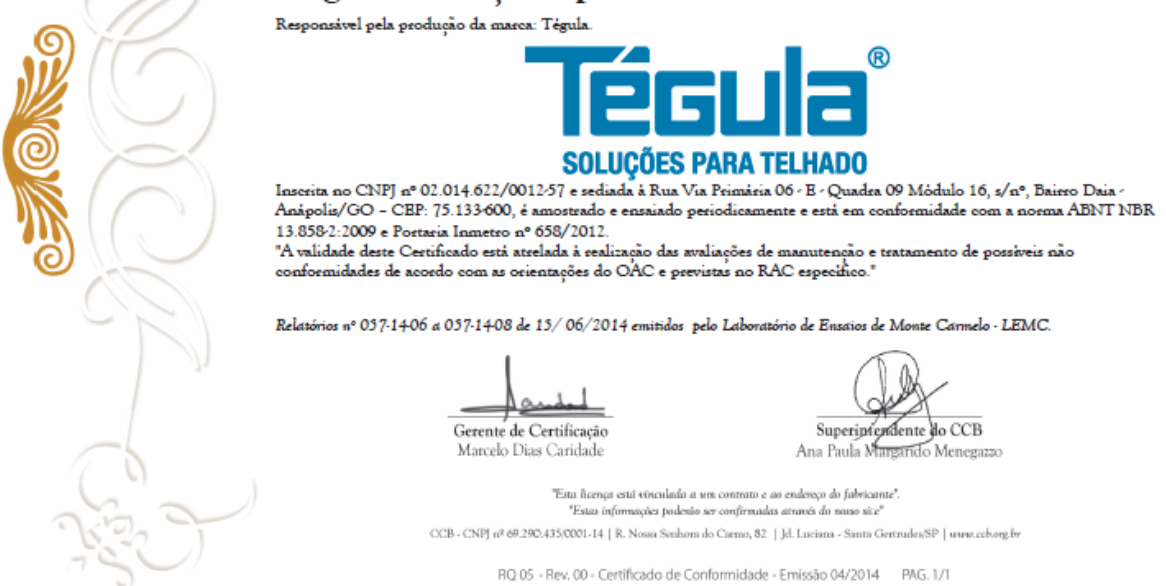

TCo o10/0101

Certificascio

07/00/2010

ecertificas

15/03/2013

$19 / 03 / 2010$

Emissio

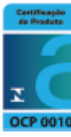

\section{Certificade de Conformidade de Produte}

O Centro Cerâmico do Brasil | CCB certifica que o produto Telha de Concreto modelos

Tradição, Plana e Big fabricados pela empresa

Tégula Soluções para Telhados Ltda
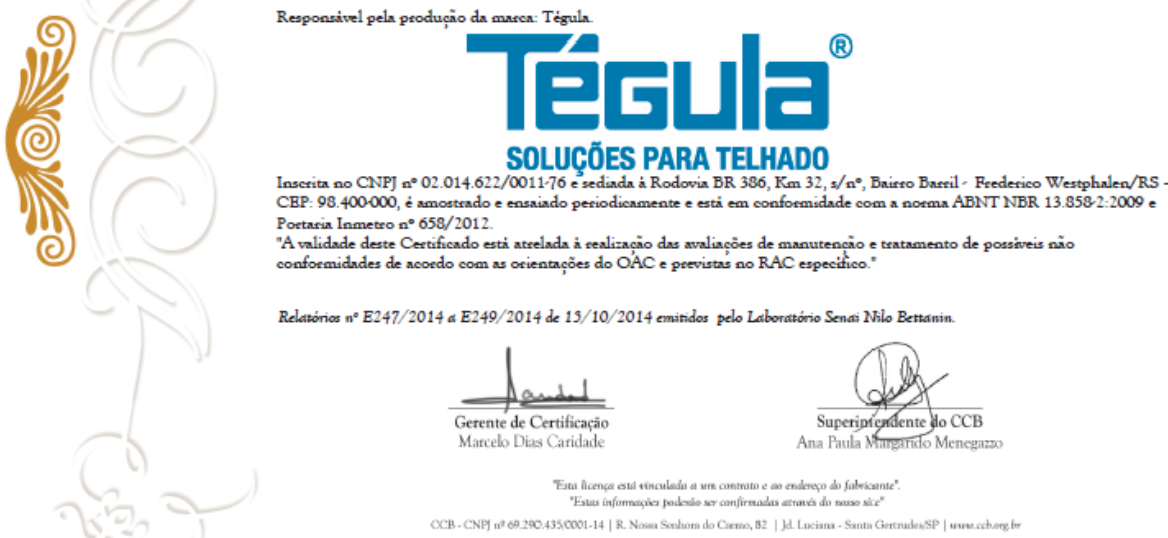

Certificando

$\pi c 000 \% / 002$

$0 \% / 00 / 2000$

Recertificaşio

Validade

Emissio

CSipo NACE

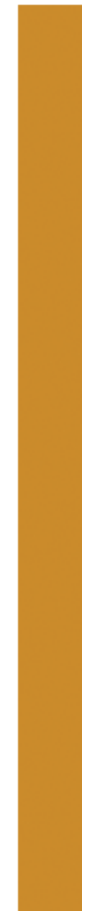


Certificade de Conformidade de Produte o Centro Cerâmico do Brasil | CCB certifica que o produto Telha de Concreto modelos Tradição e Big fabricados pela empresa

Tégula Soluções para Telhados Ltda
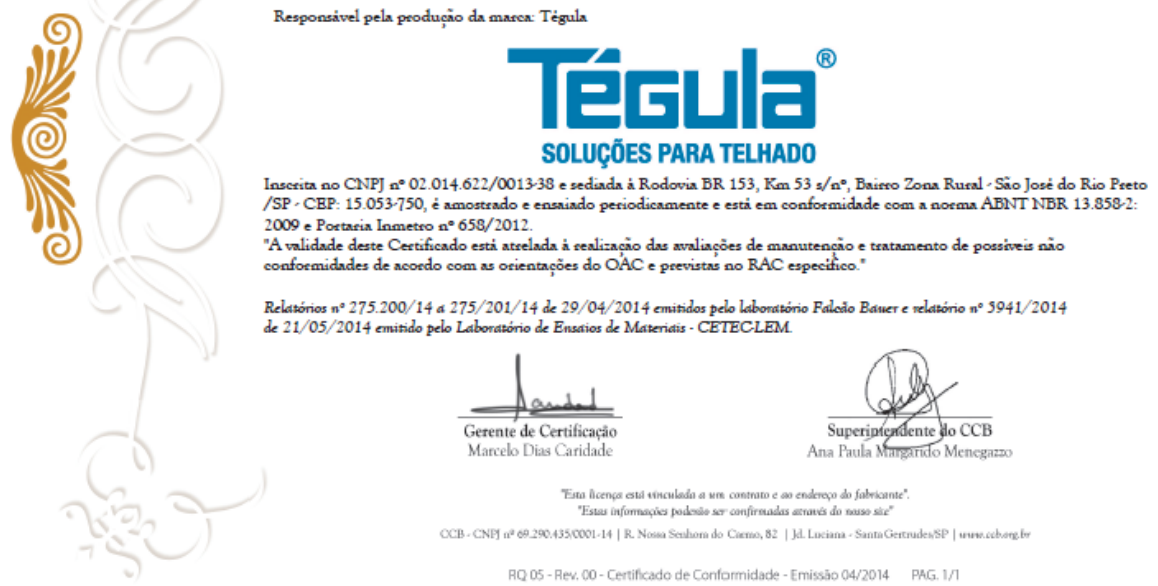

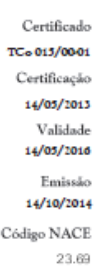

Fonte: <www.tegula.com.br>. Acesso em 25 set. 15 


\section{REFERÊNCIAS}

ALMEIDA, Fernando. O bom negócio da sustentabilidade. Rio de Janeiro: Nova Fronteira, 2002.

ARAÚJO, Márcio Augusto. A moderna construção sustentável. Instituto para o Desenvolvimento da Habitação Ecológica. 2005. Disponível em: <www.idhea.com.br/pdf/moderna.pdf>. Acesso em 22 jun. 13.

AULICINO, Patrícia. Análise de métodos de avaliação de sustentabilidade do ambiente construído: o caso dos conjuntos habitacionais. São Paulo: Escola Politécnica da Universidade de São Paulo, 2008.

BEZERRA NETO, Sebastião Luiz. Sustentabilidade na construção civil. Disponível em: $<$ http://meuartigo.brasilescola.com/atualidades/sustentabilidade-na-construcao-civil.htm>.

BLUMENSCHEIN, Raquel Naves. A sustentabilidade na cadeia produtiva da indústria da construção. Tese de Doutorado. Universidade de Brasília, Doutor, Política e Gestão Ambiental, 2004.

BODÃO, Juliano Henrique. Desenvolvimento colaborativo de telhas fotovoltaicas em RCD. Dissertação de Mestrado, Universidade Federal do Paraná, 2014.

CÓDIGO DE EDIFICAÇÕES DO DISTRITO FEDERAL - Lei 2.105/98 e Decreto 19.915/98 e alterações. Seção IV (Acessibilidade). Coordenadoria das Cidades 25/05/14

FAGUNDES, Renata Magalhães. Aplicação do RTQ-R na avaliação da eficiência energética de edificações multifamiliares de interesse social para as zonas bioclimáticas brasileiras. Dissertação de Mestrado, Universidade Federal de Santa Maria, 2014.

JALES, Fernando Fernandes. Utilização de embalagens tetra pak como material de construção. Mossoró, 2013.

KEELER, Marian; BURKE Bill. Fundamentos de projetos de edificações sustentáveis. Porto Alegre: Bookman, 2010.

LANNOY, Milena Canabrava e Souza de. Especificações de pisos e revestimentos: um exercício de aplicação de critérios da sustentabilidade. Dissertação de Mestrado. Universidade de Brasília, 2013. 
LE GOFF, Jacques. A Civilização do Ocidente Medieval. Editora: Edusc, Ano: 2005, $1^{\text {a }}$ edição.

MAGnANi, Juliana Matos. Análise comparativa do Selo Casa Azul e do Sistema de Certificação LEED for homes. Trabalho de Monografia de Pós-Graduação da Escola de Engenharia. Universidade Federal de Minas Gerais, 2011.

MATEUS, Ricardo F.M.S. Avaliação da sustentabilidade da construção. Propostas para o desenvolvimento de edifícios mais sustentáveis. Tese de Doutorado, Universidade de Minho, Portugal, 2009.

MONTEIRO, Eliane. A importância da sustentabilidade para empregadores e empregados (Administração). E-FACEQ: revista dos discentes da Faculdade Eça de Queiros, ISSN 2238-8605, Ano 1, número 1, Agosto de 2012. Disponível em: <e-faceq.blogspot.com.br〉. Acesso em 27 out. 2015.

NICARETTA, Francielle; FRANÇA, Rosiléa Garcia; ROSSONI, Patrícia; PILLAR, Rebecca Iva C.S. III-115 - produção de telhas a partir da reutilização de embalagens tetra pak e tubos de pasta dental. $26^{\circ}$ Congresso Brasileiro de Engenharia Sanitária e Ambiental. ABES Associação Brasileira de Engenharia Sanitária e Ambiental 1, Santa Catarina.

OLIVEIRA, Leonardo Pinto de. Estrutura metodológica para avaliação ambiental do projeto arquitetônico com base nos critérios prescritos e de desempenho das certificações para edifícios: estudo de caso edifício Gustavo Capanema e Eldorado Tower. Tese de Doutorado. Universidade de Brasília - DF, 2010.

PERALTA, Gisela. Desempenho térmico de telhas: análise de monitoramento e normalização específica. São Carlos: Universidade de São Paulo, 2006.

SILVA, V.G. Avaliação da sustentabilidade de edifícios de escritórios brasileiros: diretrizes e base metodológica. 2003. Tese (Doutorado) - Departamento de Engenharia Civil. Escola Politécnica da Universidade de São Paulo.

SILVA, Vanessa Gomes da. Avaliação de edifícios no Brasil: da avaliação ambiental para avaliação de sustentabilidade. 2003. Porto Alegre: Ambiente Construído.

\section{SITES PESQUISADOS}

AARQUITETA. Disponível em: <http://www.aarquiteta.com.br/blog/meio-ambiente-eplanejamento-urbano/telhas-solare/>. Acesso em 25 set. 14. 
AMBIENTE BRASIL. Amianto: proibição, uso controlado ou imobilização? Disponível em: $<$ http://ambientes.ambientebrasil.com.br/residuos/artigos/amianto\%3A_proibicao,_uso_contr olado_ou_imobilizacao\%3F.html>. Acesso em 15 out. 15.

AMBIENTES BRASIL. Disponível em: <htpp//www.ambientes.ambientebrasil.com.br>. Acesso em 27 jan. 2015.

ASSOCIAÇÃO BRASILEIRA DE NORMAS TÉCNICAS. NBR 15575-5_2013. Edificações habitacionais - Desempenho Parte 5: Requisitos para sistemas de coberturas. Disponível em: $<$ http://www.iar.unicamp.br/lab/luz/ld/normas\%20e\%20relat\%F3rios/NRs/NR\%2015575/NB R_15575-5_2013_Final\%20Sistemas\%20de\%20Cobertura.pdf $>$. Acesso em 27 out. 2015.

BARBOSA, Jaqueline. Telhado sustentável: conheça as telhas que produzem energia solar. Disponível em: <www.24harquitetura.blogspot.com.br>.

BBC BRASIL. Prédios argentinos pagarão menos imposto por ter jardins no telhado. <http://www.bbc.co.uk/portuguese/noticias/2013/02/130206_predios_verdes_argentina_jp_m c.shtml>. Acesso em 23 jun. 13.

BBC. Arquiteto constrói casa carbono zero com técnica medieval. Disponível em: $<$ http://www.bbc.co.uk/portuguese/noticias/2009/02/090218_casaverde_aw.shtml>. Acesso em 17 set. 14.

BONDE. Conheça benefícios e vantagens das telhas de concreto. Disponível em: <http://www.bonde.com.br/?id_bonde=1-32--14-20130611>. Acesso em 17 out. 15.

BRASIL ESCOLA. Disponível em: <http//meuartigo.brasilescola.com>. Acesso em 28 jan. 2015.

BRASIL. Lei $\mathrm{n}^{\circ}$ 12.484, de 8 de setembro de 2011. Dispõe sobre a Política Nacional de Incentivo ao Manejo Sustentado e ao Cultivo do Bambu e dá outras providências. Disponível em: <http://www.planalto.gov.br/ccivil_03/_ato2011-2014/2011/lei/112484.htm>. Acesso em 22 set. 14.

BREEAM. The world's leading design and assessment method for sustainable buildings. Disponível em: <http://www.breeam.org/>. Acesso em 06 out. 14.

CABO DE SANTO AGOSTINHO. Congresso Brasileiro de Engenharia sanitária e Ambiental. Disponível em: <htpp//www.cabo.pe.gov.br>. Acesso em 10 out. 2015. 
CAIXA ECONOMICA FEDERAL. Disponível em: <http://downloads.caixa.gov.br/_arquivos/ desenvolvimento_urbano/gestao_ambiental/SELO_CASA_AZUL_CAIXA_versaoweb.pdf >. Acesso em 01 dez. 14.

CAIXA ECONOMICA FEDERAL. Disponível em: <http://www14.caixa.gov.br/portal/ rse/home/produtos_servicos/selo_casa_azul>. Acesso em $01 \mathrm{dez} .14$.

CASA \& CONSTRUÇÃO. Telhado de fibra ecológica. Disponível em: <http://www.cec.com.br/dicas-sustentabilidade-telhado-de-fibra-ecologica?id=336>. Acesso em 06 out. 14.

CASA.COM.BR. Casa sustentável: com painéis de OSB e fachada de madeira plástica. Disponível em: <http://casa.abril.com.br/materia/casa-sustentavel-osb-madeira-plastica\#1>. Acesso em 22 set. 14.

CICLOVIVO. Empresa mostra como é o processo de produção de telhas ecológicas. Disponível em: <http://www.ciclovivo.com.br/noticia/empresa_mostra_como_e_o_pro cesso_de_producao_de_telhas_ecologicas>. Acesso em 06 out. 14.

CLARO, Anderson. Tecnologia de Edificação I. Universidade Federal de Santa Catarina. Curso de Arquitetura e Urbanismo. Disponível em: $<$ http://www.arq.ufsc.br/arq5661/trabalhos_2006-

1/teto_jardim/vantagens_e_desvantagens.htm>. Acesso em 21 jun. 13.

CLIQUE ARQUITETURA. Telhas ecológicas. Disponível em: <http://www.cliquearquitetura.com.br/portal/dicas/view/telhas-ecologicas/193>. Acesso em 06 out. 14.

COMCIÊNCIA. Sustentabilidade na construção civil: benefícios ambientais e econômicos. Revista eletrônica de Jornalismo científico. Disponível em: $<$ http://www.comciencia.br/comciencia/?section=8\&edicao=60\&id=755>. Acesso em 25 ago. 14

COMISSÃO NACIONAL DOS TRABALHADORES DO AMIANTO. Disponível em: <http://www.cnta.org.br>. Acesso em 16 out. 2015.

CONSELHO DE ARQUITETURA E URBANISMO DO BRASIL. Disponível em: <htpp//www.caubr.gov.br>. Acesso em 27 out. 2015.

CONSTRUÇÃO. Telhas de concreto $\mathbf{X}$ telhas cerâmicas. Disponível em: $<$ http://construcaomercado.pini.com.br/negocios-incorporacao-construcao/127/artigo2997061.aspx>. Acesso em 17 out. 15. 
CONSTRUIR SUSTENTÁVEL. Alimentos vindos direto do telhado em restaurante americano. Disponível em: <http://www.construirsustentavel.com.br/greenbuilding/583/alimentos-vindos-direto-do-telhado-em-restaurante-americano\#ixzz3qtjSaVJO>. Acesso em 21 jun. 2013

CRIAR ARQUITETURA SUSTENTÁVEL. Disponível em: $<$ http://www.criaarquiteturasustentavel.com.br/lista-de-materiais-ecologicos.html>. Acesso em 25 set. 14 .

CULTURA MIX. Disponível em: <http//www.meioambiente.culturamix.com>. Acesso em 07 out. 2014.

DIAS, C.M.R., CINCOTTO, M.A., SAVASTANO JR., H., JOHN, V.M. Envelhecimento de longo prazo de telhas onduladas de fibrocimento - o efeito da carbonatação, lixiviação e chuva ácida. Disponível em: <http://www.crisotilabrasil.org.br/site/uploads/Envelhecimen to\%20de\%20longo.pdf $>$. Acesso em 15 out. 15.

Disponível em: <htpp//file://C:/Users/Windows/Downloads/FOLLETO_BREEAM PTV3.pdf $>$. Acesso em 06 out. 14.

Disponível em: <http://www.clestra.com/pt/breeam.html〉. Acesso em 06 out. 14.

DISTEL TELHAS. Disponível em: <htpp//www.disteltelhas.com.br>. Acesso em 15 out. 2015.

EA ENGENHARIA E ARQUITETURA. A viabilidade da certificação de habitações unifamiliares. Disponível em: <http://www.engenhariaearquitetura.com.br/noticias/775/Aviabilidade-da-certificacao-de-habitacoes-unifamiliares.aspx>. Acesso em 10 dez. 14.

EBAH. Tintas naturais. Disponível em: <http://www.ebah.com.br/content/ABAAAAMmo AD/tintas-naturais>. Acesso em 22 set. 14.

ECOCASA. Conheça as soluções para construção sustentável da EcoCasa. Disponível em: $<$ http://www.ecocasa.com.br/solucoes-para-construcao-sustentavel-da-ecocasa.asp>. Acesso em 20 set. 14.

ECOD. EcoD básico: urbanismo sustentável. Disponível em: <http://www.ecodesenvolvimento.org/noticias/ecod-basico-urbanismo-sustentavel>. Disponível em 18 set. 14.

ECOD. Tire suas dúvidas sobre o uso do bambu na construção. Disponível em: $<$ http://www.ecodesenvolvimento.org/posts/2011/abril/tire-suas-duvidas-sobre-o-uso-dobambu-na>. Acesso em 22 set. 14. 
ECOEFICIENTES. Telhas de caixas de leite. Disponível em: $<$ http://www.ecoeficientes.com.br/telhas-de-caixas-de-leite/>. Acesso em 01 out. 14.

ECOPEX. Telha ecológica tetra pak. Disponível em: <http://www.ecopex.com.br/telhas-eplacas/telha-ecologica-tetra-pak/>. Acesso em 02 out. 14.

ECOPRESERVE. Telha ecológica. Disponível em: <http://www.telhaecologica.net/enviar.php>. Acesso em 27 set. 14.

ECOTELHADO. <http://ecotelhado.blog.br/index.php/tag/telhado-verde/>. Acesso em 17 jun. 13.

ECOTELHADO. Disponível em: <http://www.ecotelhado.com.br/Por/ecotelhado>. Acesso em 13 jun. 13

ETERNIT. Quais são as vantagens de usar telhas de fibrocimento? Disponível em: $<$ http://blogdaeternit.com.br/construcao-civil/quais-sao-as-vantagens-de-usar-telhas-defibrocimento/>. Acesso em 17 out. 15.

FAZ FACIL. REFORMA \& CONSTRUÇÃO. Telhas de concreto! Disponível em: <http://www.fazfacil.com.br/reforma-construcao/telhas-de-concreto/>. Acesso em 17 out. 15.

FAZFACIL. Telhas fotovoltaicas ou telhas solares. Disponível em: $<$ http://www.fazfacil.com.br/reforma-construcao/telhas-fotovoltaicas-solares/>. Acesso em 25 set. 14 .

FIBROCIMENTO. Disponível em: <http://www.sinaprocim.org.br/Upload/Esp_Tecn/fibro cimento.pdf $>$. Acesso em 15 out. 15.

FORUM DA CONSTRUÇÃO. Disponível em: <htpp//www.forumdaconstrucao.com.br>. Acesso em 27 jan. 2015.

GARANTE PAULISTANA. Coberturas como aliadas a sustentabilidade, conforto e estética predial. Disponível em: <http://www.garantepaulistana.com.br/noticias/coberturascomo-aliadas-a-sustentabilidade-conforto-e-estetica-predial>. Acesso em 03 fev. 15.

GBC BRASIL. Certificação LEED. Disponível em: <http://www.gbcbrasil.org.br/sobrecertificado.php>. Acesso em 17 nov. 14. 
GBC BRASIL. LEED para novas construções 2009. Registro projeto checklist. Disponível em: <http://gbcbrasil.org.br/sistema/certificacao/CheckListLEEDNCv.3Portugues.pdf>. Acesso em 17 nov. 14.

GLOBO.COM. Revista Época. Disponível em: $<$ http://revistaepoca.globo.com/Revista/Epoca/0,EDG81177-6010-505,00.html>. Acesso em 23 jun. 13.

HYPENESS. Telhado sustentável: conheça as telhas que produzem energia solar. Disponível em: $\quad<$ http://www.hypeness.com.br/2013/03/telhado-sustentavel-conheca-as-telhas-queproduzem-energia-solar/>. Acessoem 25 set. 14.

IDHEA. Construções sustentáveis: uma casa conceito em Curitiba. Disponível em: <http://www.idhea.com.br/pdf/casa_curitiba.pdf>. Acesso em 15 out. 15.

IDHEA. Telhado verde. Disponível em: <http://www.idhea.com.br/produtos/pdf/ TelhadoVerde.pdf>. Acesso em 22 jun. 13

INMETRO. Disponível em: <http://www.inmetro.gov.br/> Acesso em 04 dez. 14.

INOVATECH ENGENHARIA. Disponível em: <http://www.inovatechengenharia.com.br/certificacoes/>. Acesso em $10 \mathrm{dez} .14$.

INSTITUTO DE MEIO AMBIENTE E RECURSOS HIDRÍCOS. Estudo de Impacto Ambiental - EIA. Disponível em: <htpp//www.inema.ba.gov.br〉. Acesso em 27 out. 2015.

KSA MATERIAIS DE CONSTRUÇÃO. Telhados ecológicos: transformando sustentabilidade em economia e design. Disponível em: <http://www.telhado ecologico.com.br/?gclid=CJT19If6tMMCFRSGfgod_bcApQ>. Acesso em 27 jan. 15.

LIVEGREEN. Bem vindo - vamos conhecer mais sobre a madeira plástica. Disponível em: <http://www.madeiraplastica.ws/>. Acesso em 22 set. 14.

LUGAR CERTO. A sustentabilidade na construção civil. Disponível em: <http://www.precisao.eng.br/fmnresp/sustenta.htm>. Acesso em 28 ago. 14.

MASSA CINZENTA. Telhas de concreto. Disponível em: <http://www.cimentoitambe.com.br/telhas-de-concreto/>. Acesso em 17 out. 15. 
MINISTÉRIO DO MEIO AMBIENTE. Construção Sustentável. Disponível em: $<$ http://www.mma.gov.br/cidades-sustentaveis/urbanismo-sustentavel/constru\%C3\%A7\%C3 $\%$ A3o-sustent\%C3\%A1vel>. Acesso em 17 set. 14.

NIVAL COBERTURAS. Disponível em: <http://www.nivalcoberturas.com.br>. Acesso em 17 out. 15.

PALLADIO ARQUITETO. Sustentabilidade desde a Idade Média. Disponível em: <http://palladioarquiteto.blogspot.com.br/2009/01/sustentabilidade-desde-idade-mdia.html>. Acesso em 28 ago. 14.

PBE EDIFICA. Disponível em: 〈http://www.pbeedifica.com.br>. Acesso em 04 dez. 14.

PLANETA SUSTENTÁVEL. Disponível em: 〈htpp//www.planetasustentavel.cbril.com.br〉. Acesso em 15 out. 2015.

PONTIFÍCIA UNIVERSIDADE CATÓLICA DE SÃO PAULO. BISUS Boletim de Inovação e Sustentabilidade. Disponível em: <http://www.pucsp.br/sites/default/files/download/posgra duacao/programas/administracao/bisus/bisus_1_2013/2013_volume1.pdf $>$. Acesso em 25 out. 15.

PONTIFÍCIA UNIVERSIDADE CATÓLICA DO RIO DE JANEIRO. Disponível em: <http://www.pucrio.br/pibic/relatorio_resumo2008/relatorios/ctch/art/art_lauravg.pdf>.

Acesso em 20 jun. 2013.

PORTAL DO MEIO AMBIENTE. Disponível em: <htpp//www.portal.rebia.org.br>. Acesso em 27 out. 2015.

PORTAL DO MEIO AMBIENTE. Embalagens Tetra Pak recicladas se transformam em telhas ecologicamente corretas. Disponível em: <http://www.portaldomeio ambiente.org.br/lixo-e-reciclagem/3104-embalagens-tetra-pak-recicladas-se-transformam-emtelhas-ecologicamente-corretas>. Acesso em 27 set. 14.

PROCEL INFO. Disponível em: <http://www.procelinfo.com.br/>. Acesso em 04 dez. 14.

QUADLOCK. Disponível em: <http://www.quadlock.com/images/decking/ICF_Green _Roof.jpg>. Acesso em 21 jun. 13.

RIO - 92. Disponível em <htpp://www.senado.gov.br>. Acesso em 04 dez. 14. 
SCIELO. Certificação ambiental de habitações: comparação entre LEED for homes, Processo Aqua e Selo Casa Azul. Disponível em: 〈http://www.scielo.br/pdf/asoc/v17n2/a13v17n2.pdf〉. Acesso em 25 nov. 14.

SILVA, Vanessa Gomes da; SILVA, Maristela Gomes da; AGOPYAN, Vahan. Avaliação de edifícios no Brasil: da avaliação ambiental para avaliação de sustentabilidade. Ambiente Construído, Porto Alegre, v. 3, n. 3, p. 7-18, jul./set. 2003. Disponível em: <http://www.seer.ufrgs.br/ambienteconstruido/article/viewFile/3491/1892>. Acesso em 22 out. 15 (Avaliação de edifícios no Brasil: da avaliação ambiental para avaliação de sustentabilidade)

STORMWATER. Disponível em: <http://www.lid-stormwater.net/images/greenroof1.jpg>. Acesso em 21 jun. 13.

TACASAS. Telhados verdes estão se transformando em espaços habitáveis. Disponível em: $<$ http://www.tacasas.com.br/2012/06/14/telhados-verdes-estao-se-transformando-em-espacoshabitaveis/>. Acesso em 20 jun. 13.

TEGULA SOLUÇÕES PARA TELHADOS. Disponível em: <http://www.tegula.com.br>. Acesso em 17 out. 15.

TELHADO VERDE. Controle de praga. Disponível em: <http://controledepraga.com.br/layout/lvl/telhado\%20verde>. Acesso em 17 jun. 13.

TOMAZ, Plinio. Cobertura verde. Curso de manejo de aguas pluviais. Disponível em: <http://www.pliniotomaz.com.br/downloads/capitulo51_telhado_verde.pdf >. Acesso em 20 jun. 13.

UOL ESTILO. Colocar telhas de fibrocimento sobre a laje esquenta a casa? Disponível em: $<$ http://casaeimoveis.uol.com.br/tire-suas-duvidas/arquitetura/colocar-telhas-de-fibrocimentosobre-a-laje-esquenta-a-casa.jhtm>. Acesso em 17 out. 15.

VASATEX. Disponível em: <http://www.ceramicavasatex.com.br/?go=produtos>. Acesso em 28 jan. 15. 